PAULO FERNANDO ALMEIDA BRAGA

\title{
CARACTERIZAÇÃO E BENEFICIAMENTO DA MOLIBDENITA DA REGIÃO DE CAMPO FORMOSO - BA
}

\author{
Tese apresentada à Escola Politécnica da \\ Universidade de São Paulo para obtenção \\ do Título de Doutor em Engenharia.
}

São Paulo

2013 
PAULO FERNANDO ALMEIDA BRAGA

\title{
CARACTERIZAÇÃO E BENEFICIAMENTO DA MOLIBDENITA DA REGIÃO DE CAMPO FORMOSO - BA
}

\author{
Tese apresentada à Escola Politécnica da \\ Universidade de São Paulo para obtenção \\ do Título de Doutor em Engenharia \\ Área de Concentração: \\ Engenharia Mineral
}

Orientador:

Prof. Dr. Arthur Pinto Chaves

São Paulo

2013 
Este exemplar foi revisado e corrigido em relação à versão original, sob responsabilidade única do autor e com a anuência de seu orientador.

São Paulo, de junho de 2013.

Assinatura do autor

Assinatura do orientador

FICHA CATALOGRÁFICA

Braga, Paulo Fernando Almeida

Caracterização e beneficiamento da molibdenita da região de Campo Formoso-BA / P.F.A. Braga. -- versão corr. --São Paulo, 2013.

$147 \mathrm{p}$.

Tese (Doutorado) - Escola Politécnica da Universidade de São Paulo. Departamento de Engenharia de Minas e de Petróleo.

1.Caracterização tecnológica de minérios - Campo Formoso (BA) 2.Processamento mineral - Campo Formoso (BA)

3.Molibdenita I.Universidade de São Paulo. Escola Politécnica. Departamento de Engenharia de Minas e de Petróleo II.t. 
Para Ursula e Geovana com o carinho do papi. 


\section{AGRADECIMENTOS}

Ao Prof. Arthur Pinto Chaves, pela orientação da pesquisa e leitura crítica do texto e a confiança depositada ao me aceitar como seu orientando.

Ao Dr Adão Benvindo da Luz, co-orientador e idealizador deste projeto, sempre objetivo nos seus comentários.

A Dra Sílvia França pelo apoio, incentivo e disposição para discutir os resultados obtidos, bem como, pela visão crítica deste trabalho, também uma coorientadora.

Ao grande Técnico Tiago Teotônio, meu braço direito, em todas as etapas desta jornada.

A Márcia Moura, brilhante secretária, pela paciência, presteza e educação na ajuda para resolver pequenos e grandes problemas.

A Natasha Li pela editoração, revisão, diagramação e pesquisa de parte desta tese.

Ao Dr João Sampaio, grande crítico, porém vibrante com os resultados alcançados.

A direção do CETEM, pela infraestrutura disponibilizada, bem como, pela liberação para conclusão desta tese.

Ao colega Reiner Neumann pela ajuda na caracterização mineralógica dos minerais estudados.

A Dra Marisa Monte, Juan Guerrero e Débora Sanches pelas medidas de ângulo de contato, determinação do potencial zeta e determinação do peso molecular de polímeros no Laboratório de Química de Superfície do CETEM.

Aos colegas da COAM, Arnaldo, Nelma (in memorian), Gaspar, Sandra, Antonieta, Thais, Jaqueline e Josimar pelas análises químicas e minerais diversas contidas nesta tese.

Ao Tio Zé e ao Sr Moisés pela cessão de amostras de molibdenita e minérios da região de Pindobaçu, Bahia, necessárias ao desenvolvimento desta pesquisa.

A todos que de alguma forma contribuíram para realização deste trabalho e, que por ventura, tenha esquecido de citar, o meu muito obrigado. 


\section{RESUMO}

Neste trabalho foram abordados aspectos da cadeia do molibdênio e da molibdenita nos mercados internacional e nacional, mostrando as ocorrências e suas principais aplicações. Atualmente, no Brasil, a única opção de aproveitamento econômico desse bem mineral é o minério de molibdenita gerado como coproduto ou subproduto da mineração artesanal de esmeraldas, na região de Campo Formoso e Pindobaçu, BA.

A caracterização tecnológica de minérios, produtos e do processo utilizado na recuperação da molibdenita de Campo Formoso mostrou que entraves de natureza tecnológica, com destaque relacionado ao concentrado produzido, geram produtos de baixo teor e, consequentemente, de pequeno valor econômico. Isto é devido, principalmente, à presença de outros minerais hidrofóbicos, como o talco, com propriedades físico-químicas semelhantes às da molibdenita e que são co-flotados no processo de beneficiamento.

Detectado o problema, e após uma revisão bibliográfica sobre o assunto, realizou-se um estudo fundamental, em escala de laboratório, sobre a separação molibdenita/talco por flotação, com a utilização de diferentes depressores empregados, usualmente, em operações de tratamento de minérios. Dentre os depressores utilizados, a dextrina e o quebracho promoveram janelas de separabilidade entre os minerais molibdenita e talco de 63 e $68 \%$, respectivamente.

Os resultados alcançados nesses estudos fundamentais motivaram um aumento de escala, passando dos testes de microflotação em célula Partridge \& Smith, para testes de flotação em bancada em célula Denver, com as dosagens dos reagentes calculadas em termos de gramas de reagente por tonelada de alimentação à flotação (concentrado de molibdenita).

$\mathrm{Na}$ flotação em escala de bancada, os melhores resultados foram obtidos com uso da dextrina como depressor da molibdenita, na dosagem de $100 \mathrm{~g} / \mathrm{t}$, para um circuito com cinco etapas de limpeza, foi possível obter um concentrado de molibdenita com $93,4 \%$ de $\mathrm{MoS}_{2}$, o qual encontra-se dentro dos requisitos exigidos pelo comércio internacional. 


\begin{abstract}
In this scientific and technological contribution, the aspects of the molybdenum and molybdenite chain in the domestic and international markets were discussed, showing the occurrences and their main applications. Currently, in Brazil the only option for the economic exploitation of this mineral resource is the molybdenite as a co-product or by-product of emeralds small-scale mining, at the region of Campo Formoso and Pindobaçu, BA.

The technological characterization of ores, products and the process used in the recovery of molybdenite from Campo Formoso has shown that barriers of technological nature, with emphasis on the produced concentrate, generate products of low molybdenite grade and, therefore, of low economic value. This is due to the presence, in particular, of other hydrophobic minerals, such as talc, with physicalchemical properties similar to those of molybdenite and are co-floated in the beneficiation process.

Once detected the problem, and after an extensive literature survey on the subject, a fundamental study was carried out, in lab-scale, to separate molybdenite from talc by froth flotation, by testing different depressants conventionally used in actual mineral processing operations. Among the tested depressants, dextrin and quebracho promoted separation gaps between the molybdenite and talc minerals of 63 and $68 \%$, respectively.

The achieved results in that fundamental study has motivated an scale up from micro-flotation tests, in Partridge \& Smith cell, to bench scale flotation tests in a Denver cell, reagents additions were calculated according to the ore (molybdenite concentrate) throughput into the industrial flotation circuits.

In the bench scale flotation tests, the best results, in terms of molybdenite recovery, were reached by using dextrin as molybdenite depressant, at a dosage of $100 \mathrm{~g} .^{-1}$, for a circuit with five cleaner steps. It was possible to get a molybdenite concentrate with $93.4 \%$ of $\mathrm{MoS}_{2}$, which is within the requirements of the international trade.
\end{abstract}




\section{LISTA DE FIGURAS}

Figura 1.1 - Balança comercial para o molibdênio brasileiro ............................................18

Figura 4.1 - Molibdenita encaixada em micaxisto da Serra de Carnaíba ...........................26

Figura 4.2 - Reservas Mundiais de Molibdênio........................................................27

Figura 4.3 - Produção mundial de molibdênio no ano de 2011 .....................................28

Figura 4.4 - Distribuição setorial das principais aplicações do molibdênio ..........................30

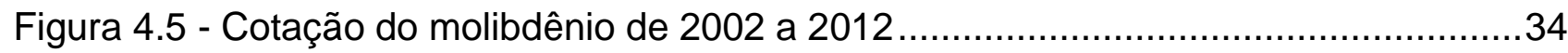

Figura 4.6 - Curvas de oferta e demanda mundiais do molibdênio ...................................35

Figura 4.7 - Diagrama de blocos da cadeia produtiva do molibdênio (processos e

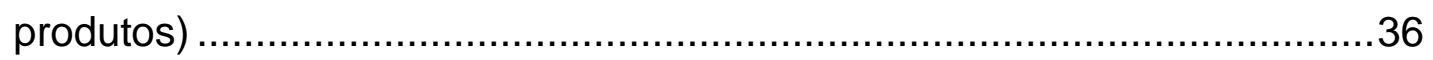

Figura 4.8 - Circuito de Flotação do molibdênio em Chuquicamata, Chile ........................38

Figura 4.9 - Química do molibdênio e seus compostos ...............................................42

Figura 4.10 - Importação de produtos de molibdênio no ano de 2011 ..............................43

Figura 4.11 - Quantidade e preço de importação de molibdenita ustulada .........................45

Figura 4.12 - Mapa de Localização dos Garimpos na Serra de Carnaíba, BA ....................48

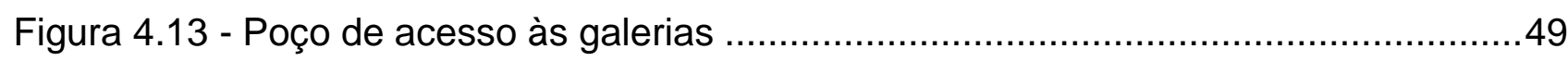

Figura 4.14 - Catação manual de molibdenita em garimpos da Serra de Carnaíba ............49

Figura 4.15 - Britador de mandíbulas (A); Moinho de martelos (B); Células de flotação

(C); Processo de flotação (D) ............................................................50

Figura 4.16 - Fluxograma de beneficiamento utilizado na recuperação de molibdenita

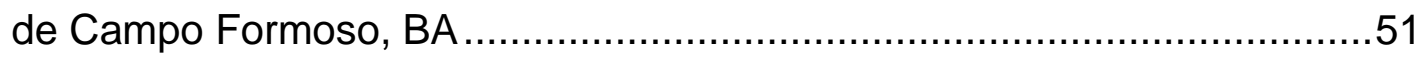

Figura 4.17 - Imagem de MEV da molibdenita intercrescida com clorita e flogopita ..........51

Figura 4.18 - Fluxograma geral da Pima Mining (adaptado de PARKINSON, 1976)..........55

Figura 4.19 - Fluxograma utilizado pela Anaconda Co. (circuito aberto e fechado) ............57

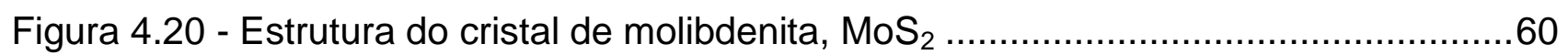

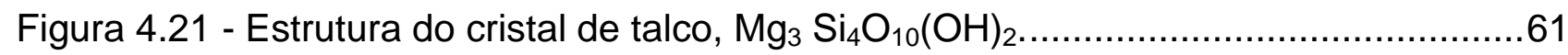

Figura 4.22 - Classificação dos reagentes modificadores .................................................65

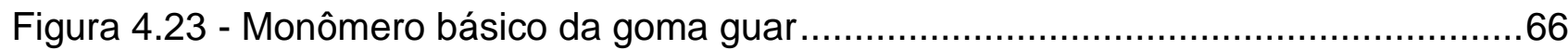

Figura 4.24 - Monômero básico do amido e da dextrina ...............................................68

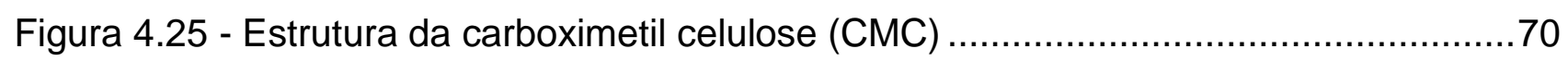

Figura 4.26 - Efeito da concentração de ácido húmico e do pH na recuperação da molibdenita (adaptada de LAI; STONE; RIMMSCH, 1984) ........................72

Figura 4.27 - Estruturas da amilose e da amilopectina.................................................74 
Figura 4.28 - Efeito do tipo de amido na recuperação de chumbo em concentrados rougher de cobre (adaptado de BULATOVIC; 1999) ..............................75

Figura 4.29 - Estrutura aproximada do quebracho, $n=1-200$ (PEARSE, 2005) ...............76

Figura 5.1 - Diagrama em blocos do processo de preparação das amostras ...................80

Figura 5.2 - Sistema de flotação com célula Partridge \& Smith......................................86

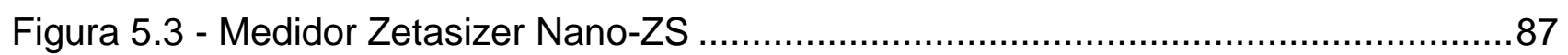

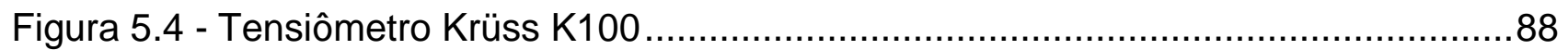

Figura 5.5 - Diagrama do processo de flotação em bancada ...................................93

Figura 6.1 - Difratograma de raios-X do minério (ROM) GP ......................................96

Figura 6.2 - Difratograma de raios-X do minério (ROM) GM ....................................96

Figura 6.3 - Difratograma de raios-X do minério (ROM) GF .................................97

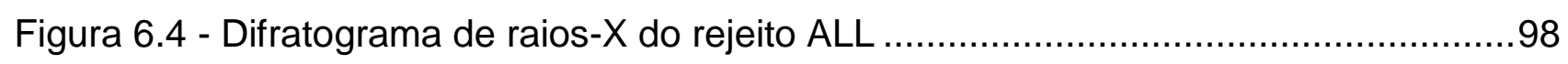

Figura 6.5 - Distribuição granulométrica dos rejeitos de flotação ALL, TZ e SE ...............99

Figura 6.6 - Imagem de MEV da amostra do concentrado de molibdenita afundado no bromofórmio ................................................................................. 100

Figura 6.7 - DRX da amostra da molibdenita afundada no bromofórmio.......................101

Figura 6.8 - Imagem de MEV dos minerais de ganga flutuados em bromofórmio ............102

Figura 6.9 - DRX da amostra dos minerais de ganga flutuados em bromofórmio ............102

Figura 6.10 - Curva de DTA/TG do concentrado de molibdenita.................................104

Figura 6.11 - Curva de distribuição granulométrica da alimentação e dos produtos ........105

Figura 6.13 - Imagem de MEV da amostra de talco ................................................106

Figura 6-14 - Distribuição granulométrica das amostras de molibdenita e talco..............107

Figura 6-15 - Cinética de flotação da molibdenita e do talco para um tempo de $240 \mathrm{~s}$....108

Figura 6-16 - Flotabilidade em função do tamanho da partícula..................................109

Figura 6-17 - Influência do pH na flotabilidade natural da molibdenita e do talco............110

Figura 6-18 - Diagrama de Pourbaix para o molibdênio (adaptada de CHANDER;

FUERSTENAU, 1972) ................................................................. 112

Figura 6-19. - Imagens de MFA em diferentes áreas da face da molibdenita nos tamanhos 10x10, 6X6, 5x5 e 2x2 um (LÓPEZ-VALDIVIESO et al., 2012) 113

Figura 6-20 - Influência do pH na flotabilidade da molibdenita e do talco na presença de

CMC

Figura 6-21 - Influência do pH na flotabilidade da molibdenita e do talco na presença de goma guar 
Figura 6-22 - Influência do pH na flotabilidade da molibdenita e do talco na presença de amido

Figura 6-23 - Influência do pH na flotabilidade da molibdenita e do talco na presença de ácido húmico

Figura 6-24 - Influência do pH na flotabilidade da molibdenita e do talco na presença de silicato de sódio 118

Figura 6-25 - Influência do pH na flotabilidade da molibdenita e do talco na presença de dextrina

Figura 6-26 - Flotabilidade da molibdenita e do talco em diferentes concentrações de dextrina e $\mathrm{pH} 8$

Figura 6-27 - Curva de potencial zeta da molibdenita com e sem dextrina 121

Figura 6-28 - Curva de potencial zeta do talco com e sem dextrina 121

Figura 6-29 - Influência do pH na flotabilidade da molibdenita e do talco na presença de quebracho

Figura 6-30 - Flotabilidade da molibdenita e do talco em diferentes concentrações de quebracho a $\mathrm{pH} 8$

Figura 6-31 - Curva de potencial zeta da molibdenita com e sem quebracho 124

Figura 6-32 - Curva de potencial zeta do talco com e sem quebracho. 124

Figura 6-33 - Ângulos de contato da molibdenita condicionada em diferentes concentrações de dextrina.

Figura 6-34 - Ângulos de contato da molibdenita condicionada em diferentes concentrações de quebracho

Figura 6-35 - Determinação do peso molecular da dextrina 128

Figura 6-36 - Determinação do peso molecular do quebracho 129

Figura 6-37 - Distribuição granulométrica do concentrado de molibdenita. 130

Figura 6-38 - Flotação em bancada, célula Denver D12 131

Figura 6-39 - Teor do concentrado final de molibdenita com diferentes dosagens de dextrina

Figura 6-40 - Teor dos principais contaminantes nos concentrados de molibdenita com diferentes dosagens de dextrina 132

Figura 6-41 - Curva de purificação da molibdenita por lixiviação com HF (5\% p/v) 133 


\section{LISTA DE TABELAS}

Tabela 4.1 - Propriedades físicas e químicas dos minerais de molibdênio .........................26

Tabela 4.2 - Empresas produtoras de molibdênio primário e suas minas .........................28

Tabela 4.3 - Empresas produtoras de molibdênio como coproduto e suas minas .............29

Tabela 4.4 - NCM dos produtos de molibdênio comercializados mundialmente .................33

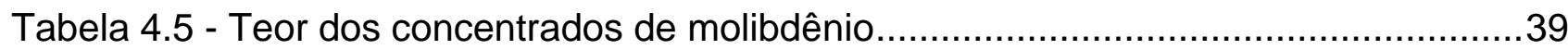

Tabela 4.6 - Especificações químicas e físicas do bissulfeto de molibdênio ........................40

Tabela 4.7 - Composição química (\%) do ferromolibdênio ..................................................41

Tabela 4.8 - Importação brasileira de produtos de molibdênio ........................................44

Tabela 4.9 - Importações de bens primários, semimanufaturados, manufaturados e

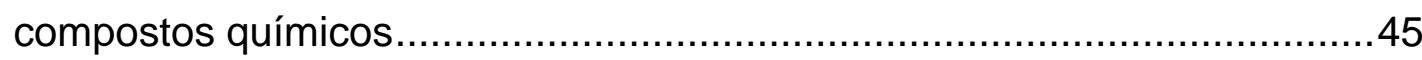

Tabela 4.10 - Balanço de massa e metalúrgico do processo da Pima Mine ......................56

Tabela 4.11 - Teores da alimentação, dos concentrados e recuperação metalúrgica do

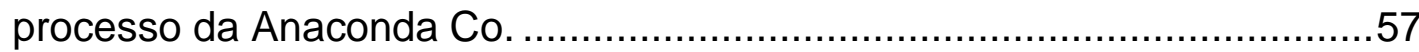

Tabela 4.12 - Propriedades de sólidos hidrofóbicos (molibdenita e talco) ..........................63

Tabela 4.13 - Recuperação de molibdenita em função da concentração de dextrina ........68

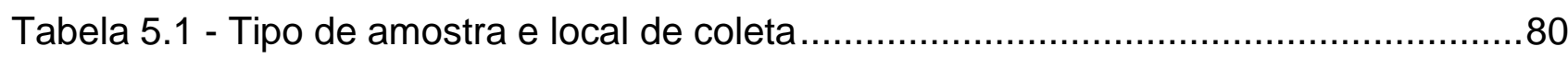

Tabela 5.2 - Condições operacionais do processo de flotação em bancada .......................83

Tabela 5.3 - Reagentes utilizados no processo e suas funções ........................................8

Tabela 5.4 - Condições operacionais do processo de flotação em bancada .......................93

Tabela 6.1 - Análise química de minérios de Campo Formoso ……...............................95

Tabela 6.2 - Liberação da molibdenita em relação aos minerais de ganga .........................97

Tabela 6.3 - Análise química dos rejeitos da flotação ..................................................98

Tabela 6.4 - Análise química dos concentrados de molibdenita .......................................99

Tabela 6.5 - Análise química do concentrado de talco ……........................................107

Tabela 6.6 - Área superficial específica das partículas de molibdenita e talco.................109

Tabela 6.7 - Ângulo de contato e constante de capilaridade dos minerais molibdenita e

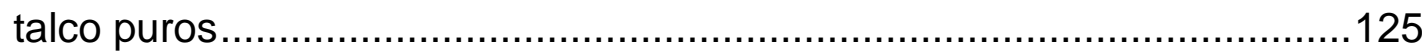

Tabela 6.8 - Análise química do concentrado de molibdenita (alimentação da flotação) 130 Tabela 6.9 - Análise química do concentrado de molibdenita purificado por flotação ......133

Tabela 6.10 - Análise química do concentrado de molibdenita lixiviado...........................134 


\section{SUMÁRIO}

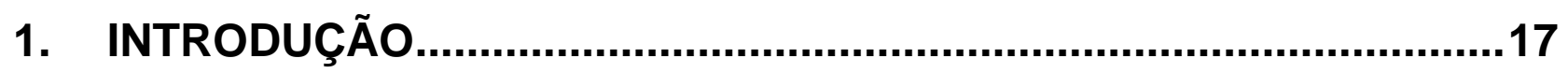

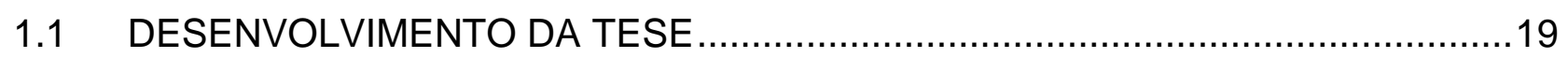

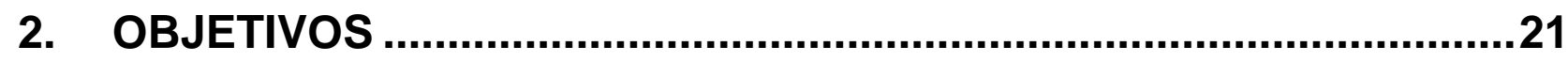

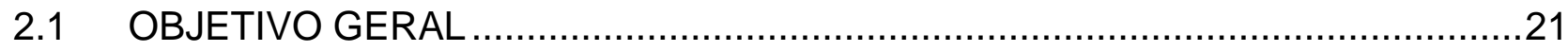

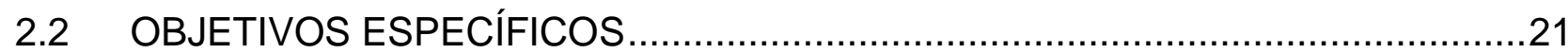

3. INOVAÇÃO TECNOLÓGICA E A FRONTEIRA DO CONHECIMENTO

4. REVISÃO BIBLIOGRÁFICA ........................................................24

4.1 PROPRIEDADES FÍSICAS E QUÍMICAS DO MOLIBDÊNIO ...............................25

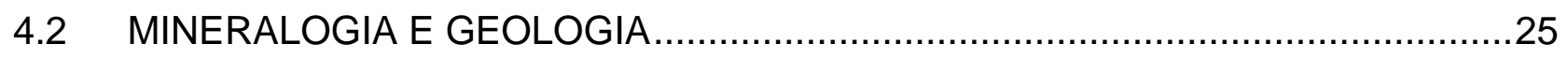

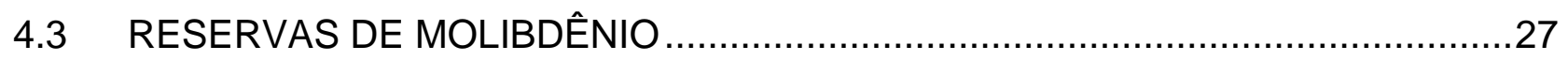

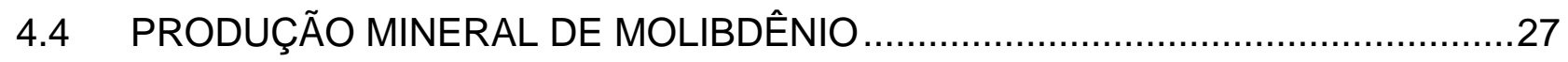

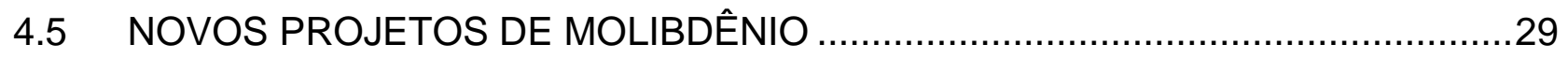

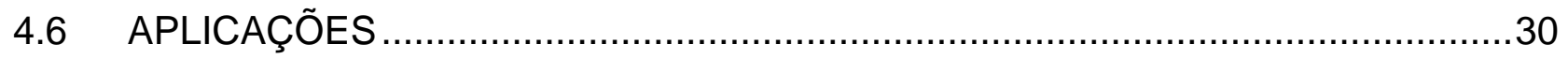

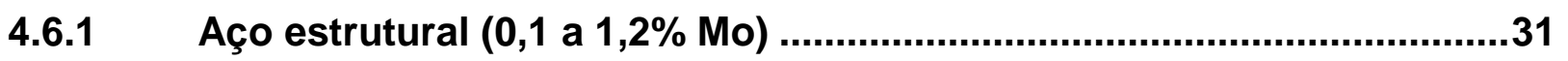

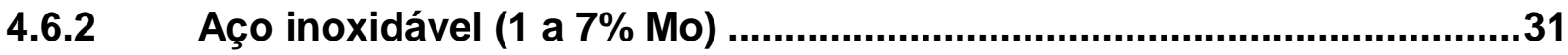

4.6.3 Aço ferramenta e aço rápido (1 a 9\% Mo) ................................................31

4.6.4 Produtos químicos de molibdênio..........................................................32

4.7 PRINCIPAIS PRODUTOS COMERCIALIZADOS DE MOLIBDÊNIO ....................32

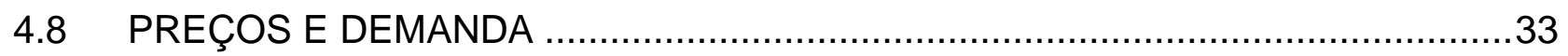

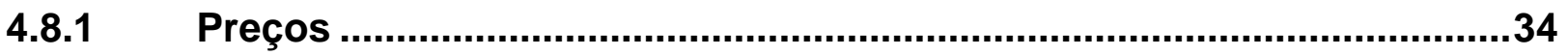

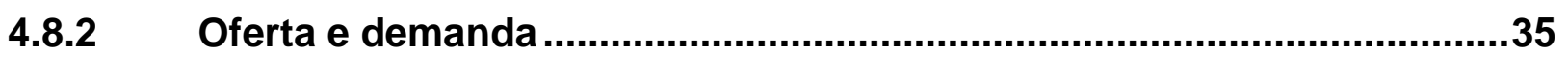

4.9 BENEFICIAMENTO MINERAL, PROCESSOS METALÚRGICOS E

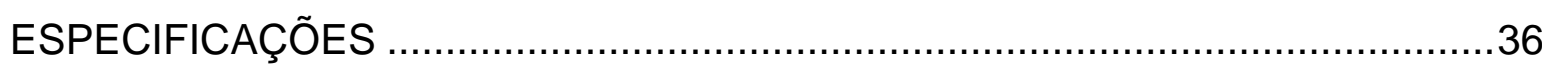

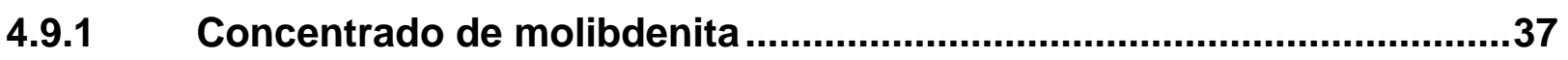

4.9.2 Molibdenita lubrificante .................................................................... 
4.9.3 Óxido de molibdênio técnico …...........................................................40

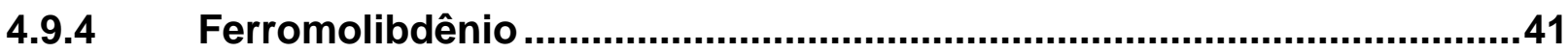

4.9.5 Molibdênio metálico.............................................................................

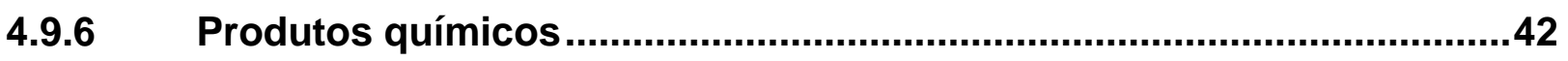

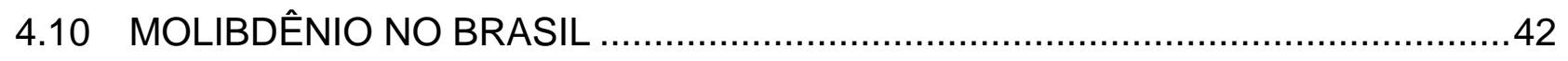

4.10.1 Reservas nacionais .........................................................................

4.10.2 Balança comercial do molibdênio no Brasil ...........................................43

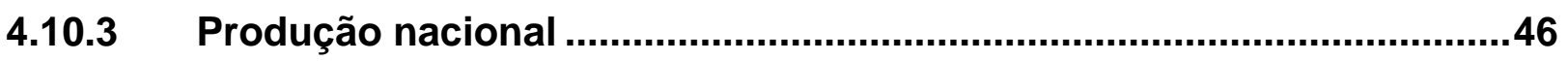

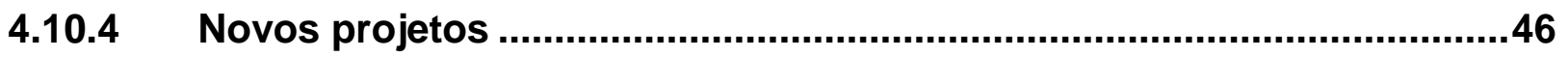

4.10.5 Antecedentes do beneficiamento de molibdenita no Brasil..................46

4.10.6 Condicionantes geológicos da mineralização na Serra da Carnaíba ...47

4.10.7 Lavra e beneficiamento de molibdenita em Campo Formoso................48

4.11 PROCESSOS PARA SEPARAÇÃO MOLIBDENITATTALCO EM

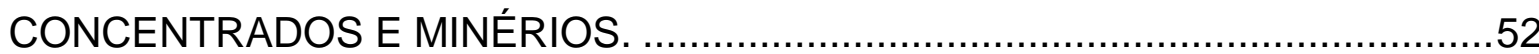

4.11.1 Pima process, separação talco-molibdenita...........................................54

4.11.2 Concentração em separador triboeletrostático .......................................56

4.11.3 Sulfonato de lignina como depressor de molibdenita ............................56

4.12 ESTUDOS FUNDAMENTAIS PARA SEPARAÇÃO DE MOLIBDENITA E

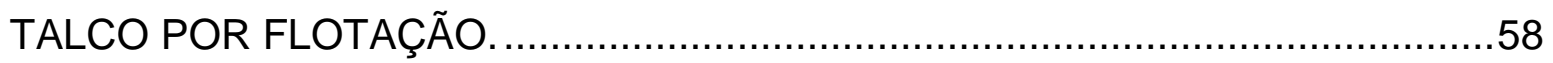

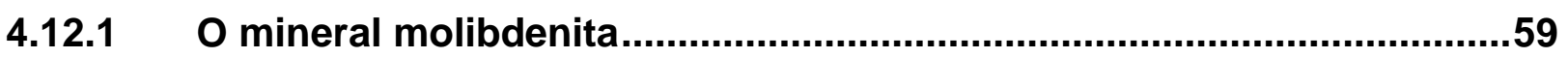

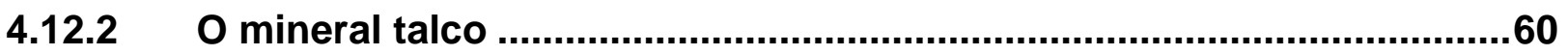

4.12.3 A flotabilidade natural da molibdenita e do talco ...................................61

4.12.4 Reagentes modificadores no processamento mineral ..........................64

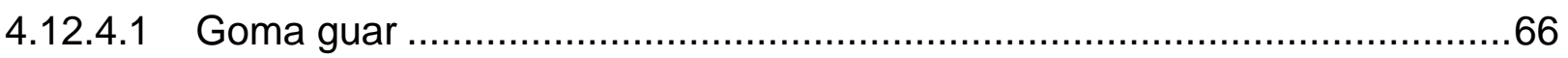

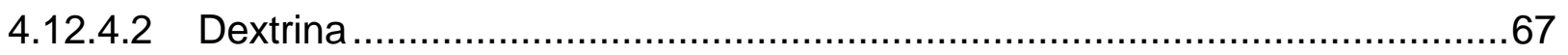

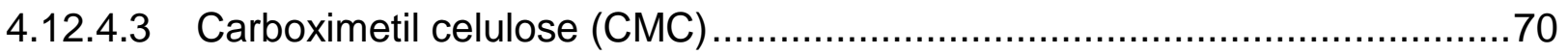

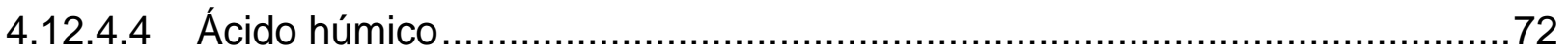

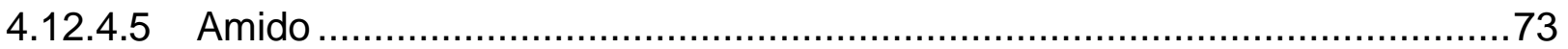




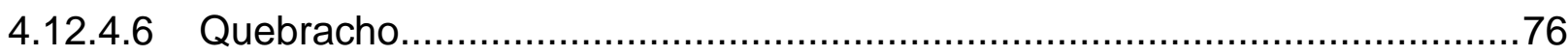

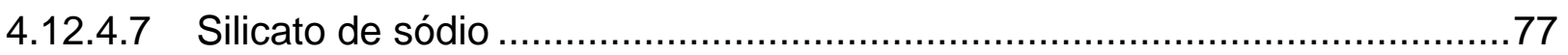

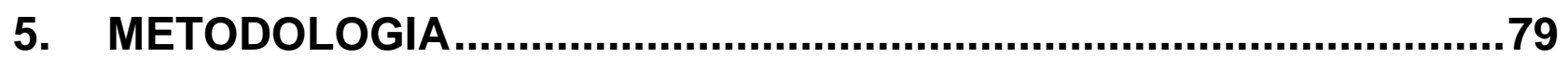

5.1 PROCEDIMENTO EXPERIMENTAL I - CARACTERIZAÇÃO TECNOLÓGICA DE MINÉRIOS, CONCENTRADOS, REJEITOS E DO PROCESSO UTILIZADO

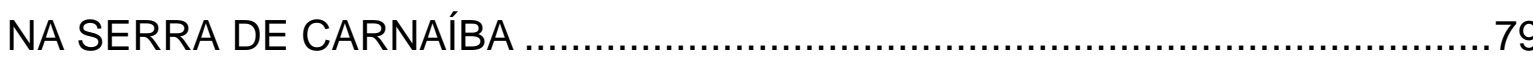

5.1.1 Obtenção e preparação das amostras ..................................................79

5.1.2 Caracterização mineralógica e química ...................................................

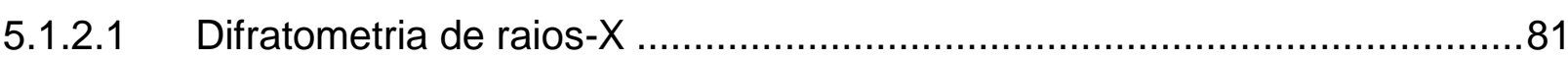

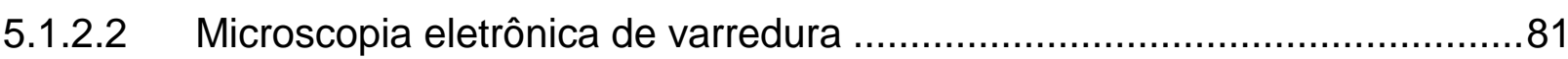

5.1.2.3 Análises químicas .......................................................................... 82

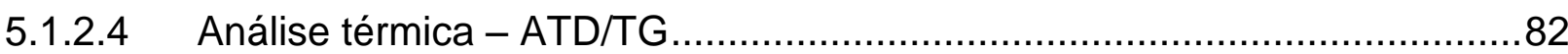

5.1.3 Determinação experimental do "work index" de Bond (WI ...................82

5.1.4 Ensaios de beneficiamento em escala de bancada ..............................82

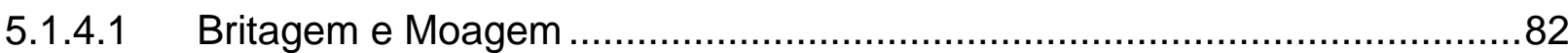

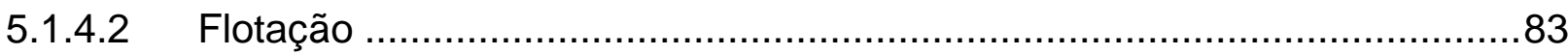

5.2 PROCEDIMENTO EXPERIMENTAL ॥ - ESTUDOS FUNDAMENTAIS DE SEPARABILIDADE DO SISTEMA MOLIBDENITA/TALCO .................................84

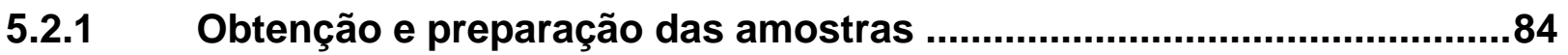

5.2.2 Caracterização mineralógica e química ...................................................84

5.2.2.1 Distribuição do tamanho de partículas ....................................................84

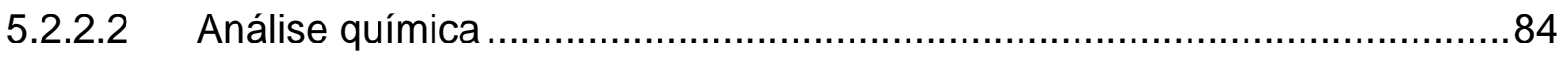

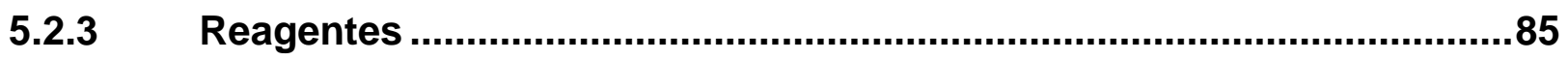

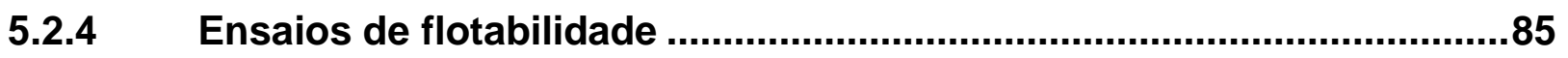

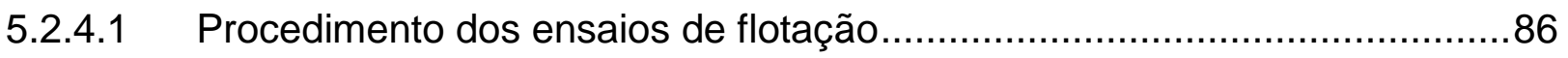

5.2.5 Determinação do potencial zeta..............................................................87

5.2.6 Medida do ângulo de contato pelo método de ascensão capilar..........88

5.2.7 Medida do peso molecular da dextrina e do quebracho..........................89 
5.3 PROCEDIMENTO EXPERIMENTAL III - PURIFICAÇÃO DO CONCENTRADO

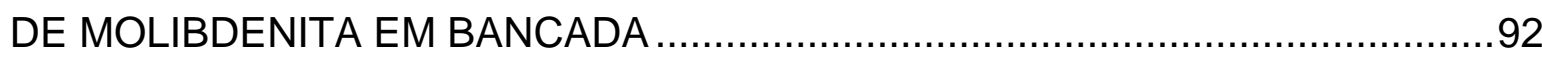

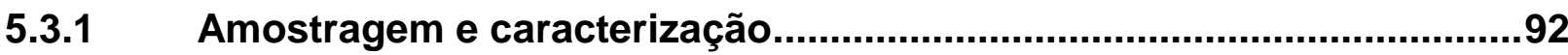

5.3.2 Purificação da molibdenita por flotação ……………..............................92

5.3.3 Purificação do concentrado de molibdenita por lixiviação fluorídrica.94

6. RESULTADOS E DISCUSSÃO......................................................95

6.1 CARACTERIZAÇÃO TECNOLÓGICA DE MINÉRIOS, CONCENTRADOS, REJEITOS E DO PROCESSO UTILIZADO NA SERRA DE CARNAÍBA ..............95

6.1.1 Caracterização Química e Mineralógica ..................................................95

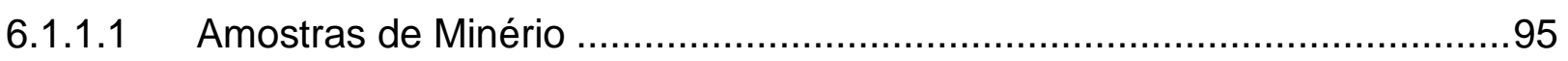

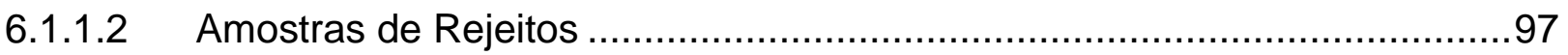

6.1.1.3 Amostras de Concentrados de Molibdenita da Serra de Carnaíba .............99

6.1.1.4 Análise Térmica (DTA/TG) do Concentrado de Molibdenita ....................103

6.1.2 Determinação Experimental do "Work Index" de Bond (WI) ................104

6.1.3 Ensaios Preliminares de Beneficiamento dos Minérios de Molibdênio da Serra de Carnaíba......................................................105

6.1.3.1 Estudos iniciais de concentração …………………………………....105

6.2 ESTUDOS FUNDAMENTAIS DE SEPARABILIDADE DO SISTEMA

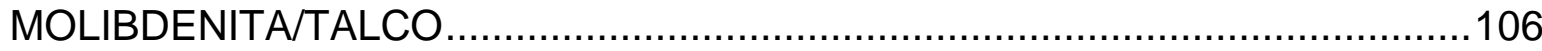

6.2.1 Caracterização Mineralógica e Química da Molibdenita e do Talco ...106

6.2.2 Distribuição de tamanho de partículas e cinética de flotação .............107

6.2.3 Efeito do tamanho de partícula ............................................................108

6.2.4 Ensaios de Flotabilidade da molibdenita e talco em célula Partrigde

\& Smith com variação de $\mathrm{pH}$ e sem agente depressor .........................110

6.2.5 Ensaios de Flotabilidade da molibdenita e talco em célula Partrigde

\& Smith com agente depressor..........................................................113

6.2.6 Medida do Ângulo de Contato pelo Método de Ascensão Capilar .....125

6.2.7 Medida do Peso Molecular ................................................................127 
6.3 PURIFICAÇÃO DO CONCENTRADO DE MOLIBDENITA EM BANCADA 130

6.3.1 Caracterização do concentrado de molibdenita ...................................130

6.3.2 Purificação do concentrado por flotação...............................................131

6.3.3 Purificação do concentrado de molibdenita por lixiviação fluorídrica133

7. CONCLUSÕES...........................................................................135

REFERÊNCIAS BIBLIOGRÁFICAS .....................................................138 


\section{INTRODUÇÃO}

O molibdênio não é encontrado livre na natureza e sua principal fonte é a molibdenita, que é um mineral acessório em certos granitos, pegmatitos e aplitos. Comumente a molibdenita ocorre em depósitos de filões, associada com a cassiterita, scheelita, wolframita e fluorita. Também pode ser encontrada em depósitos metamórficos de contato, com silicatos de cálcio, scheelita e calcopirita. O molibdênio é explotado comercialmente como um sulfeto metálico (molibdenita) em grandes depósitos de molibdênio pórfiro com baixo teor (produção primária) e como um sulfeto metálico associado a depósitos de cobre pórfiro (produção secundária).

O molibdênio é um elemento metálico refratário, usado principalmente como agente em ligas em aço, ferro fundido e superligas para reforçar a temperabilidade, dureza e resistência ao desgaste e à corrosão. Para obter as propriedades metalúrgicas desejadas, o molibdênio, sob a forma de trióxido de molibdênio $\left(\mathrm{MoO}_{3}\right)$ ou de ferromolibdênio ( $\mathrm{FeMo}$ ), é freqüentemente usado em combinação com o cromo, nióbio, manganês, níquel, vanádio e tungstênio, que são metais formadores de ligas. O molibdênio também tem um uso importante na indústria química, incluindo a fabricação de catalisadores, pigmentos e lubrificantes e na agricultura como micronutriente (MERCHANT, 2011).

No ano de 2012, a balança comercial brasileira para a cadeia do molibdênio (bens primários, semimanufaturados e manufaturados e compostos químicos) foi caracterizada por um déficit de aproximadamente US\$162 milhões, sendo quase $50 \%$ com origem na importação de concentrado (SISTEMA ALICE-WEB, 2012). A Figura 1.1 mostra 0 déficit da balança comercial brasileira para a cadeia de molibdênio. 


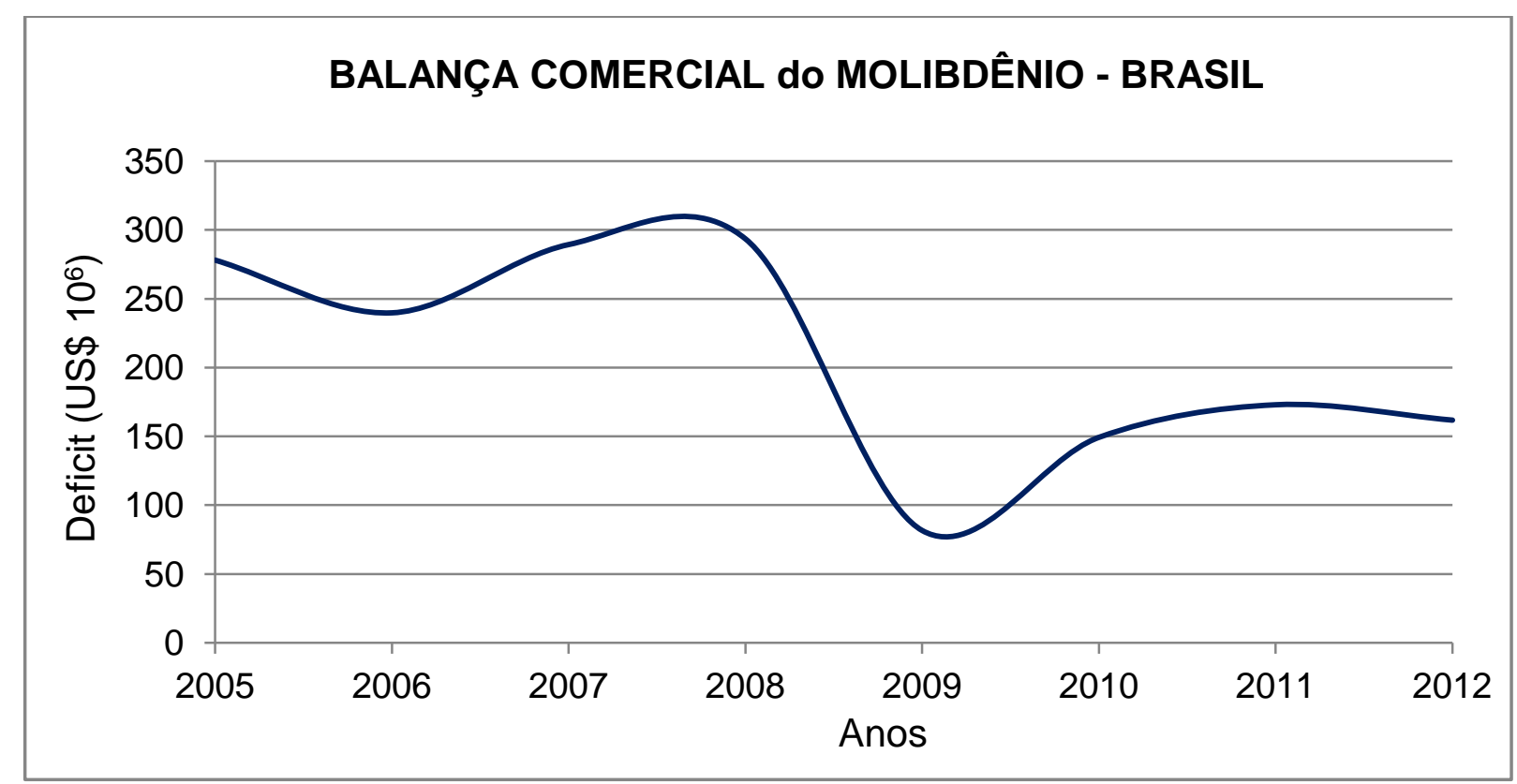

Figura 1.1 - Balança comercial para o molibdênio brasileiro

No Brasil não existem reservas oficiais de minérios de molibdênio e as reservas não oficiais são modestas e, nesse contexto, surge como uma opção de aproveitamento econômico, o minério de molibdênio (molibdenita) gerado como coproduto ou subproduto da mineração de esmeraldas, na região de Campo Formoso e Pindobaçu, BA.

Em Campo Formoso e Pindobaçu mais de 20.000 pessoas dependem economicamente da mineração de esmeraldas e da flotação da molibdenita contida no rejeito da explotação mineral. É notória a ausência de informações sobre o beneficiamento deste mineral, disposição dos rejeitos, agregação de valor aos bens minerais produzidos e sobre os aspectos legais e ambientais.

Outro fator relevante para o desenvolvimento da presente pesquisa é a falta de molibdênio-99, matéria-prima para produção do tecnécio-99, usado na área de medicina nuclear em exames para identificar, principalmente tumores de câncer, risco de enfarte e problemas cerebrais (tomografia computadorizada).

Recentemente, pesquisadores da Escola Politécnica de Lausanne, na Suíça, descobriram que a molibdenita, um dissulfeto de molibdênio, não é simplesmente um material semicondutor, como também supera as qualidades do silício por um fator de 100.000 vezes. A molibdenita pode ser usada em nanotecnologia para a fabricação de transistores, diodos emissores de luz (LEDs) e células solares (RADISAVLJEVIC et al., 2011). 
A presente tese não se propõe unicamente a traçar um perfil analítico atualizado para o molibdênio devido à sua importância industrial, mas principalmente avaliar as características de separabilidade entre a molibdenita e outros minerais hidrofóbicos, especialmente o talco.

Existe uma carência de trabalhos na literatura sobre a separabilidade de dois minerais naturalmente hidrofóbicos como a molibdenita e o talco e sobre fenômenos de superfície que atuam nas suas propriedades e, consequentemente, na separabilidade.

Os resultados desse trabalho, além do interesse acadêmico - separação de minerais hidrofóbicos - poderão auxiliar no fortalecimento da modesta cadeia produtiva nacional de molibdênio, para melhor aproveitamento desse bem mineral, revertido em ganhos de sustentabilidade social e ambiental.

\subsection{DESENVOLVIMENTO DA TESE}

Este trabalho foi desenvolvido em capítulos onde foram abordados aspectos da cadeia do molibdênio e da molibdenita no mercado internacional e nacional e os entraves tecnológicos e opções de melhorias no setor nacional, seguidos da descrição do trabalho experimental realizado e dos resultados obtidos.

O Capítulo 1 faz uma pequena apresentação sobre o molibdênio, ocorrências e suas principais aplicações. Mostra a balança comercial do produto e derivados e apresenta como opção nacional, a molibdenita de Campo Formoso.

O Capítulo 2 informa o objetivo geral e os objetivos específicos do presente trabalho.

O Capítulo 3 destaca, na visão do autor, a inovação contida neste trabalho confrontada com a fronteira do conhecimento. Mostra que a inovação está associada à caracterização tecnológica do processo produtivo e suas matérias-primas e produtos como minérios, concentrados e rejeitos, de forma a gerar conhecimentos para o desenvolvimento de novos processos de beneficiamento.

O Capítulo 4 traz uma revisão bibliográfica segmentada, que enfoca: i) a situação do mercado, em termos de reservas, produção e novos projetos em nível mundial; ii) processamento mineral para concentração dos minerais de molibdênio; iii) fundamentos da separabilidade entre molibdenita e outros minerais. 
O Capítulo 5, Metodologia, foi contemplado em três partes interdependentes e contíguas. A parte inicial do capítulo teve por objetivo caracterizar o estado da arte e planejar a sua utilização na recuperação da molibdenita produzida na Serra de Carnaíba em escala de laboratório. A segunda parte teve por objetivo a realização de um estudo fundamental sobre a separação molibdenita/talco por flotação, com a utilização de diferentes depressores empregados no beneficiamento mineral. A terceira parte foi baseada na aplicação dos resultados obtidos no estudo fundamental na purificação do concentrado de molibdenita atualmente produzido.

O Capítulo 6 mostra os resultados obtidos e uma discussão dos mesmos, fazendo-se uma relação constante com os dados da literatura e sua aplicabilidade.

O Capítulo 7 apresenta as considerações finais sobre esse estudo, avaliando desde a validade dos fundamentos de separabilidade entre molibdenita e outros minerais hidrofóbicos até a aplicabilidade dos resultados aqui apresentados no problema real do aproveitamento da molibdenita de Campo Formoso, na Bahia. 


\section{OBJETIVOS}

\subsection{OBJETIVO GERAL}

O objetivo deste trabalho é a caracterização tecnológica do processo produtivo da molibdenita utilizado pelos pequenos mineradores de Campo Formoso, de forma a detectar deficiências responsáveis pela baixa valorização do concentrado produzido.

Espera-se que o resultado deste trabalho possa contribuir com técnicas racionais e práticas acessíveis a essa comunidade da Serra de Carnaíba, onde atualmente mais de 20.000 pessoas dependem da mineração como único meio de sobrevivência e fonte de renda, promovendo a geração de riquezas dentro de um conceito de sustentabilidade.

\subsection{OBJETIVOS ESPECÍFICOS}

Os objetivos específicos do presente estudo são:

- Traçar um panorama geral para o molibdênio, metal de grande importância para o setor metalúrgico e não aproveitado no Brasil;

- Caracterizar tecnologicamente a molibdenita e os produtos derivados (concentrado e rejeito) responsáveis pela formação da cadeia produtiva do molibdênio no Brasil;

- Realizar um estudo fundamental sobre a separação molibdenita/talco por flotação, com a utilização de diferentes depressores empregados no beneficiamento mineral;

- Aplicar os fundamentos de separabilidade dos minerais molibdenita/talco, visando o enriquecimento e agregação de valor ao concentrado de molibdenita. 


\section{INOVAÇÃO TECNOLÓGICA E A FRONTEIRA DO CONHECIMENTO}

Conforme apresentado na Figura 1.1 a balança comercial brasileira para a cadeia do molibdênio vem apresentando resultados negativos ao longo dos anos e atualmente ultrapassa valores superiores a US\$ 162 milhões/ano tendo atingido picos de US\$300 milhões antes da crise mundial de 2008. É de conhecimento que as reservas nacionais conhecidas de molibdênio são escassas e a molibdenita de Campo Formoso se traduz na única opção comercial atualmente explorada.

A região de Campo Formoso na Bahia sempre se destacou pela atividade econômica ligada à exploração mineral como a produção de minerais de cromo (cromita), ouro e a produção e comércio de gemas, em especial as esmeraldas. As esmeraldas ocorrem em veios ou filões de flogopitito, onde a molibdenita e a sheelita estão associadas.

Segundo Moreira e Silva (2006) o aproveitamento das reservas remanescentes na região dependerá, cada vez mais, de investimentos consistentes em pesquisa geológica, melhores técnicas de extração e segurança, e melhor recuperação dos veios, da gema e de subprodutos, com destaque para a molibdenita. A produção de molibdenita nos últimos anos tem dado sustentabilidade econômica à região de Carnaíba.

Após a contextualização acima surge a questão: onde poderemos inovar em termos de recuperação da molibdenita de Campo Formoso? Objetivamente, dentre as várias possibilidades de inovar, a proposta desta pesquisa diz respeito a inovações tecnológicas para produto e/ou processo.

A inovação deste trabalho está associada à caracterização tecnológica do processo produtivo e suas matérias-primas e produtos como minérios, concentrados e rejeitos, de forma a gerar conhecimentos para o desenvolvimento e/ou aperfeiçoamento de processos de beneficiamento. O objetivo final será produzir um concentrado de molibdenita com requisitos de qualidade equivalentes a produtos consagrados no mercado. Para tanto, faz-se necessária a realização de um estudo fundamental sobre a separação molibdenita/talco (principal contaminante do concentrado de molibdenita), uma vez que os dois minerais são exemplos clássicos de espécies naturalmente hidrofóbicas, de flotabilidade natural, com a utilização de diferentes depressores empregados no beneficiamento mineral. 
O ex-reitor da Unicamp, Prof. Carlos Vogt, defende a tese que o mundo contemporâneo moderno vem enfrentando três grandes desafios do conhecimento: o primeiro desafio, o ecológico, é ligado ao desenvolvimento sustentável, refere-se à transformação do conhecimento em riqueza, preservando a qualidade de vida e o equilíbrio do meio ambiente; o segundo desafio, o tecnológico, refere-se à transformação do conhecimento em valor econômico e social (como agregar valor ao conhecimento?) e o terceiro desafio é a divisão da riqueza (fruto do conhecimento) com a socialização dos seus benefícios (VOGT, 2003).

Segundo Robert Fogel, Prêmio Nobel de Economia em 1993, "Países emergentes têm conseguido crescer graças à grande capacidade de aplicar à sua realidade, tecnologias já existentes no mundo desenvolvido e, em breve, estes mesmos países, também se tornarão nações inovadoras" (FOGEL, 2011).

Para que a inovação proposta neste trabalho seja caracterizada como tal, é necessário que os resultados dos estudos fundamentais (separabilidade molibdenita/talco), que visa o enriquecimento do concentrado de molibdenita, sejam utilizados no setor econômico produtivo, gerando resultados financeiros. Esta é a ótica que deverá nortear os pesquisadores da área tecnológica, pois só haverá inovação se houver um impacto significativo na estrutura de preços, no mercado, na receita financeira, no setor econômico e no bem estar social. É este o propósito desta pesquisa tecnológica. 


\section{REVISÃO BIBLIOGRÁFICA}

A palavra molibdênio é de origem grega, molybdos, que significa parecido com o chumbo e foi aplicado primeiramente para sulfeto de chumbo e a minerais de aparência similar, como a grafita, e também a ocorrências naturais de molibdênio, como a molibdenita.

O molibdênio era desconhecido até o final do século XVIII, quando, Carl Wilhelm Scheele produziu o óxido de molibdênio $\left(\mathrm{MoO}_{3}\right)$, pela queima da molibdenita (ustulação) e liberação de gases sulfurosos. Posteriormente, em 1782, Peter Jacob Hjelm reduziu o $\mathrm{MoO}_{3}$, com carbono, para obter um pó metálico escuro, o molibdênio (BLOSSOM, 1985).

Durante o século XIX, o molibdênio era apenas uma curiosidade de laboratório, até o desenvolvimento de uma tecnologia própria para a sua metalurgia. Em 1891, uma empresa francesa usou o molibdênio em ligas metálicas para produção de chapas (couraças) e observou-se que o molibdênio $(d=10,28)$, apesar de possuir a metade da densidade do tungstênio $(\mathrm{d}=19,25)$, proporcionava as mesmas características ao formar ligas de aço.

Durante a I Guerra Mundial, o molibdênio começou a substituir o tungstênio na fabricação de aços duros e resistentes ao impacto. Em 1930, ocorreu um grande salto tecnológico, com a introdução do molibdênio em ligas de aço rápido usadas em ferramentas. Desde o fim da II Guerra Mundial tem havido um grande desenvolvimento em produtos de molibdênio e suas ligas; essa procura tem sido compensada por novas fontes minerais e por novas tecnologias de processamento, com altas recuperações metalúrgicas (IMOA, 2007).

Outra aplicação do molibdênio é na sua forma de bissulfeto de molibdênio $\left(\mathrm{MoS}_{2}\right)$, que é usado como um aditivo lubrificante em todos os tipos de graxas espessadas que requerem estabilidade química e térmica e condições severas de operação. O transporte (automotivo e ferroviário), mineração, agrícola e militar/aeroespacial são os principais setores industriais onde as graxas de $\mathrm{MoS}_{2}$ são usadas como lubrificantes (EPSHTEYN; RISDON, 2010). 


\subsection{PROPRIEDADES FÍSICAS E QUÍMICAS DO MOLIBDÊNIO}

O molibdênio tem um dos mais altos pontos de fusão de todos os elementos da Tabela Periódica e, por este motivo, é usado frequentemente em ligas de aço de grande resistência. O molibdênio é encontrado em concentrações traço nas plantas e nos animais, embora, em excesso, possa ser tóxico para alguns animais.

O molibdênio é um metal de transição com eletronegatividade de 1,8 na escala de Pauling e possui massa atômica de $95,9 \mathrm{~g} / \mathrm{mol}$. Não reage com o oxigênio ou a água na temperatura ambiente; entretanto, em temperaturas elevadas, o trióxido de molibdênio é formado pela reação da Equação 4.1.

$$
2 \mathrm{Mo}+3 \mathrm{O}_{2} \Rightarrow 2 \mathrm{MoO}_{3} \quad \text { Equação } 4.1
$$

$\mathrm{Na}$ forma pura do metal, o molibdênio é de cor branca prateada, tem dureza elevada e é um metal mais dúctil que o tungstênio. Tem ponto de fusão de $2.623^{\circ} \mathrm{C}$ (somente o tântalo, o rênio e o tungstênio têm pontos de fusão mais altos). É um importante componente de ligas metálicas, uma vez que aumenta a dureza e a tenacidade do aço em altas temperaturas. Comercialmente é utilizado em siderurgia e apresenta, ainda, baixa toxidade em relação a outros metais pesados, como por exemplo, mercúrio, tálio e chumbo (STIEFEL, 2001).

\subsection{MINERALOGIA E GEOLOGIA}

O molibdênio não é encontrado livre na natureza e sua principal fonte comercial é a molibdenita $\left(\mathrm{MoS}_{2}\right)$, que é um mineral acessório em certos granitos, pegmatitos e aplitos. Comumente a molibdenita ocorre em depósitos de filões associada com à cassiterita, scheelita, wolframita e fluorita. Também pode ser encontrada em depósitos metamórficos de contato com silicatos de cálcio, scheelita e calcopirita. O molibdênio também é encontrado em minerais como o wulfenita, powellita e molibdita. $\mathrm{Na}$ Tabela 4.1 encontram-se apresentadas algumas propriedades físicas e químicas dos principais minerais portadores de molibdênio (DANA, 1971; MACHADO et al., 2011). 
Tabela 4.1 - Propriedades físicas e químicas dos minerais de molibdênio

\begin{tabular}{|c|c|c|c|c|}
\hline & Molibdenita & Wulfenita & Powellita & Molibdita \\
\hline Fórmula & $\mathrm{MoS}_{2}$ & $\mathrm{PbMoO}_{4}$ & $\mathrm{CaMoO}_{4}$ & $\mathrm{MoO}_{3}$ \\
\hline Peso específico & $4,6-4,7$ & 6,8 & $4,2-4,3$ & 4,72 \\
\hline Dureza (Mohs) & 1 & 3 & $3,5-4$ & 3 \\
\hline Mo (\%) & 60 & 26,13 & 47,97 & 66,65 \\
\hline Cor & cinza chumbo & $\begin{array}{c}\text { amarelo } \\
\text { alaranjado }\end{array}$ & amarelo & $\begin{array}{c}\text { amarelo, } \\
\text { incolor }\end{array}$ \\
\hline
\end{tabular}

A molibdenita (Figura 4.1) contém $60 \%$ de molibdênio e $40 \%$ de enxofre, tem dureza baixa $(1-1,5)$, densidade elevada $(4,62-4,73)$ e brilho metálico, semelhante ao da grafita, mas distingue-se por sua densidade alta e por uma tonalidade azul de sua cor, além de liberar odores de $\mathrm{SO}_{2}$ quando calcinada. Os cristais, na maioria das vezes, são imperfeitos, cristalizados em placas hexagonais ou sem forma definida, prismas curtos levemente cônicos e estriados horizontalmente, em módulos prateados, moles semelhante à grafita, mas gera um risco cinzento azulado e brilho mais forte sobre o papel ou porcelana. Possui brilho metálico. A condutibilidade elétrica é insignificante na temperatura ambiente, porém aumenta com a elevação da temperatura (BARBOSA; GUSMÃO, 1980).

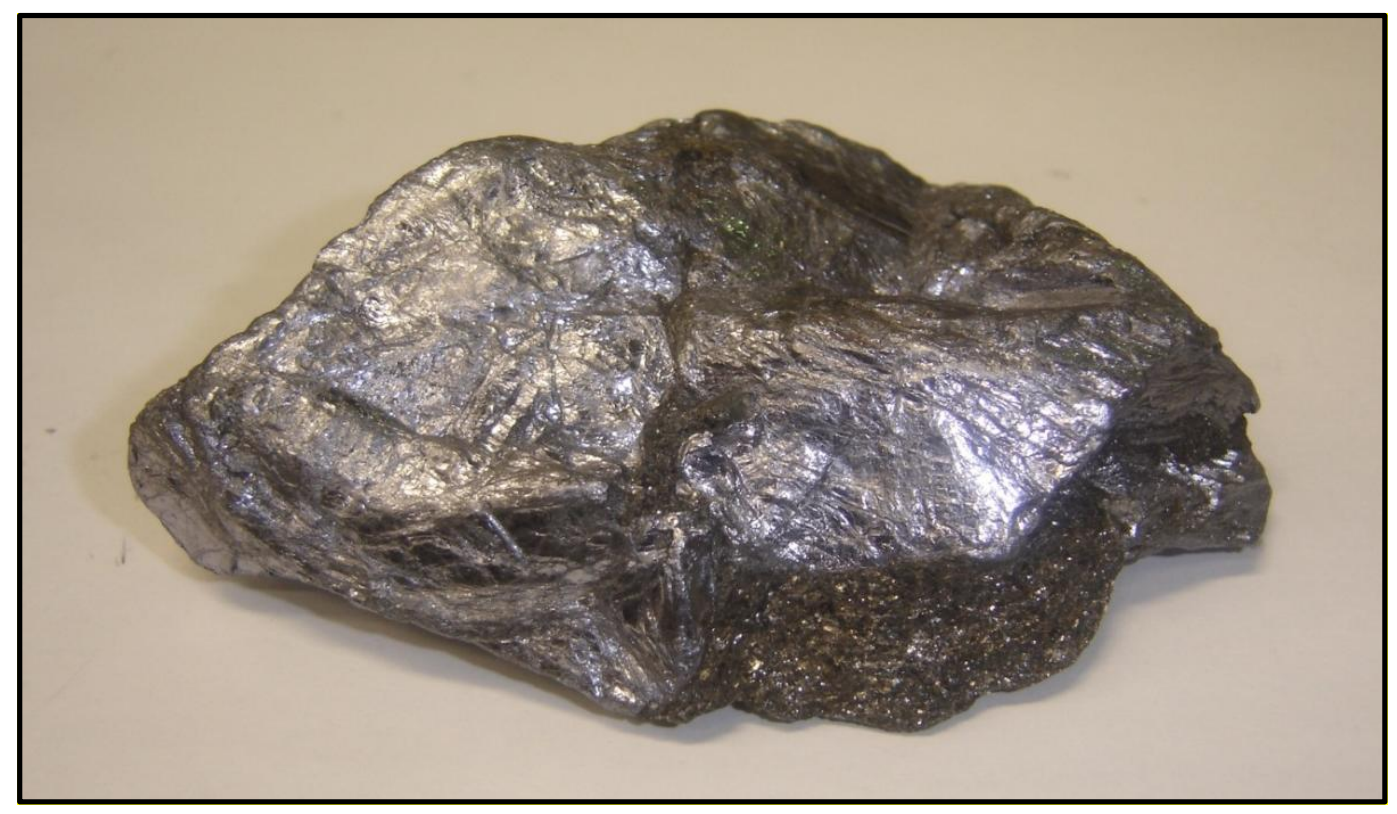

Figura 4.1 - Molibdenita encaixada em micaxisto da Serra de Carnaíba 


\subsection{RESERVAS DE MOLIBDÊNIO}

As reservas de molibdênio do mundo e sua produção (bens primários e semimanufaturados) estão concentradas em poucos países. Para o ano de 2011 , as reservas de molibdênio foram avaliadas em $10 \times 10^{6} \mathrm{t}$ (Mo contido) e cerca de $80 \%$ estão concentradas em três países: China com 43\%, Estados Unidos com $27 \%$ e Chile com $12 \%$. No ano de 2011, as reservas (recursos minerais com informações geológicas e econômicas suficientes para explotação de forma rentável) de molibdênio aumentaram 2\% em relação ao ano de 2010. O gráfico da Figura 4.2 mostra a distribuição, por países, das reservas mundiais de molibdênio (USGS, MCS, 2012).

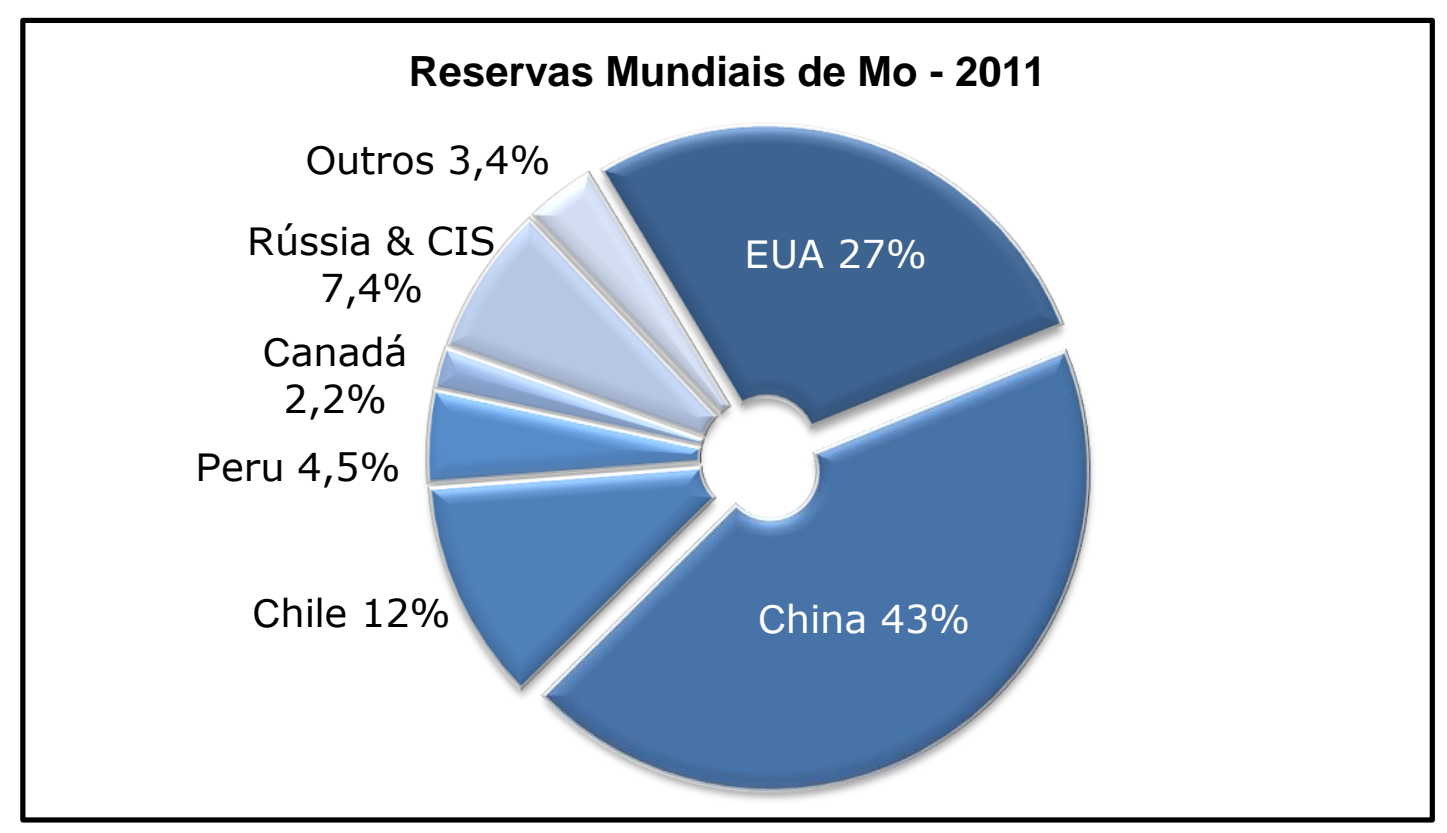

Figura 4.2 - Reservas Mundiais de Molibdênio

A molibdenita, principal mineral de molibdênio, pode ocorrer em dois tipos de depósitos: molibdênio primário (a mais importante fonte) e de cobre pórfiro, onde o molibdênio é aproveitado como subproduto do minério de cobre (NESI, 2007).

\subsection{PRODUÇÃO MINERAL DE MOLIBDÊNIO}

A produção mineral de molibdênio se concentra nos países detentores das maiores reservas. No ano de 2011, China, EUA e Chile representaram $78 \%$ da produção mundial e a partir do ano de 2007, a produção chinesa vem liderando a produção mundial de molibdênio. 
A produção mineral de molibdênio teve um crescimento positivo de $6,5 \%$ ao ano na última década, atingindo as 242.000 t (Mo contido no concentrado) em 2011. O gráfico da Figura 4.3 ilustra a produção mundial por países produtores de molibdênio, no ano de 2011 (USGS, MCS, 2012).

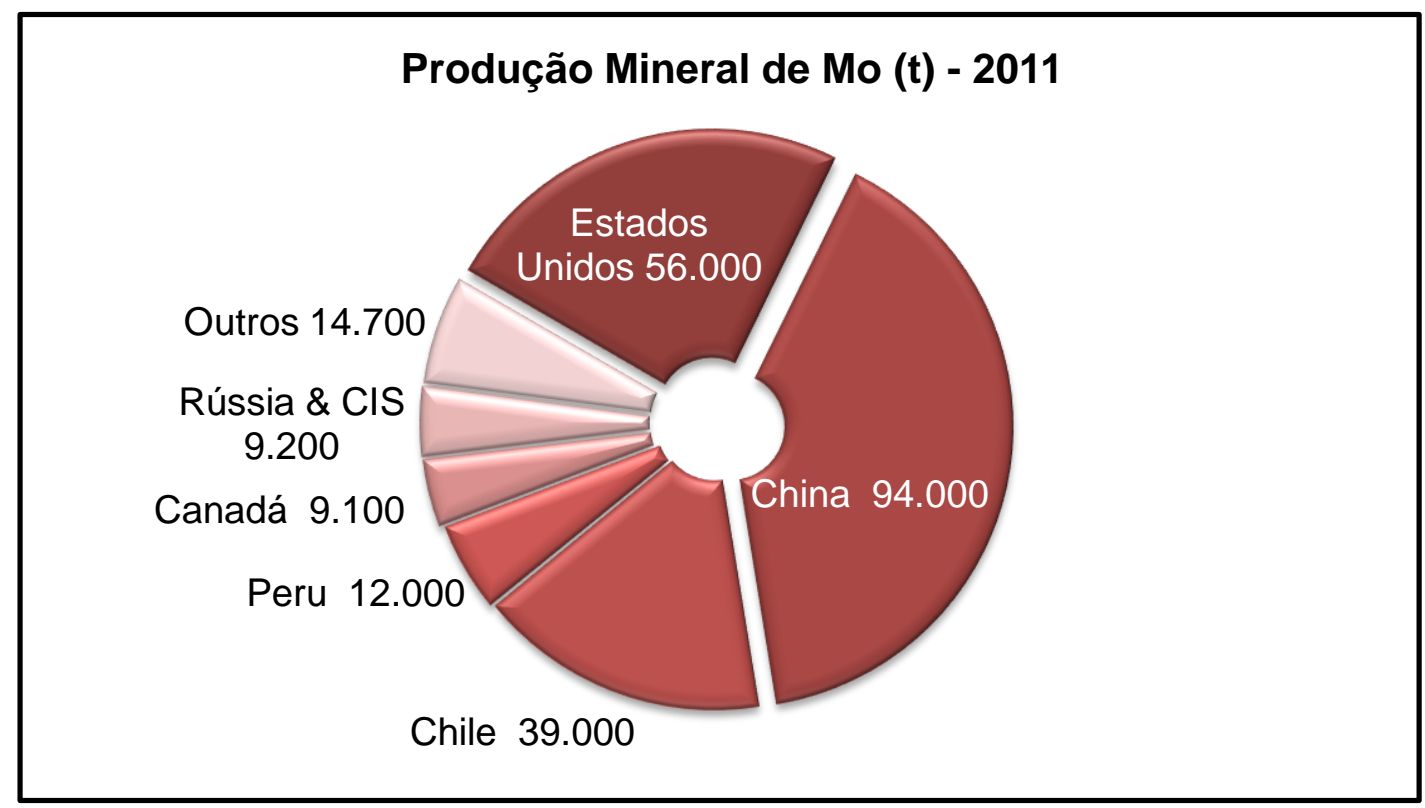

Figura 4.3 - Produção mundial de molibdênio no ano de 2011

Historicamente, a produção de molibdênio por minas primárias representa $45 \%$ da produção mineral total e a produção como subproduto da produção de cobre representa $55 \%$ da produção total. Esta relação pode ser alterada, principalmente em anos nos quais o preço do cobre tem seu valor aviltado por processos especulativos. As principais empresas produtoras de molibdênio, suas minas e dados estimados de produção estão contidos nas Tabelas 4.2 e 4.3 (DONOSO, 2010).

Tabela 4.2 - Empresas produtoras de molibdênio primário e suas minas

\begin{tabular}{cccc}
\hline Minas Primárias & Localização & Propriedade & Produção $(\mathrm{t})$ \\
\hline Henderson & EUA & Freeport McMoran & 18.200 \\
Thompson Creek & EUA & Thompson Creek & 7.700 \\
Endako & Canadá & Thompson Creek & 5.450 \\
Minas Chinesas & China & & 57.670 \\
\hline
\end{tabular}


Tabela 4.3 - Empresas produtoras de molibdênio como coproduto e suas minas

\begin{tabular}{cccc}
\hline Minas de Subproduto & Localização & Propriedade & Produção (t) \\
\hline Bagdad - Sierrita & EUA & Freeport McMoran & 13.150 \\
Codelco Norte & Chile & Codelco & 11.675 \\
Bingham Canyon & EUA & Rio Tinto & 10.500 \\
Los Pelambres & Chile & Antofagasta Minerals e & 7.759 \\
La Caridad & Céxico & Southern Copper Corp & 6.100 \\
Antamina & Perú & BHP Billiton, Xstrata, Teck & 6.050 \\
Toquepala & e Mitsubishi & 5.600 \\
El Teniente & Chile & Southern Copper Corp & 4.955 \\
Minas na China & China & Codelco & 23.560 \\
\hline
\end{tabular}

\subsection{NOVOS PROJETOS DE MOLIBDÊNIO}

Existem diversos novos projetos para produção de molibdênio em novas minas, mas que só deverão ser concretizados caso haja uma recuperação nos preços e no crescimento da demanda em níveis anteriores aos da crise mundial de 2008.

Alguns dos novos projetos visam a produção de molibdênio como subproduto e não têm data para entrada em operação porque dependem das condições econômicas do mercado do cobre. Neste segmento podem-se destacar os projetos para aproveitamento do cobre e molibdênio nas Minas de Mineral Park, Rosemont e Louise Lake, nos Estados Unidos e Magistral, no Peru. A maioria destes projetos encontrava-se, em 2010, em fase de viabilidade econômica (DONOSO, 2011), mas a situação não deve ter mudado desde então.

Outros novos projetos são para produção de molibdênio primário e já tiveram sua viabilidade econômica realizada com um plano específico para implantação nos anos de 2010 e 2012 e poderão sofrer modificações em função do crescimento econômico mundial. Neste segmento podemos destacar os projetos para aproveitamento do molibdênio nas Minas Mt. Hope e Climax (nova mina) nos Estados Unidos, Spinifex Ridge na Austrália, Malmberg na Groenlândia, Ruby Creek no Canadá e Hainan na China (POLYAK, 2008). 


\subsection{APLICAÇÕES}

A versatilidade do molibdênio na promoção de propriedades especiais nas ligas ferrosas, garantiu a esse metal um papel significativo na tecnologia industrial moderna, que exige cada vez mais materiais para serem utilizados sob alta pressão, em grandes intervalos de temperaturas e em ambientes altamente corrosivos. Além disso, o molibdênio encontra um uso significativo como um metal refratário em numerosas aplicações químicas, como catalisadores, pigmentos e lubrificantes.

A capacidade do molibdênio de suportar altas temperaturas com baixo coeficiente de dilatação e elevado ponto de amolecimento, o faz útil nas aplicações que envolvem calor intenso, como em peças de aviões, contatos elétricos, motores industriais e em filamentos elétricos. O molibdênio também é usado em ligas especiais devido à sua resistência à corrosão; a maioria das ligas de aço de grande resistência contém de 8 a 25\% de molibdênio.

Cerca de $75 \%$ do molibdênio é usado na forma de um produto de grau técnico, como o óxido de molibdênio ou ferromolibdênio. Estes produtos são utilizados diretamente na fabricação de ligas de aços em geral (inoxidável, estrutural, ferramental e aços rápido). Os outros $25 \%$ são produtos químicos como catalisadores, lubrificantes, retardantes de chama, inibidores de corrosão, pigmentos e molibdênio metálico. O gráfico da Figura 4.4 ilustra a distribuição setorial das principais aplicações do molibdênio.

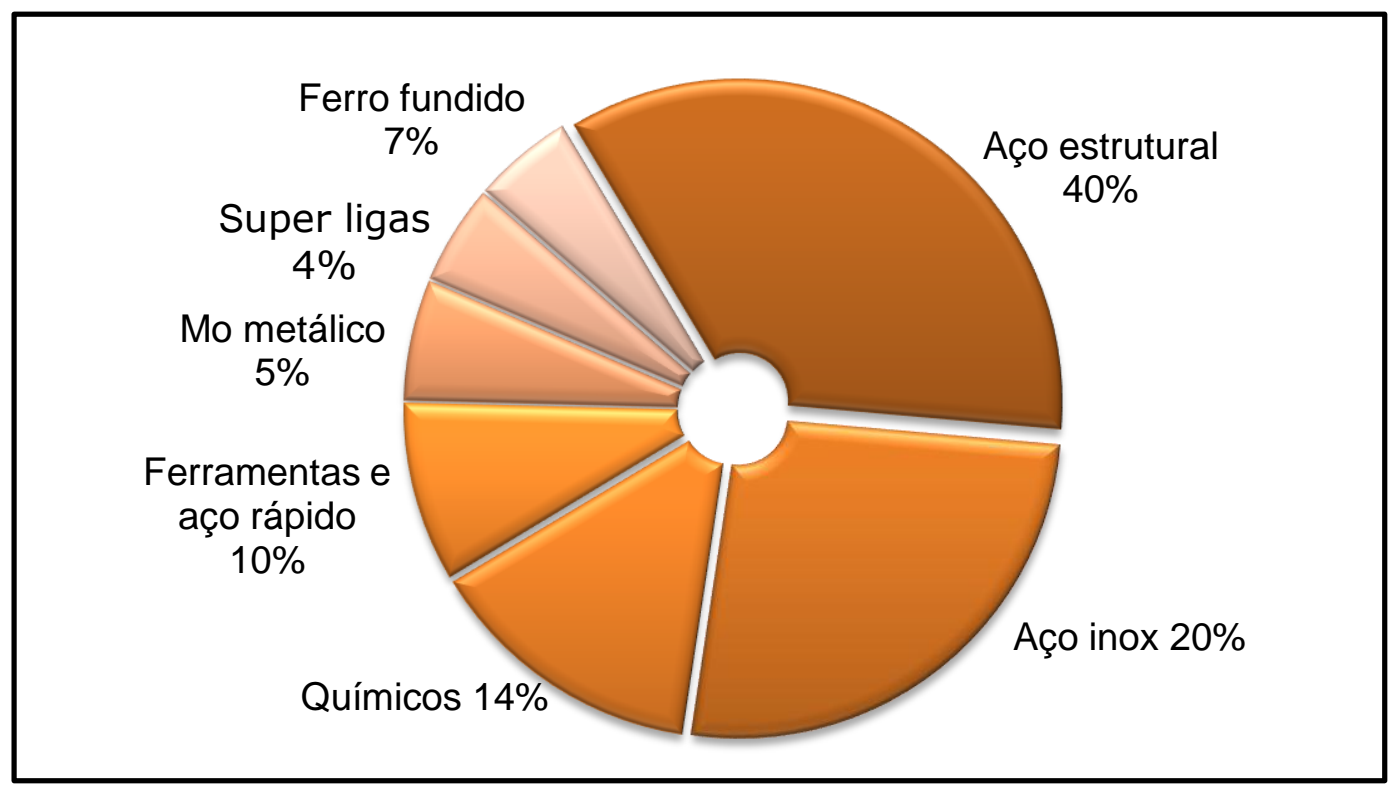

Fonte: IMOA, 2010

Figura 4.4 - Distribuição setorial das principais aplicações do molibdênio 


\subsubsection{Aço estrutural $(0,1$ a $1,2 \%$ Mo)}

Nos aços estruturais o molibdênio, em combinação com o níquel e o cromo, reforça a dureza, a temperabilidade, a tenacidade e a resistência a temperaturas elevadas. Este tipo de aço tem aplicação na indústria aeroespacial, automobilística, naval, construção civil, mineração e na fabricação de peças especiais como engrenagens e eixos, tanques e tubulações, trocadores de calor, etc. Nos aços estruturais tipo HSLA (High Strenght Low Alloy), isto é, aços de alta resistência e baixa liga ( $A R B L)$, o molibdênio é utilizado na razão de 0,1 a $1,2 \%$ sendo o setor industrial de maior aplicação. Um aço HSLA típico possui normalmente menos que $0,15 \%$ de $\mathrm{C}, 1,65 \%$ de $\mathrm{Mn}$ e menos de $0,035 \%$ de $\mathrm{P}, \mathrm{S}$ e outros elementos nocivos. A principal característica destes aços é que são mais resistentes e tenazes do que os aços carbono convencionais, são dúcteis e têm boa conformabilidade, além de ser soldáveis.

\subsubsection{Aço inoxidável (1 a $7 \%$ Mo)}

Nos aços inoxidáveis, o molibdênio e o cromo melhoram a resistência à corrosão. Dentre os aços inoxidáveis, o mais importante é o aço inox austenítico tipo 316 (18\% Cr, 10\% Ni e 2 ou 2,5\% Mo), que representa cerca de 7\% da produção mundial de aços inoxidáveis. Nos últimos anos, a produção dos aços ferríticos tipo moly-grade (1 a $2 \%$ Mo) tem crescido rapidamente e já representa $2 \%$ da produção mundial do aço inoxidável. As mais importantes aplicações do aço inoxidável são na fabricação de equipamentos para indústria química e petroquímica, petróleo e gás, papel e celulose, energia, tratamento de águas, alimentícia e farmacêutica.

\subsubsection{Aço ferramenta e aço rápido (1 a 9\% Mo)}

Nas ferramentas, em geral, o molibdênio, em combinação com o vanádio contribui para o endurecimento secundário dos aços rápidos quando utilizado em proporções de 2-8:1 (Mo:V). Os principais produtos deste segmento incluem as ferramentas manuais, facas e serras, matrizes para forjas, moldes para fundição à pressão e placas de moldagem. No aço rápido, o molibdênio é o componente do $\mathrm{M}_{6} \mathrm{C}$ (carbeto primário), que confere a resistência ao desgaste do aço (IMOA, 2005). As principais utilizações do aço rápido são nas ferramentas de corte e serras para materiais ferrosos e não ferrosos, aço, brocas e fresas. 


\subsubsection{Produtos químicos de molibdênio}

O bissulfeto de molibdênio $\left(\mathrm{MoS}_{2}\right)$ é usado como lubrificante e agente anticorrosivo. O molibdato do sódio é um pigmento alaranjado brilhante utilizado na indústria cerâmica e de plásticos e também é um inibidor de corrosão. O trióxido de molibdênio $\left(\mathrm{MoO}_{3}\right)$ é usado como adesivo entre esmaltes e metais e como agente supressor de chamas e fumaças. $O$ pó de molibdênio é usado como fertilizante em algumas plantas, tais como a couve-flor. Os molibdatos de ferro e bismuto, em conjunto com o óxido de molibdênio, são usados como catalisadores na química do petróleo (IMOA, 2005).

\subsection{PRINCIPAIS PRODUTOS COMERCIALIZADOS DE MOLIBDÊNIO}

Os principais produtos comercializados de molibdênio são concentrados minerais de molibdenita, molibdenita ustulada (trióxido de molibdênio), ligas de ferromolibdênio, molibdênio metálico (pós, chapas, barras, sucatas), compostos químicos (trióxido de molibdênio, sulfeto de molibdênio IV, outros óxidos, hidróxidos e molibdatos) e pigmentos de molibdênio laranja. A Tabela 4.4 mostra a Nomenclatura Comum do Mercosul (NCM), que tem por base o Sistema Harmonizado (método internacional de classificação de mercadorias, baseado em uma estrutura de códigos e respectivas descrições) dos produtos de molibdênio comercializados mundialmente. 
Tabela 4.4 - NCM dos produtos de molibdênio comercializados mundialmente

\begin{tabular}{cc}
\hline NCM & Produto \\
\hline 3815.19 .30 & Catalisador em Suporte, subst. ativa = molibdênio/compostos \\
2830.90 .11 & Sulfetos de molibdênio IV (Dissulfeto de molibdênio) \\
2844.40 .10 & Molibdênio 99 absorv. em alumina, para obtenção tecnécio 99 \\
2825.70 .10 & Trióxido de molibdênio \\
2825.70 .90 & Outros óxidos e hidróxidos de molibdênio \\
2613.10 .10 & Molibdenita ustulada (minérios de molibdênio) \\
2613.10 .90 & Outros minérios de molibdênio, ustulados, seus concentrados \\
2613.90 .10 & Molibdenita não ustulada minérios de molibdênio \\
2613.90 .90 & Outros minérios de molibdênio não ustulados e concentrados \\
8102.10 .00 & Pós de molibdênio \\
8102.91 .00 & Molibdênio em forma bruta, inclusive barra sinterizada, etc \\
8102.92 .00 & Outras barras e perfis/chapas/tiras/folhas, de molibdênio \\
8102.93 .00 & Fios de molibdênio \\
8102.94 .00 & Molibdênio em formas brutas, barras da sinter. \\
8102.95 .00 & Barras, perfis, chapas, folhas, etc. de molibdênio \\
8102.96 .00 & Fios de molibdênio \\
8102.97 .00 & Desperdício e resíduos de molibdênio \\
8102.99 .00 & Outras obras de molibdênio \\
7202.70 .00 & Ferromolibdênio \\
\hline
\end{tabular}

\subsection{PREÇOS E DEMANDA}

A cotação de produtos como o ferromolibdênio e o óxido de molibdênio era função dos preços publicados na semana anterior pela Platts Metal Week (PLATTS, 2010) e servia como referência para fixar as condições de contratos entre produtores, traders e consumidores. O preço publicado era o valor médio semanal comercializado nos mercados da Europa, EUA e Japão.

A partir de 2010, a LME (London Metal Exchange) iniciou a comercialização de metais menores, como o molibdênio e cobalto, com cotações diárias. Atualmente, o molibdênio é comercializado na LME em lotes de 6 (seis) toneladas de molibdênio contido em 10 (dez) toneladas de trióxido de molibdênio, isto é, um teor de $60 \%$ (é admitida uma variação de 5\%). O produto deve estar acondicionado em tambores de 200 ou 250 kg e os níveis de impurezas admissíveis são: 0,50\% de cobre, 0,10\% de enxofre, $0,10 \%$ de carbono, $0,05 \%$ de fósforo e $0,05 \%$ de chumbo (LME, 2011). 


\subsubsection{Preços}

O preço histórico médio anual do molibdênio (base $\mathrm{MoO}_{3}$ ), nos últimos 20 anos foi de 17,40 US $\$ / \mathrm{kg}$. No período de 2004 a 2008, os preços do molibdênio foram cotados em: 36,$40 ; 70,40 ; 54,90 ; 67,10$ e 63,10 US\$/kg, respectivamente. A alta de preços neste período esteve associada ao grande crescimento econômico de países emergentes como China, Índia, Rússia e Brasil. Estas condições positivas de crescimento se mantiveram durante quase todo ano de 2008 , quando se desencadeou a crise financeira mundial nos EUA, e, nos últimos 3 meses de 2008, o preço do molibdênio decresceu de 56,33 US\$/kg para 20,56 US $\$ / \mathrm{kg}$. O gráfico mostrado na Figura 4.5 ilustra a cotação do molibdênio nos últimos 10 anos, podendo ser observada a queda brusca dos preços no final do ano de 2008 (INFOMINE, 2012).

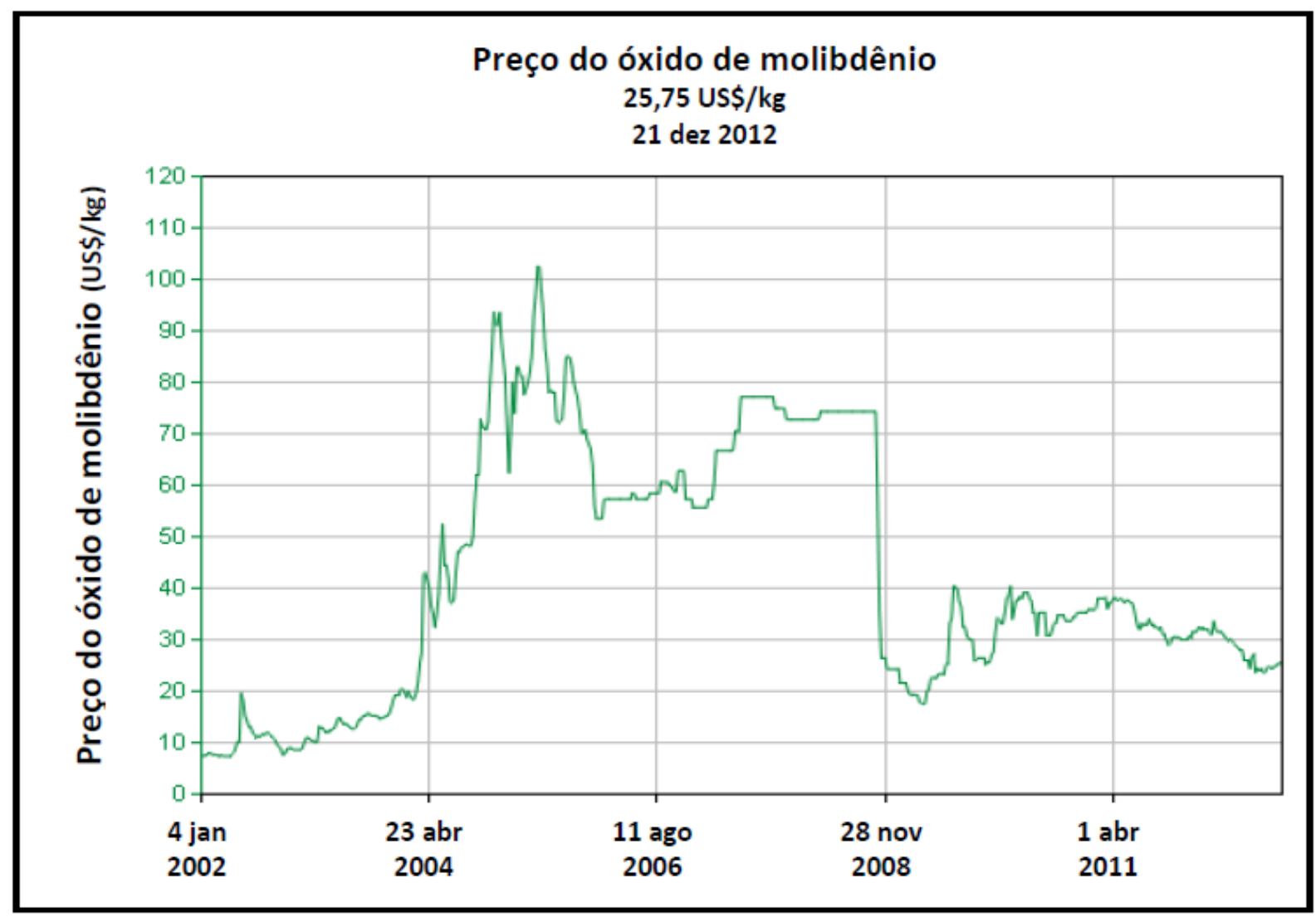

Fonte: INFOMINE, 2012

Figura 4.5 - Cotação do molibdênio de 2002 a 2012

Atualmente, com a retomada do crescimento econômico mundial, o preço do molibdênio está sendo cotado em 25,75 US\$/kg e com perspectivas de crescimento, devendo movimentar volumes maiores a médio prazo. 


\subsubsection{Oferta e demanda}

Molibdênio é um metal com grande intensidade de uso em países com economia crescente, como China, Índia, Brasil e Rússia. Existe uma grande demanda de consumo no oriente médio, com usos específicos em unidades de dessalinização, refinarias de petróleo e na construção arquitetônica (aço estrutural), além do grande consumo em utensílios domésticos, principalmente na China e Índia, por uma parte da população anteriormente sem acesso aos bens de consumo.

A demanda mundial de molibdênio tem crescido à taxa média de $4 \%$ a.a. nos últimos 50 anos. Este crescimento foi interrompido no final de 2008 pela recessão econômica e se o crescimento na demanda de molibdênio continuar nas taxas históricas de 4\% a.a., as novas minas e projetos de molibdênio serão suficientes para atender o mercado, até o ano de 2016.

Na Figura 4.6 estão apresentadas a evolução da produção mineral (oferta) e do consumo (demanda) desde 1995, associados ao preço do molibdênio. Verifica-se um grande equilibrio na curva de oferta e demanda e atualmente existe uma perspectiva de crescimento aos níveis históricos (USGS/MCS, 2012).

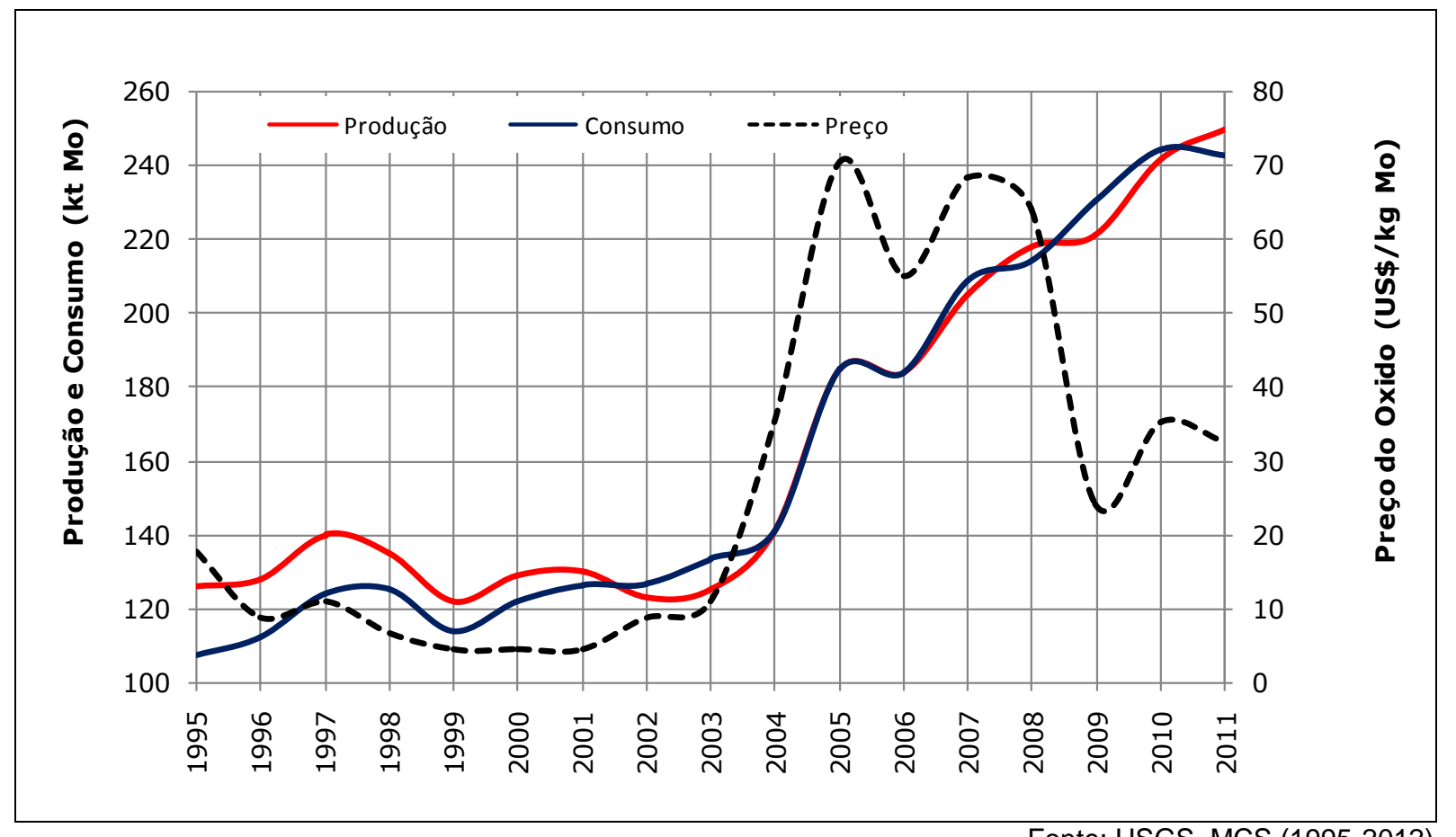

Figura 4.6 - Curvas de oferta e demanda mundiais do molibdênio 
4.9 BENEFICIAMENTO MINERAL, PROCESSOS METALÚRGICOS E ESPECIFICAÇÕES

A grande maioria das empresas que produzem molibdênio têm a sua produção totalmente verticalizada, partindo-se do minério bruto (ROM) até o produto final, que pode ser um concentrado mineral, um óxido de molibdênio, uma molibdenita lubrificante ou uma liga ferromolibdênio. A Figura 4.7 mostra um diagrama em blocos de toda a cadeia do molibdênio (processos e produtos) (IMOA, 2007).

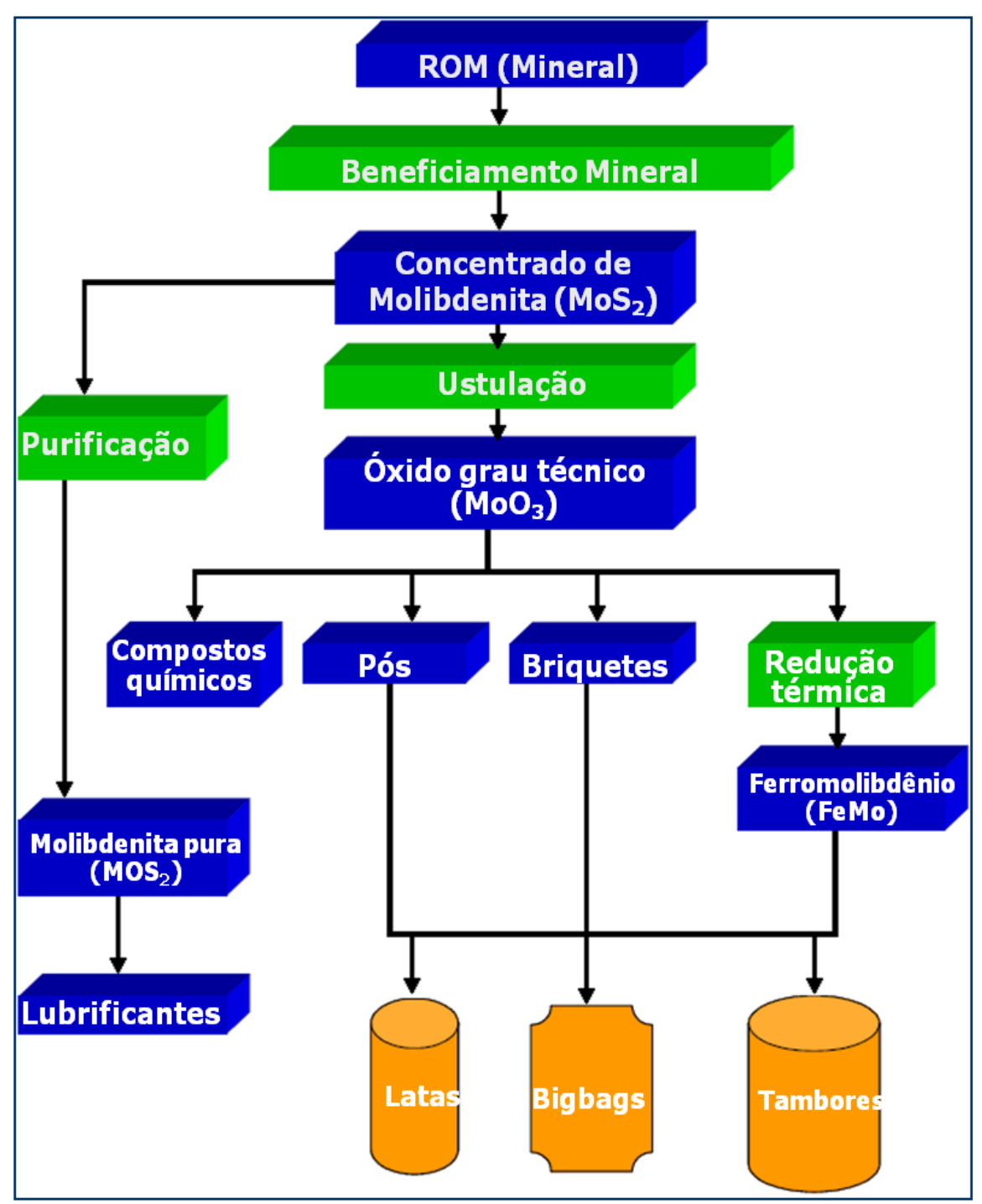

Fonte: IMOA, 2007

Figura 4.7 - Diagrama de blocos da cadeia produtiva do molibdênio (processos e produtos)

O minério de molibdênio tem como característica uma baixa concentração variando no intervalo entre 0,2 a $0,4 \%$ de Mo. A lavra do minério primário de 
molibdênio ou do minério de cobre que contém a molibdenita pode ser subterrânea ou a céu aberto e a maioria das minas tem alta capacidade de produção, em torno de 50.000 t/dia de minério.

\subsubsection{Concentrado de molibdenita}

A cominuição é a primeira etapa do processo de beneficiamento e é realizada em britadores cônicos ou de mandíbulas, seguido de moinhos de barras ou de bolas, até a geração de um produto com uma granulometria menor do que $74 \mu \mathrm{m}$, em que, normalmente, a molibdenita está completamente liberada.

A concentração é feita por flotação, utilizando-se hidrocarbonetos (querosene) como coletor e óleo de pinho como espumante, que de fato, são apenas agentes reforçadores da hidrofobicidade, devido à grande hidrofobicidade natural da molibdenita.

O teor do concentrado na etapa rougher é de $5-6 \%$ de $\mathrm{MoS}_{2}$ e após uma série de etapas de limpeza (cleaners), o concentrado final alcança um teor de $90 \%$ de $\mathrm{MoS}_{2}$, para uma recuperação metalúrgica de $85 \%$. O rejeito final contém aproximadamente $0,035 \%$ de $\mathrm{MoS}_{2}$ (VINCENT; SHIRLEY, 1985). Em algumas minas, o concentrado final é lixiviado com ácido sulfúrico para dissolução de metais contaminantes como chumbo e cobre.

O beneficiamento da molibdenita, como subproduto, é feito a partir de uma flotação bulk de Cu/Mo na usina da Codelco Norte, em Chuquicamata, no Chile. Após condicionamento com sulfidrato de sódio ( $\mathrm{NaHS}$ ), em meio alcalino ( $\mathrm{pH} 11$ ), para depressão dos minerais de cobre, o concentrado de $\mathrm{Cu} / \mathrm{Mo}$ é encaminhado para o circuito de flotação para separação do cobre e do molibdênio. O circuito de flotação é composto por etapas rougher, scavenger e cleaner. Todo o processo de flotação de molibdênio é precedido por condicionamento com NaHS em todas as etapas, de forma a minimizar o carreamento de cobre no concentrado de molibdênio. O concentrado final é obtido após seis etapas de limpeza e contém cerca de $54 \%$ de Mo. A Figura 4.8 mostra o circuito de flotação do molibdênio em operação em Chuquicamata (CODELCO, 2009). 


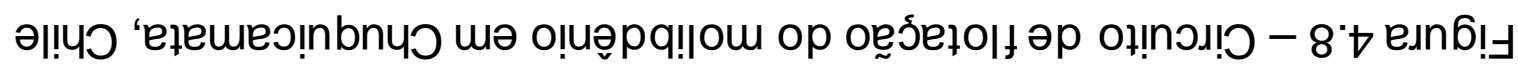

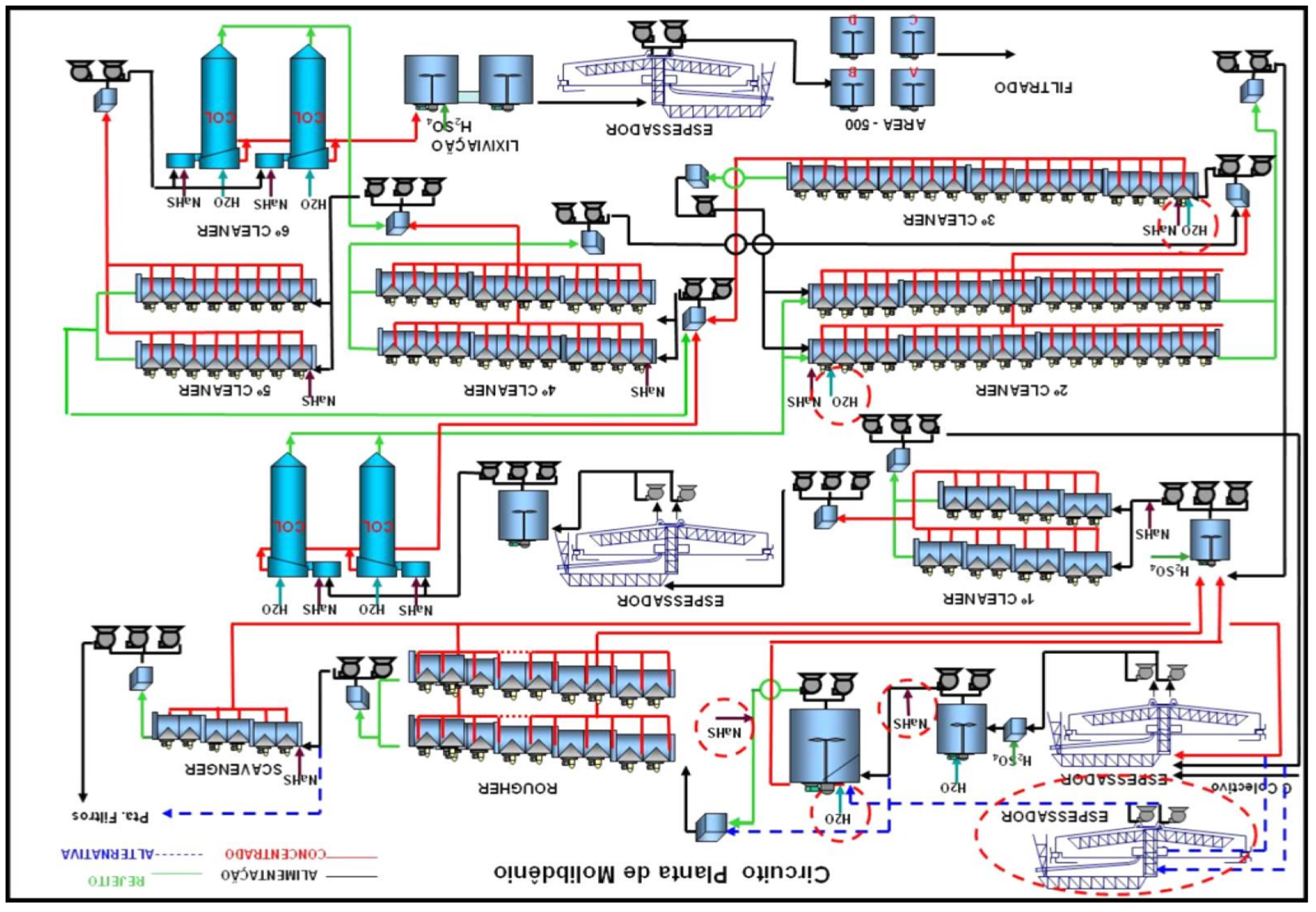


O concentrado de molibdenita comercializado internacionalmente deve conter cerca de $90 \%$ de $\mathrm{MoS}_{2}$, equivalente a $54 \%$ de molibdênio. Concentrados com $80 \%$ e, excepcionalmente $70 \%$ de $\mathrm{MoS}_{2}$, são comercializados em condições especiais. As impurezas não devem exceder a $0,5 \%$ de $\mathrm{Cu}, 0,3 \%$ de $\mathrm{Pb}$ e $0,1 \%$ de $\mathrm{P}$. A Tabela 4.5 mostra o teor do concentrado de molibdênio comercializado por empresas (CHINA MOLY, 2011; SOUTHERN COPPER, 2011).

Tabela 4.5 - Teor dos concentrados de molibdênio

\begin{tabular}{lcc}
\hline \multicolumn{1}{c}{ Empresa } & $\% \mathrm{Mo}$ & $\% \mathrm{MoS}_{2}$ \\
\hline Grupo México (Southern Copper Corporation) & $53-57$ & $88,4-95,1$ \\
China Molybdenum Company & $51-53$ & $85,1-88,4$ \\
China Tungsten & $51-53$ & $85,1-88,4$ \\
\hline
\end{tabular}

Fonte: China Moly; Southern Copper; China Tungsten

\subsubsection{Molibdenita lubrificante}

Bissulfeto de molibdênio é a forma mais comum do mineral de molibdênio e após diversas etapas de purificação (principalmente para redução do quartzo presente), obtem-se um produto para uso direto como agente lubrificante. A sua estrutura, em camadas, o torna um lubrificante muito eficiente e por ser de origem geotérmica, tem durabilidade para suportar calor e pressão. A molibdenita é inerte para muitos produtos químicos e preenche um espaço de uso, onde o grafite tem restrições. Para uso como lubrificante sólido ou em aditivos para fluidos lubrificantes, a molibdenita natural é purificada por flotação e lixiviação ácida até concentrações superiores a $98 \%$.

Como lubrificante sólido as excelentes propriedades lubrificantes de $\mathrm{MoS}_{2}$ são atribuídas ao grande espaçamento entre camadas de S-Mo-S, constituídas por fracas ligações de van der Waals e a distribuição favorável de elétrons nos átomos constituintes. O bissulfeto de molibdênio é termicamente estável em ambientes inertes ou no vácuo, mas no ar ou em presença de oxigênio, começa a oxidar a $\mathrm{MoO}_{3}$ na temperatura de 400ㄷ (EPSHTEYN; RISDON, 2010).

As propriedades lubrificantes da molibdenita são intrínsecas à sua estrutura cristalina hexagonal e em contraste com o grafite, possui boa resistência à água e aos hidrocarbonetos (RISDON, 2003). A Tabela 4.6 apresenta as principais especificações químicas e físicas do bissulfeto de molibdênio lubrificante (CLIMAX MOLYBDENUM, 2011). 
Tabela 4.6 - Especificações químicas e físicas do bissulfeto de molibdênio

\begin{tabular}{cccc}
\hline \multirow{2}{*}{ Produto } & \multicolumn{3}{c}{ Especificação (Grau) do produto } \\
\cline { 2 - 4 } & Técnico & Técnico fino & Técnico super fino \\
\hline bisulfeto de molibdênio (\%) & 98 & 98 & 98 \\
insolúveis em ácido (\%) & 0,50 & 0,50 & 0,50 \\
ferro (\%) & 0,25 & 0,25 & 0,25 \\
óxido de molibdênio (\%) & 0,05 & 0,05 & 0,15 \\
água (\%) & 0,02 & 0,05 & 0,15 \\
óleo (\%) & 0,05 & 0,40 & 0,40 \\
carbono (\%) & 1,50 & 1,50 & 1,50 \\
índice de acidez (mg KOH/g) & 0,05 & 0,25 & 3,0 \\
granulometria, $\mathrm{d}_{50}(\mu \mathrm{m})$ & $16-30$ & $4-6$ & $0,9-1,6$ \\
\hline
\end{tabular}

\subsection{3 Óxido de molibdênio técnico}

O trióxido de molibdênio é obtido pela ustulação do concentrado de molibdenita, em temperaturas entre 500 a $650^{\circ} \mathrm{C}$. As reações químicas (Equação 4.2, 4.3 e 4.4) do processo de ustulação são (IMOA, 2007):

$$
\begin{array}{ll}
2 \mathrm{MoS}_{2}+7 \mathrm{O}_{2} \Rightarrow 2 \mathrm{MoO}_{3}+4 \mathrm{SO}_{2} & \text { Equação } 4.2 \\
\mathrm{MoS}_{2}+6 \mathrm{MoO}_{3} \Rightarrow 7 \mathrm{MoO}_{2}+2 \mathrm{SO}_{2} & \text { Equação 4.3 } \\
2 \mathrm{MoO}_{2}+\mathrm{O}_{2} \Rightarrow 2 \mathrm{MoO}_{3} & \text { Equação 4.4 }
\end{array}
$$

O processo é realizado em fornos de soleiras, na temperatura de $600-700^{\circ} \mathrm{C}$ durante 10 horas. O óxido de molibdênio técnico deve conter no mínimo: 57\% de Mo e no máximo $0,1 \%$ de $S, 0,5 \%$ de Cu e $0,05 \%$ de $P$.

No mercado mundial, o molibdênio é comercializado, em sua grande maioria, na forma de trióxido de molibdênio $\left(\mathrm{MoO}_{3}\right)$, que é a principal matéria-prima para a produção de ligas e aços inoxidáveis (OLIVARES, 2005). O óxido de molibdênio pode ser adicionado na composição da carga do aço ou no banho fundido.

O trióxido de molibdênio ustulado deve conter $57 \%$ de Mo (mín.) e 0,1\% de S (máx.), 0,5\% de Cu (máx.) e 0,05\% de $\mathrm{P}$ (máx.). O maior tamanho (granulometria) admissível é de 4,7 mm (CLIMAX MOLYBDENUM, 2011). 


\subsubsection{Ferromolibdênio}

O ferromolibdênio (FeMo) é produzido pelo processo de redução por aluminotermia do óxido técnico de molibdênio na presença de ferro e é utilizado como fonte de Mo em processos de fusão, quando não se pode reduzir o $\mathrm{MoO}_{3}$.

O ferromolibdênio é obtido pela redução de 30 a $40 \%$ de concentrado de molibdenita ustulada misturado com óxido de ferro. O processo é realizado em fornos de redução, na presença de alumínio, sendo obtidos os lingotes de ferromolibdênio, que são resfriados ao entrar em contato com o ar e, em seguida, moído até a granulometria desejada (IMOA, 2007). A composição química do ferromolibdênio pode ser observada na Tabela 4.7. A produção ocidental de FeMo é de aproximadamente 20.000 t/ano.

Tabela 4.7 - Composição química (\%) do ferromolibdênio

\begin{tabular}{ccc}
\hline Elementos & Ferromolibdênio 65/75 & Ferromolibdênio 60/70 \\
\hline Molibdênio & $65-75$ & $60-70$ \\
Carbono & 0,05 máx. & 0,10 máx. \\
Fósforo & 0,05 máx. & 0,05 máx. \\
Enxofre & 0,10 máx. & 0,15 máx. \\
Cobre & 0,05 máx & 0,05 máx \\
Silício & 1,5 máx. & 1,0 máx. \\
Ferro & $33-23$ & $38-28$ \\
\hline & & Fonte: Clímax Molybdenum, 2011
\end{tabular}

\subsubsection{Molibdênio metálico}

O pó de molibdênio metálico é produzido pela redução do óxido de molibdênio ou do molibdato de amônio com hidrogênio, de acordo com a reação da Equação 4.5 .

$$
\mathrm{MoO}_{3}+3 \mathrm{H}_{2} \Rightarrow \mathrm{Mo}^{0}+3 \mathrm{H}_{2} \mathrm{O} \quad \text { Equação } 4.5
$$

Algumas ligas de molibdênio, como as superligas, não podem conter ferro, então se utiliza o pó de molibdênio em substituição ao FeMo. O pó de molibdênio deve ser pelotizado para uso em aciarias. 


\subsubsection{Produtos químicos}

O óxido de molibdênio técnico é o ponto de partida para uma série de produtos químicos e para o molibdênio metálico. $O$ óxido de molibdênio técnico é purificado por sublimação para a produção do $\mathrm{MoO}_{3}$ puro ou refinado.

A dissolução alcalina do $\mathrm{MoO}_{3}$ em amônia ou soda cáustica produz molibdatos de amônia ou de sódio. Os molibdatos são o ponto de partida para a formação de outros produtos de molibdênio e ainda podem ser calcinados para obtenção do $\mathrm{MoO}_{3} \mathrm{com}$ alto grau de pureza. A Figura 4.9 ilustra a química do molibdênio e seus compostos (IMOA, 2005).

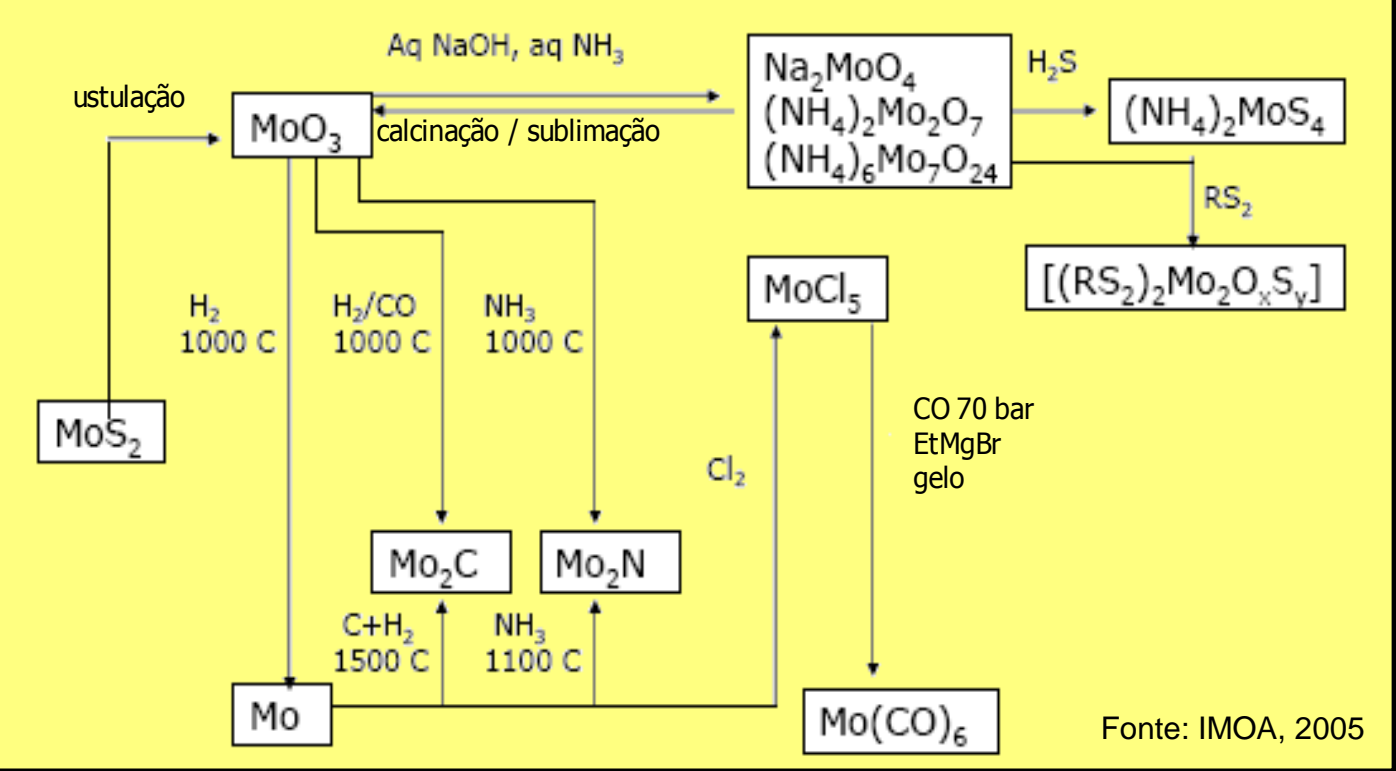

Figura 4.9 - Química do molibdênio e seus compostos

\subsection{MOLIBDÊNIO NO BRASIL}

\subsubsection{Reservas nacionais}

Dentro do contexto internacional, o Brasil não apresenta reservas econômicas de molibdênio, sendo caracterizado como um país importador de concentrados e produtos de molibdênio.

Historicamente, o Distrito Scheelitífero da Borborema Seridó, nos Estados do Rio Grande do Norte e da Paraíba, é citado como a maior fonte potencial de molibdênio devido à ocorrência de molibdenita associada à scheelita (ABREU, 1973). O Projeto Tungstênio/Molibdênio do DNPM, em 1969, indicou que a reserva 
de molibdênio associado ao tungstênio era da ordem de 1.190 t (GUSMÃO, 1981). Um balanço mínero-metalúrgico da Mina Brejuí, $\mathrm{RN}$, realizado por ocasião do projeto, mostrou o teor médio de $0,2 \%$ Mo no minério e de $0,17 \%$ Mo no rejeito do beneficiamento da scheelita (BARBOSA et al., 1969).

Como já mencionado, atualmente, no Brasil, as reservas não oficiais são modestas. No depósito de cobre do Salobo, na Serra dos Carajás, em Marabá, PA, a molibdenita associada ao minério de cobre está na ordem de $110.000 \mathrm{t}$ de molibdênio contido, cujos teores variam de 50 a 250 ppm de Mo no minério. Outro depósito é o sítio Cruxatu, em Barra de Santana, no município de Jucurutu, RN (NESI, 2007).

Outro depósito que vem sendo explotado artesanalmente, desde a década de 1970, está localizado na Serra de Carnaíba em Campo Formoso, BA. Esta produção artesanal de molibdenita é realizada como um co-produto ou subproduto da garimpagem de esmeralda. Não existem dados oficiais sobre este depósito (FONTELES, 2009).

\subsubsection{Balança comercial do molibdênio no Brasil}

No ano de 2011 a balança comercial brasileira do molibdênio apresentou um déficit de US\$160 milhões, com os setores de importação mostrados na Figura 4.10.

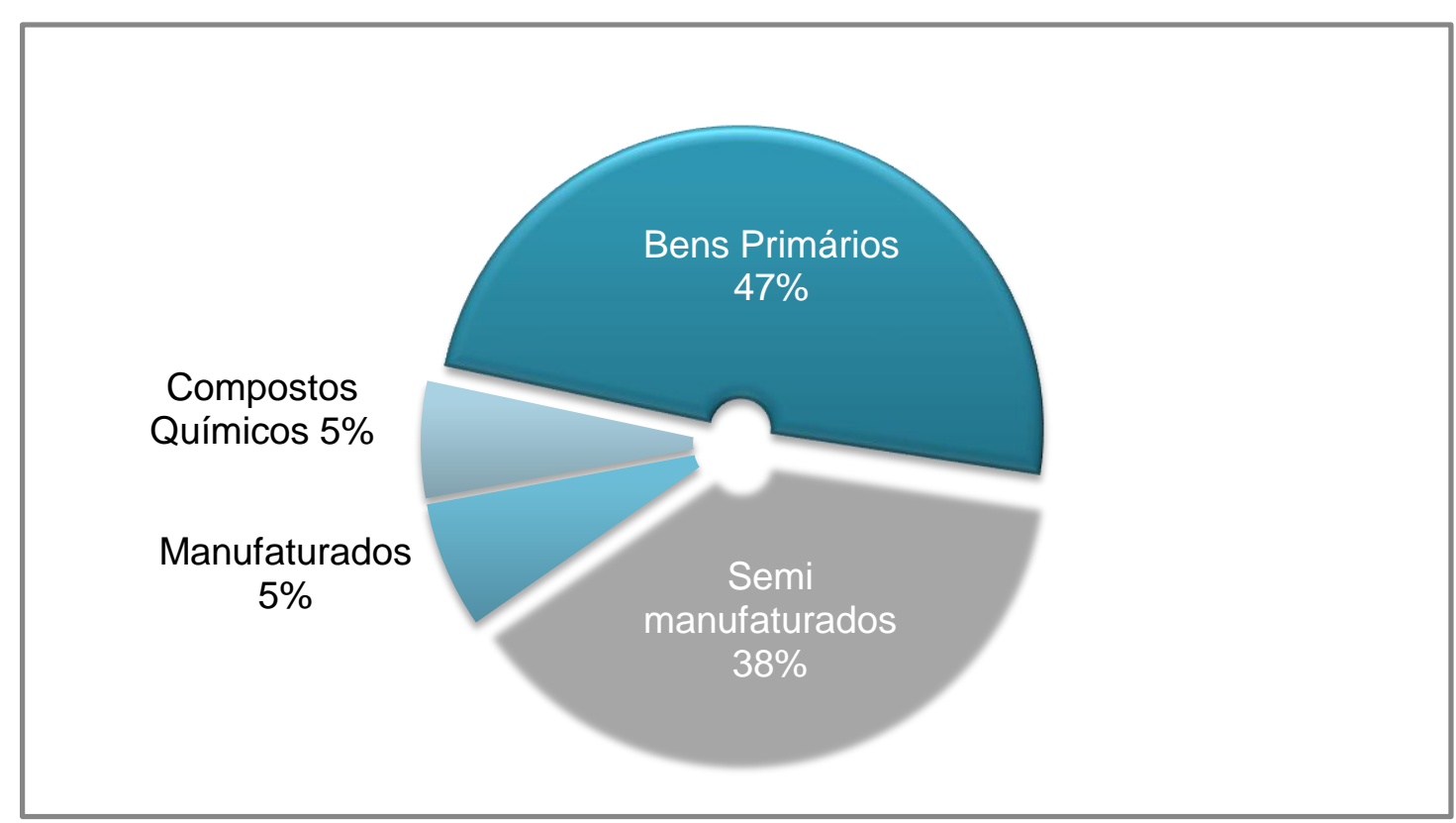

Fonte: Sistema Alice-WEB, MDIC, 2012

Figura 4.10 - Importação de produtos de molibdênio no ano de 2011 
Os bens primários são representados pelo concentrado de molibdenita ustulada, concentrados minerais não ustulados e outros minerais; os semimanufaturados são formados principalmente pelo ferromolibdênio; os manufaturados são os fios e pós de molibdênio, o molibdênio em forma bruta, em barras, perfis, chapas e folhas; e os compostos químicos são o tri-óxido de molibdênio (grau químico), o sulfeto de molibdênio IV (bissulfeto) e outros óxidos, os hidróxidos e molibdatos. A Tabela 4.8 mostra os principais produtos de molibdênio importados pelo Brasil e seu valor nos últimos quatro anos. Verifica-se que antes da crise mundial de 2008, o Brasil importava cerca de US\$330 milhões/ano em produtos e derivados de molibdênio.

Não faz parte desta estatística o desembolso de US\$ 10 milhões (2011) realizado na importação de molibdênio 99 absorvido em alumina para obtenção do tecnécio 99, por se tratar de um produto sintético com rotas especiais de produção.

Tabela 4.8 - Importação brasileira de produtos de molibdênio

\begin{tabular}{|c|c|c|c|c|c|}
\hline & \multirow{2}{*}{ Produtos } & \multicolumn{4}{|c|}{1.000 US\$ FOB } \\
\hline & & 2008 & 2009 & 2010 & 2011 \\
\hline \multirow{3}{*}{$\begin{array}{l}\text { Compostos } \\
\text { químicos }\end{array}$} & Sulfeto de molibdênio IV & 4.086 & 2.383 & 3.368 & 3.023 \\
\hline & Trióxido de molibdênio & 10.889 & 5.094 & 5.819 & 5.064 \\
\hline & $\begin{array}{c}\text { Outros óxidos/hidróxidos de } \\
\text { molibdênio }\end{array}$ & 150 & 68 & 9 & 10 \\
\hline \multirow{4}{*}{ Bens primários } & Molibdenita ustulada & 209.637 & 32.988 & 52.995 & 62.901 \\
\hline & Minérios (ustulado) e concentrados & 24.602 & 8.409 & 19.357 & 20.386 \\
\hline & Molibdenita não ustulada & 1.256 & 0 & 0 & 0 \\
\hline & Minérios e concentrados & 137 & 178 & 61 & 19 \\
\hline \multirow{5}{*}{ Manufaturados } & Pós de molibdênio & 4.206 & 1.940 & 3.025 & 2.368 \\
\hline & $\begin{array}{c}\text { Molibdênio (bruto) e barras } \\
\text { sinterizadas }\end{array}$ & 15.889 & 853 & 2.287 & 2.902 \\
\hline & $\begin{array}{l}\text { Barras, perfis, chapas de } \\
\text { molibdênio }\end{array}$ & 5.578 & 355 & 813 & 370 \\
\hline & Fios de molibdênio & 6.019 & 3.124 & 3.153 & 3.342 \\
\hline & Outros produtos de molibdênio & 520 & 380 & 715 & 584 \\
\hline \multirow[t]{2}{*}{$\begin{array}{c}\text { Semi } \\
\text { manufaturados }\end{array}$} & Ferromolibdênio & 44.604 & 22.478 & 55.938 & 67.922 \\
\hline & Total & 327.573 & 78.250 & 147.540 & 168.891 \\
\hline
\end{tabular}

$\mathrm{Na}$ Tabela 4.9 pode ser observada a origem das importações brasileiras de bens primários, manufaturados, semimanufaturados, e por fim, de compostos químicos. O Chile é o principal parceiro comercial do Brasil, no fornecimento de bens primários (molibdenita ustulada) e semimanufaturados (ferromolibdênio). 
Tabela 4.9 - Importações de bens primários, semimanufaturados, manufaturados e compostos químicos

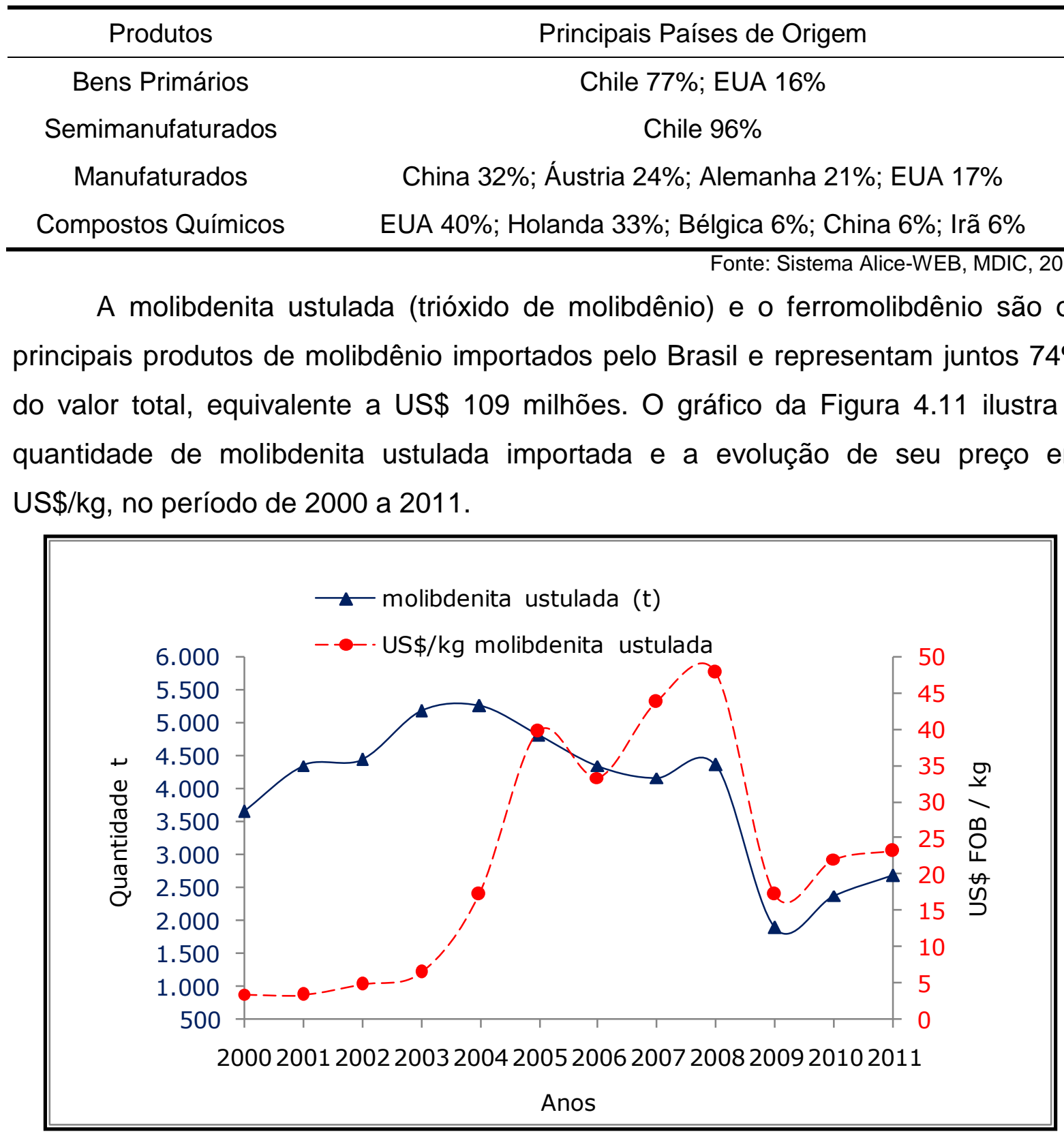

Fonte: Sistema Alice-WEB, MDIC, 2012

Figura 4.11 - Quantidade e preço de importação de molibdenita ustulada

Como pode ser observada na Figura 4.11, a importação de molibdenita ustulada teve um aumento substancial no período de 2003 a 2008, acompanhando o aumento da demanda mundial por commodities metálicas. No final do ano de 2008 , a importação de molibdenita teve uma grande retração e, consequentemente, uma desvalorização no seu preço. Atualmente, a molibdenita ustulada está sendo comercializada a US $\$ 22,50 / \mathrm{kg}$. 
Em 2011 foram exportados US\$ 5,94 milhões, relativos a $262 \mathrm{t}$ de ferromolibdênio, a um preço unitário de US\$22,60/kg. Não houve exportação de bens primários.

\subsubsection{Produção nacional}

Nas décadas de 1970/1980, as minas Brejuí e Barra Verde, em Currais Novos, RN e Timbaúba, PB, produziram concentrados de molibdenita, mas, não existem dados oficiais sobre a produção destas minas.

Oficialmente, não há produção de molibdênio em minas no Brasil. Há registros de uma produção informal de concentrado de molibdenita proveniente da atividade garimpeira, que é recuperada artesanalmente como subproduto da explotação de esmeralda/berilo verde, da região de Campo Formoso, BA. Esta produção garimpeira é estimada em 5 t/ano de concentrado de molibdenita.

No segmento metalúrgico, durante a década de 1980, o Brasil produzia ferromolibdênio a partir de concentrado importado. Esta produção foi interrompida no início dos anos 1990, após a redução das alíquotas de importação determinadas pelo novo governo (COSTA, 2000; GUSMÃO, 1990). Atualmente existe uma pequena produção de ferromolibdênio, destinada principalmente à exportação e que oscila em função das variações do mercado internacional. Para produção do ferromolibdênio, algumas empresas utilizam, como matéria prima, catalizadores exauridos importados a um preço depreciado (Sistema Alice-WEB, MDIC, 2012).

\subsubsection{Novos projetos}

Em junho de 2008, a Carnavale Resources da Austrália encerrou a primeira fase de pesquisa do projeto de molibdênio em Frei Martinho, PB, na região do Seridó. A Fase I do programa de perfuração com 2.046 m perfurados em 18 furos indica um teor médio de 0,20-0,40\% de Mo. O conhecimento geológico adquirido durante a Fase I, em conjunto com os trabalhos de campo, levaram a empresa a requerer novas áreas para pesquisa (CARNAVALE RESOURCES, 2011).

\subsubsection{Antecedentes do beneficiamento de molibdenita no Brasil}

Os resultados do Projeto Tungstênio/Molibdênio realizado no final da década de 1970 (BARBOSA et al., 1969), onde foi dimensionada uma reserva de $700.000 \mathrm{t}$ 
de rejeito com um teor médio de $0,17 \%$ de Mo, motivaram a realização de projetos específicos para recuperação do metal. Algumas propostas foram sugeridas pelo CETEM, no sentido de avaliar os rejeitos das principais minas de scheelita em Currais Novos, mas não foram levadas a efeito (DANTAS, 1981).

No início dos anos 1980 foi realizado um trabalho para purificação de préconcentrado de molibdenita por meio de flotação, partindo-se de um produto com $45,6 \%$ de Mo. O resultado deste trabalho foi a obtenção de um concentrado com $59,3 \%$ de Mo e uma recuperação metalúrgica de $72 \%$. Neste trabalho utilizou-se óleo combustível como coletor (800 g/t), óleo de pinho como espumante $(30 \mathrm{~g} / \mathrm{t})$ e silicato de sódio como depressor da ganga silicatada $(330 \mathrm{~g} / \mathrm{t})$. Os ensaios de flotação foram conduzidos em pH 7,5 (GOMES, 1981).

\subsubsection{Condicionantes geológicos da mineralização na Serra da Carnaíba}

Nos municípios de Carnaíba e Socotó, a mineralização de molibdenita ocorre com a esmeralda e, às vezes, com minerais de scheelita. A mineralização da molibdenita, subproduto da extração de esmeralda, ocorre em veios e vênulos maciços e nos veios pegmatíticos. As gemas estão localizadas em zonas pegmatíticas, intrusivas nos micaxistos, próximas aos corpos plutônicos de composição granítica. As ações metassomáticas de veios e vênulos pegmatíticos, nas ultrabásicas adjacentes, propiciaram a formação da esmeralda. Os filões, contendo esmeralda, apresentam núcleos de quartzo, em geral budinados, resultado da atuação das forças tensionais, envolvidas por flogopita-biotita-xistos, que passam lateralmente para serpentinitos mais conservados (COUTO et al., 1991).

A presença de molibdenita e scheelita com o berilo (esmeralda) indica uma importante ação pneumatolítica, pois o molibdênio e o tungstênio são elementos essenciais de pegmatitos.

$\mathrm{Na}$ Serra de Carnaíba (Carnaíba de Baixo), na faixa situada entre os núcleos garimpeiros Marota e Formiga, ocorre localmente calcopirita associada à pirita maciça. O mineral de cobre ocorre em grãos de tamanhos médios a finos, xenomorfos, e contém cristais de pirita, que foram englobados pela calcopirita. 


\subsubsection{Lavra e beneficiamento de molibdenita em Campo Formoso}

Os depósitos de molibdenita da região da serra de Jacobina distribuem-se em duas áreas: a do garimpo da Carnaíba (município de Pindobaçu), na parte média da região serrana, e a do garimpo de Socotó (Município de Campo Formoso), mais a norte, ambas do lado oeste da serra. O acesso a Carnaíba e a Socotó é feito por Campo Formoso (400 km de Salvador), mas também pode ser realizada por Pindobaçu (Figura 4.12).

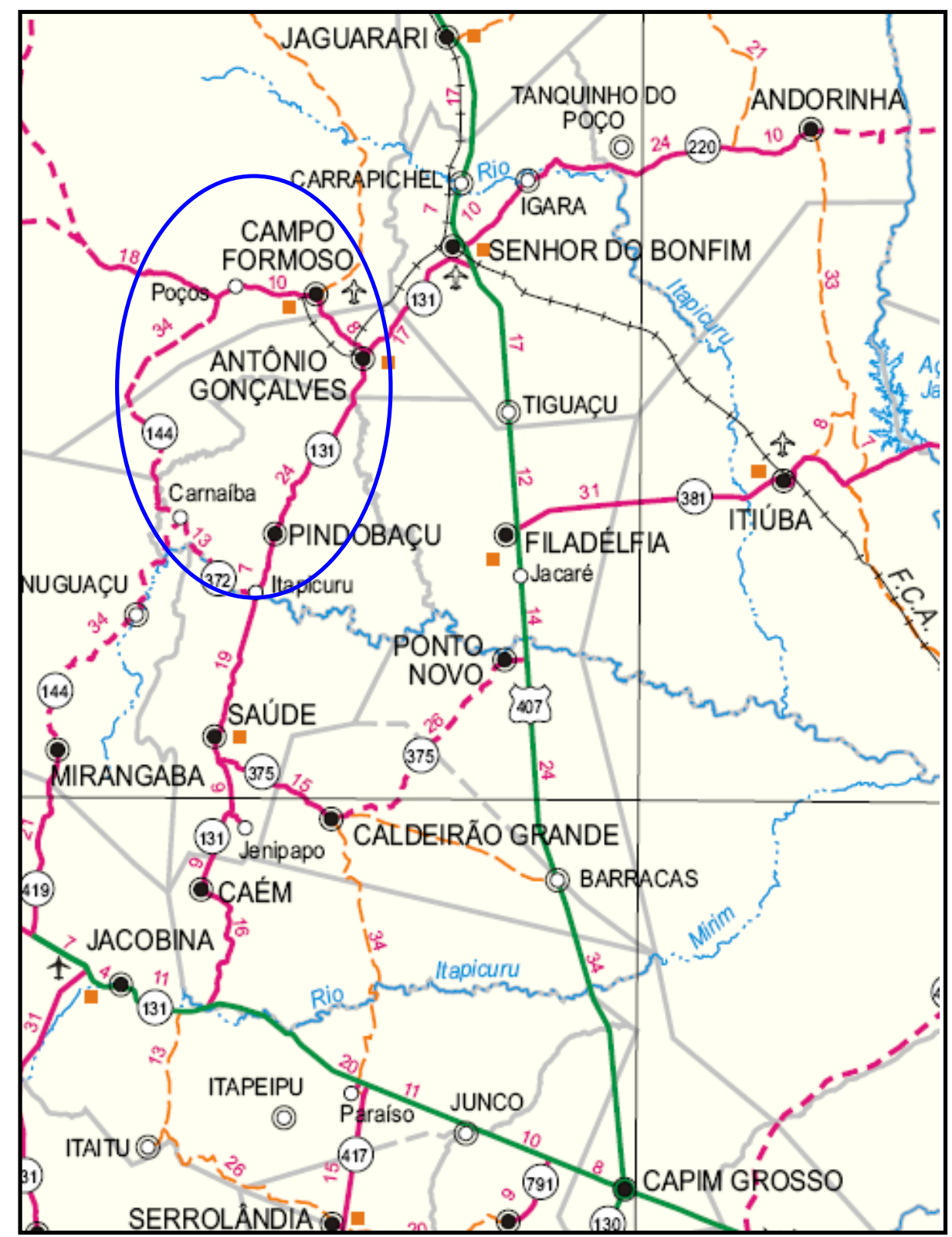

Figura 4.12 - Mapa de Localização dos Garimpos na Serra de Carnaíba, BA

A molibdenita em Campo Formoso vem sendo obtida como um subproduto da garimpagem de esmeralda, por meio de escavações subterrâneas, onde os veios 
mineralizados são seguidos através de galerias (grunas). Para realizar o acesso às galerias, são utilizados poços verticais e galerias horizontais, caso a topografia possibilite (Figura 4.13). O desmonte das rochas encaixantes e do minério é realizado manualmente ou com auxílio de explosivos.

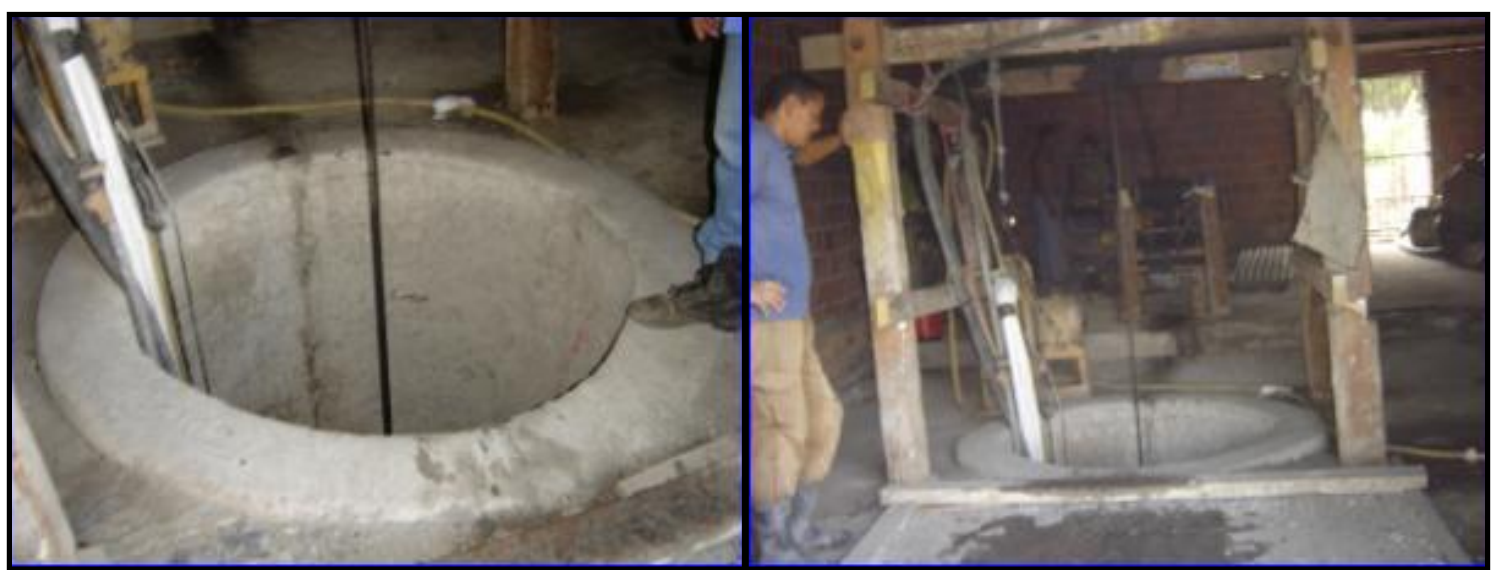

Figura 4.13 - Poço de acesso às galerias

Após a lavra do minério de molibdenita, o mesmo é submetido a uma préconcentração por catação manual, realizada pelos pequenos mineradores (Figura 4.14). Esse pré-concentrado é vendido ou partilhado para outros mineradores que fazem o seu beneficiamento, recebendo ao final do processo e após apuração da produção do concentrado de molibdenita, o preço combinado.

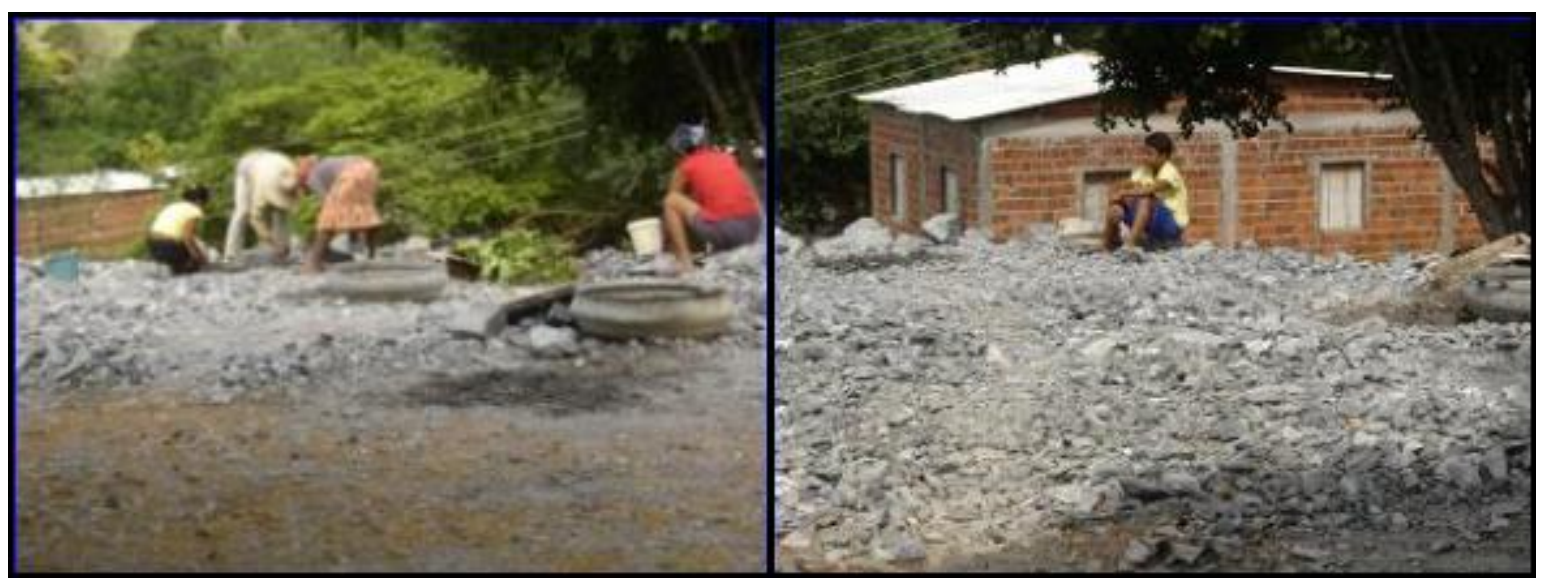

Figura 4.14 - Catação manual de molibdenita em garimpos da Serra de Carnaíba

A primeira etapa do beneficiamento mineral realizado pelos garimpeiros é a etapa de cominuição (britagem em britadores de mandíbulas e moagem em moinho de martelos). Após a redução de tamanho, o minério de molibdenita é flotado em células de flotação rudimentares, utilizando-se óleo de pinho como espumante. A exemplo do que ocorre na flotação do carvão mineral, também naturalmente hidrofóbico, acredita-se que o óleo de pinho tenha também efeito de reforçador da 
hidrofobicidade (CHAVES, 1983). O concentrado de molibdenita produzido na região de Campo Formoso contém entre 30 a $45 \%$ de Mo. A Figura 4.15 ilustra os equipamentos utilizados no beneficiamento realizado pelos garimpeiros.

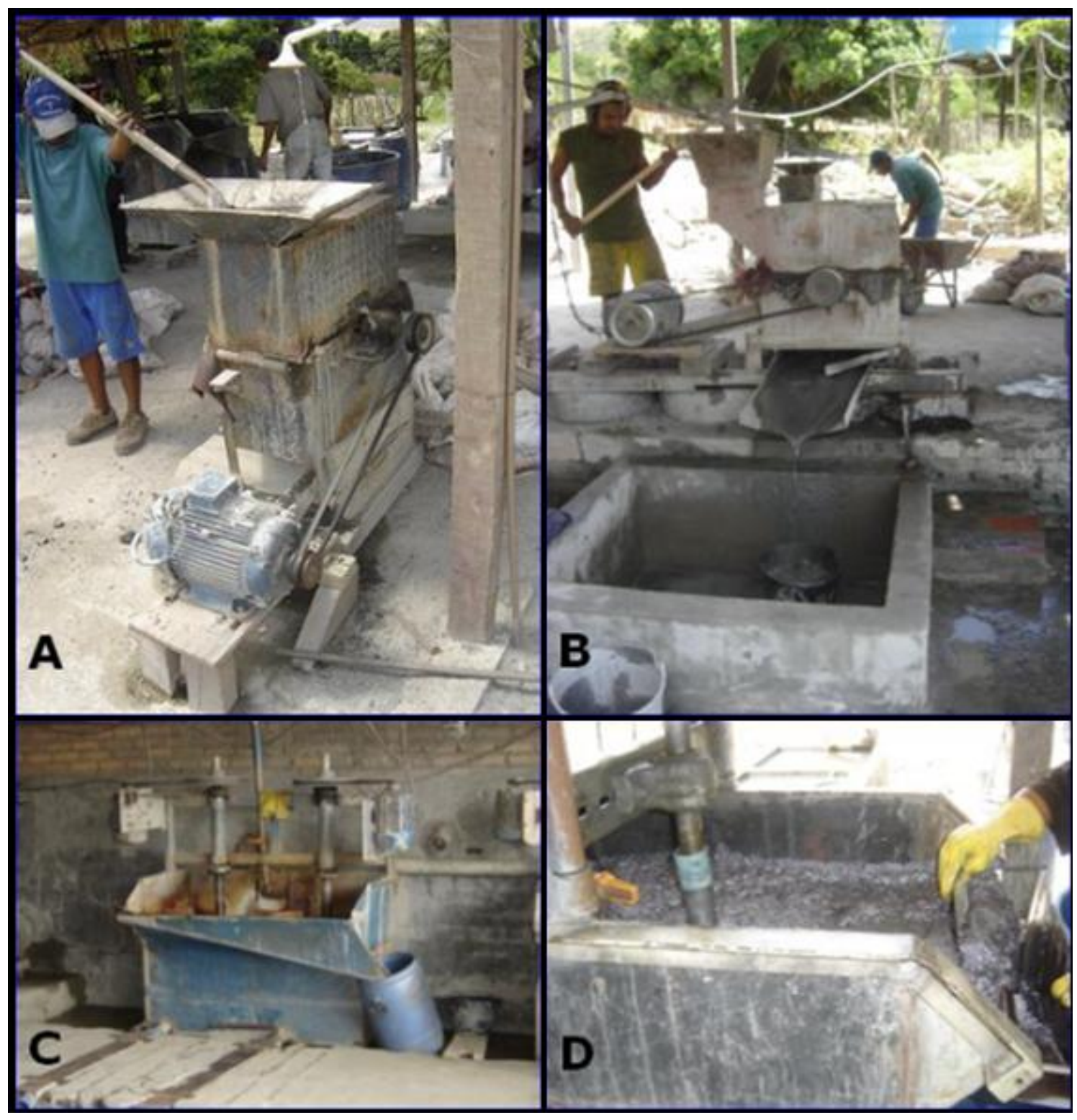

Figura 4.15 - Britador de mandíbulas (A); Moinho de martelos (B); Células de flotação (C); Processo de flotação (D)

O processo de beneficiamento utilizado pelos garimpeiros para a recuperação de molibdênio em Campo Formoso está representado no fluxograma da Figura 4.16. 


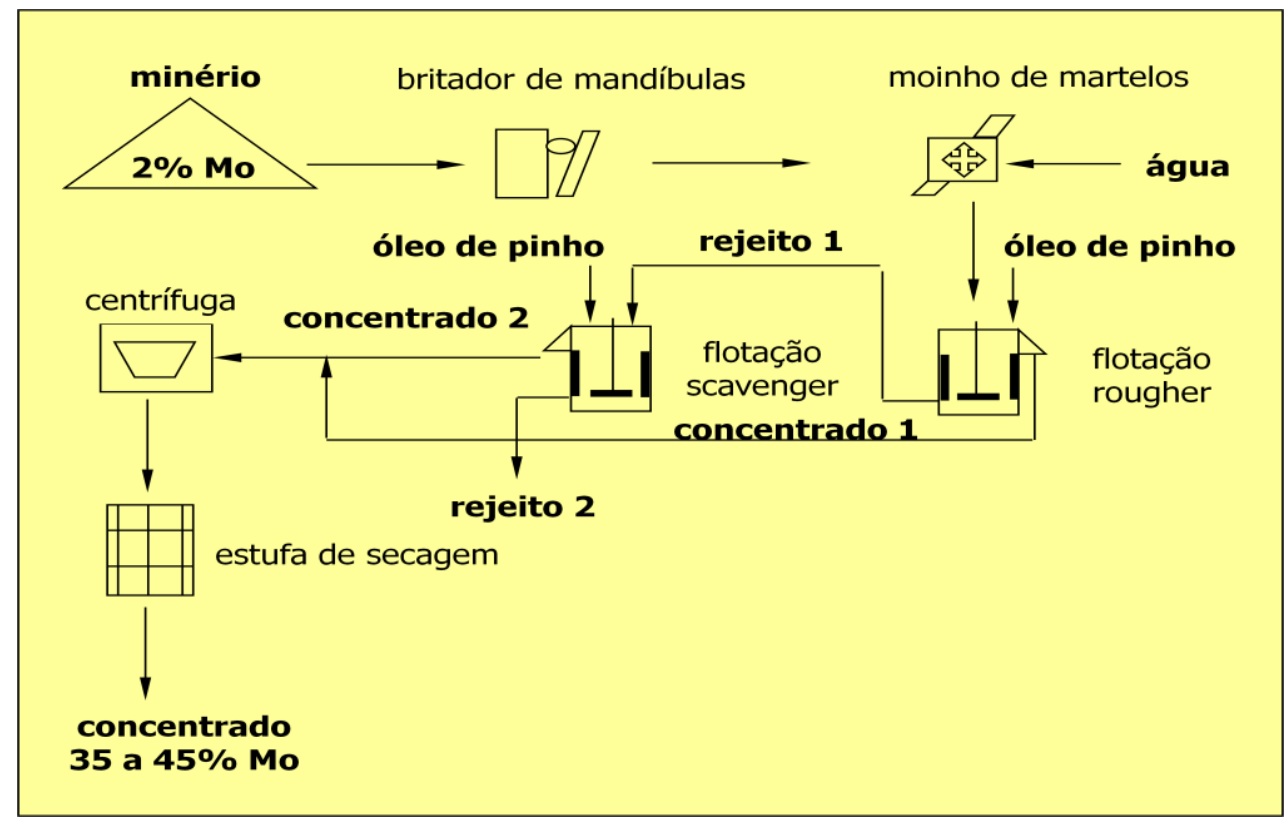

Figura 4.16 - Fluxograma de beneficiamento utilizado na recuperação de molibdenita de Campo Formoso, BA

Em Campo Formoso são comercializados e processados dois tipos de minério de molibdenita (localmente chamada de "estanho"). O primeiro é considerado leve, quando a molibdenita encontra-se intercrescida com clorita, entre as placas de flogopita (Figura 4.17). O segundo é considerado pesado, quando a molibdenita está associada de forma maciça nos filões de quartzo contido nas rochas encaixantes de micaxisto.

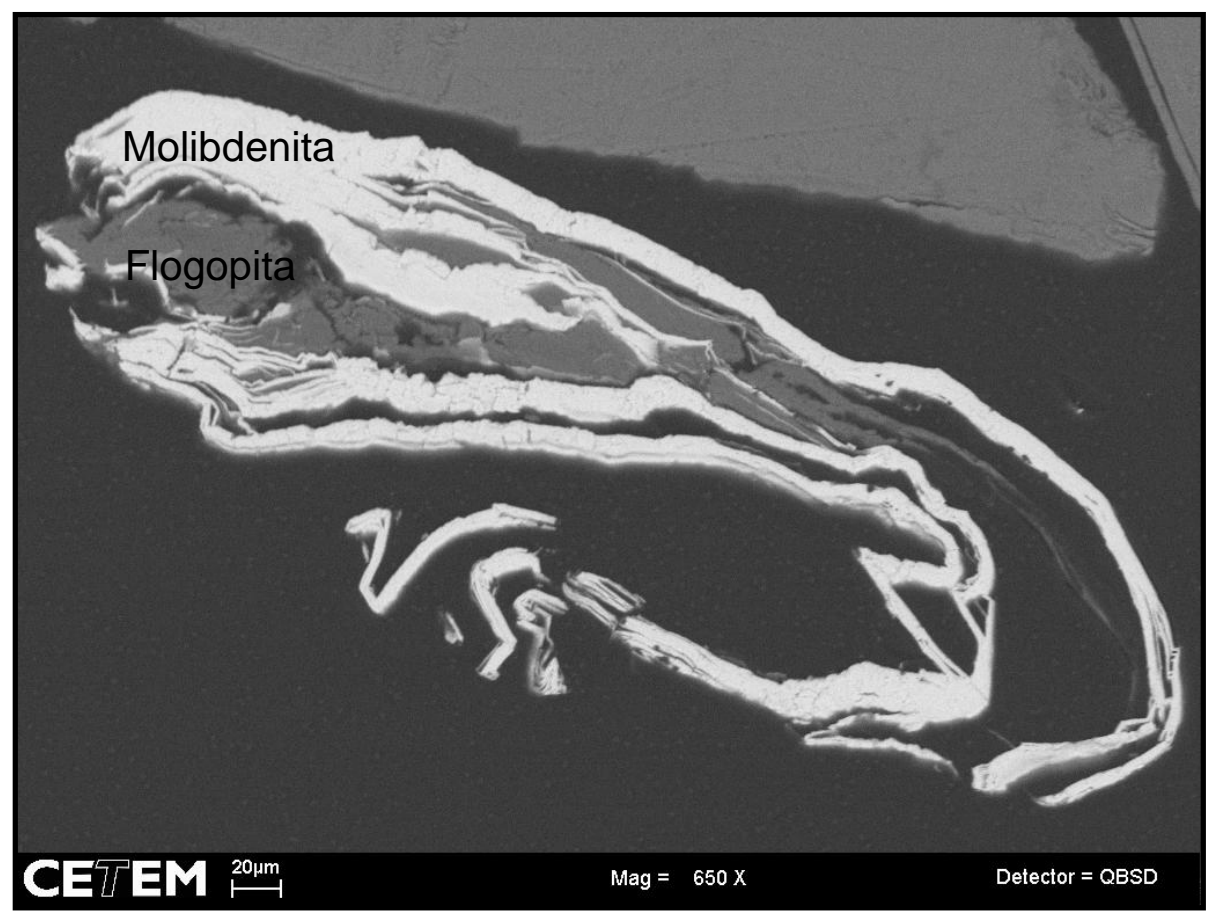

Figura 4.17 - Imagem de MEV da molibdenita intercrescida com clorita e flogopita 
A comercialização dos pré-concentrados de molibdenita que alimentam as unidades de beneficiamento (flotações) é feita por meio da compra no mercado "spot" local e de acordo com o teor de molibdenita observado na rocha ou segundo parcerias (consignação), em função da quantidade de concentrado obtido após a flotação.

Segundo informações locais, o teor de molibdênio no minério pré-concentrado é de $2 \%$. O beneficiamento por flotação proporciona concentrados com $40 \%$ de molibdênio. O preço do concentrado com $50 \%$ de molibdênio estava sendo negociado, em 2008, a $R \$ 30,00 / \mathrm{kg}$ e em 2011, a $R \$ 25,00 / \mathrm{kg}$.

\subsection{PROCESSOS PARA SEPARAÇÃO MOLIBDENITA/TALCO EM CONCENTRADOS E MINÉRIOS.}

Os concentrados de molibdenita obtidos como subproduto da produção de cobre ou como produto principal ainda contêm uma parcela significativa de contaminantes. O concentrado de molibdenita comercializado internacionalmente deve conter cerca de $90 \%$ de $\mathrm{MoS}_{2}$, equivalente a $54 \%$ de Mo.

No beneficiamento de minérios de molibdenita, a separação desta de outros minerais normalmente é baseada na sua flotabilidade natural, que muitas vezes pode ser reforçada utilizando-se a adição de hidrocarbonetos apolares que reforçam a hidrofobicidade natural. Os depósitos pórfiros de molibdênio e os minérios sulfetados de cobre/molibdênio representam a principal fonte de molibdenita que é explorada comercialmente. Em alguns minérios, a molibdenita e o talco ocorrem juntos.

O principal fator prejudicial à pureza do concentrado de molibdenita diz respeito à presença de minerais naturalmente hidrofóbicos, como talco, grafite e enxofre nativo. Devido às características hidrofóbicas destes minerais serem similares às da molibdenita, os mesmos tendem a se concentrar conjuntamente (coflotação).

A solução clássica para este problema é a oxidação superficial da superfície da molibdenita, em temperaturas de $200-300^{\circ} \mathrm{C}$, de forma a reduzir sua flotabilidade. O talco presente não seria afetado por esta operação, mantendo suas propriedades hidrofóbicas naturais, e seria removido, em seguida, por um processo de flotação reversa (SPEDDEN et al., 1971). 
Outro fator importante que afeta a recuperação primária de molibdenita diz respeito à sua superfície anisotrópica e seu efeito de faces e bordas. Em muitos processos industriais utiliza-se uma segunda etapa de moagem (remoagem), com objetivo de buscar maior liberação da molibdenita. Esse procedimento faz com que ocorra um aumento da área relativa às bordas, que são hidrofílicas e formam pontes de hidrogênio com a água quando em suspensões aquosas, diminuindo assim a sua hidrofobicidade natural (VICENT; SHIRLEY, 1985).

Diversos estudos têm sido desenvolvidos com objetivo de realizar a separação efetiva entre a molibdenita e os minerais hidrofóbicos contaminantes, como o talco.

Mathieu e Bruce (1974) realizaram um estudo prospectivo para separação do talco e da molibdenita em minérios e concentrados, baseado em algumas de suas principais características físicas como: a molibdenita é um sulfeto metálico condutor, com densidade de 4,7, enquanto o talco é um silicato de magnésio, com densidade de 2,7 e não condutor eletrostaticamente. Com base nessas diferenças físicas, foram estudadas nesse trabalho diferentes operações unitárias de separação: a separação eletrostática, a hidroseparação (processo gravítico) e a flotação.

Os testes de separação eletrostática foram realizados no equipamento Carpco High Tension Separartor, Model HB-16-114 e a separação molibdenita/talco se mostrou viável em granulometrias acima de $105 \mu \mathrm{m}$. Em granulometrias inferiores, a separação é prejudicada pela formação de agregados molibdenita/talco.

A hidroseparação (elutriação) foi efetiva somente para amostras onde o talco se encontrava em frações muito finas $(-45 \mu \mathrm{m})$, pois, mesmo existindo diferenças significativas entre as densidades da molibdenita e do talco, o fator forma (lamelas) e a flotabilidade natural de ambos minerais prejudicam a eficiência deste método de separação.

A separação da molibdenita do talco por flotação é prejudicada, não só pela afinidade desses minerais com os hidrocarbonetos, mas também pela reação de ambos com agentes depressores de cadeia longa (como os polissacarídeos) tornando mais difícil a separação, na medida em que, a relação talco/molibdenita aumenta. Nos estudos realizados foram utilizados sulfato de alumínio/silicato de sódio, Depramin ${ }^{\circledR}$ (carboximetil celulose) e Lignosol ${ }^{\circledR}$ (sulfonato de lignina). 
A combinação sulfato de alumínio/silicato de sódio como agente depressor (para o talco) proporciona uma separação aceitável quando a concentração do talco é baixa (em torno de $0,25 \% \mathrm{p} / \mathrm{p}$ ). Em concentrações maiores de talco, o uso do Depramin (agente depressor do talco) e do Lignosol (agente depressor da molibdenita) produziu concentrados de molibdênio dentro das especificações exigidas pelo mercado consumidor ( $>54 \% \mathrm{Mo})$.

\subsubsection{Pima process, separação talco-molibdenita}

A empresa Cyprus Mines Corp. licenciou um processo desenvolvido pela sua controlada Cyprus Pima Mining Co. para enriquecimento da molibdenita contida em minérios e concentrados, de forma a melhorar a separabilidade dos minerais silicatados hidrofóbicos que contêm magnésio, como o talco. Neste processo, a polpa mineral de molibdenita é tratada primeiramente com um sal metálico de uma base fraca e um ácido forte, como o sulfato de alumínio, e depois com sal solúvel de ácido fraco, como o silicato de sódio, com o intuito de promover modificações nas cargas superficiais dos minerais, principalmente do talco, e alterar o seu potencial zeta (KUSAKA et al., 1997). Após o tratamento, a polpa mineral é submetida ao processo de flotação, onde a molibdenita enriquecida é flotada e a fração que contém o talco é deprimida e descartada como rejeito (PARKINSON, 1976). A Figura 4.18 mostra o fluxograma geral da Cyprus Pima Mining Co. 


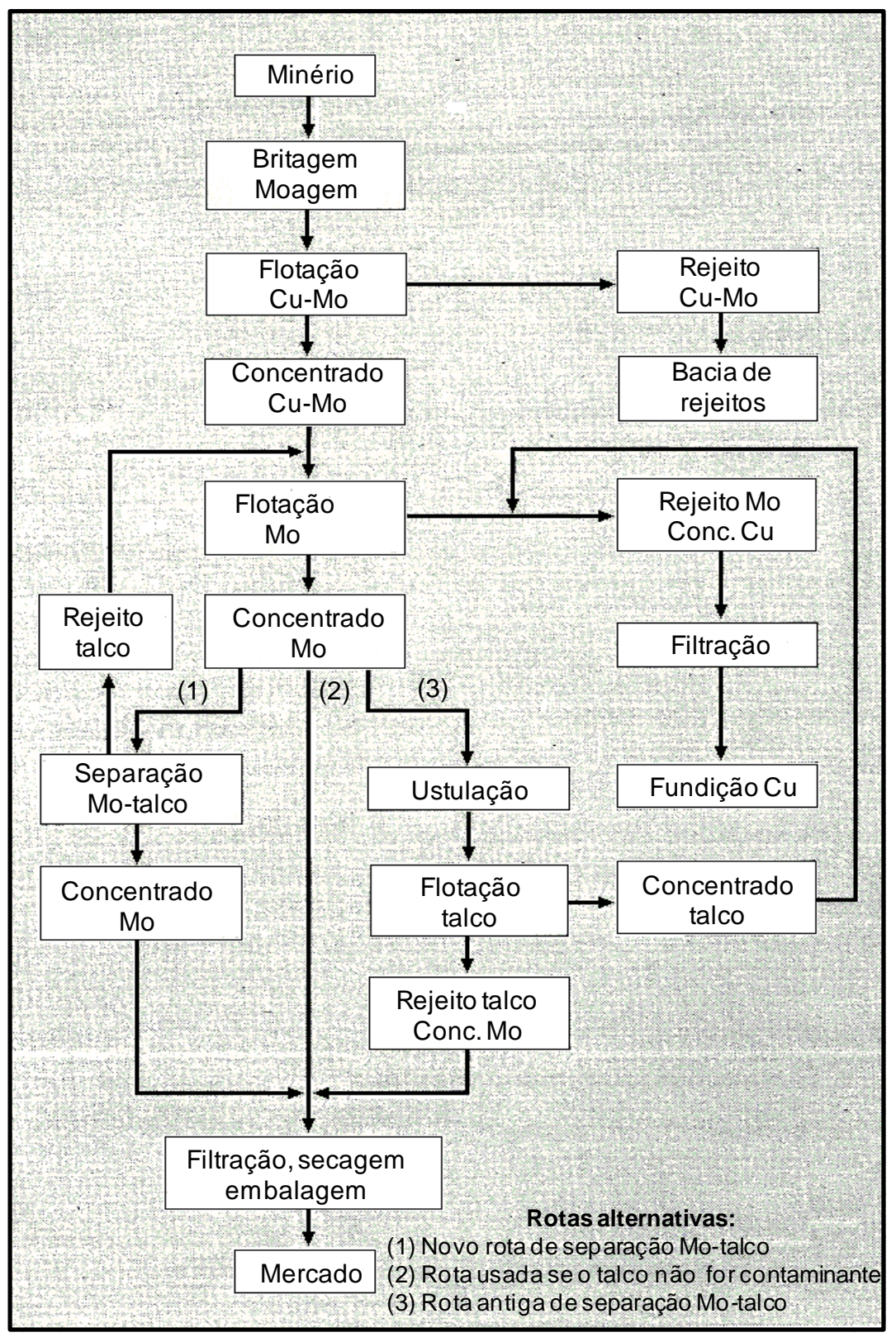

Figura 4.18 - Fluxograma geral da Pima Mining (adaptado de PARKINSON, 1976)

Neste processo foi utilizada uma amostra de um pré-concentrado de molibdenita de baixo teor, produzido pela empresa Pima Mine, com $18 \%$ de molibdenita, $4 \%$ de calcopirita, 5\% de pirita e 69\% de insolúveis em ácido clorídrico, sendo a maior parte composta por talco. Os melhores resultados foram obtidos quando a polpa mineral foi tratada com sulfato de zinco, na dosagem de 7,26 kg/t durante 30 minutos, seguidos de condicionamento com bicarbonato de sódio na dosagem de 3,40 kg/t. Verifica-se na Tabela 4.10 que é possível recuperar $94,8 \%$ do molibdênio contido no pré-concentrado com teor de 53,6\% de Mo (HUCH; VALLEZ, 1975). 
Tabela 4.10 - Balanço de massa e metalúrgico do processo da Pima Mine

\begin{tabular}{ccccc}
\hline Produtos & $\%$ Peso & \%Mo & \% Insol. & \% Rec. Mo \\
\hline Pré-concentrado & 100,0 & 11,7 & 67,6 & 100,0 \\
Concentrado & 33,9 & 53,6 & 35,2 & 94,8 \\
Rejeito & 66,1 & 0,9 & 84,2 & 5,2 \\
\hline
\end{tabular}

\subsubsection{Concentração em separador triboeletrostático}

As operações de enriquecimento de minérios e concentrados de molibdênio (molibdenita) são problemáticas e caras, quando o talco está presente nos minerais de ganga. Reagentes depressores têm sua atividade reduzida em minerais naturalmente hidrofóbicos e com estrutura lamelar, como a molibdenita e o talco. No entanto, a superfície oxidada do talco apresenta características distintas da superfície sulfetada da molibdenita, as quais estão relacionadas com a capacidade de receber ou doar elétrons em seus sítios ativos. Essas diferenças inserem uma vantagem na utilização da separação eletrostática sobre os métodos físico-químicos de separação (flotação) em sistemas contendo o talco e a molibdenita.

O separador triboeletrostático utiliza diferenças de carga elétrica entre as superfícies de minerais, quando em contato com um campo elétrico. O carregamento elétrico das partículas ocorre pelo atrito entre elas, provocado no equipamento. $\mathrm{O}$ mineral com mais alta afinidade por elétrons torna-se carregado negativamente, enquanto o outro mineral torna-se carregado positivamente. Pesquisadores da Universidade de Kentucky (JIANG et al., 1999) realizaram ensaios em escala de bancada em um separador triboeletrostático com dois tipos de minérios de molibdenita fornecidos pela Nanchan Molybdenum Corporation (China). Os ensaios foram conduzidos a seco, sem adição de água ou agentes modificadores de superfície. Após três estágios de processamento foi produzido um concentrado com $28 \%$ de Mo com recuperação metalúrgica de $93 \%$.

\subsubsection{Sulfonato de lignina como depressor de molibdenita}

Com objetivo de desenvolver um sistema de reagentes que propiciassem uma boa separabilidade de minerais insolúveis em ácido (talco e argilas) da molibdenita, pesquisadores do Departamento de Pesquisa Metalúrgica da Anaconda Co., 
descobriram que determinadas quantidades de sulfonato de lignina combinado com leite de cal em meio fortemente alcalino $(\mathrm{pH}>11)$, deprimem a molibdenita, permitindo a separação do talco e argilas por flotação. A Tabela 4.11 apresenta os teores da alimentação, dos concentrados e a recuperação metalúrgica dos ensaios realizados pela Anaconda Co.

Tabela 4.11 - Teores da alimentação, dos concentrados e recuperação metalúrgica do processo da Anaconda Co.

\begin{tabular}{cccc}
\hline Produtos & Ensaios descontínuos & Ensaios locked cycle & Ensaios piloto \\
\hline Alimentação, \% Mo & 27,7 a 48,1 & 27,7 a 48,1 & 35,21 \\
Concentrado, \% Mo & 46,2 a 51,3 & 47 a 48 & 45,87 \\
Recuperação, \% & 91 a 92,7 & 96 a 99 & 91,11 \\
\hline
\end{tabular}

As principais variáveis do processo de flotação como, tempo de residência, dosagem de sulfonato de lignina e $\mathrm{pH}$ do meio, foram determinados em ensaios contínuos em usina piloto. Os melhores teores e recuperações foram alcançados com $8 \mathrm{~min}$ de condicionamento e flotação, usando 1,8 a 2,7 $\mathrm{kg}$ de sulfonato de lignina/t minério e pH 11,9. A Figura 4.19 mostra o fluxograma dos ensaios de laboratório realizados pela Anaconda Co. (HISCOX et al., 1975).

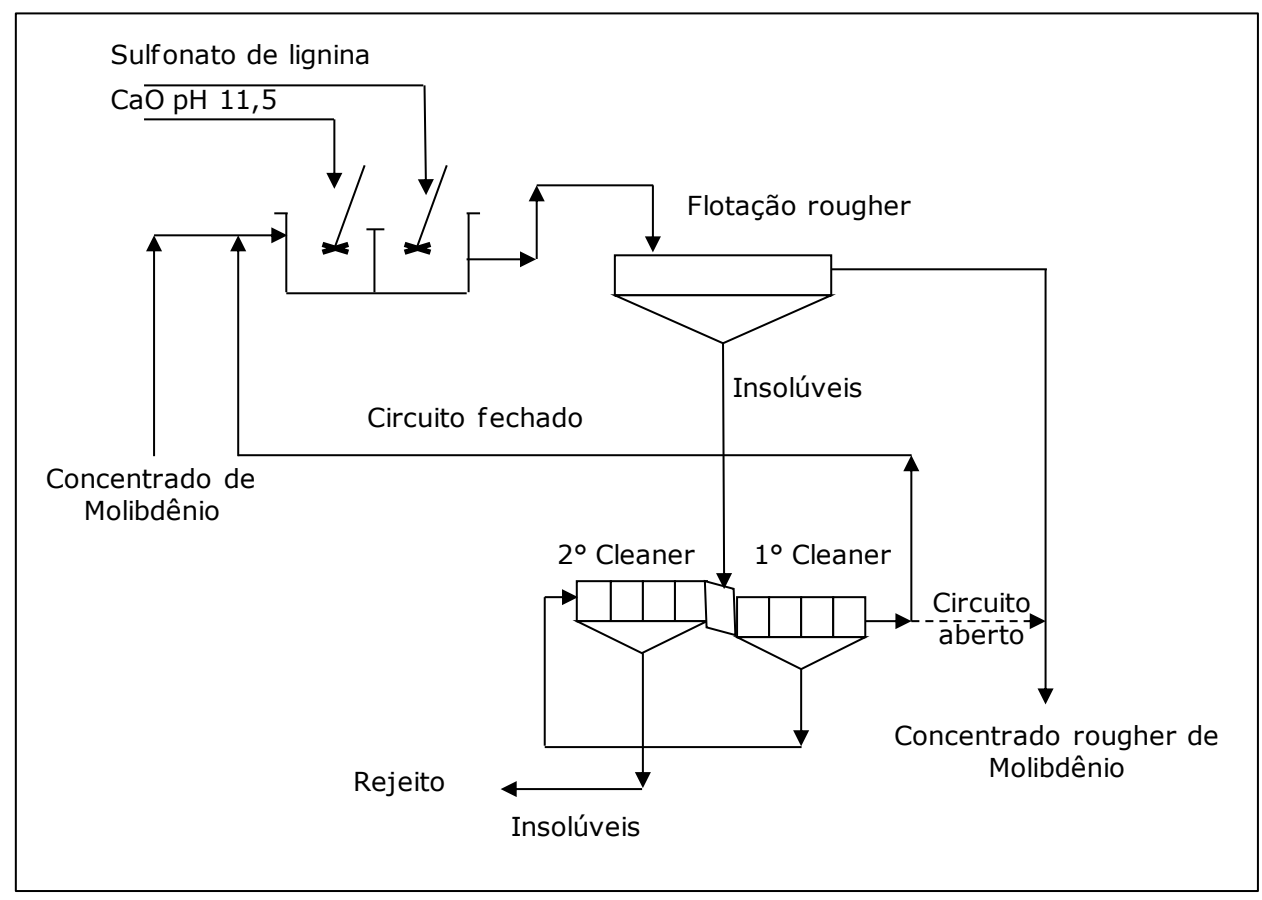

Fonte: Hiscox et al., 1975

Figura 4.19 - Fluxograma utilizado pela Anaconda Co. (circuito aberto e fechado) 
A flotabilidade da molibdenita e do talco é controlada por propriedades de superfície em seus planos de clivagem. Devido à hidrofobicidade comum, inerente aos planos de clivagem destes dois minerais, sua separação por flotação é relativamente mais difícil, quando em comparação com outros sistemas de minerais.

Kelebek et al. (2001) utilizaram diagramas de tensão de adesão para caracterizar a molhabilidade da molibdenita e do talco em soluções de ligno sulfonato de sódio e metil isobutil carbinol-MIBC em pH 7,2. A variação da tensão de adesão, $\gamma_{L V} \cos \theta$, com a tensão interfacial, $\gamma_{L V}$, foi linear. $O$ valor da inclinação $\beta$ para cada caso tem sido utilizado como um indicador da densidade relativa de adsorção. Este estudo mostrou que a densidade relativa de adsorção do ligno sulfonato de sódio na interface sólido/líquido da molibdenita foi significativamente maior que a do talco, por um fator de 2,7. Como a flotabilidade destes dois minerais é controlada principalmente pelas propriedades de superfície de seus planos de clivagem, é de se esperar que a molibdenita seja preferencialmente deprimida em sistemas onde o talco esteja. A partir dos dados experimentais pode-se supor que a ligação hidrofóbica é o mecanismo principal da adsorção do ligno sulfonato de sódio na superfície da molibdenita.

\subsection{ESTUDOS FUNDAMENTAIS PARA SEPARAÇÃO DE MOLIBDENITA E TALCO POR FLOTAÇÃO.}

Normalmente, os bens minerais não são utilizados como lavrados, havendo necessidade de um prévio beneficiamento para sua concentração. Esse beneficiamento de minerais consiste na separabilidade do mineral de minério dos minerais de ganga, por meios de processamento físico (processos gravíticos e separação magnética) ou por processamento físico-químico, como a flotação. A escolha do método de concentração depende essencialmente da definição do tamanho abaixo do qual as partículas dos minerais de interesse encontram-se suficientemente liberadas das espécies de minerais de ganga (CHAVES, 2006).

Os métodos físicos de concentração (gravíticos e magnéticos) não requerem a adição de reagentes, mas sua aplicação se restringe a faixas granulométricas mais grossas e geram concentrados mais impuros. Para a produção de concentrados de alto teor e baixos níveis de impurezas, a partir de minérios que requerem cominuição 
em granulometria fina, no sentido de liberarem os minerais de interesse, normalmente utiliza-se a operação de flotação.

A flotação é o principal método de concentração de minerais e é baseada nas diferentes propriedades físico-químicas de superfície dos minerais presentes em uma suspensão aquosa e que podem ser arrastados por um fluxo de ar. A seletividade do processo requer a adição de reagentes químicos que induzem a propriedade diferenciadora (hidrofilicidade ou hidrofobicidade).

Essas propriedades hidrofílicas e hidrofóbicas determinam a flotabilidade natural dos minerais e estão relacionadas diretamente com sua polaridade. Os minerais apolares são simétricos em sua estrutura, não trocam elétrons dentro de suas moléculas, não se dissociam em íons e são geralmente inativos. Os principais minerais naturalmente hidrofóbicos são a molibdenita, o talco, o carvão, o enxofre e a grafita. Ao contrário, os minerais polares são caracterizados por uma estrutura assimétrica, trocam ou compartilham elétrons em suas ligações e têm uma grande reatividade química. A maioria das espécies minerais é hidrofílica e são representadas pelos grupos dos sulfetos, carbonatos, óxidos, silicatos e sais (CHAVES; LEAL FILHO; BRAGA, 2010; LEJA, 1982).

\subsubsection{O mineral molibdenita}

A estrutura cristalina da molibdenita mostrada esquematicamente na Figura 4.20, consiste em uma sequencia de camadas em que cada átomo de molibdênio é cercado por seis átomos de enxofre, em ápices de um prisma triangular; esses prismas compartilham as arestas verticais entre si para formar uma camada de SMo-S. O cristal é formado pela repetição dessas camadas completas, uma acima da outra, de forma a constituir uma estrutura cristalográfica com configuração hexagonal. Dentro de cada camada de S-Mo-S, a ligação covalente é predominante, apesar de Pauling ter atribuído a presença de brilho metálico a alguma ligação metálica. Em contraste, as camadas de S-Mo-S das arestas dos prismas triangulares são mantidas juntas por fracas ligações de van der Walls, gerando grandes distâncias enxofre-enxofre entre as camadas. Estas ligações são facilmente quebradas, dando origem a uma clivagem perfeita ao longo do plano 0001 (CHANDER; FUERSTENAU, 1972). 
A molibdenita exibe uma estrutura cristalina laminar baseada em dois tipos de ligações químicas, ou seja, ligações covalentes entre S-Mo, cuja quebra gera sítios em sua superfície com alta energia, conhecido como "bordas" e interações de van der Walls entre as camadas S-Mo-S, cuja quebra gera sítios de baixa energia conhecido como "face". Esses sítios distintos fazem com que a molibdenita apresente heterogeneidade na sua superfície intrínseca dada pela proporção entre faces e bordas (CASTRO; CORREA, 1995).

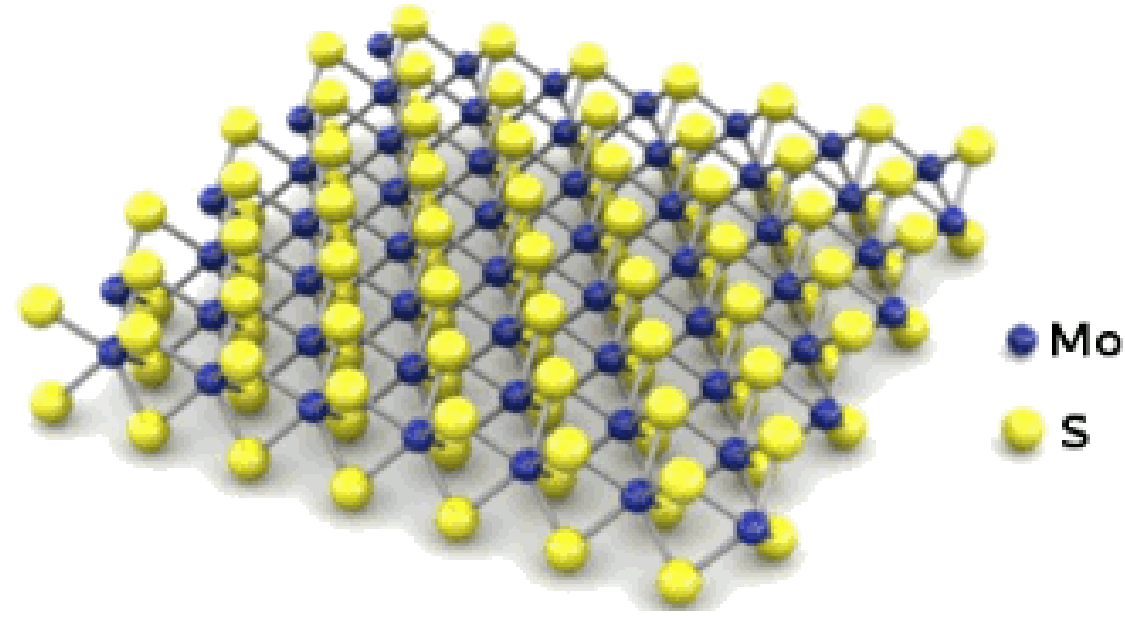

Fonte: Benameur et al. (2011)

Figura 4.20 - Estrutura do cristal de molibdenita, $\mathrm{MoS}_{2}$

\subsubsection{O mineral talco}

O talco quimicamente é um silicato de magnésio hidratado $\left(\mathrm{Mg}_{3} \mathrm{Si}_{4} \mathrm{O}_{10}(\mathrm{OH})_{2}\right)$ com uma composição química teórica de 31,7\% de $\mathrm{MgO}, 63,5 \% \mathrm{SiO}_{2}$ e 4,8\% $\mathrm{H}_{2} \mathrm{O}$. Embora a composição do talco permaneça próxima da fórmula geral, algumas substituições podem ocorrer. Pequenas quantidades de ferro, manganês e alumínio podem substituir o magnésio. Quando grandes quantidades de alumínio suŁstituem o magnésio do mineral, ele é conhecido como pirofilita. O talco é, geralmente, de coloração verde, branco, cinza, marrom ou incolor. É um mineral translúcido com brilho perolado. Dentre todos os minerais conhecidos é o mais macio e lhe é atribuída uma dureza de 1 na escala de Mohs. A estrutura cristalina do talco é monoclínica, com lamelas semelhantes às micas e sua clivagem é perfeita entre os planos de suas lamelas que estão unidas por ligações de van der Waals. Esta característica é responsável pela maciez extrema e a sensação untosa, como um sabão (KING, 2012). 
A estrutura básica do cristal de talco é composta por uma camada de octaedros de magnésio-oxigênio/hidroxila, prensada entre duas camadas de tetraedros de silício-oxigênio (Figura 4.21). A face superficial do talco não contém grupos hidroxila ou íons ativos, tornando-a com características hidrofóbica e inerte. $\mathrm{O}$ talco é praticamente insolúvel em água e álcalis e ácidos fracos. Não é explosivo e nem inflamável e tem pouca reatividade química e afinidade por produtos orgânicos; ou seja, é organofílico. Sua estrutura equilibrada e neutra pode suportar temperaturas de até $900^{\circ} \mathrm{C}$. Seu ponto de fusão é de $1500^{\circ} \mathrm{C}$ (IMERYS, 2012).

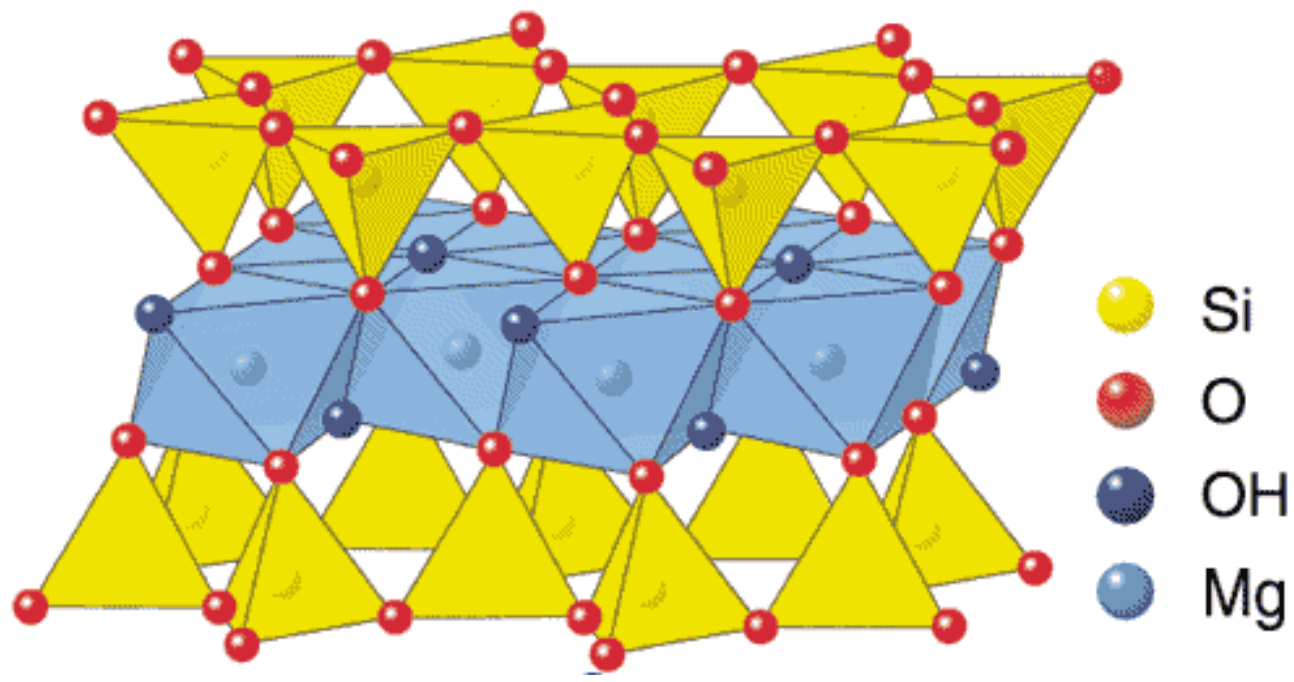

Figura 4.21 - Estrutura do cristal de talco, $\mathrm{Mg}_{3} \mathrm{Si}_{4} \mathrm{O}_{10}(\mathrm{OH})_{2}$.

\subsubsection{A flotabilidade natural da molibdenita e do talco}

Chander et al (1975) fizeram uma revisão quanto às teorias existentes sobre a flotabilidade natural de minerais hidrofóbicos. Na primeira teoria, Gaudin et al (1957) propuseram que a flotabilidade é resultante da formação de alguma fratura ou de superfície de clivagem sem o rompimento de ligações interatômicas, à exceção de ligações residuais (van der Walls). Derjaguin e Shukakidse (1960) propuseram uma teoria para flotação coletiva de minerais hidrofóbicos baseada na clássica teoria de estabilidade coloidal DLVO, onde os critérios para flotação envolvem a constante de Hamaker e as propriedades da dupla camada elétrica. Arbiter et al. (1974) propuseram que o potencial zeta e a flotabilidade estão bem correlacionados para o mineral estibnita e que está em acordo com o critério de flotação de DerjaguinShukakidse, entretanto não se aplica para molibdenita e parafina.

Chander e Fuerstenau (1972) descobriram uma correlação qualitativa entre potencial zeta e flotabilidade, em tubo de Hallimond, para molibdenita. A superfície 
da molibdenita tende a sofrer oxidação $\left(\mathrm{MoO}_{3}\right)$ e hidrólise do molibdênio (III) produzindo, nas bordas da molibdenita, espécies de molibdatos, como $\mathrm{HMoO}_{4}^{-} \mathrm{e}$ $\mathrm{MoO}_{4}{ }^{2-}$, promovendo o aparecimento de cargas negativas nessas bordas. Em meio ácido, tem-se uma densidade de carga menor, devido à presença preferencial do $\mathrm{HMoO}_{4}{ }^{-}$; essas cargas aumentam à medida em que vai ocorrendo a transformação do $\mathrm{HMoO}_{4}^{-}$para $\mathrm{MoO}_{4}{ }^{2-}$, com o aumento do $\mathrm{pH}$. Daí atribuir-se principalmente às bordas a carga elétrica superficial da molibdenita. Foi observado que a presença desses íons, possivelmente adsorvidos, promove o aumento da negatividade do potencial zeta e diminui a recuperação do mineral.

A oxidação da superfície da molibdenita pode ser removida por meio da lixiviação do mineral com solução alcoólica de $\mathrm{KOH}$. Os autores observaram que após esse tratamento de superfície, os valores dos ângulos de contato foram mais elevados do que os observados para o mineral naturalmente oxidado, sem tratamento. Esse resultado mostrou que, possivelmente, somente as bordas dos cristais de molibdenita contribuíram na variação da hidrofobicidade do mineral.

Recentemente, López-Valdivieso et al. (2012), influenciado pelo estudo de Chander e Fuerstenau (1972), aprofundaram o estudo das propriedades de superfície da molibdenita em escala nanométrica, por meio de microscopia de força atômica (AFM); foram estudados os efeitos do $\mathrm{pH}$ e da presença de $\mathrm{Ca}^{2+}$ na flotabilidade e nas propriedades eletrocinéticas da molibdenita, com base na avaliação da textura da superfície do mineral. Concluíram que as faces da molibdenita são naturalmente heterogêneas, compostas por microcristais de $\mathrm{MoS}_{2}$ com nano faces e nano bordas. Os autores constataram, ainda, que as faces não são completamente hidrofóbicas, possivelmente devido à presença das nano bordas, que geram sítios hidrofílicos; essas nano bordas têm cargas elétricas negativas, que aumentam com o pH e impedem a interação das bolhas de ar com a superfície (faces) dos cristais de molibdenita e promovem, consequentemente, a baixa flotabilidade da molibdenita.

Chander, Wie e Fuerstenaul (1975) realizaram um estudo sobre a flotabilidade natural e as propriedades de superfície de alguns sólidos naturalmente hidrofóbicos como a molibdenita e o talco e fizeram uma comparação entre suas propriedades (Tabela 4.12). Uma parte da superfície desses minerais é gerada pela ruptura das ligações de van der Walls e esta nova superfície tem natureza hidrofóbica e é responsável pela flotabilidade natural. O comportamento desta superfície é 
essencialmente função do $\mathrm{pH}$, podendo ser quimicamente modificado por soluções ácidas ou alcalinas. Como foi sugerido por Arbiter et al. (1974), esta superfície pode ser análoga à interface água/ar. O restante da superfície é formado por ruptura das ligações covalentes. Os sítios onde essas ligações são rompidas são altamente reativos e quando expostos à água podem formar grupos hidrofílicos oxidados ou orientar fortemente as moléculas de água. A carga de superfície dos grupos hidrofílicos formados pode variar com o pH da solução e dar origem a propriedades específicas desses minerais.

Tabela 4.12 - Propriedades de sólidos hidrofóbicos (molibdenita e talco)

\begin{tabular}{ccc}
\hline PROPRIEDADES & MOLIBDENITA & TALCO \\
\hline Tipo de estrutura & Camadas & Camadas \\
Tipos de ligações rompidas na clivagem & van der Walls & van der Walls \\
Faixa do pH na qual o potencial zeta é constante & $6,5-9$ & $6,5-8,5$ \\
$\begin{array}{c}\text { Correlação qualitativa entre flotabilidade e potencial zeta } \\
\text { Correlação quantitativa entre flotabilidade e potencial } \\
\text { zeta (baseado na teoria DLVO) }\end{array}$ & Sim & Pobre \\
$\begin{array}{c}\text { Correlação qualitativa entre o potencial zeta e os } \\
\text { ângulos de contato }\end{array}$ & Não & - \\
Faixa do pH na qual o ângulo de contato é constante & $2-9$ & - \\
Propriedades anisotrópicas distintas & Sim & Sim \\
Grupos prováveis de superfície hidrofílica & $>$ MoS $_{x} \mathrm{O}_{\mathrm{y}} \mathrm{H}_{z}^{-n}$ & $>$ MOH \\
\hline
\end{tabular}

A superfície anisotrópica parece ser uma característica inerente aos sólidos mais hidrofóbicos. Isto dá origem a propriedades dependentes da forma das partículas desses materiais, isto é, partículas de formas diferentes podem ter propriedades diferentes, devido às diferentes razões de superfície hidrofílica e hidrofóbica. A natureza anisotrópica dessas partículas também explica a pobre correlação entre o potencial zeta, os ângulos de contacto e a flotabilidade.

Outra característica dos sulfetos naturalmente hidrofóbicos é que, quando oxidados formam espécies aniônicas que permanecem como sítios individuais. Em contraste com isso, os sulfetos não naturalmente flotáveis, formam cátions que podem se hidrolisar e formar óxidos insolúveis (ou hidróxidos) sobre a superfície da partícula. Estes óxidos podem crescer como manchas na superfície da partícula tornando-a hidrofílica. 
O mineral talco tem uma natureza físico-química complexa, pois sua superfície é composta por dois sítios diferentes: a face de clivagem basal e a borda. A face é constituída por uma superfície de siloxano tetraédrica com ligações Si-O-Si inertes e, portanto, de carga neutra e caráter hidrofóbico. Nas bordas, as lamelas de sílica tetraédrica e de brucita octaédrica estão rompidas, resultando em ligações quebradas de grupos hidroxila $(-\mathrm{OH})$ que transmitem um caráter hidrofílico. Devido a essas características, as propriedades na superfície do talco (face ou borda) são completamente diferentes. O desenvolvimento de cargas na superfície do talco em sistemas aquosos e, consequentemente, as propriedades de dupla camada elétrica da superfície, em função do pH e da força iônica, foram estudadas por Morris (1996).

As propriedades de superfície do talco são controladas pelas fracas forças de van der Waals existentes entre as lamelas de talco e as ligações eletrostáticas dentro das camadas. A fácil clivagem das camadas resulta no predomínio da superfície da face em relação à superfície da borda (FUERSTENAU et al., 1988; GOMES; OLIVEIRA, 1991). As cargas de superfície do talco influenciam a sua flotabilidade por meio de interações entre os sólidos hidrofóbicos e as bolhas de ar. Um aumento na carga superficial do talco pode tornar sua superfície de maior molhabilidade e, consequentemente, reduzir sua hidrofobicidade (FOKKINK; RALSTON, 1989).

Conforme mencionado na introdução, existe uma carência de trabalhos na literatura sobre a separabilidade de molibdenita e talco e sobre fenômenos de superfície que atuam nas suas propriedades e, consequentemente, na separabilidade.

\subsubsection{Reagentes modificadores no processamento mineral}

Os reagentes modificadores são considerados os mais importantes produtos químicos no processamento mineral e são os responsáveis pelo controle específico da ação de um coletor sobre a superfície de um mineral. Os reagentes modificadores, dependendo das condições de uso, podem ser considerados agentes depressores ou ativadores dos processos de flotação. A utilização de reagentes modificadores permite a separação seletiva individual de sulfetos metálicos, como, chumbo, zinco e cobre de um minério sulfetado complexo. Da mesma forma é 
possível separar seletivamente minerais que contêm cálcio, como a calcita, a fluorita e a scheelita uns dos outros (BULATOVIC, 2007).

Nos processos de flotação, o reagente coletor é utilizado para adsorver na superfície dos minerais de interesse (no caso de flotação direta), tornando-os hidrofóbicos na interface ar/água, permitindo assim a sua captura pelas bolhas de ar. Por outro lado, um reagente depressor deve ser adsorvido na superfície dos minerais de ganga, tornado-a hidrofílica, agindo como uma barreira protetora à adsorção de coletor. Os reagentes depressores devem possuir grupos funcionais em suas moléculas que tenham afinidade com a água e que não concorram com a ação do coletor (LIN; BURDICK, 1988).

Os reagentes depressores são usados para melhorar as condições de seletividade, isto é, aumentar o teor do concentrado. Sua principal finalidade é inibir a adsorção do coletor nos minerais que não se deseja flotar, evitando a hidrofobização das superfícies dos mesmos ou promovendo a hidrofilização das mesmas, no caso de minerais naturalmente hidrofóbicos. Sua adição e ação devem ser anteriores à adição do coletor (BALTAR, 2010).

Os reagentes modificadores podem ser orgânicos ou inorgânicos e uma classificação, com subgrupos, encontra-se apresentado na Figura 4.22.

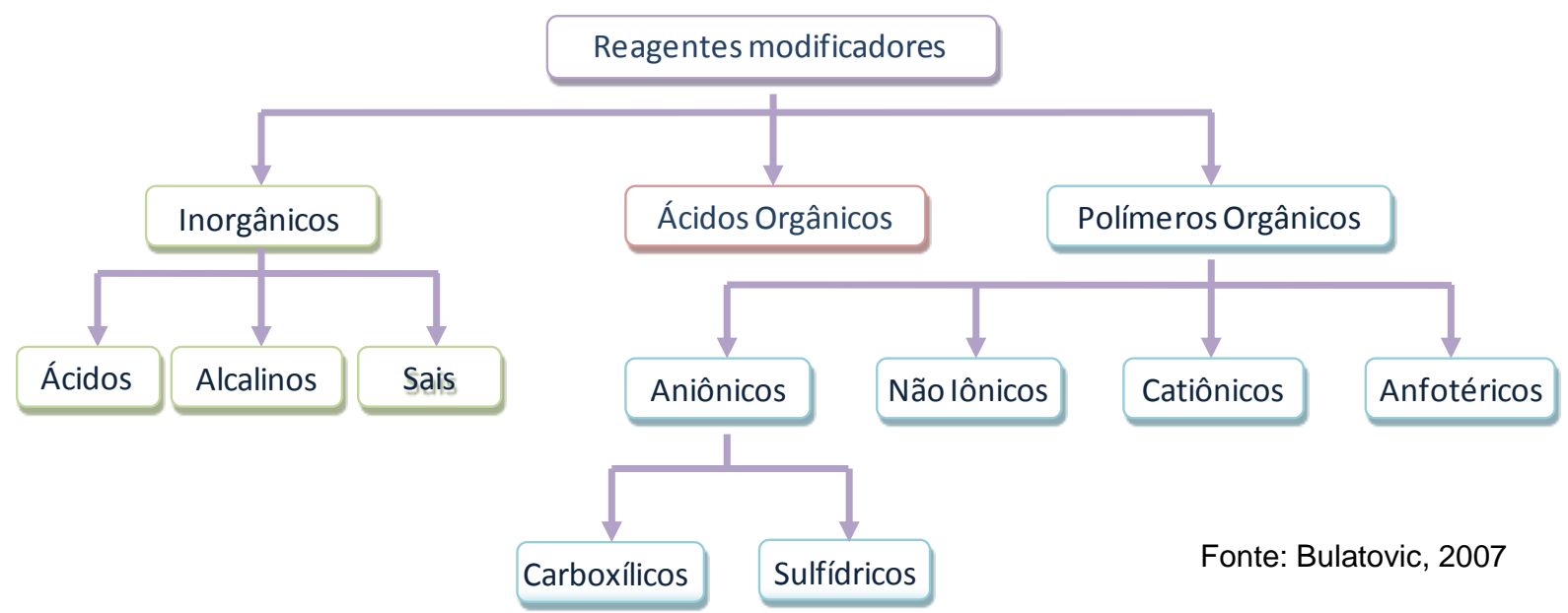

Figura 4.22 - Classificação dos reagentes modificadores 
A seguir será apresentada uma revisão sobre alguns reagentes modificadores de superfície utilizados na indústria mineral, com ênfase naqueles aplicados em processos de separação relacionados aos minerais molibdenita e talco.

\subsubsection{Goma guar}

Goma guar é um polímero não-iônico de peso molecular da ordem de 250.000 Dal com cerca de 450 unidades básicas, formadas por moléculas de galactose e manose. No monômero (unidade básica) é importante destacar o posicionamento dos grupos $-\mathrm{OH}$, pois se encontram na posição cis (mesmo lado), característica que permite e reforça ligações por meio de pontes de hidrogênio com outros compostos (PEARSE, 2005). A Figura 4.23 mostra a fórmula química do monômero básico da goma guar.
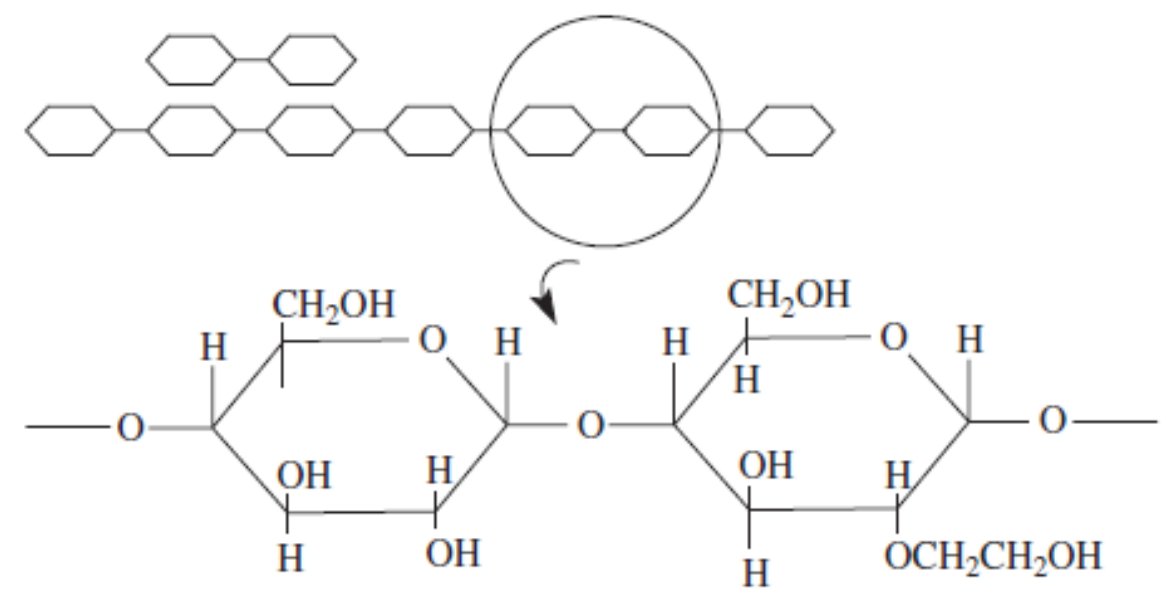

Figura 4.23 - Monômero básico da goma guar

Rath, Laskowski e Subramanian (1999) realizaram estudos eletrocinéticos, de adsorção e de flotação com objetivo de verificar a interação da goma guar com minerais hidrofóbicos e lamelares, como o talco, a mica e o grafite. Ficou demonstrado neste estudo que a densidade de adsorção da goma guar sobre os minerais hidrofóbicos é basicamente independente do $\mathrm{pH}$. As isotermas de adsorção indicaram que a densidade de adsorção aumenta com o aumento da concentração da goma guar e a magnitude dessa adsorção sobre os minerais hidrofóbicos pode ser organizada na seguinte sequencia: talco > grafite $>$ mica. $\mathrm{O}$ efeito do tamanho de partícula indicou que a maior adsorção ocorre na fração mais grossa e, consequentemente, está relacionada a um aumento da relação faces:bordas. Medidas eletrocinéticas indicaram que os pontos isoelétrico (iep) desses minerais 
encontram-se entre pH 2-3 e a adição de goma guar diminuiu os valores negativos da mobilidade eletroforética na mesma proporção da concentração da goma guar, sem qualquer mudança nos valores iep. A flotabilidade desses minerais na presença da goma guar é diminuída, na mesma sequencia que foi observada nos estudos de adsorção.

A densidade de adsorção diminui com o tamanho da partícula, devido à diminuição da relação face:borda nas frações mais finas. Existe maior adsorção nas frações mais grosseiras, que é atribuída à maior hidrofobicidade das faces perante as bordas. Estes resultados indicam erroneamente que a ligação hidrofóbica não é o principal mecanismo que rege a adsorção da goma de guar, mesmo no caso dos minerais hidrofóbicos. Os mecanismos de adsorção são regidos por ligações de pontes de hidrogênio e interações químicas (RATH; SUBRAMANIAN; LASKOWSKI, 1997).

\subsubsection{Dextrina}

Dextrina é um polímero solúvel em água, sem propriedades de eletrólito (não se dissocia) e com fórmula geral de $\left(\mathrm{C}_{6} \mathrm{H}_{1005}\right)_{n}$. Seu peso molecular varia de $800 \mathrm{a}$ $79.000 \mathrm{Da}$. A dextrina é obtida como um produto intermediário da hidrólise parcial do amido, sendo conhecida por seu monômero que tem a mesma estrutura do monômero de amido. A Figura 4.24 mostra a fórmula estrutural do monômero do amido e da dextrina, usados para representar a localização dos átomos de carbono. A principal diferença entre a estrutura da molécula de dextrina e da molécula de amido reside nas ligações dos monômeros, isto é, durante a reação de dextrinização as ligações 1-4 de monômeros na molécula tendem a desaparecer parcialmente e as ligações 1-6 tendem a ocorrer formando a molécula de dextrina (WIE; FUERSTENAU, 1974). 


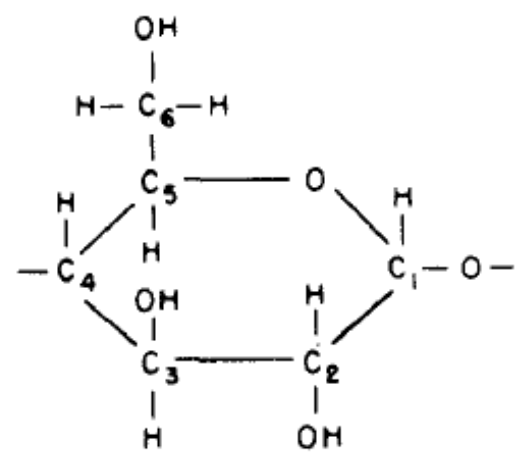

Figura 4.24 - Monômero básico do amido e da dextrina

Wie e Fuerstenau (1974) investigaram a ação da dextrina sobre as propriedades de superfície da molibdenita com medições do potencial zeta, ensaios de adsorção, medição do ângulo de contato e flotação em tubo de Hallimond. Os resultados desta investigação evidenciaram que a adsorção da dextrina na molibdenita ocorre através da interação física com a superfície, possivelmente devido à ligação hidrofóbica. O mecanismo de ligação hidrofóbica é de acordo com a magnitude da energia livre de adsorção, que foi estimada em $-5,4 \mathrm{kcal} / \mathrm{mol}$ de monômero de dextrina. O potencial zeta da molibdenita foi reduzido em magnitude absoluta, devido à adsorção de moléculas de dextrina na superfície do mineral. A adsorção da dextrina na molibdenita é independente do $\mathrm{pH}$ e segue uma isoterma tipo Langmuir. O ângulo de contato formado pela bolha de ar na superfície da molibdenita e a sua flotabilidade em tubo de Hallimond, diminuíram com o aumento da concentração de dextrina. Este efeito parece depender muito mais da concentração de dextrina do que do $\mathrm{pH}$. A Tabela 4.13 mostra o valor do ângulo de contato e recuperação da molibdenita nos ensaios de flotação em tubo de Hallimond em função da concentração de dextrina e do pH.

Tabela 4.13 - Recuperação de molibdenita em função da concentração de dextrina

\begin{tabular}{cccc}
\hline \multirow{2}{*}{ Conc. dextrina $(\mathrm{mg} / \mathrm{L})$} & \multicolumn{2}{c}{ Ângulo de contato } & \multirow{2}{*}{ Recuperação (\%) $\mathrm{pH} \mathrm{3,8}$} \\
\cline { 2 - 3 } & $\mathrm{pH} 3,8$ & $\mathrm{pH} \mathrm{9,4}$ & 92 \\
0,2 & $86^{\circ}$ & $83^{\circ}$ & 18 \\
0,83 & $67^{\circ}$ & $63^{\circ}$ & 9 \\
1,67 & & & 8 \\
8,3 & $42^{\circ}$ & $45^{\circ}$ & 2 \\
16,7 & $0^{\circ}$ & $0^{\circ}$ & 1,6 \\
50 & & & 1,6 \\
100 & & & 1,5 \\
\hline
\end{tabular}


Beaussart et al. (2012) estudaram a adsorção de três tipos de dextrina modificada (TY, CM e HP) na superfície da molibdenita utilizando imagens de AFM (Microscópio de força atômica), medições de ângulos de contato e flotabilidade em célula Denver. Alguns resultados desse trabalho são apresentados na Tabela 4.14. A densidade de adsorção é representada por $\Gamma\left(\mathrm{mg} / \mathrm{m}^{2}\right)$.

Tabela 4.14 - Adsorção de dextrina em função do peso molecular do polímero

\begin{tabular}{cccc}
\hline Polímero & Peso molecular $(\mathrm{Da})$ & $\Gamma\left(\mathrm{mg} / \mathrm{m}^{2}\right)$ & Recuperação (\%) \\
\hline Molibdenita pura & - & - & $97 \pm 1$ \\
Dextrina TY & 5.000 & 1,06 & $54 \pm 1$ \\
Dextrina CM & 34.000 & 1,12 & $40 \pm 1$ \\
Dextrina HP & 64.000 & 1,63 & $45 \pm 1$ \\
\hline
\end{tabular}

Foi observado que a adsorção dos diferentes tipos de dextrina ocorre de maneira aleatória na superfície da molibdenita, porém a quantidade adsorvida tem relação direta com o peso molecular do polímero. Os polímeros estudados não reduziram significativamente a flotabilidade da molibdenita, embora tenham sido observadas diferenças na ação como depressores. A ação de depressão foi crescente na sequência dextrina CM, dextrina HP e dextrina TY.

Beattie et al. (2006a) realizaram um estudo sobre o efeito depressor de polissacarídeos (amido HP e dextrina WY) e poliacrilamidas (polímero H) sobre o talco em presença de sulfetos minerais de $\mathrm{Ni}$ e $\mathrm{Cu}$. Foram estudados três polímeros de diferentes variedades químicas e pesos moleculares. Os testes de flotação revelaram uma eficiência decrescente na ação depressora dos polímeros sobre o talco, na seguinte ordem: amido HP > polímero $\mathrm{H}>$ dextrina $\mathrm{WY}$, para um sistema de mineral puro. O amido HP, por ser um polímero de alto peso molecular (706.000 Da), apresentou maior eficiência na depressão do talco do que a dextrina WY (9.260 Da). Essa particularidade se reflete nas diferentes quantidades de amido $(4,82$ $\left.\mathrm{mg} / \mathrm{m}^{2}\right)$ adsorvidas na superfície do talco, comparado com a dextrina $\left(0,92 \mathrm{mg} / \mathrm{m}^{2}\right)$, conforme apresentado por Beattie et al. (2006b). Em termos de seletividade, para sistema talco/sulfetos, a eficiência de depressão do talco ocorre na seguinte ordem: dextrina $\mathrm{WY}>$ polímero $\mathrm{H}>$ amido HP. A melhor seletividade da dextrina é atribuída à sua reduzida adsorção na superfície dos minerais sulfetados, quando comparada ao talco. 


\subsubsection{Carboximetil celulose (CMC)}

No grupo dos reagentes modificadores, a carboximetil celulose (CMC) é o polímero mais aplicado na flotação de minerais, sendo utilizado na depressão de talco e de minerais portadores de cálcio e magnésio como calcita, dolomita, fluorita e apatita.

A carboximetil celulose é obtida pela reação do ácido monocloroacético ou seu sal de sódio com a celulose alcalina. A celulose é um polímero linear derivado da glicose e suas principais fontes são madeira e algodão. Alguns dos grupos $-\mathrm{OH}$ da celulose são substituídos por $-\mathrm{OCH}_{2} \mathrm{COO}^{-} \mathrm{Na}^{+}$na fórmula de glicose, conforme mostrado na fórmula estrutural na Figura 4.25. Três parâmetros são importantes para determinar o desempenho da CMC: (i) pureza, alguns produtos têm cloreto de sódio residual proveniente da reação de formação; (ii) peso molecular, avaliado em função da viscosidade da solução a 1 ou $2 \%$; (iii) número médio de grupos éter (carboximetil) substituídos por unidade de glicose (conhecido como o grau de substituição - GS), que varia geralmente de 0,65 a 1,0. Cada celulose tem três grupos de $\mathrm{OH}$ por unidade de glicose e, se um desses grupos é substituído, então o GS assume o valor 1,0 (PEARSE, 2005).

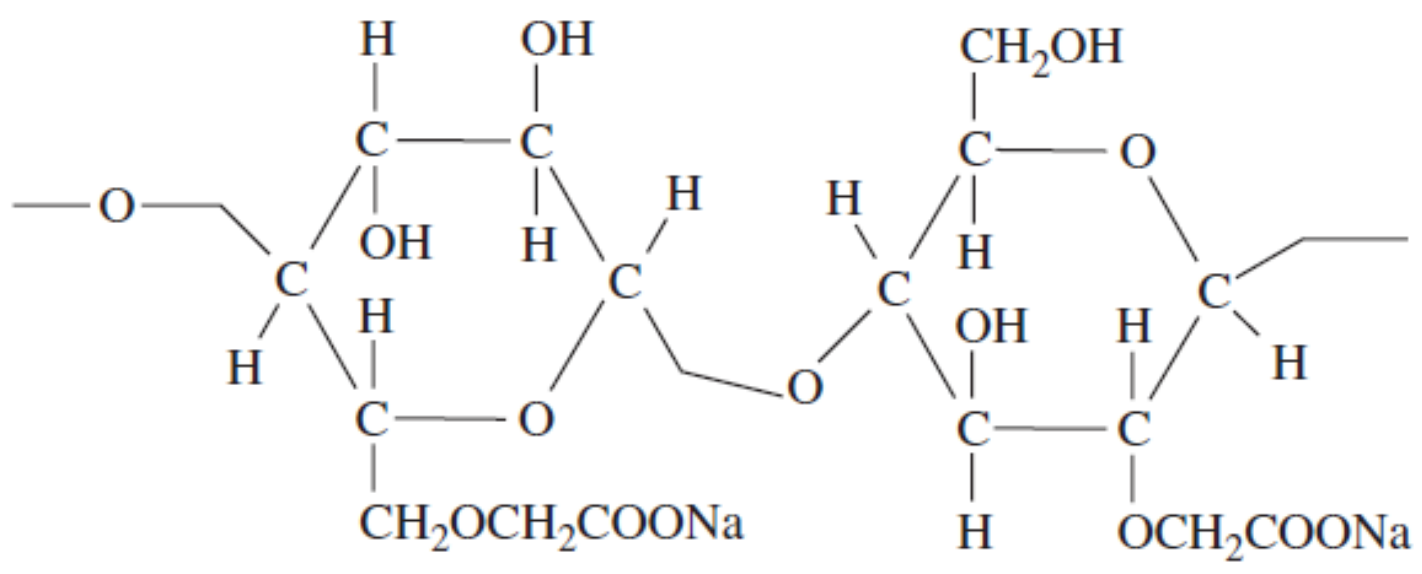

Figura 4.25 - Estrutura da carboximetil celulose (CMC)

A CMC é produzida com diferentes pesos moleculares que variam de 50.000 a 800.000 Da e pode sofrer modificações em sua estrutura para melhorar sua ação depressora sobre minerais portadores de magnésio, como o talco (BULATOVIC, 2007).

No estudo realizado por Gomes (1988), ficou evidenciado que o efeito depressor da CMC sobre a flotabilidade do talco, na presença e ausência de 
xantato, é maior na faixa ácida de $\mathrm{pH}$ e que em concentrações elevadas o comportamento da CMC é invertido, diminuindo sua ação depressora. A presença de cloreto de alumínio na polpa mineral aumenta a depressão do talco, devido ao grande aumento da densidade de adsorção no intervalo de $\mathrm{pH}$ entre 4 e 5 . Esse aumento na densidade de adsorção foi interpretado pela autora como decorrente da maior adsorção do alumínio na forma de hidróxidos iônicos predominantes nesta faixa de $\mathrm{pH}$.

De acordo com Baltar (2010) existem duas possibilidades para adsorção da molécula do CMC na superfície de um mineral: (i) por meio de interações do grupo hidroxila $\left(-\mathrm{OH}^{-}\right)$que adsorve nos sítios hidroximetálicos; (II) por meio do grupo carboxila (-COO`) que, além de adsorver nos sítios hidroximetálicos, também pode interagir com cátions metálicos da superfície. Nas duas situações, o mecanismo de adsorção é dependente do pH da polpa, uma vez que a CMC é considerada um reagente depressor com propriedades aniônicas.

Liu et al. (2006) compararam a ação depressora da CMC (carboximetil celulose), da CMS (carboximetil amido) e da dextrina sobre a flotabilidade do talco. A interação desses três polissacarídeos com diferentes grupos funcionais e pesos moleculares foi investigada por meio da densidade de adsorção, flotabilidade e medições electrocinéticas. Os resultados desta pesquisa mostraram que: (i) a densidade de adsorção é independente do $\mathrm{pH}$ e suas isotermas apresentaram comportamento do tipo Langmuir; (ii) a densidade de adsorção na superfície do talco é maior no sentido CMC > CMS > dextrina, devido ao maior peso molecular e a presença de grupos carboxila na CMC e CMS em relação à dextrina; (iii) a densidade de adsorção é reduzida com diminuição do tamanho das partículas, devido à diminuição da relação faces:bordas nas frações mais finas; (iv) a flotabilidade do talco é diminuída em maior extensão pela CMC quando comparada com a dextrina; (v) postula-se que os mecanismos de adsorção são regidos por ligações de hidrogênio e interações química. 


\subsubsection{4 Ácido húmico}

As substâncias húmicas constituem uma fração grande (60-70\%) da matéria orgânica contida em solos e 30-50\% da matéria orgânica das águas superficiais; possivelmente, são as mais abundantes macromoléculas existentes na terra (2-3 x $10^{10}$ t). Carbono, oxigênio, hidrogênio e pequenas quantidades de nitrogênio, fósforo e enxofre são os principais constituintes das substâncias húmicas. O ácido húmico é o principal constituinte das substâncias húmicas, tem um peso molecular de 5.540 Da com uma fórmula empírica de $\mathrm{C}_{308} \mathrm{H}_{328} \mathrm{O}_{90} \mathrm{~N}_{5}$. Sua estrutura molecular é composta por benzeno com resíduos de piridina, pirrole e furano. Apesar de várias pesquisas terem sido realizadas ao longo das últimas décadas com a finalidade de estabelecer a estrutura do ácido húmico, ela ainda não se encontra perfeitamente estabelecida (JONES; BRYAN, 1998).

Pesquisadores da Kennecott Minerals Company investigaram o uso de ácido húmico na recuperação da molibdenita por flotação (LAI; STONE; RIMMASCH, 1984). Foram realizadas duas séries de experimentos em uma célula de microflotação. Na primeira série de experimentos verificou-se a influência da concentração do ácido húmico na recuperação de molibdenita e na segunda série a influência do $\mathrm{pH}$. Os resultados indicaram que a flotabilidade da molibdenita diminui, a medida que a concentração de ácido húmico aumenta (Figura 4.26). De maneira análoga, a flotabilidade é reduzida com o aumento de $\mathrm{pH}$.

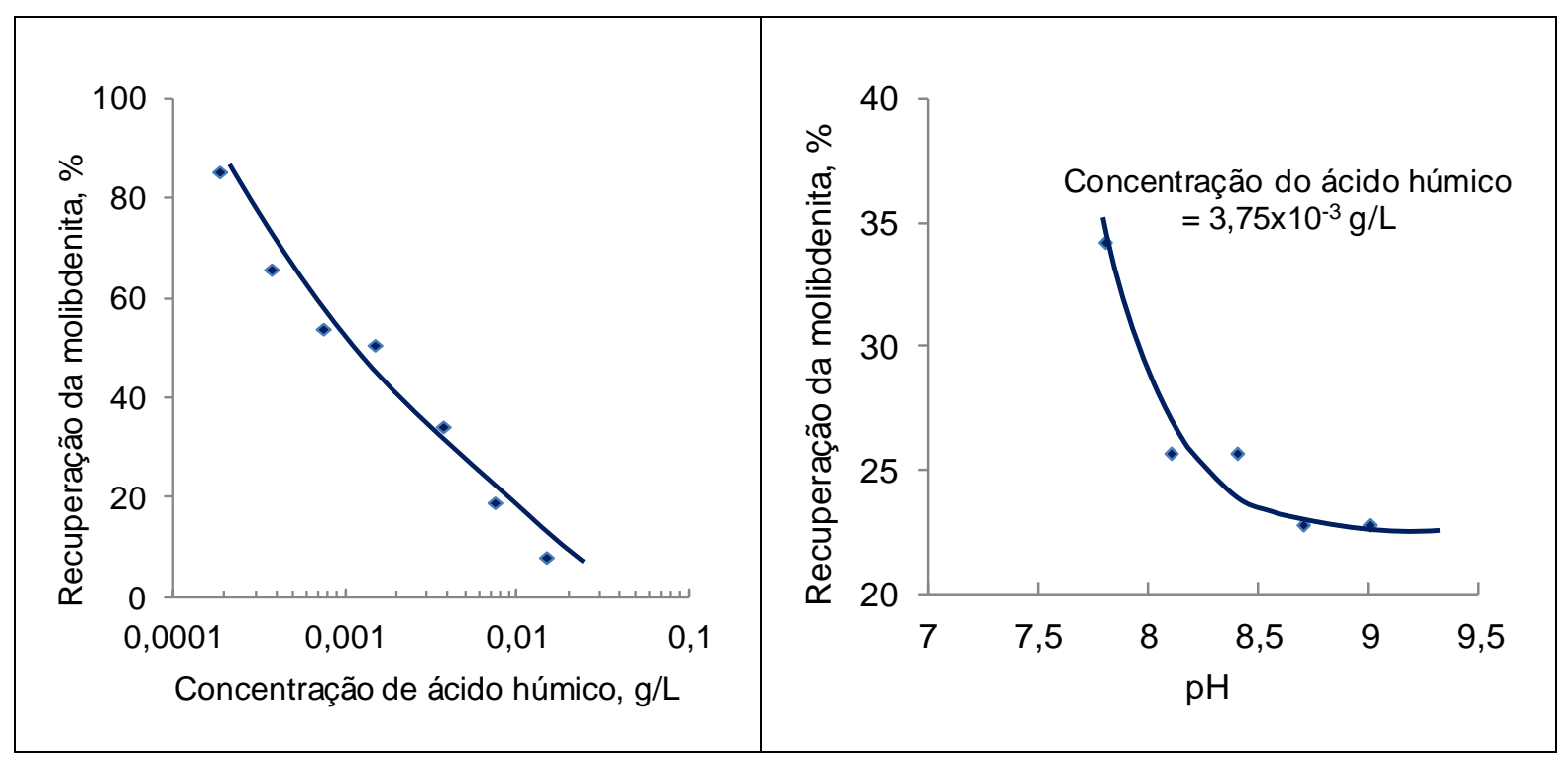

Figura 4.26 - Efeito da concentração de ácido húmico e do pH na recuperação da molibdenita (adaptada de LAl; STONE; RIMMSCH, 1984) 
O efeito da adsorção do ácido húmico na hidrofobicidade da molibdenita é dependente do $\mathrm{pH}$. À medida que o pH aumenta, a solubilidade e a atividade do ácido húmico também aumentam, acarretando diminuição na recuperação.

Pawlik (2005) estudou o efeito de vários polímeros (não-iônicos e aniônicos) de baixo peso molecular (100.000 Da) sobre as propriedades de superfície de um carvão betuminoso em suspensões aquosas. Foram realizadas medidas de adsorção, ensaios de flotação em bancada e medidas reológicas. Os polímeros aniônicos utilizados nos experimentos foram o ácido húmico, a carboximetil celulose e o sulfonato de poliestireno. As isotermas de adsorção mostraram uma baixa adsorção dos polímeros aniônicos na superfície do carvão, diminuindo a carga superficial para valores mais negativos. Essas cargas negativas tiveram efeito depressor sobre a hidrofobicidade natural do carvão. Os estudos sobre a reologia da polpa de carvão mostraram que a presença do ácido húmico no meio aumenta a molhabilidade do carvão, diminuído a tendência frequente de formação de agregados hidrofóbicos nas suspensões aquosas.

Santos (2006) estudou a possibilidade de utilização do ácido húmico como agente depressor da hematita, face às propriedades físico-químicas deste composto. Os ensaios de microflotação mostraram que na faixa de concentração entre 10 e 40 ppm de ácido húmico (depressor da hematita) e de 10 e 20 ppm de dodecilamina (coletor do quartzo) é possível separar o quartzo com recuperações superiores a $90 \%$ e com depressão de $60 \%$ da hematita. Os ensaios de flotabilidade mostraram que a faixa ideal de pH para a recuperação citada encontra-se entre 9,5 e 11,5. Esses resultados evidenciaram a potencialidade para uso do ácido húmico como agente depressor da hematita na flotação reversa de minérios de ferro.

\subsubsection{Amido}

O amido é um dos principais polissacarídeos utilizados como modificadores no processo de flotação, sendo utilizado em diversos sistemas como depressor de óxidos de ferro, ganga carbonática, argilo-minerais e hiperstênio. $O$ amido é constituído principalmente por moléculas de amilose (20 a 30\%) e de amilopectina 70 a $80 \%$ ), que são polímeros de glicose, e pode atingir um peso molecular de até $150.000 \mathrm{Da}$. Apesar da semelhante composição química, a amilose é um polímero linear e insolúvel, enquanto a amilopectina é um polímero ramificado e apresenta elevada solubilidade. Devido à presença de vários grupos $-\mathrm{OH}$ e do alto peso 
molecular da amilose e da amilopectina, essas moléculas são as principais responsáveis pela ação depressora do amido. As estruturas da amilose e da amilopectina são ilustradas na Figura 4.27 (NUNES; PERES, 2011).

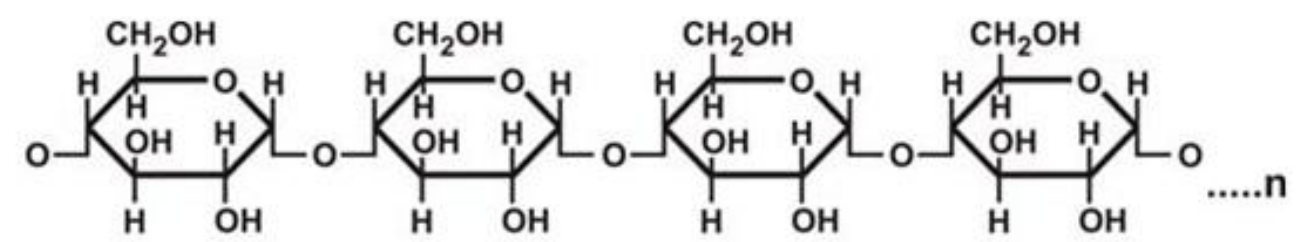

Amilose

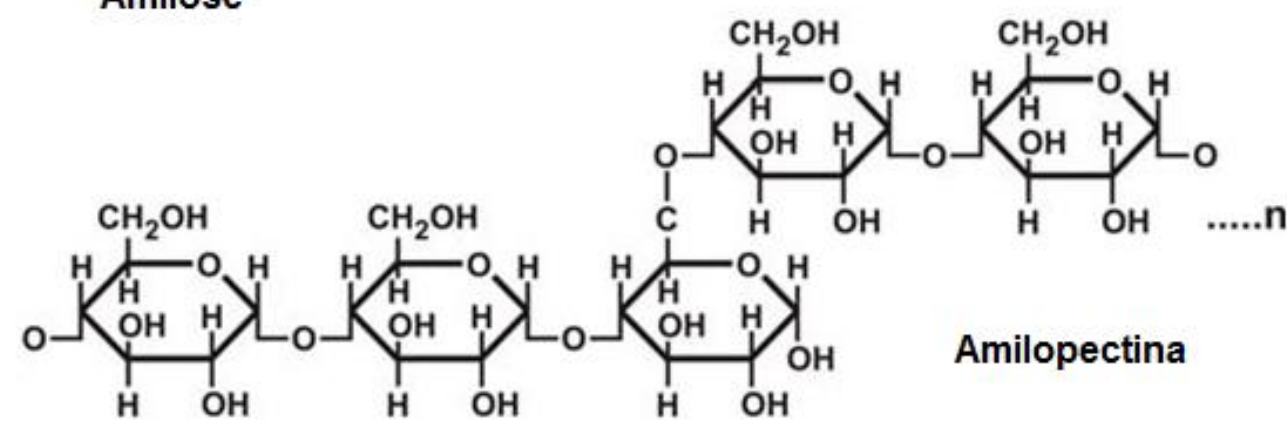

Figura 4.27 - Estruturas da amilose e da amilopectina

A amilopectina tem uma estrutura ramificada que pode diferir de acordo com a fonte do qual o amido é obtido. A proporção de amilose e amilopectina nunca é constante no amido e também não é responsável pelo efeito depressor. O que determina se o amido pode ser utilizado em processos de flotação são as várias modificações introduzidas durante o processo de fabricação, acidentalmente ou intencionalmente. Os grupos aldeídicos e alcoólicos na estrutura do amido são responsáveis por várias características específicas do mesmo (BULATOVIC, 2007).

O amido é um polímero insolúvel em água fria devido ao alinhamento em paralelo de suas cadeias carbônicas que se interagem via ligação de pontes de hidrogênio. O aquecimento e a caustificação são necessários para decompor e solubilizar o amido, que para ser utilizado como depressor, deve ser aquecido, gelatinizado ou oxidado e posteriormente reprecipitado. O amido é um polímero nãoiônico com ligeiras características aniônicas. Alguns estudos têm sido propostos no sentido de que a presença de traços de grupos fosfato presentes no amido de batata são os responsáveis pela sua afinidade e depressão da hematita. As principais fontes de amido são a batata, a mandioca, o milho e o arroz (PEARSE, 2005).

A Figura 4.28 ilustra um exemplo típico do efeito do amido como depressor. Verifica-se que diferentes tipos de amidos podem exibir diferentes ações 
depressoras. Neste estudo realizado por Bulatovic (1999), foram utilizados para depressão da galena, o amido pérola, o amido de milho e um amido tratado com ácido (stazine T.J.). Os amidos pérola e de milho tiveram pouco efeito na depressão de galena contida em um concentrado de cobre.

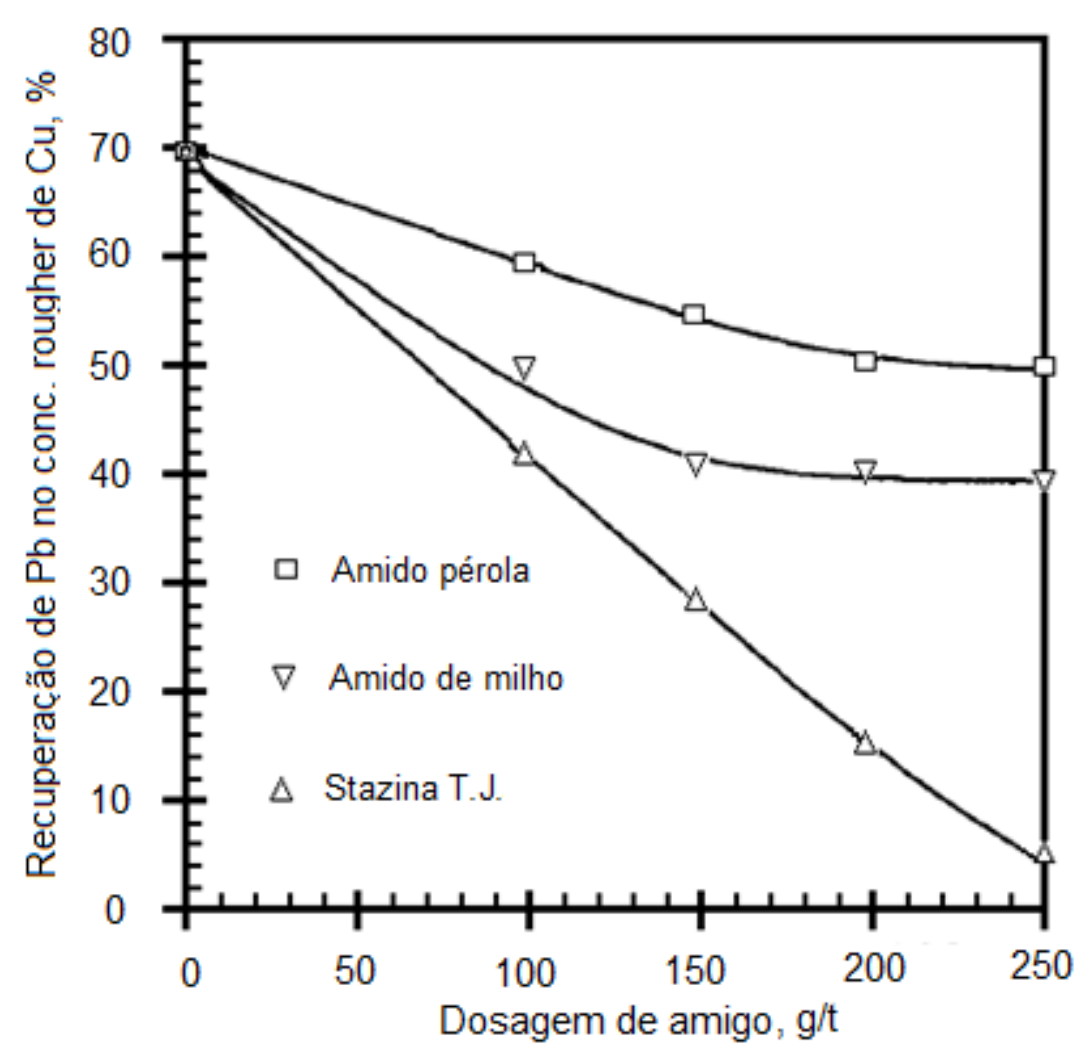

Figura 4.28 - Efeito do tipo de amido na recuperação de chumbo em concentrados rougher de cobre (adaptado de BULATOVIC; 1999)

No Brasil, a rota de flotação reversa do minério de ferro é a mais utilizada para recuperação de ferro em minérios itabiríticos. Neste processo, os minerais de ferro são deprimidos por amidos não modificados. Os amidos de milho são os mais utilizados como depressor da hematita e como têm um elevado peso molecular, precisam ser solubilizados com água quente e hidróxido de sódio antes do seu uso final (ARAÚJO et al., 2006; PERES e ARAÚJO, 2006).

Entre os reagentes depressores utilizados em plantas de flotação no Brasil, o amido desempenha um papel relevante como: (i) depressor da hematita na flotação catiônica reversa de óxidos de ferro em minérios itabiríticos; (ii) depressor da ganga carbonatada e de minerais portadores de ferro na flotação aniônica direta de rochas fosfáticas; (iii) depressor de ganga (minerais de argila) na flotação de minério de silvinita na produção direta de concentrados de KCl (PERES; CORREA, 1996). 


\subsubsection{Quebracho}

Quebracho vem da expressão quiebra-hacha devido à alta dureza da madeira das arvores de onde são obtidos. Os extratos de quebracho são uma combinação complexa de polifenóis obtidos por extração aquosa do cerne da árvore de Quebracho Colorado que cresce na América do Sul, na região do Chaco (nordeste da Argentina e sul do Paraguai). Esses polifenóis (Figura 4.29) são compostos naturais à base de taninos condensados com uma ampla gama de pesos moleculares (variando de 200 a 15.000 Da) que podem ser fracionados ou processados quimicamente de acordo com 0 uso final desejado. Outras características importantes dos quebrachos são a baixa concentração de açúcares e ácidos, a resistência à hidrólise e à ação de micro-organismos e a solubilidade em água em pH superior a 8 (PEARSE, 2005; UNITAN, 2012).

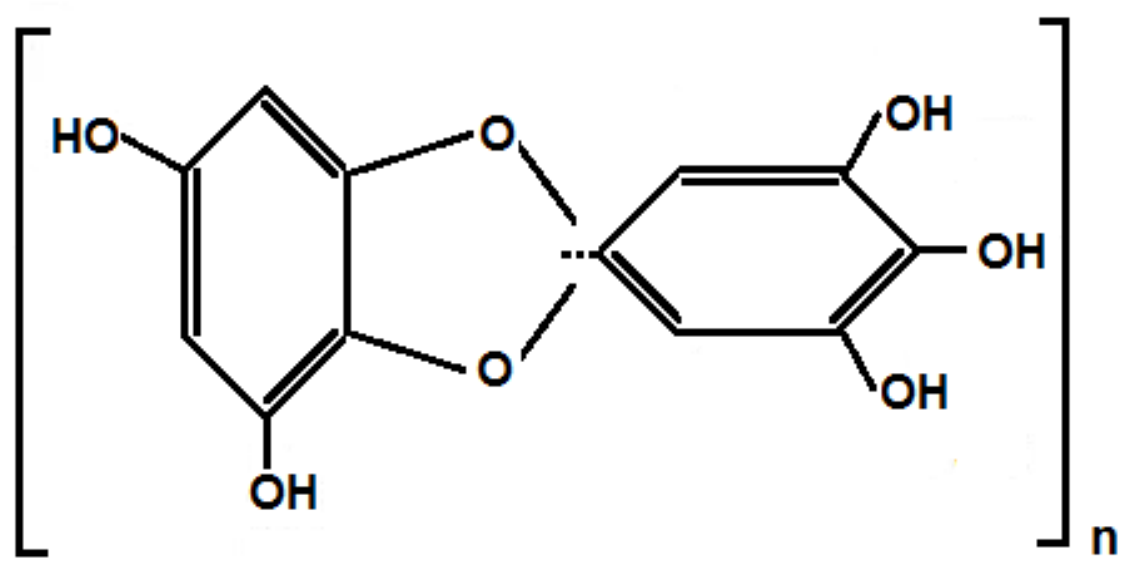

Figura 4.29 - Estrutura aproximada do quebracho, n=1-200 (PEARSE, 2005)

O quebracho é comercialmente disponível nas seguintes formas: Quebracho padrão (Qu-O), extraído diretamente do cerne da madeira com água quente e com $\mathrm{pH}$ ajustado; Quebracho sulfetado (Qu-S), com introdução do ácido sulfônico e Quebracho aminado (Qu-A), com introdução de um grupo amina no produto padrão, tornando-o um polímero anfotérico com ponto isoelétrico em $\mathrm{pH}$ 7. Cada um destes tipos de quebrachos tem uma aplicação e um efeito depressor diferente (BULATOVIC, 1999).

As moléculas polifuncionais dos extratos de quebracho têm um potencial considerável para adsorção na superfície de minerais, devido à presença de quantidade significativa de trímeros e tetrâmeros de polímeros C15 com grande número de grupos hidroxila $(-\mathrm{OH})$ nos núcleos fenólicos que o formam. A adsorção é resultante da união do hidrogênio com átomos superficiais, como, o oxigênio, o 
enxofre e o flúor; pela formação de complexos entre o grupo hidroxila com cátions di e trivalentes como o cálcio, bário, cobre, chumbo, zinco, ferro, alumínio, etc; pela neutralização de cargas em meio alcalino sobre a superfície carregada positivamente; ou pela atração eletrostática entre as micelas de taninos carregadas negativamente e a superfície mineral com carga positiva (CIRIBENI; SARQUIS: GONZÁLES, 2002).

Fuerstenau (1982) considerou três possibilidades para a adsorção do quebracho na superfície da calcita: atração eletrostática na superfície com excesso de carga positiva; ligações de hidrogênio e formação de um sal (tanato de cálcio) na superfície da calcita (BALTAR, 2010).

Castro e Hoces (1993) pesquisaram a ação depressora do quebracho sobre minerais salinos como a celestita $\left(\mathrm{SrSO}_{4}\right)$ e a calcita $\left(\mathrm{CaCO}_{3}\right)$, usando oleato de sódio como coletor. Os resultados obtidos indicaram que a adsorção do quebracho na calcita é mais efetiva que na celestita, embora em concentrações superiores a $0,12 \mathrm{~g} / \mathrm{L}$, o quebracho deprime completamente ambos os minerais na faixa de $\mathrm{pH}$ entre 7 e 10.

Sarquis et al. (2008) realizaram um estudo sobre o uso de extrato de quebracho modificado na separação cobre/molibdênio em substituição aos tradicionais métodos que utilizam o NaHS, reagente tóxico e de alto consumo. Neste estudo foi utilizado um concentrado com $93 \%$ Cu e $7 \%$ Mo produzido pela indústria mineral. No procedimento adotado, o concentrado mineral era condicionado com ácido sulfúrico em pH 4,5 para remoção da oxidação superficial das mesmas. Em seguida era recondicionada com quebracho modificado (Floatan T5, Unitan) e os minerais de cobre eram flotados com amil xantato de potássio. Neste trabalho foram recuperados $96 \% \mathrm{Cu}$ e $83 \%$ Mo. O consumo de Floatan T5 foi de $300 \mathrm{~g} / \mathrm{t}$ concentrado $\mathrm{Cu}$.

\subsubsection{Silicato de sódio}

O silicato de sódio é um sal inorgânico e um dos reagentes modificadores mais versáteis da indústria mineral. Devido a propriedades como estabilidade química, viscosidade, capacidade de polimerização, modificação de cargas superficiais é utilizado como um agente depressor, modificador ou até mesmo, como regulador de $\mathrm{pH}$, devido à sua característica alcalina (SILVA, 2011). É um dos 
depressores e/ou dispersante mais barato utilizado no processamento mineral e normalmente é adicionado na etapa de moagem.

A produção de silicato de sódio é feita pela fusão alcalina da barrilha (carbonato de sódio) com uma areia quartzosa. A proporção final $\mathrm{Na}_{2} \mathrm{O} / \mathrm{SiO}_{2}$ é dependente da relação estequiométrica utilizada na preparação inicial. Existem produtos de silicato de sódio no mercado com relações $\left(\mathrm{Na}_{2} \mathrm{O} / \mathrm{SiO}_{2}\right)$ de 1,60; 2,75; 3,22 e 3,75 (FUERSTERNAU; SOMASUNDARAN, 2003).

A maior utilização do silicato de sódio é como depressor de silicatos em processos onde os ácidos graxos de cadeia longa (C12 a $\mathrm{C} 18$ ) atuam como coletores, mas esse mecanismo de adsorção ainda não é muito bem compreendido. Acredita-se que as micelas do ácido silícico hidratado são as responsáveis pelo efeito depressor (BULATOVIC, 2007). O mecanismo de adsorção é feito segundo a reação de dissociação do silicato de sódio em água, Equação 4.6.

$$
\mathrm{Na}_{2} \mathrm{SiO}_{3}+2 \mathrm{H}_{2} \mathrm{O} \Leftrightarrow \mathrm{H}_{2} \mathrm{SiO}_{3}+2 \mathrm{Na}^{+}+2 \mathrm{OH}^{-} \quad \text { Equação } 4.6
$$

A máxima eficiência do silicato de sódio como depressor de ganga silicatada foi observada em polpas com pH entre 7 e 10 (FUERSTERNAU; SOMASUNDARAN, 2003 apud BALTAR, 2010).

Para ocorrer o efeito depressor/dispersor é necessário que ocorram reações de dissociação e polimerização do silicato de sódio, as quais são dependentes de fatores como $\mathrm{pH}$, temperatura e relação $\mathrm{Na}_{2} \mathrm{O} / \mathrm{SiO}_{2}$. As principais espécies dissociadas (ionizadas) são a sílica polimérica, monomérica e coloidal.

Os principais responsáveis pela depressão/dispersão dos silicatos e minerais oxidados são a sílica coloidal e o ânion silicato. Caso a sílica coloidal seja a responsável pelo efeito depressor, o mecanismo de adsorção seria a atração eletrostática. No caso do ânion silicato ser a espécie adsorvida, o mecanismo seria a quimissorção (LOPES, 2011). 


\section{METODOLOGIA}

A metodologia aplicada para o desenvolvimento da CARACTERIZAÇÃO E BENEFICIAMENTO DA MOLIBDENITA DA REGIÃO DE CAMPO FORMOSO - BA foi contemplada em três partes interdependentes e contíguas.

A parte inicial do trabalho teve por objetivo realizar caracterização tecnológica de minérios, concentrados, rejeitos e do processo utilizado pelos pequenos mineradores na recuperação da molibdenita produzida na Serra de Carnaíba, BA. Para tal, foram coletadas amostras de minérios, concentrados e rejeitos do processo de beneficiamento utilizado no local. Como resultados foram detectados entraves tecnológicos relacionados à produção de concentrado de molibdenita de baixo teor, resultando em um produto de pequeno valor agregado, devido à presença de outros minerais com propriedades físico-químicas semelhantes a da molibdenita.

A segunda parte teve por objetivo a realização de um estudo fundamental sobre a separação molibdenita/talco por flotação, com a utilização dos diferentes depressores empregados no beneficiamento mineral.

A terceira parte é a sugestão da aplicação dos resultados obtidos no estudo fundamental na purificação do concentrado de molibdenita atualmente produzido em Campo Formoso, de forma a agregar valor econômico ao mesmo.

\subsection{PROCEDIMENTO EXPERIMENTAL I - CARACTERIZAÇÃO TECNOLÓGICA DE MINÉRIOS, CONCENTRADOS, REJEITOS E DO PROCESSO UTILIZADO NA SERRA DE CARNAÍBA}

\subsubsection{Obtenção e preparação das amostras}

Para a realização deste estudo foram coletadas amostras de minérios $(50 \mathrm{~kg})$, rejeitos (30 kg) e concentrados $(5 \mathrm{~kg})$ produzidos na região da Serra de Carnaíba (Campo Formoso e Pindobaçu), BA. Foram coletadas três amostras de minério, três amostras de rejeito de flotação e três amostras de concentrados de molibdenita em pequenos produtores artesanais daquela região. $\mathrm{O}$ tipo de amostra e o local onde foram coletadas são apresentados na Tabela 5.1. 
Tabela 5.1 - Tipo de amostra e local de coleta

\begin{tabular}{ccc}
\hline Amostra & Origem & Localização \\
\hline Minério & Garimpo do Paulo (GP) & Carnaíba de Cima \\
Minério & Garimpo do Marota (GM) & Carnaíba de Baixo \\
Minério & Garimpo do Fernando (GF) & Carnaíba de Cima \\
Rejeito & ALL Minérios (ALL) & Carnaíba de Baixo \\
Rejeito & Garimpo do Sérgio (SE) & Carnaíba de Baixo \\
Rejeito & Garimpo do Tio Zé (TZ) & Carnaíba de Cima \\
Concentrado 3X & ALL Minérios & Carnaíba de Cima \\
Concentrado MM & ALL Minérios & Carnaíba de Baixo \\
Concentrado ITA & ALL Minérios & Carnaíba de Baixo \\
\hline
\end{tabular}

As amostras de minérios coletadas foram cominuídas em britador de mandíbulas e, em seguida, em moinho de martelos com crivo de abertura de $2 \mathrm{~mm}$, operando em circuito fechado com uma peneira de 1,65 mm. No estágio seguinte, realizou-se a homogeneização do material em pilha prismática alongada e desta foram retiradas alíquotas de $1 \mathrm{~kg}$ para os estudos de caracterização mineralógica e química, determinação do $\mathrm{Wl}$ e estudos de beneficiamento. O diagrama de blocos da Figura 5.1 ilustra o processo de preparação das amostras.

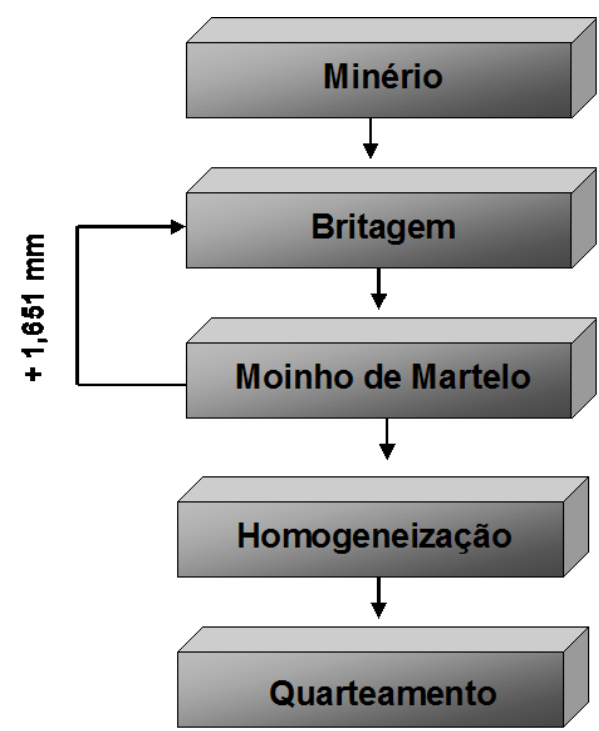

Figura 5.1 - Diagrama em blocos do processo de preparação das amostras

Alíquotas de $1 \mathrm{~kg}$ representativas das amostras de minérios denominadas GP, GM e GF, 100\% passantes em peneira de 1,65 mm, foram quarteadas em alíquotas menores de $100 \mathrm{~g}$ cada e enviadas para análise química e mineralógica por difração de raios-X. 
O minério foi classificado a seco em peneiras com aberturas de 600,425 , 300, 212, 150, 105 e $74 \mu \mathrm{m}$, em Ro-Tap, por 20 minutos, seguido de lavagem em peneirador, por mais $10 \mathrm{~min}$. De cada fração foi coletada uma amostra para análise química e o restante separado em líquido denso, no caso bromofórmio (densidade 2,89). De cada produto afundado e flutuado separou-se alíquota para análise química e para cálculo de liberação. De uma das alíquotas, aquela da qual se dispunha de maior massa, também foram confeccionadas secções polidas dos produtos afundado e flutuado, para análise ao microscópio eletrônico de varredura (MEV), equipado com sistema de microanálise por dispersão de energia EDS. As amostras do minério foram analisadas por espectroscopia por fluorescência de raios$X(F R X)$ e difratometria de raios-X (DRX) para esclarecer dúvidas com relação à mineralogia da amostra.

\subsubsection{Caracterização mineralógica e química}

A caracterização mineralógica e química foi realizada nos laboratórios do CETEM, por meio das técnicas de espectrometria de fluorescência de raios- $X$ (FRX) para análise química, difratometria de raios-X (DRX) para a mineralogia, análise de imagem com auxílio de lupa binocular, microscopia eletrônica de varredura (MEV) e análise termodiferencial e termogravimétrica - ATD/TG.

\subsubsection{Difratometria de raios- $X$}

As análises por DRX, pelo método do pó total prensado, foram executadas em um equipamento Bruker-AXS D4 Endeavour, nas seguintes condições de operação: radiação Co $\mathrm{K} \alpha(35 \mathrm{kV} / 40 \mathrm{~mA})$, velocidade do goniômetro de $0,02^{\circ} 2 \theta$ por passo com tempo de contagem de 1,0 segundo por passo e coletados de 5 a 80 $2 \theta$. A interpretação qualitativa de espectro foi efetuada por comparação com padrões contidos no banco de dados PDF2 (ICDD, 2006) em software Bruker Diffrac ${ }^{\text {Plus. }}$.

\subsubsection{Microscopia eletrônica de varredura}

As análises ao MEV foram efetuadas num equipamento LEO S440, equipado com detector de elétrons retro-espalhados, gerando imagens onde os níveis de cinza são proporcionais ao peso atômico médio do material analisado; quanto maior o seu peso atômico, mais claras as fases aparecem na imagem. Análises químicas pontuais puderam ser obtidas pelo acoplamento a um espectrômetro de dispersão 
de energia de raios-X (EDS), Oxford Link L300 e detector de SiLi Pentfet e janela ultrafina ATW2, com resolução de 128 eV a 5,9 keV.

\subsubsection{Análises químicas}

As análises químicas das amostras foram obtidas por espectrometria de fluorescência de raios-X (FRX) e/ou gravimetria, após abertura fortemente oxidante em ácidos, utilizando-se ácido perclórico.

Nas amostras de rejeitos de flotação, além da análise química, também foram realizadas análises granulométricas, de forma a verificar se $0 \mathrm{~d}_{80}$ do processo de moagem empregado encontrava-se em consonância com os resultados obtidos sobre o grau de liberação do mineral de interesse (molibdenita), em relação aos minerais de ganga.

\subsubsection{Análise térmica - ATD/TG}

Os estudos termoanalíticos (análise termodiferencial e termogravimétrica ATD/TG) utilizados para caracterização do concentrado de molibdenita foram realizados em um analisador TA Instruments, modelo 2960 SDT V3.0F. Os parâmetros utilizados foram razão de aquecimento $10^{\circ} \mathrm{C} / \mathrm{min}$, faixa de temperaturas de 25 a $1200^{\circ} \mathrm{C}$, atmosfera com ar super-seco na vazão de $10 \mathrm{~mL} / \mathrm{min}$ e alumina (coríndon) como substância padrão.

A ATD e a TG tiveram por objetivo interpretar as transformações físicas ou químicas e variações térmicas no concentrado de molibdenita.

\subsubsection{Determinação experimental do "work index" de Bond (WI)}

Os ensaios para determinação do Work Index (WI) foram realizados em um moinho padrão (Bond) de acordo com a metodologia descrita na norma técnica NBR 11376 ABNT, que permite o cálculo do índice de moabilidade (Mob), equivalente em gramas passante na peneira de malha teste, gerada em cada rotação do moinho, simulando um circuito fechado (BARBATO; SAMPAIO, 2007).

\subsubsection{Ensaios de beneficiamento em escala de bancada}

\subsubsection{Britagem e Moagem}

Os minerais-minério devem estar liberados para responderem com eficiência, aos processos de beneficiamento por flotação. 
Inicialmente foram realizados ensaios de moagem em moinhos de jarro, por batelada, com o objetivo de se determinar qual seria o tempo necessário para a cominuição da amostra dos minérios, até $90 \%$ menor que a granulometria onde a molibdenita (mineral de interesse) encontra-se liberada dos minerais de ganga (para todos os minérios) e possível de concentração por flotação. Esses ensaios de moagem foram conduzidos a úmido em moinho de barras de laboratório (300 mm x $165 \mathrm{~mm}$ ), tendo como meio moedor 10 barras de diâmetro de $20 \mathrm{~mm}$. Os testes de moagem foram realizados com amostras de $1 \mathrm{~kg}$ e a percentagem de sólidos em peso de 50\% (BRAGA, 1999).

\subsubsection{Flotação}

Os estudos preliminares de flotação foram realizados em uma célula DENVER Mod D12 de laboratório, com uma cuba de $3 \mathrm{~L}$ e amostras de $1 \mathrm{~kg}$.

Inicialmente o minério com granulometria menor que $3 \mathrm{~mm}$ era reduzido em moinhos de barras, conforme os resultados fornecidos pelas curvas de moagem. $O$ óleo de pinho foi utilizado como espumante e reforçador de hidrofobicidade.

A flotação da molibdenita foi realizada em duas etapas (rougher e cleaner). A etapa rougher tem a função de promover a primeira separação entre a molibdenita e os minerais contaminantes; a etapa cleaner é o estágio de limpeza do concentrado da flotação, com o objetivo de aumentar o teor de molibdenita no concentrado final. $\mathrm{Na}$ Tabela 5.2 constam as condições operacionais desses ensaios de flotação.

Tabela 5.2 - Condições operacionais do processo de flotação em bancada

\begin{tabular}{lcc}
\hline & Etapa rougher & Etapa cleaner \\
\hline $\mathrm{pH}$ & $7-8,5$ & $7-8,5$ \\
Tempo de condicionamento com óleo de pinho & $2 \mathrm{~min}$ & $2 \mathrm{~min}$ \\
Concentração do óleo de pinho & $150 \mathrm{~g} / \mathrm{t}$ & $75 \mathrm{~g} / \mathrm{t}$ \\
$\%$ de sólidos no condicionamento & 37 & 20 \\
$\%$ de sólidos na flotação & $30-15$ & 20 \\
Tempo de flotação & $2 \mathrm{~min}$ & $1 \mathrm{~min}$ \\
\hline
\end{tabular}

Os ensaios preliminares realizados com os minérios GP, GM e GF (Tabela 5.1) permitiram a elaboração de uma rota preliminar de beneficiamento para a recuperação da molibdenita de Campo Formoso. Genericamente, o beneficiamento desses minérios foi constituído das seguintes etapas: britagem, moagem, e flotação rougher e cleaner. 


\subsection{PROCEDIMENTO EXPERIMENTAL II - ESTUDOS FUNDAMENTAIS DE SEPARABILIDADE DO SISTEMA MOLIBDENITA/TALCO}

Para desenvolvimento da parte experimental desta seção, "Estudos Fundamentais de Separação por Flotação do Sistema Molibdenita/Talco" e tomando como base as informações contidas na bibliografia consultada, foram coletadas amostras de concentrados de molibdenita e talco e selecionados alguns reagentes modificadores (depressores).

\subsubsection{Obtenção e preparação das amostras}

O concentrado de molibdenita foi fornecido por pequenos mineradores de esmeralda da Serra de Carnaíba, BA. O concentrado de talco (macrocristalino), com aspecto untoso e partículas lamelares, foi fornecido pela Mineração Paranaense de Ponta Grossa, PR.

\subsubsection{Caracterização mineralógica e química}

A caracterização foi realizada com as mesmas técnicas descritas anteriormente no item 5.1.2, além de outras técnicas como: distribuição do tamanho de partícula em granulômetro a laser e determinação da quantidade de material insolúvel em ácido clorídrico, segundo o procedimento descrito por Huch e Valles (1975).

\subsubsection{Distribuição do tamanho de partículas}

As distribuições do tamanho de partículas das amostras de molibdenita e talco foram determinadas no granulômetro a laser Master Size da Malvern Instruments.

A amostra de talco foi britada e cominuída em gral de porcelana, até uma granulometria inferior a $150 \mu \mathrm{m}$. A amostra de molibdenita já se encontrava em uma granulometria inferior a $150 \mu \mathrm{m}$. Para se obter melhor dispersão, as amostras foram submetidas a tratamento com ultrassom, por um período de 5 minutos.

\subsubsection{Análise química}

As análises químicas das amostras foram obtidas por fluorescência de raios$X$, gravimetria e espectroscopia de absorção atômica com chama, após solubilização em ácidos. Foram realizadas análises químicas para as amostras de molibdenita e 
talco. Também foi determinada a quantidade de material insolúvel em ácido clorídrico.

\subsubsection{Reagentes}

Após a revisão da literatura foram selecionados os seguintes depressores para os estudos de flotabilidade: goma guar, dextrina, carboximetil celulose (CMC), ácido húmico, amido, quebracho e silicato de sódio.

Utilizou-se o metil isobutil carbinol (MIBC) como espumante, adicionado em solução aquosa de 100 ppm e hidróxido de potássio e ácido clorídrico (grau analítico) como reguladores de $\mathrm{pH}$. O cloreto de potássio foi adicionado em solução aquosa de $10^{-3}$ moles/L para manter a força iônica durante os ensaios de flotação. $A$ Tabela 5.3 sumariza os reagentes utilizados e suas funções.

Tabela 5.3 - Reagentes utilizados no processo e suas funções

\begin{tabular}{ccc}
\hline Reagente & Fornecedor & Função \\
\hline Goma guar & Sigma-Aldrich & Depressor \\
Dextrina & Vetec & Depressor \\
CMC (Denvercel MN) & Denver & Depressor \\
Ácido húmico & Sigma-Aldrich & Depressor \\
Amido (Amidex $\left.{ }^{\circledR} 3001\right)$ & Corn Products & Depressor \\
Quebracho (Floatam T5) & Unitan Saica & Depressor \\
Silicato de sódio $\left(20-30 \% \mathrm{Na}_{2} \mathrm{O}\right)$ & Vetec & Depressor \\
MIBC & Rhodia & Espumante \\
Hidróxido de potássio & Vetec & Regulador de pH \\
Ácido clorídrico & Vetec & Regulador de pH \\
Cloreto de potássio & Vetec & Mantenedor de força iônica \\
\hline
\end{tabular}

\subsubsection{Ensaios de flotabilidade}

Os ensaios de flotabilidade foram realizados em uma célula Partrigde \& Smith (Figura 5.2), de acordo com os procedimentos dos trabalhos de Ozkan e Yekeler (2003) e Jara e Castro (2006). 


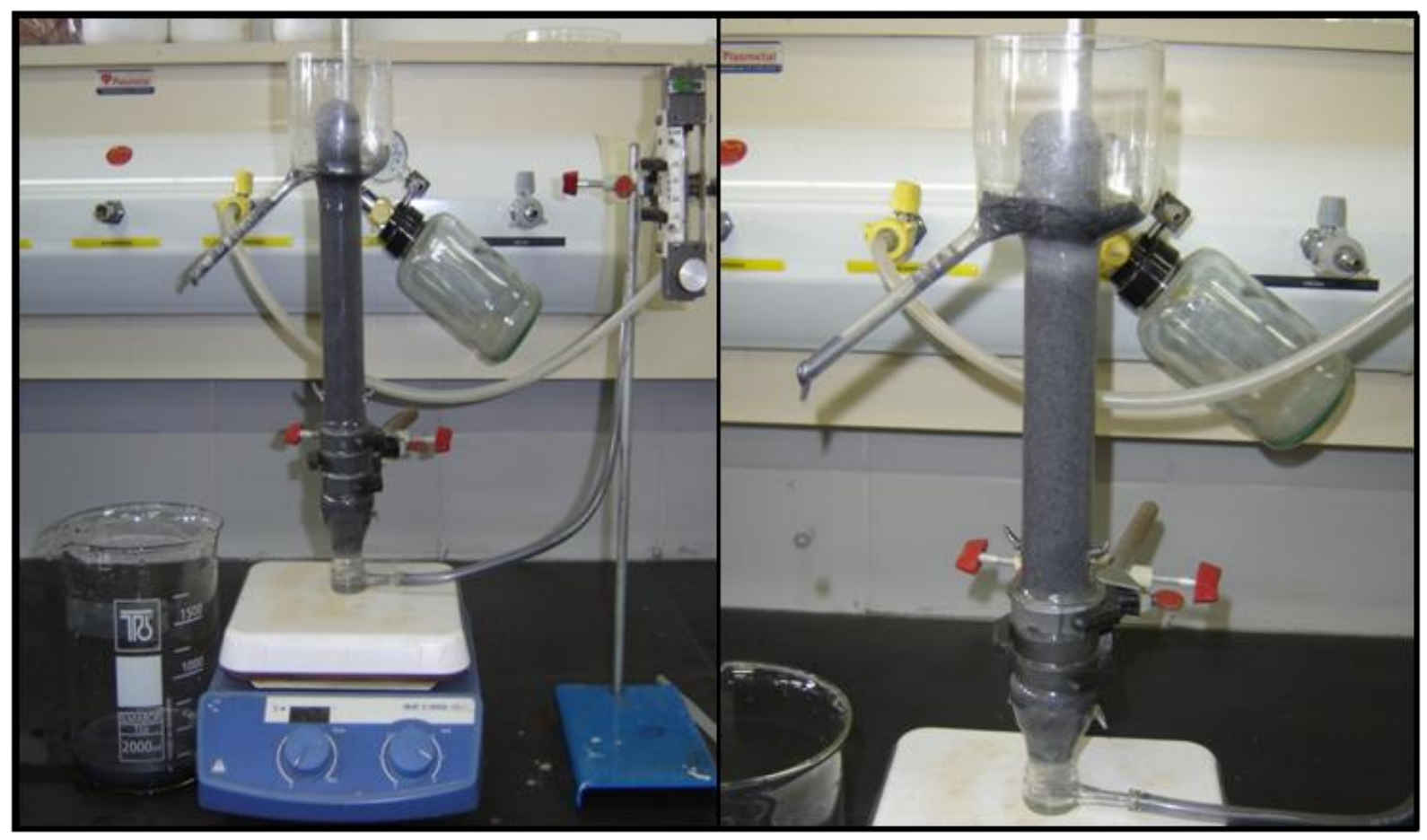

Figura 5.2 - Sistema de flotação com célula Partridge \& Smith

Os ensaios de flotabilidade tiveram por objetivo verificar a influência dos depressores selecionados na flotabilidade dos minerais molibdenita e talco. Também foram realizados ensaios para verificar a cinética de flotação desses minerais na ausência desses modificadores de superfície (depressores).

Para realização dos ensaios de flotabilidade, as amostras dos concentrados de molibdenita e talco foram peneiradas e classificadas nas frações: $-150+74 \mu \mathrm{m}$; $-74+37 \mu \mathrm{m}$ e $-37 \mu \mathrm{m}$.

\subsubsection{Procedimento dos ensaios de flotação}

$\mathrm{O}$ pH da suspensão mineral, preparada com $3 \mathrm{~g}$ de amostra, era ajustado em um béquer sob agitação magnética. Em seguida essa suspensão era condicionada por $5 \mathrm{~min}$, com o reagente depressor e depois com o espumante (MIBC) por mais 5 $\min$.

Após o condicionamento, a suspensão era flotada na célula Partridge \& Smith com $250 \mathrm{~mL}$ de capacidade, durante 3 min. Para geração das bolhas utilizou-se ar filtrado pressurizado que era introduzido na célula por uma placa porosa na vazão de $1 \mathrm{~L} / \mathrm{min}$.

Os ensaios de flotação foram realizados nos pH's 2, 4, 6, 8, 10 e 12 e a concentração dos depressores foi fixada em 100 ppm. Ensaios adicionais foram 
realizados para verificar a influência da concentração do depressor na flotabilidade do talco e da molibdenita.

Ao final dos ensaios de flotação, os produtos afundados e flotados eram secos e pesados para avaliação da flotabilidade (relação mássica entre o produto flotado e a soma dos produtos flotado e afundado), segundo a Equação 5.1.

$$
\text { Flotabilidade }(\%)=100 \cdot \frac{\text { massa flotada }}{\text { massa flotada+massa afundada }} \quad \text { Equação } 5.1
$$

Todos os ensaios de flotação foram executados em triplicata e os resultados cujo desvio padrão foi maior do que $5 \%$ foram repetidos.

\subsubsection{Determinação do potencial zeta}

Com o objetivo de verificar a influência do $\mathrm{pH}$ sobre o potencial zeta da molibdenita e do talco, na presença e ausência de agentes depressores, foram realizadas medidas do potencial em um medidor Zetasizer Nano-ZS (Figura 5. 3).

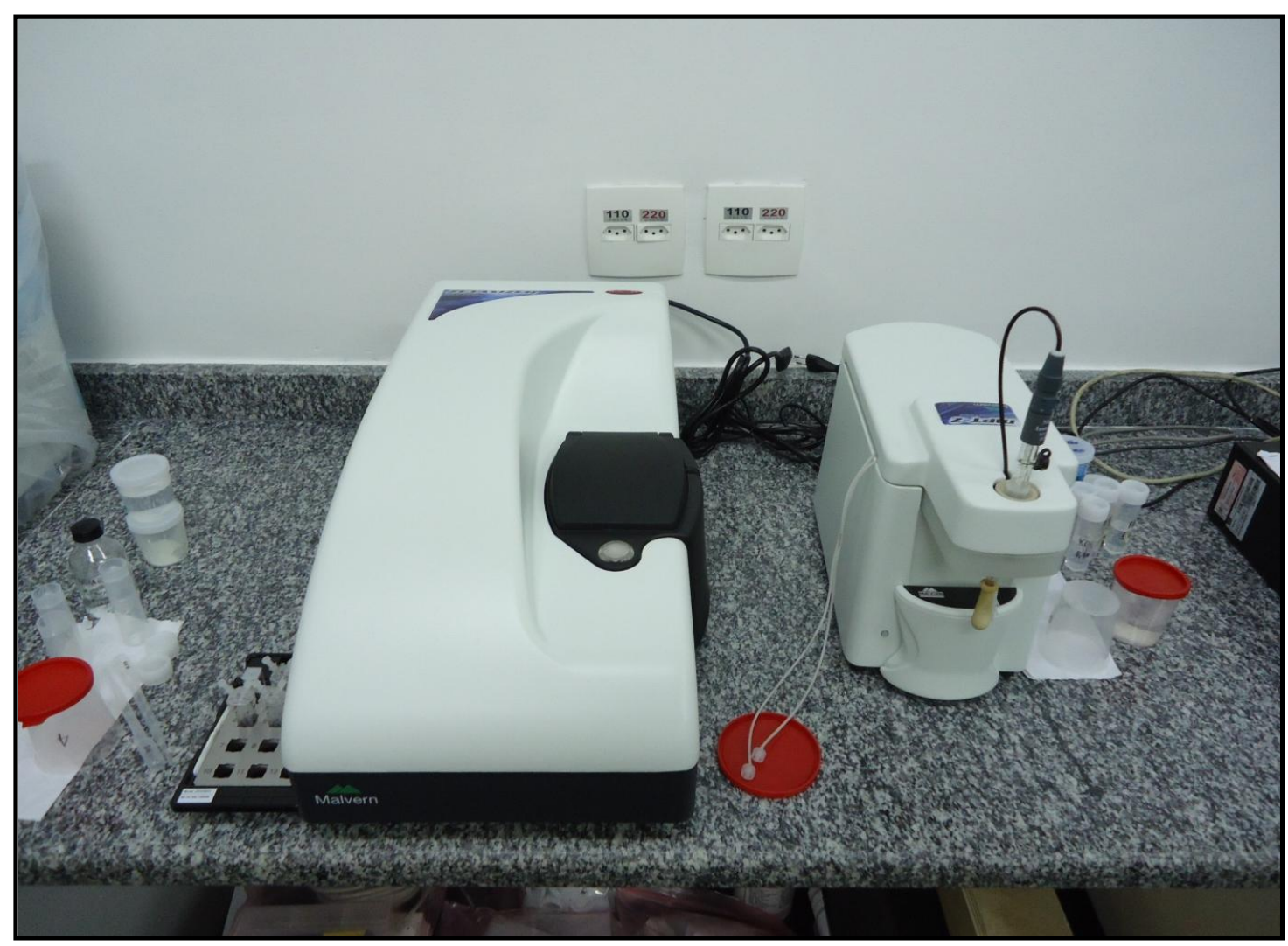

Figura 5.3 - Medidor Zetasizer Nano-ZS 
O potencial zeta é medido pela técnica de Laser Doppler Micro-eletroforese, onde um campo elétrico é aplicado a uma dispersão de partículas, que se movem a uma velocidade relativa ao seu potencial zeta. A partir desta velocidade, a mobilidade eletroforética e o potencial zeta são calculados. Este equipamento possui um titulador automático acoplado, que permite a determinação do potencial zeta em uma faixa ampla de $\mathrm{pH}$, sem a necessidade da troca de amostras (MALVERN, 2009).

\subsubsection{Medida do ângulo de contato pelo método de ascensão capilar}

As medidas do ângulo de contato pelo método de ascensão capilar foram realizadas no tensiômetro Krüss K100 (Figura 5.4). Os minerais ensaiados (molibdenita e talco) foram pesados e compactados em um tubo cilíndrico até altura de aproximadamente $20 \mathrm{~mm}$. O tubo do tensiômetro, com $50 \mathrm{~mm}$ de altura e $10 \mathrm{~mm}$ de diâmetro interno, tinha um filtro poroso na extremidade que permitia a percolação de líquidos e retenção dos minerais compactados. As medições foram realizadas usando um solvente apolar (n-hexano) e um solvente polar (água).

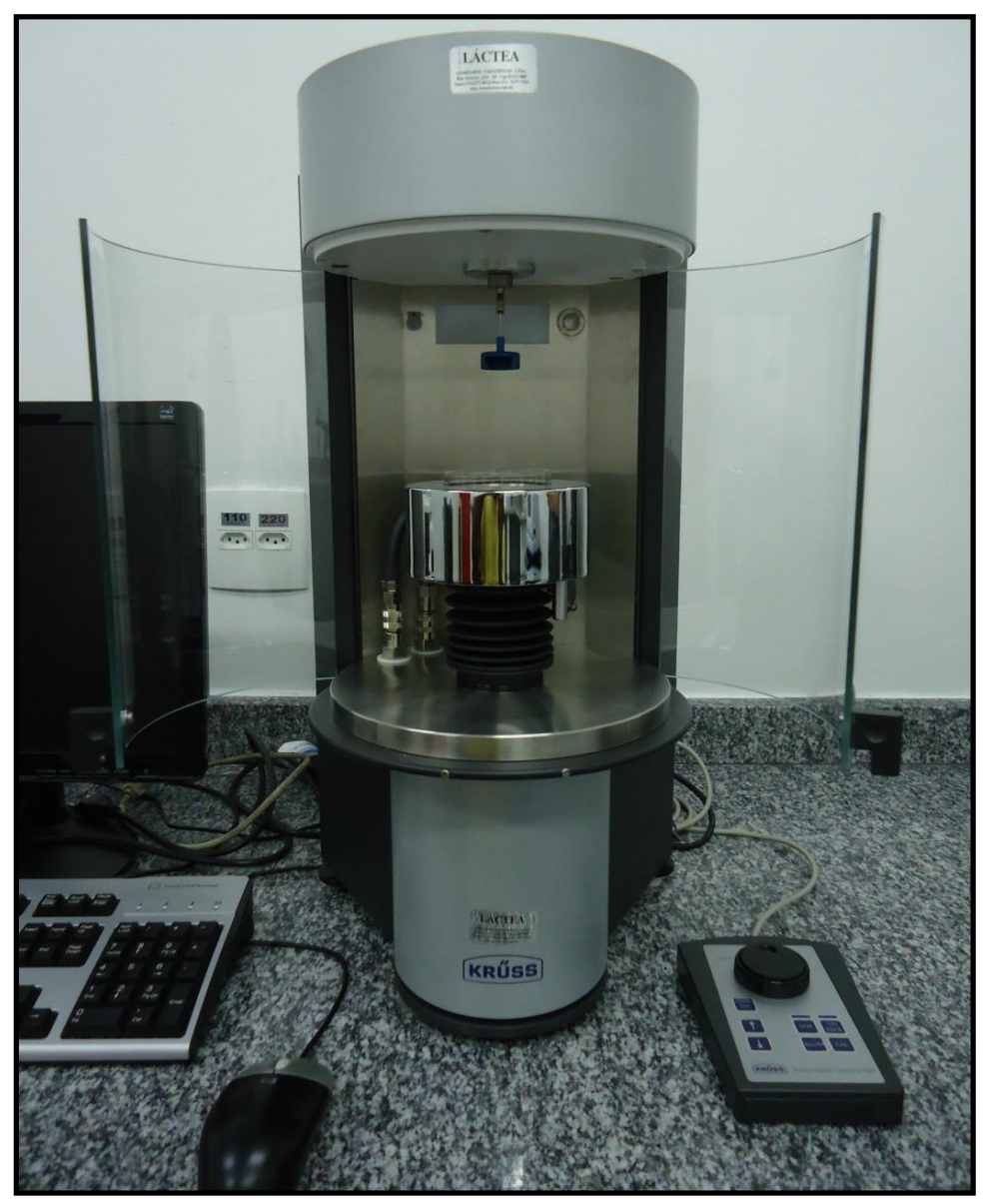

Figura 5.4 - Tensiômetro Krüss K100 
A partir da Equação de Washburn modificada ( $\mathrm{m}^{2}$ em função $\mathrm{t}$ ) (Equação 5.2) é possível determinar o ângulo de contato $(\theta)$ pelo método de ascensão capilar, por meio de medidas físicas, como o ganho de massa do líquido absorvido $(m)$ em função do tempo (t) (MARTINS, 2009; SIEBOLD et al.;1997).

$$
\frac{m^{2}}{t}=\frac{c \rho^{2} \gamma_{L G} \cos \theta}{\eta}
$$

Onde:

m - massa de líquido absorvido;

$\mathrm{t}$ - tempo gasto para a absorção;

$\rho$ - peso específico do líquido;

$\gamma$ - tensão superficial do líquido;

$\eta$ - viscosidade do líquido;

$\theta$ - ângulo de contato de avanço;

c - constante.

A constante (c) é determinada segundo a Equação 5.3.

$$
c=\frac{1}{2} \pi^{2} r^{5} n^{2}
$$

Onde $n$ é o número de capilares e $r$ é o raio capilar médio formado pelos espaços vazios entre as partículas empacotadas.

No tensiômetro Krüss $\mathrm{K} 100$ as medidas do ângulo de contato eram automaticamente determinadas pelo software do equipamento, utilizando-se a equação de Washburn (MARTINS, 2009; VIEGAS e MONTE, 2012).

Foram realizadas medidas do ângulo de contato, pelo método de ascensão capilar, para os minerais puros (molibdenita e talco) e para os minerais tratados com depressores (dextrina e quebracho) em diferentes concentrações.

\subsubsection{Medida do peso molecular da dextrina e do quebracho}

A determinação do peso molecular dos depressores dextrina e quebracho foi realizada no equipamento Zetasizer Nano ZS utilizando a técnica Static Light Scattering ( $S L C$ ). Nesse procedimento foram preparadas quatro soluções em 
diferentes concentrações $(0,25 ; 0,5 ; 0,75$ e $1,0 \mathrm{~g} / \mathrm{L})$ do depressor que se desejava conhecer o seu peso molecular.

Antes de iniciar o procedimento, o equipamento foi calibrado com um solvente padrão para referência (líquido puro). O solvente utilizado foi água destilada.

Após a calibração, cada solução, da menor para a de maior concentração, foi colocada no aparelho. A técnica consistiu em submeter as soluções a feixes de radiação do tipo laser que se dispersavam quando em contato com as partículas da solução, sendo possível obter a intensidade desses feixes dispersados em função do tempo.

Esse processo é baseado na Equação 5.4 de Rayleigh:

$$
\frac{K C}{R_{\theta}}=\left(\frac{1}{M_{W}}+2 A_{2} C\right) P(\theta)
$$

Onde:

$R_{\theta}$ - Razão de Rayleigh (razão entre a quantidade de luz dispersa e luz incidente na amostra);

$M_{W}$ - Peso molecular da amostra, Da (Daltons);

$A_{2}$ - Segundo coeficiente virial;

$\mathrm{C}$ - Concentração $(\mathrm{g} / \mathrm{L})$;

$P_{\theta}$ - Dependência angular da intensidade de dispersão da amostra

$\mathrm{K}$ - Constante ótica, definida pela Equação 5.5 .

$$
K=\frac{4 \pi^{2}}{\lambda_{0}{ }^{4} N_{A}}\left(n_{0} \frac{d n}{d c}\right)^{2}
$$

Onde:

$N_{A}$ - Constante de Avogrado;

$\lambda_{0}$ - Comprimento de onda do laser;

$n_{0}$ - Índice de refração do solvente;

$d n / d c$ - Índice diferencial de refração. 
A representação gráfica que permite determinar o peso molecular é chamada de Debye Plot e é representada por três eixos: intensidade de luz dispersada, $\mathrm{KC} / \mathrm{R}_{\theta}=1 / M_{w}$; concentração das amostras ( $\mathrm{g} / \mathrm{L}$ ) e intensidade (kcps) (MALVERN, 2009). 


\subsection{PROCEDIMENTO EXPERIMENTAL III - PURIFICAÇÃO DO CONCENTRADO DE MOLIBDENITA EM BANCADA}

\subsubsection{Amostragem e caracterização}

O concentrado de molibdenita foi fornecido por pequenos mineradores de Carnaíba, BA e foi produzido pelo processo de flotação descrito no item 4.10.7. O talco é um mineral naturalmente hidrofóbico (não possui afinidade por água), assim como a molibdenita. Desta forma, no beneficiamento por flotação, o talco é flotado com a molibdenita, resultando numa diminuição do teor de $\mathrm{MoS}_{2}$ (molibdenita) no concentrado.

O concentrado de molibdenita utilizado nestes ensaios era de baixo teor $\left(75,1 \% \mathrm{MoS}_{2}\right)$ e consequentemente de baixo valor agregado. Este concentrado foi previamente tratado com hidróxido de potássio diluído ( $5 \mathrm{~g} / \mathrm{L}$ ), para retirada de impurezas e reagentes residuais, e foi utilizado em sua granulometria original, isto é, sem descarte de frações finas ou grosseiras. A análise química do concentrado de molibdenita e sua distribuição granulométrica estão apresentadas no item 6.3.

\subsubsection{Purificação da molibdenita por flotação}

Os procedimentos adotados nesta seção foram baseados nos resultados dos estudos fundamentais de microflotação realizados conforme metodologia apresentada no item 5.2, porém com modificações, principalmente no tipo de equipamento utilizado (célula de flotação Denver D12), quantidade de material ensaiado e dosagem dos reagentes em função do scale up.

Para a realização dos testes em bancada, a dextrina foi selecionada como reagente depressor, no processo de flotação reversa, pois apresentou uma boa interação com a molibdenita nos testes de microflotação.

Com base nos resultados obtidos nos ensaios de microflotação, cujo objetivo principal foi verificar a interação da molibdenita com reagentes depressores, foram realizados ensaios de purificação do concentrado de molibdenita, por flotação em bancada, em célula Denver Mod. D12, com cuba de $1000 \mathrm{~mL}$ de capacidade.

Nesta etapa, as dosagens dos reagentes foram calculadas em termos de gramas de reagente por tonelada de alimentação à flotação (concentrado de 
molibdenita). Foram realizados ajustes nas dosagens utilizadas nos ensaios de microflotação para adequação aos ensaios em bancada.

A flotação da molibdenita foi realizada em três etapas (rougher, cleaner $1 \mathrm{e}$ cleaner 2), conforme apresentado no diagrama da Figura 5.5. A etapa rougher foi o estágio inicial e teve a função de promover a primeira separação entre a molibdenita e os minerais contaminantes; as etapas cleaner 1 e cleaner 2 representaram 0 estágio de limpeza do concentrado da flotação (deprimido) e tiveram por objetivo aumentar o teor de molibdenita no concentrado final.

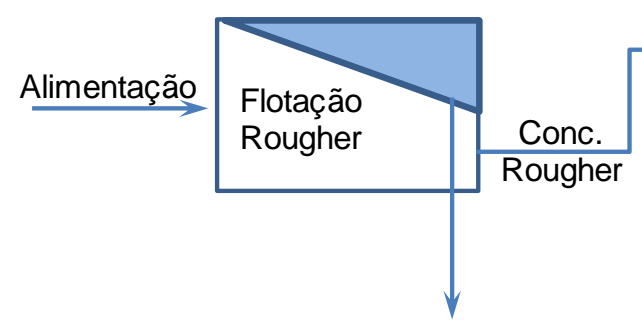

Rejeito Rougher

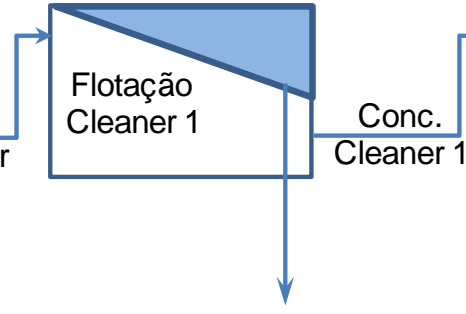

Rejeito Cleaner 1

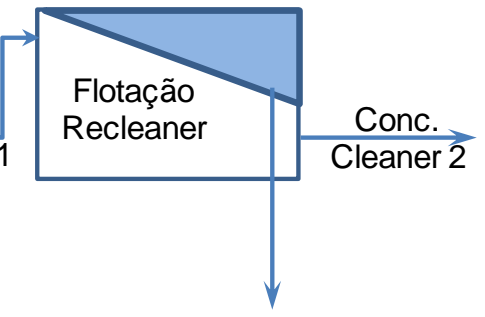

Rejeito

Cleaner 2

Figura 5.5 - Diagrama do processo de flotação em bancada

Foi utilizada a dextrina nas concentrações de 800, 400, 200 e 100 g/t como depressor da molibdenita, no processo de flotação reversa. O MIBC foi utilizado como agente espumante nas concentrações de $150 \mathrm{~g} / \mathrm{t}$ (rougher) e $75 \mathrm{~g} / \mathrm{t}$ (cleaner). A Tabela 5.4 mostra as condições operacionais utilizadas nos testes de flotação em bancada para purificação do concentrado de molibdenita. Os ensaios foram realizados com cerca de 300 gramas de concentrado de molibdenita na alimentação do estágio rougher.

Tabela 5.4 - Condições operacionais do processo de flotação em bancada

\begin{tabular}{cccc}
\hline & \multicolumn{3}{c}{ Etapas } \\
\cline { 2 - 4 } & Rougher & Cleaner 1 & Cleaner 2 \\
\hline pH & 8 & 8 & 8 \\
Concentração da dextrina $(\mathrm{g} / \mathrm{t})$ & $800 / 400 / 200 / 100$ & - & - \\
Concentração do MIBC $(\mathrm{g} / \mathrm{t})$ & 150 & 75 & 75 \\
Tempo de condicionamento $(\mathrm{min})$ & 6 & - & - \\
Tempo de flotação $(\min )$ & 6 & 3 & 3 \\
\% Sólidos $(\mathrm{p} / \mathrm{p})$ & 30 & & \\
\hline
\end{tabular}

No ensaio de flotação em bancada, onde foi utilizada a dosagem de dextrina de $100 \mathrm{~g} / \mathrm{t}$, foram realizadas 5 (cinco) etapas cleaner, seguindo práticas mundiais 
para enriquecimento do concentrado flotado de molibdenita. Nos demais ensaios foram realizadas 2 (duas) etapas cleaner.

\subsubsection{Purificação do concentrado de molibdenita por lixiviação fluorídrica}

A estrutura em camadas da molibdenita a torna um lubrificante muito eficiente e por ser de origem geotérmica, tem resistência para suportar calor e pressão. A molibdenita é inerte a muitos produtos químicos e preenche um espaço de uso industrial onde a grafita encontra limitações.

Com o objetivo de produzir um concentrado de molibdenita com alto teor $\left(>98 \% \mathrm{MoS}_{2}\right)$ e valor agregado para uso direto como agente lubrificante foram realizados ensaios exploratórios de lixiviação fluorídrica (para eliminar a sílica e os silicatos) com a molibdenita produzida em Campo Formoso, com 75,1\% de $\mathrm{MoS}_{2}$.

Os ensaios foram conduzidos em escala de bancada, em reator de polietileno sob agitação, na temperatura ambiente, utilizando-se como lixiviante o ácido fluorídrico (HF) diluído na concentração de 5\% (p/v) e relação sólido/líquido de $20 \%$. O tempo de lixiviação total foi de 4 (quatro) horas e amostras foram retiradas a cada 30 minutos com objetivo de acompanhar a cinética de dissolução dos contaminantes. Esses ensaios foram conduzidos com o concentrado de molibdenita na granulometria menor que $37 \mu \mathrm{m}$, pois o objetivo final era a obtenção de um produto grau lubrificante. 


\section{RESULTADOS E DISCUSSÃO}

6.1 CARACTERIZAÇÃO TECNOLÓGICA DE MINÉRIOS, CONCENTRADOS, REJEITOS E DO PROCESSO UTILIZADO NA SERRA DE CARNAÍBA

\subsubsection{Caracterização Química e Mineralógica}

\subsubsection{Amostras de Minério}

$\mathrm{Na}$ Tabela 6.1 podem ser observados os resultados da análise química do minério $R O M$ coletado na região de Campo Formoso e Pindobaçu. Verifica-se que os minérios apresentam teores diferenciados de molibdênio $(0,21 \%, 0,50 \%$, e 1,73\% $\mathrm{MoO}_{3}$ ). Também contêm teores elevados de $\mathrm{MgO}$ e de $\mathrm{Al}_{2} \mathrm{O}_{3}$, devido à presença de talco e clorita/clinocloro que são silicatos de magnésio e/ou alumínio hidratado, sempre presente nos xistos.

Tabela 6.1 - Análise química de minérios de Campo Formoso

\begin{tabular}{cccc}
\hline \multirow{2}{*}{ Componentes } & \multicolumn{3}{c}{ Teores (\%) } \\
\cline { 2 - 4 } & Amostra GP & Amostra GM & Amostra GF \\
\hline $\mathrm{MoS}_{2}$ & $\mathbf{0 , 2 3}$ & $\mathbf{0 , 6 3}$ & $\mathbf{1 , 9 2}$ \\
$\mathrm{SiO}_{2}$ & 50,52 & 43,59 & 45,83 \\
$\mathrm{TiO}_{2}$ & 0,00 & 0,13 & 0,28 \\
$\mathrm{Al}_{2} \mathrm{O}_{3}$ & 22,88 & 12,19 & 17,83 \\
$\mathrm{MgO}_{\mathrm{MnO}}$ & 4,86 & 17,27 & 5,80 \\
$\mathrm{Fe}_{2} \mathrm{O}_{3}$ & 0,04 & 0,16 & 0,11 \\
$\mathrm{CaO}$ & 3,06 & 7,71 & 6,08 \\
$\mathrm{Na}_{2} \mathrm{O}$ & 1,36 & 2,82 & 1,49 \\
$\mathrm{~K}_{2} \mathrm{O}$ & 4,30 & 1,41 & 3,67 \\
$\mathrm{~F}$ & 3,02 & 5,82 & 5,60 \\
$\mathrm{P}_{2} \mathrm{O}_{5}$ & nd & 2,06 & nd \\
$\mathrm{P.} \mathrm{fogo}_{\text {fogo }}$ & 0,09 & 1,25 & 0,23 \\
\end{tabular}

A Figura 6.1 mostra o difratograma de raios-X do minério ( $R O M)$ GP, no qual se pode observar que o minério é constituído pelos seguintes minerais: clinocloro, flogopita, talco, albita, berilo e molibdenita. 


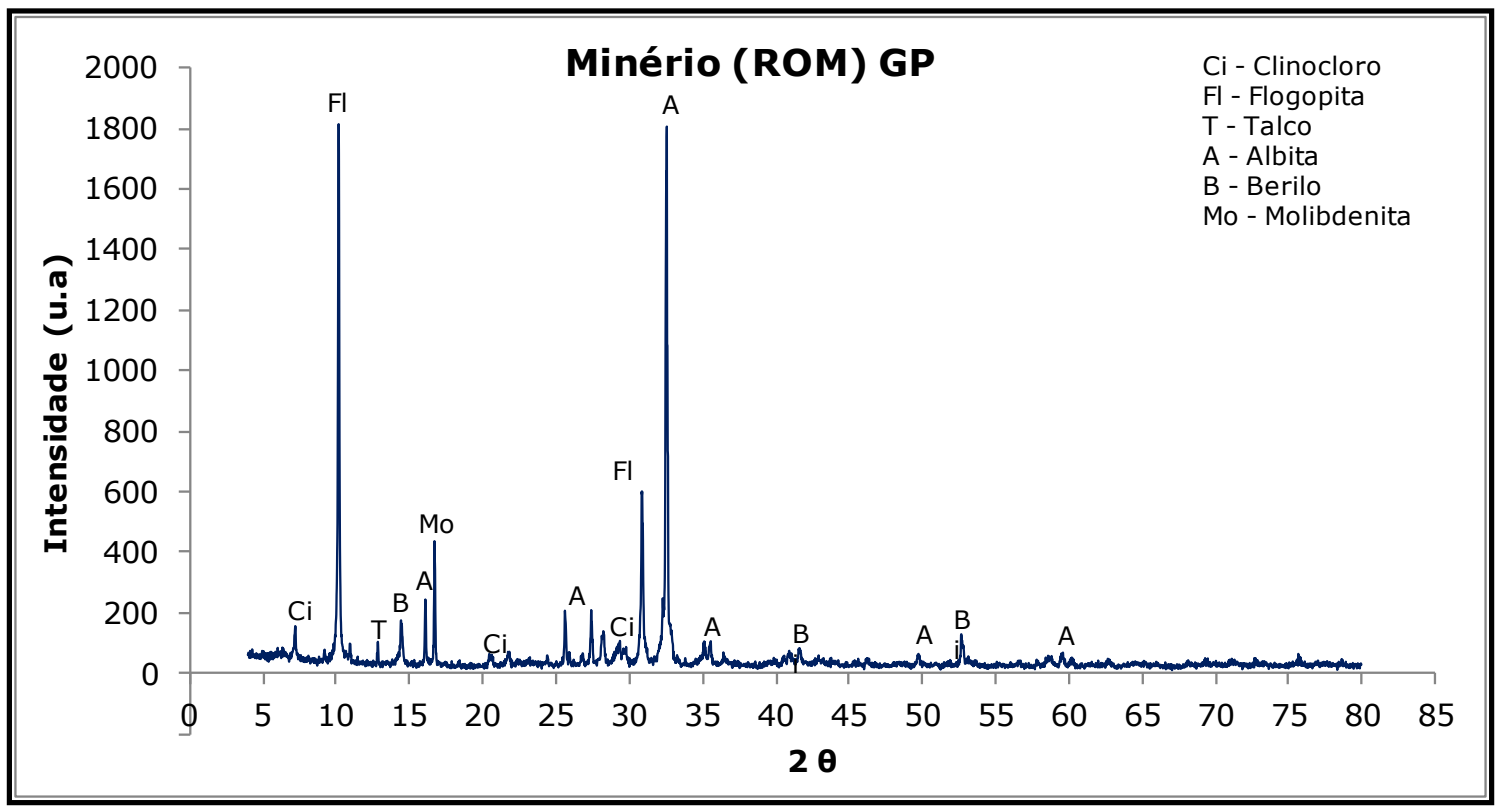

Figura 6.1 - Difratograma de raios- $X$ do minério (ROM) GP

O difratograma de raios-X do minério ( $R O M$ ) GM pode ser observado na

Figura 6.2. Os seus principais minerais constituintes são: flogopita, talco e albita.

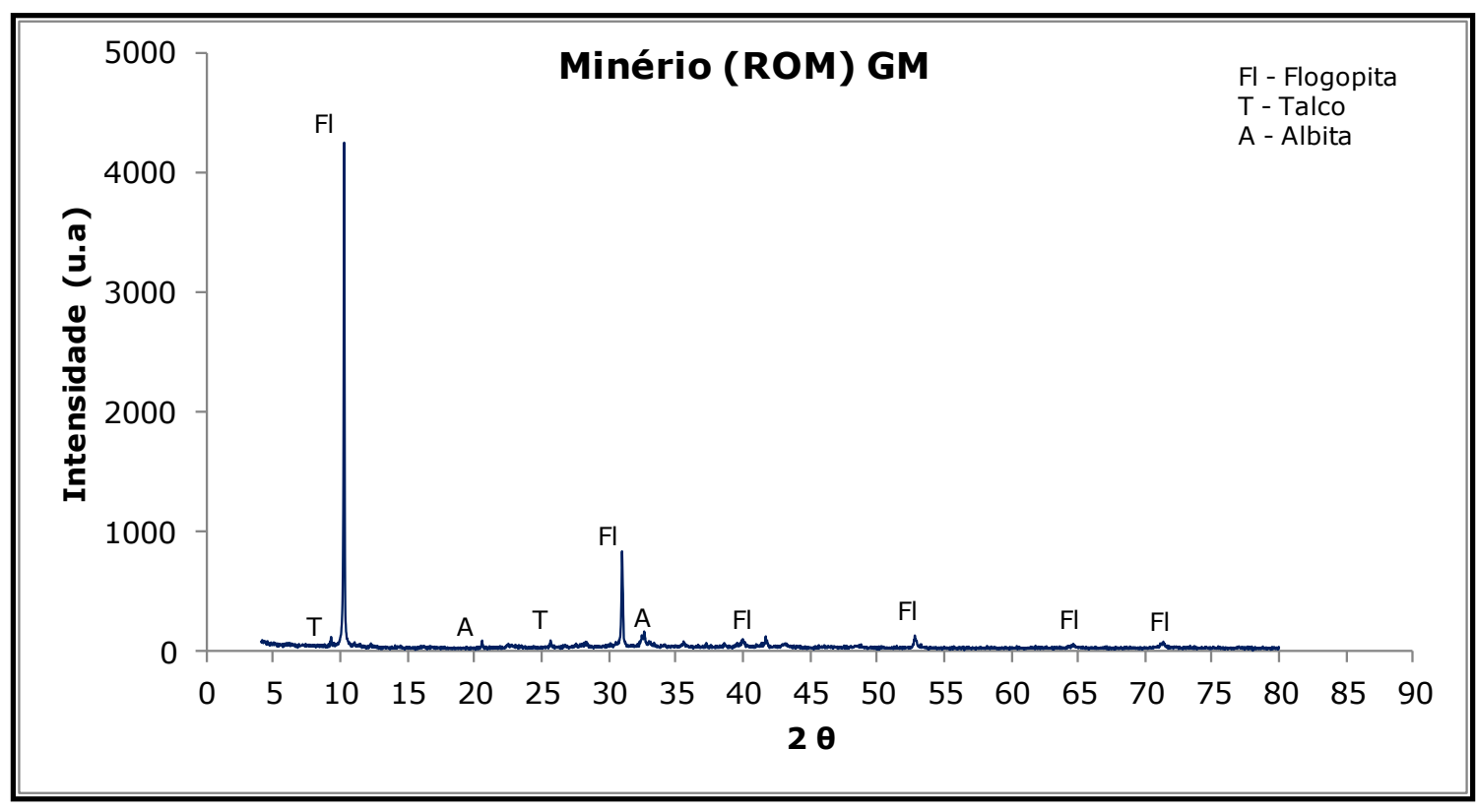

Figura 6.2 - Difratograma de raios-X do minério (ROM) GM

A Figura 6.3 mostra o difratograma de raios- $X$ do minério ( $R O M$ ) GF, no qual se pode observar que o minério é constituído pelos seguintes minerais: clinocloro, flogopita, molibdenita e albita. 


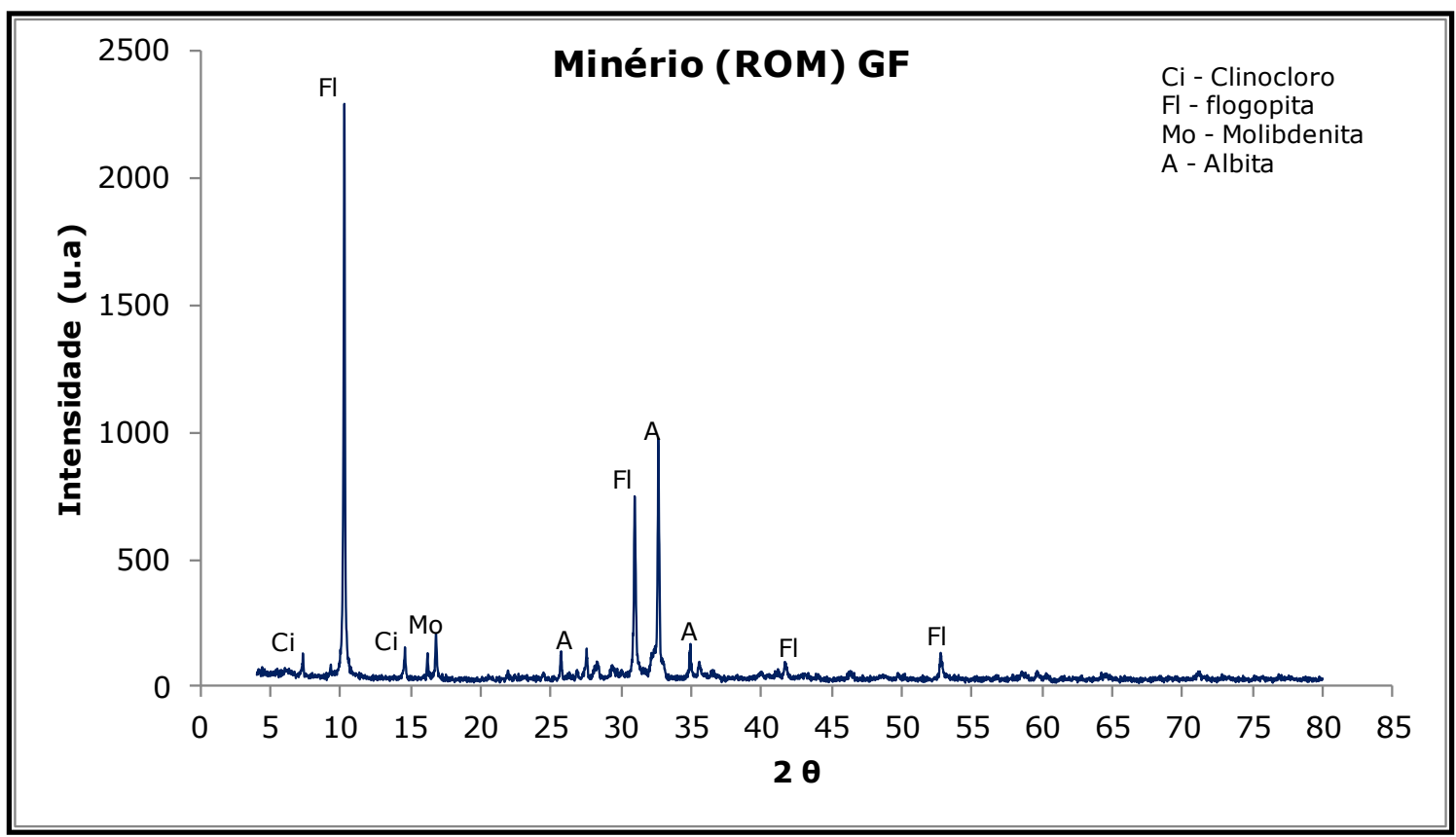

Figura 6.3 - Difratograma de raios-X do minério (ROM) GF

A liberação da molibdenita em relação à sua ganga foi calculada a partir da partição do elemento molibdênio para o produto afundado (ensaio de afunda-flutua) e observações dos produtos em lupa binocular. De modo geral, todos os minérios apresentaram grau de liberação semelhante. Na fração compreendida no intervalo 1000 × $600 \mu \mathrm{m}$ a liberação é de $90 \%$ e nas frações inferiores a $-295 \mu \mathrm{m}$ a molibdenita encontra-se totalmente liberada (Tabela 6.2). Nas partículas mais grossas, os minerais de ganga inclusos na molibdenita são relativamente inexpressivos em termos de massa e pouco afetam o balanço para cálculo de liberação. Nas frações mais finas, a molibdenita já se encontra liberada da ganga.

Tabela 6.2 - Liberação da molibdenita em relação aos minerais de ganga

\begin{tabular}{cccc}
\hline \multirow{2}{*}{ Granulometria $(\mu \mathrm{m})$} & \multicolumn{3}{c}{ Liberação $(\%)$} \\
\cline { 2 - 4 } & Amostra GP & Amostra GM & Amostra GF \\
\hline$-1000+600$ & 90 & 90 & 90 \\
+425 & 98 & 98 & 95 \\
+295 & 100 & 100 & 98 \\
+150 & 100 & 100 & 100 \\
\hline
\end{tabular}

\subsubsection{Amostras de Rejeitos}

Como pode ser observado na Tabela 6.3, o teor de molibdênio (ppm) e seu equivalente em $\mathrm{MoS}_{2}$ nos rejeitos coletados, é significativamente baixo, traduzindo a boa recuperação do processo de concentração utilizado. 
Tabela 6.3 - Análise química dos rejeitos da flotação

\begin{tabular}{ccc}
\hline & Mo (ppm) \\
\hline SE & ALL & TZ \\
$211\left(0,035 \% \mathrm{MoS}_{2}\right)$ & $162\left(0,027 \% \mathrm{MoS}_{2}\right)$ & $116\left(0,019 \% \mathrm{MoS}_{2}\right)$ \\
\hline
\end{tabular}

Na Figura 6.4 pode ser observado o difratograma de raios- $X$ do rejeito $A L L$, o qual indica a presença dos seguintes minerais: flogopita, berilo, clorita, albita, molibdenita (pico pouco significativo) e quartzo.

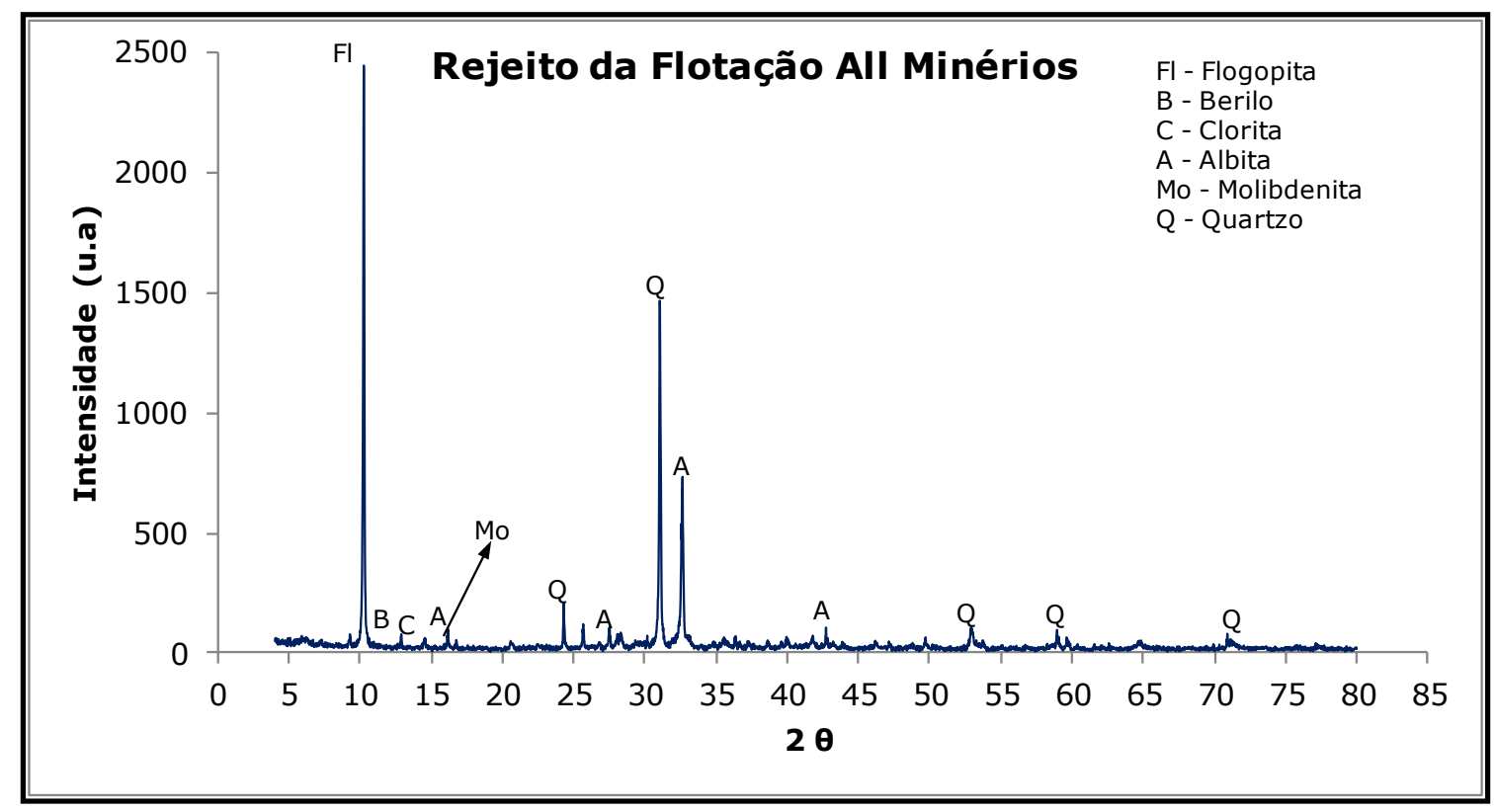

Figura 6.4 - Difratograma de raios-X do rejeito ALL

Os rejeitos de flotação da ALL, SE e TZ possuem distribuições granulométricas semelhantes $\left(\mathrm{P}_{80}=600 \mu \mathrm{m}\right)$, como pode ser observado na Figura 6.5 , indicando a necessidade de um aumento no tempo de moagem ou fechamento da grelha do moinho, de forma a atingir uma maior liberação da molibdenita e, consequentemente, maior recuperação. A similaridade encontrada na distribuição granulométrica dos rejeitos dos garimpos pode ser explicada pelo uso de equipamentos de cominuição comuns na região, isto é, o mesmo tipo de moinho de martelos empregado por todos pequenos mineradores que tem desempenhos semelhantes. 


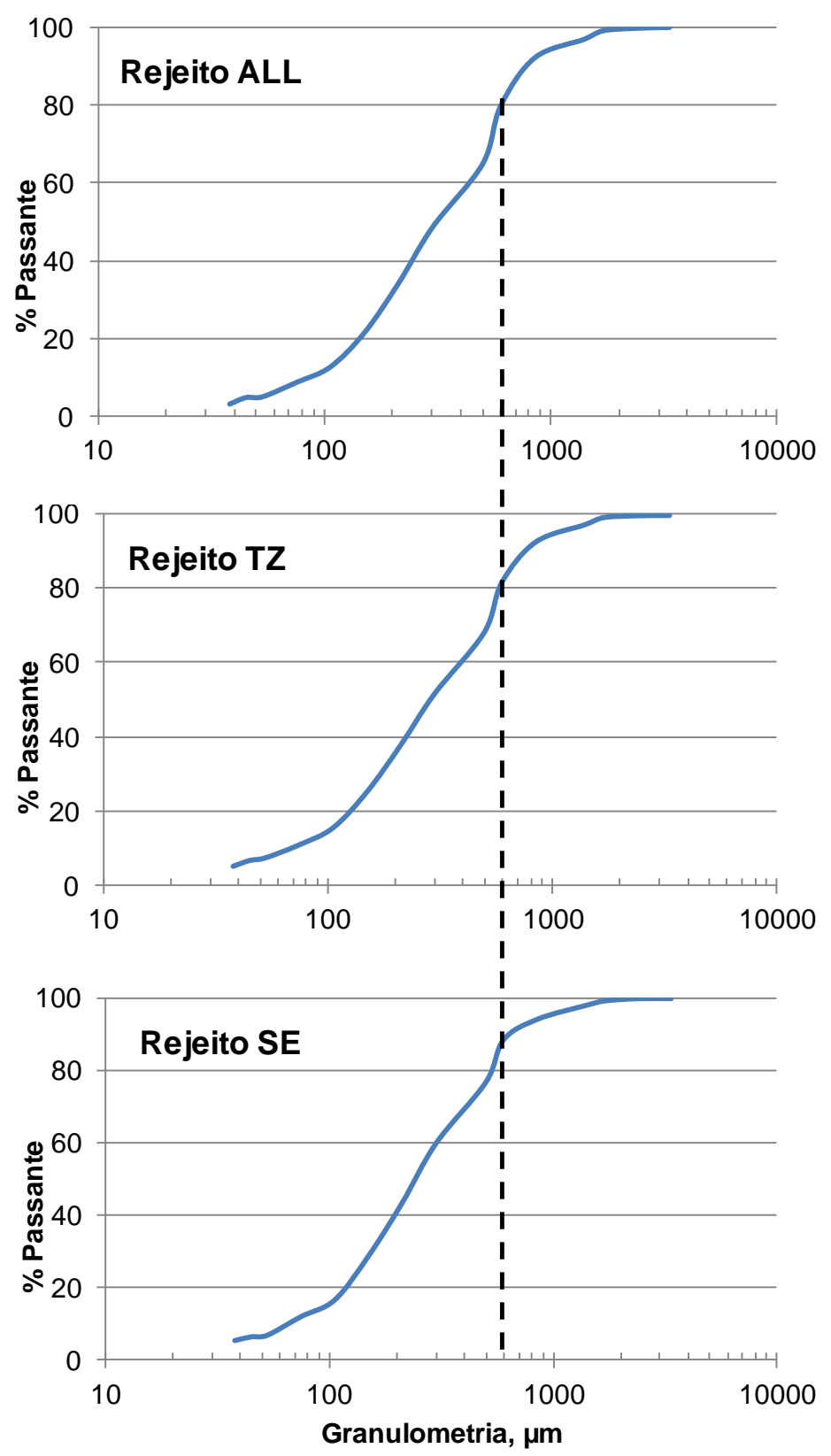

Figura 6.5 - Distribuição granulométrica dos rejeitos de flotação ALL, TZ e SE

6.1.1.3 Amostras de Concentrados de Molibdenita da Serra de Carnaíba

Os resultados de análise química dos concentrados de molibdenita coletados na Serra de Carnaíba estão apresentados na Tabela 6.4.

Tabela 6.4 - Análise química dos concentrados de molibdenita

\begin{tabular}{lcccccccccc}
\hline & $\mathrm{Na}_{2} \mathrm{O}$ & $\mathrm{MgO}$ & $\mathrm{Al}_{2} \mathrm{O}_{3}$ & $\mathrm{SiO}_{2}$ & $\mathrm{~K}_{2} \mathrm{O}$ & $\mathrm{CaO}$ & $\mathrm{Fe}_{2} \mathrm{O}_{3}$ & $\mathbf{M o S}_{2}$ & $\mathrm{Bi}_{2} \mathrm{O}_{3}$ & Total \\
\hline Conc. 3X & 0,15 & 3,9 & 4,1 & 10,0 & 1,5 & 0,43 & 2,4 & $\mathbf{7 7 , 3}$ & 0,15 & 99,93 \\
Conc. MM & 0,19 & 2,9 & 2,3 & 6,0 & 0,91 & 0,43 & 2,3 & $\mathbf{8 4 , 5}$ & 0,14 & 99,67 \\
Conc. ITA & 0,23 & 4,4 & 4,7 & 11,1 & 2,0 & 0,31 & 2,6 & $\mathbf{7 4 , 4}$ & 0,14 & 99,88 \\
\hline
\end{tabular}


Verifica-se na Tabela 6.4 que todos os concentrados analisados produzidos na Região de Campo Formoso/Pindobaçu continham teores de $\mathrm{MoS}_{2}$ inferiores a 90\%, que é o valor limite aceitável para o comércio internacional.

Em continuidade ao estudo de caracterização mineralógica, procedeu-se à separação em líquido denso (bromofórmio, $d=2,89$ ) do concentrado de molibdenita, na fração $-150+74 \mu \mathrm{m}$ (granulometria dos ensaios de flotabilidade). Após a separação das fases afundadas e flutuadas, as mesmas foram analisadas por difratometria de raios- $X$ e microscopia eletrônica de varredura.

A Figura 6.6 mostra uma imagem obtida no microscópio eletrônico de varredura para o concentrado de molibdenita afundado no bromofórmio. Verifica-se nesta imagem a estrutura lamelar da molibdenita totalmente liberada e o tamanho de suas partículas.

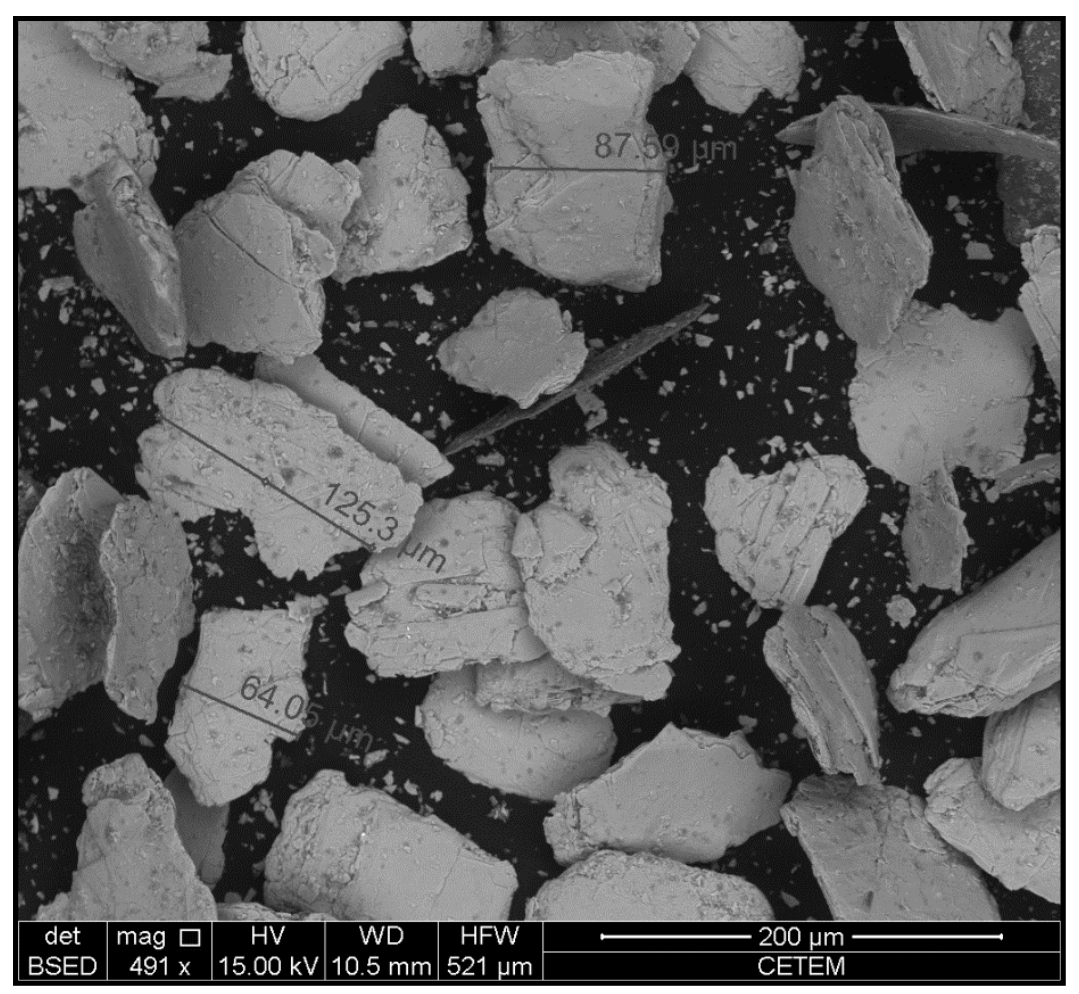

Figura 6.6 - Imagem de MEV da amostra do concentrado de molibdenita afundado no bromofórmio

A composição mineralógica do concentrado afundado foi determinada por meio de difratometria de raios-X. A presença de diversos picos característicos no difratograma mostrado na Figura 6.7 confirma a presença de molibdenita como principal mineral da fase afundada e evidencia a presença dos minerais contaminantes que diluem o seu teor. 


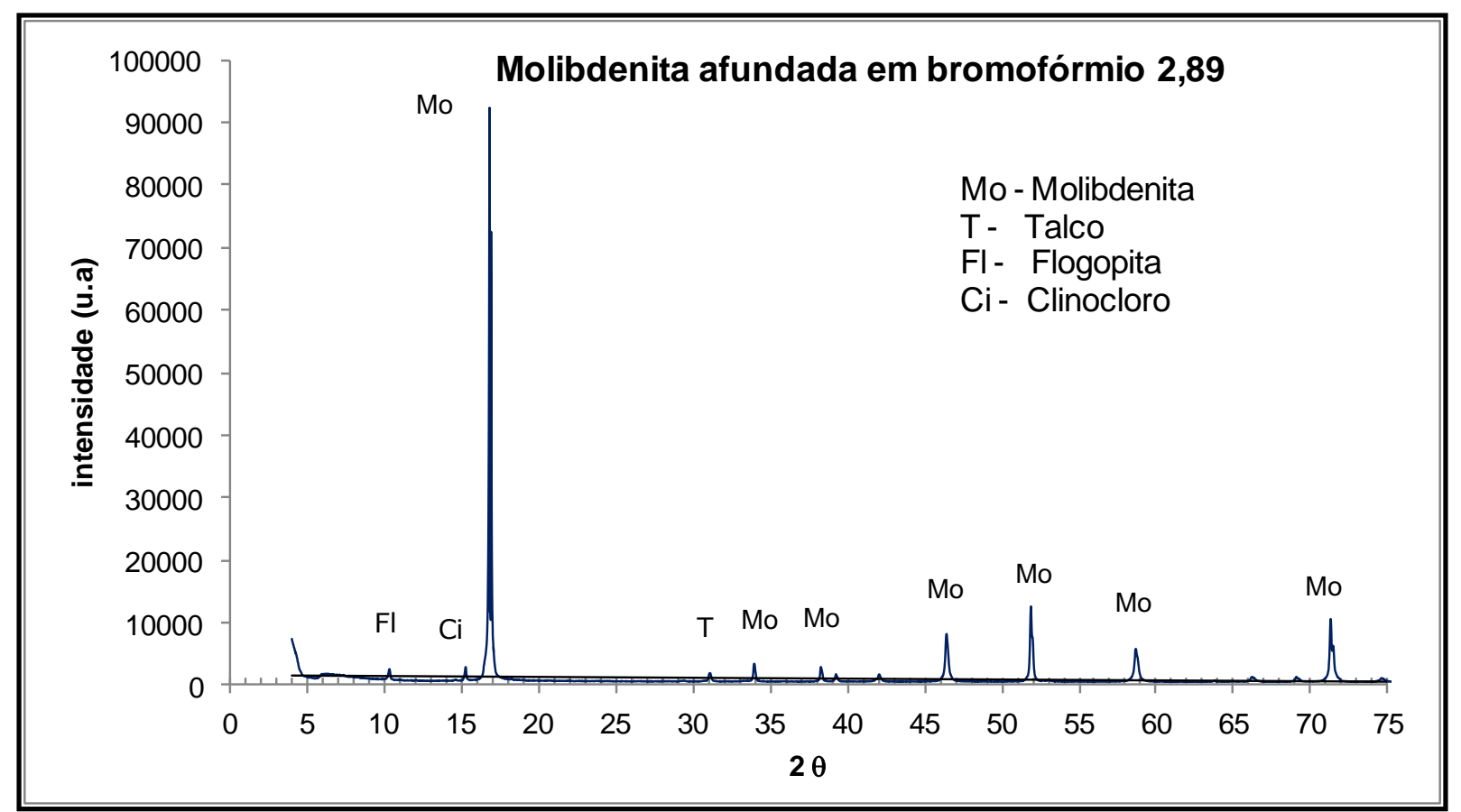

Figura 6.7 - DRX da amostra da molibdenita afundada no bromofórmio

A Figura 6.8 mostra uma imagem do concentrado de molibdenita flutuado no bromofórmio, obtida no microscópio eletrônico de varredura. Como se trata de uma imagem de elétrons retro-espalhados, os níveis de cinza são proporcionais ao número atômico médio da amostra a cada pixel e pesos atômicos mais elevados apresentam-se mais claros. Desta forma, o mineral mais claro é a molibdenita. Nesta amostra de minerais flutuados observa-se pouca molibdenita e a presença de diversos minerais hidrofóbicos como talco, grafite, flogopita, clorita e a presença de feldspato potássico (ortoclásio) e de berilo. 


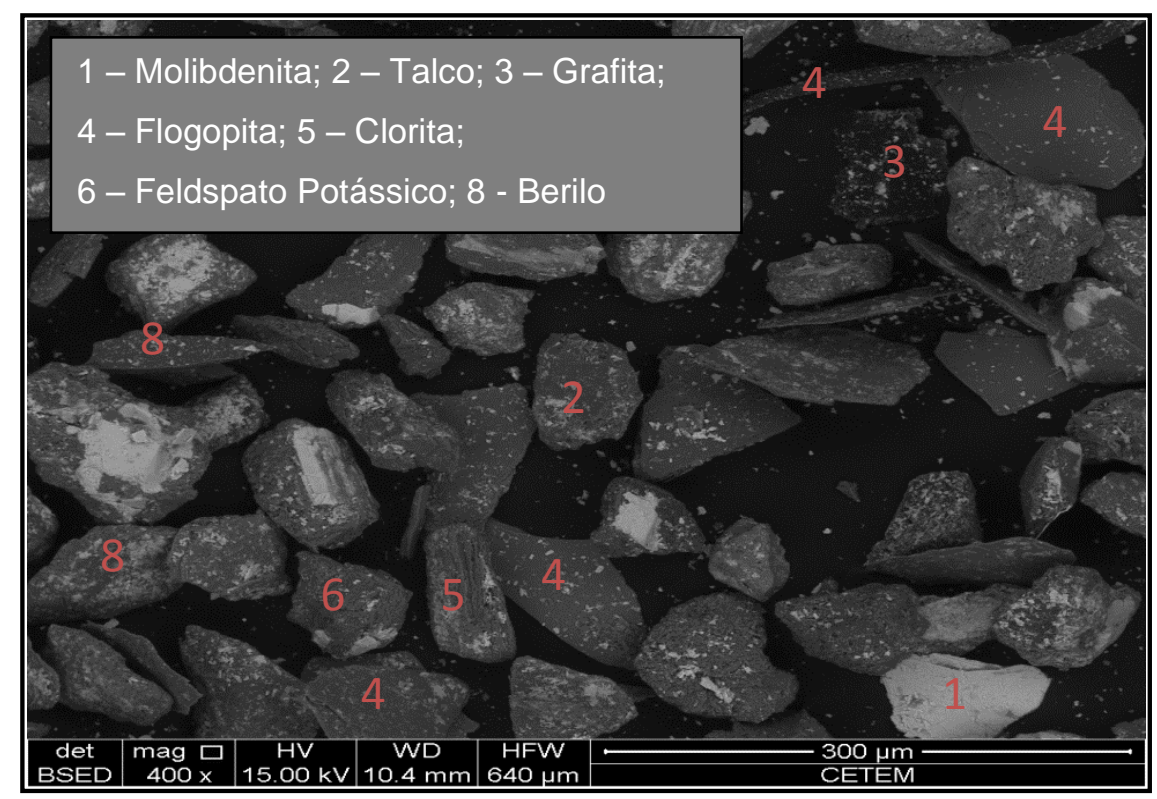

Figura 6.8 - Imagem de MEV dos minerais de ganga flutuados em bromofórmio

A composição mineralógica do produto flutuado foi determinada por meio da difratometria de raios-X. O difratograma de raios- $X$ da Figura 6.9 confirmou a presença de talco, flogopita, clinocloro e molibdenita no produto flutuado.

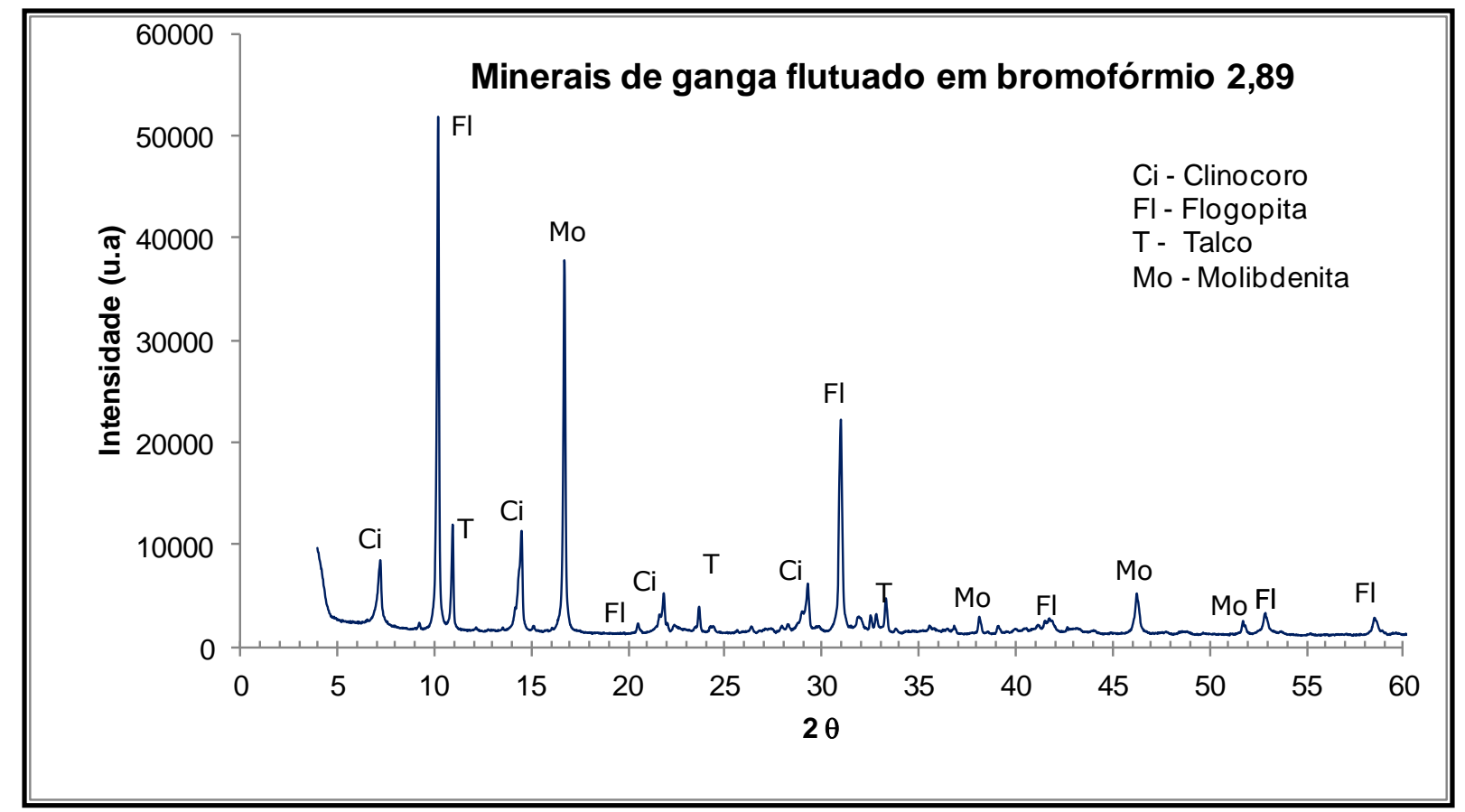

Figura 6.9 - DRX da amostra dos minerais de ganga flutuados em bromofórmio 
6.1.1.4 Análise Térmica (DTA/TG) do Concentrado de Molibdenita

A curva da Figura 6.10 apresenta as reações sofridas pela molibdenita quando submetida à calcinação oxidante em atmosfera de ar seco.

A curva de DTA mostra o início da oxidação da molibdenita na temperatura de $380^{\circ} \mathrm{C}$, conforme indicado pelo pequeno pico exotérmico nesta temperatura. Um grande pico exotérmico é observado na temperatura de $557^{\circ} \mathrm{C}$, representando a oxidação intensa da molibdenita (transformação do sulfeto de molibdênio em trióxido de molibdênio). Um pico médio endotérmico na temperatura de $763^{\circ} \mathrm{C}$ reflete a fusão e a sublimação do óxido de molibdênio. A partir desta temperatura inicia-se uma reação endotérmica contínua, representada pela vaporização do óxido de molibdênio, estabilizando-se na temperatura de $1050^{\circ} \mathrm{C}$.

A curva de TG mostra a perda de massa de 8,9\% equivalente à transformação de sulfeto de molibdênio em trióxido de molibdênio, na faixa de temperaturas entre 450 e $620^{\circ} \mathrm{C}$. Uma grande perda de massa (60\%) é observada entre as temperaturas de 620 e $1050^{\circ} \mathrm{C}$, que representa a vaporização/sublimação do óxido de molibdênio.

A oxidação da molibdenita por calcinação resulta na formação do óxido de molibdênio, que é uma das principais matérias-primas da indústria de molibdênio. $O$ óxido de molibdênio produzido tem a estrutura da molibdita $\left(\mathrm{MoO}_{3}\right)$ e cristaliza no sistema ortorrômbico na forma de cristais finos e alongados de coloração verde claro (ABDEL-REHIM, 1999). 


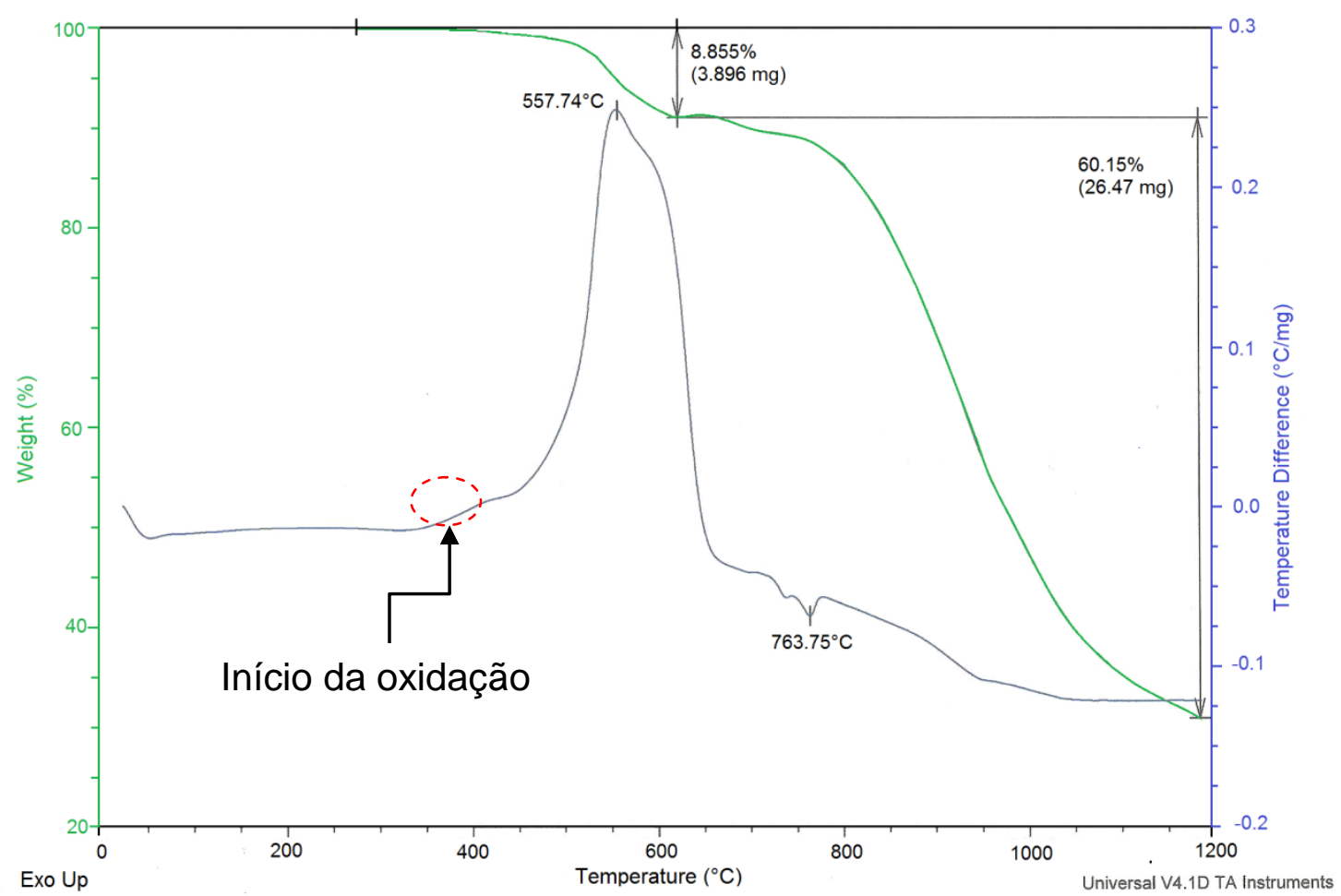

Figura 6.10 - Curva de DTA/TG do concentrado de molibdenita

\subsubsection{Determinação Experimental do "Work Index" de Bond (WI)}

Após a preparação do minério, realizada de acordo com a Figura 5.1 (item 5.1.1 Obtenção e Preparação das Amostras), procedeu-se à análise granulométrica do minério usado como alimentação na determinação experimental do WI.

A Figura 6.11 mostra a distribuição granulométrica do minério usado como alimentação. Utilizou-se o minério GP, por ser tratar de uma amostra mais representativa e por estar em maior quantidade, para atendimento aos requisitos dos ensaios de $W I$.

Os resultados das análises granulométricas evidenciaram um $\mathrm{P}_{80}=200 \mu \mathrm{m}$, que é um valor médio de granulometria dos produtos da moagem, conforme pode ser observado nas curvas da Figura 6.6, resultando no work index de Bond de 8,35 kWh/t curta, para a moagem do minério de Campo Formoso. 


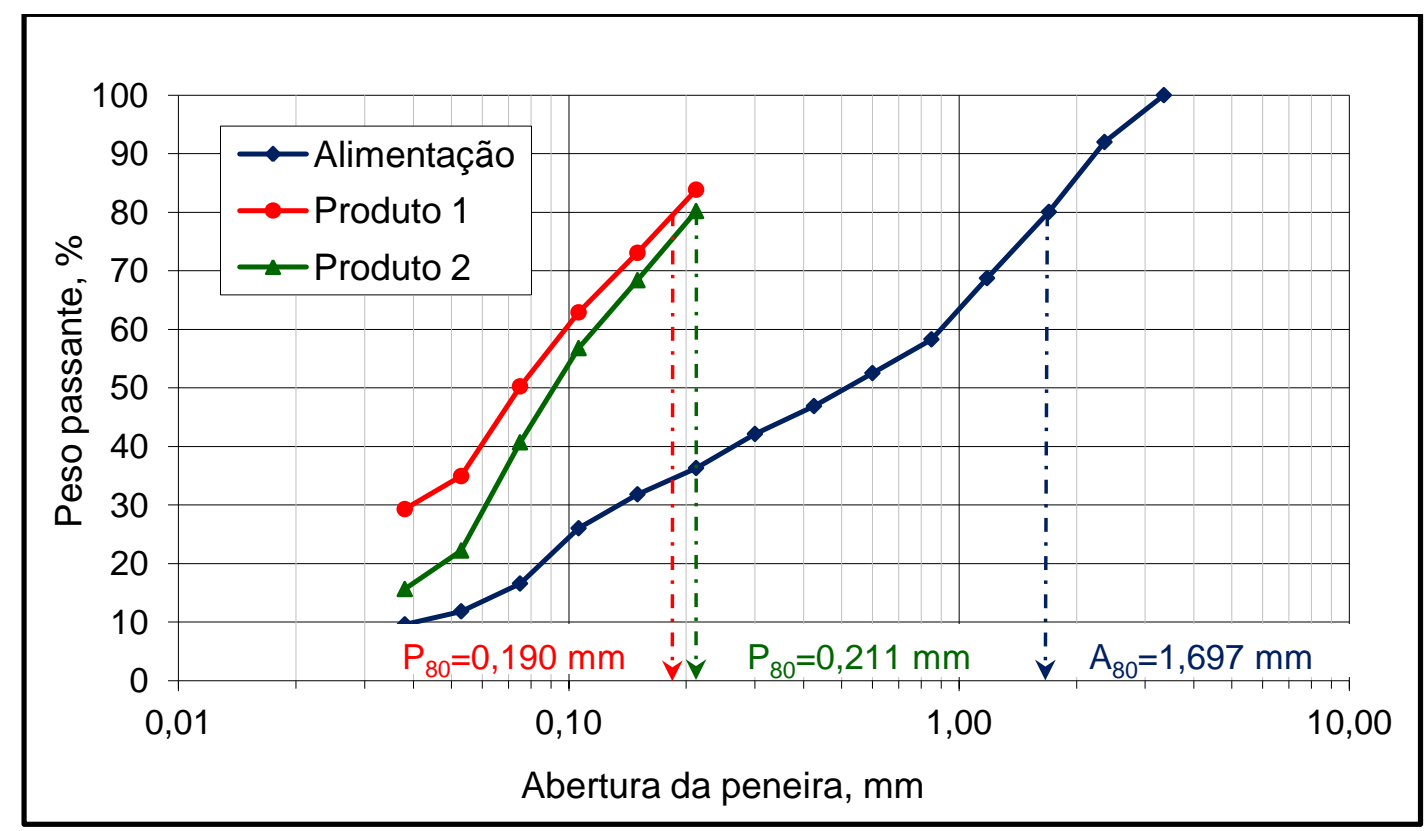

Figura 6.11 - Curva de distribuição granulométrica da alimentação e dos produtos

\subsubsection{Ensaios Preliminares de Beneficiamento dos Minérios de Molibdênio da Serra de Carnaíba}

Inicialmente foram realizados ensaios de moagem, com o objetivo de se determinar qual seria o tempo necessário para a cominuição da amostra dos minérios até 90\% menor que $295 \mu \mathrm{m}$, que é a granulometria de liberação da molibdenita.

\subsubsection{Estudos iniciais de concentração}

O minério cominuído nas condições apresentadas na seção anterior foi concentrado por flotação. Os ensaios de flotação realizados com o minério GF $\left(1,73 \% \mathrm{MoO}_{3}\right)$ propiciaram concentrados com $25 \%$ de Mo na etapa rougher e $45 \%$ de Mo na etapa cleaner. A recuperação metalúrgica do processo foi de $85 \%$.

Os ensaios de flotação realizados com os minérios GP $\left(0,21 \% \mathrm{MoO}_{3}\right)$ e $\mathrm{GM}$ $\left(0,57 \% \mathrm{MoO}_{3}\right)$ produziram concentrados com baixo teor de molibdênio ( $\left.20 \% \mathrm{Mo}\right)$, provavelmente devido à flotação conjunta de minerais hidrofóbicos como o talco e micas, normalmente presentes nesse tipo de minério, bem como, a realização de apenas uma etapa cleaner na flotação. 


\subsection{ESTUDOS FUNDAMENTAIS DE SEPARABILIDADE DO SISTEMA MOLIBDENITA/TALCO}

\subsubsection{Caracterização Mineralógica e Química da Molibdenita e do Talco}

A caracterização mineralógica e química da molibdenita e do talco encontrase apresentado no item 6.1.1.3. A sua utilização foi procedida de um tratamento específico (lixiviação com $\mathrm{HCl}$ e $\mathrm{KOH}$ e lavagem com água destilada) para retirada de impurezas superficiais.

O concentrado de talco (macrocristalino) utilizado neste trabalho foi fornecido pela Mineração Paranaense de Ponta Grossa, PR. A Figura 6.12 mostra a imagem realizada no microscópio eletrônico de varredura do concentrado do mineral talco utilizado nos ensaios de separabilidade molibdenita/talco. Verifica-se nesta imagem a estrutura lamelar do talco, o tamanho de suas partículas e a grande relação existente entre as faces e as bordas.

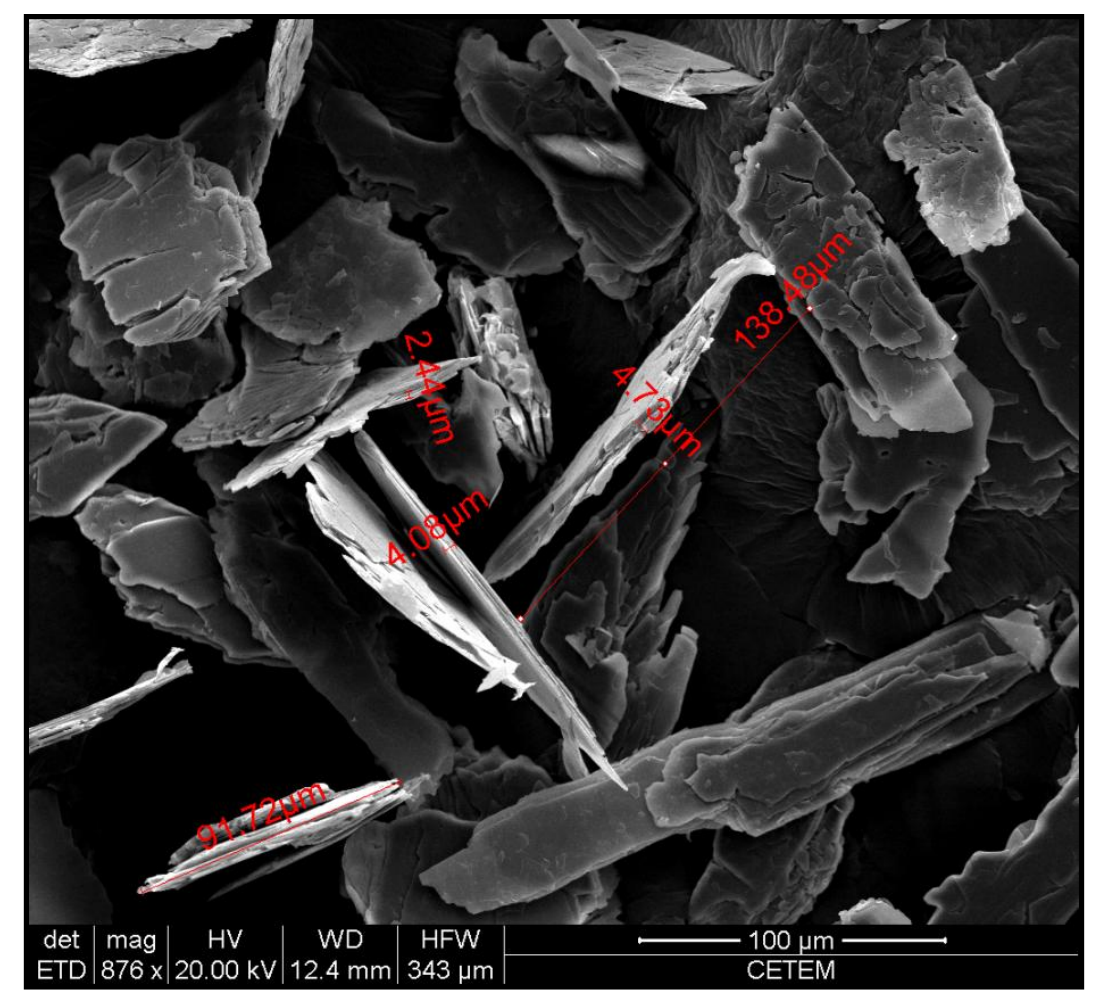

6.12 - Imagem de MEV da amostra de talco

A análise química do concentrado de talco realizada por fluorescência de raios-X está contida na Tabela 6.5. A alta pureza do talco é confirmada pelo fato dos resultados obtidos estarem em acordo com a composição teórica deste mineral que é de $31,7 \% \mathrm{MgO}, 63,5 \% \mathrm{SiO}_{2}$ e $4,8 \%$ de $\mathrm{H}_{2} \mathrm{O}$. 
Tabela 6.5 - Análise química do concentrado de talco

\begin{tabular}{ccccccccccccc}
\hline $\mathrm{ZnO}$ & $\mathrm{MgO}$ & $\mathrm{Al}_{2} \mathrm{O}_{3}$ & $\mathrm{SiO}_{2}$ & $\mathrm{~K}_{2} \mathrm{O}$ & $\mathrm{CaO}$ & $\mathrm{Fe}_{2} \mathrm{O}_{3}$ & $\mathrm{P}_{2} \mathrm{O}_{5}$ & $\mathrm{MnO}$ & $\mathrm{NiO}$ & $\mathrm{CuO}$ & P.F. & Total \\
\hline 0,01 & 31,79 & 0,82 & 61,77 & 0,03 & 0,35 & 0,23 & 0,01 & 0,02 & 0,01 & 0,01 & 4,96 & 100,01 \\
\hline
\end{tabular}

\subsubsection{Distribuição de tamanho de partículas e cinética de flotação}

As distribuições granulométricas das amostras de molibdenita e talco foram determinadas no granulômetro Master Size da Malvern Instruments. A amostra de talco foi britada e cominuída em gral de porcelana até uma granulometria inferior a $150 \mu \mathrm{m}$. A amostra do concentrado de molibdenita já se encontrava com granulometria inferior a $150 \mu \mathrm{m}$. A Figura 6.13 mostra a distribuição granulométrica das amostras de molibdenita e talco e os respectivos $d_{50}(73 \mu \mathrm{m}$ molibdenita; $49 \mu \mathrm{m}$ talco).

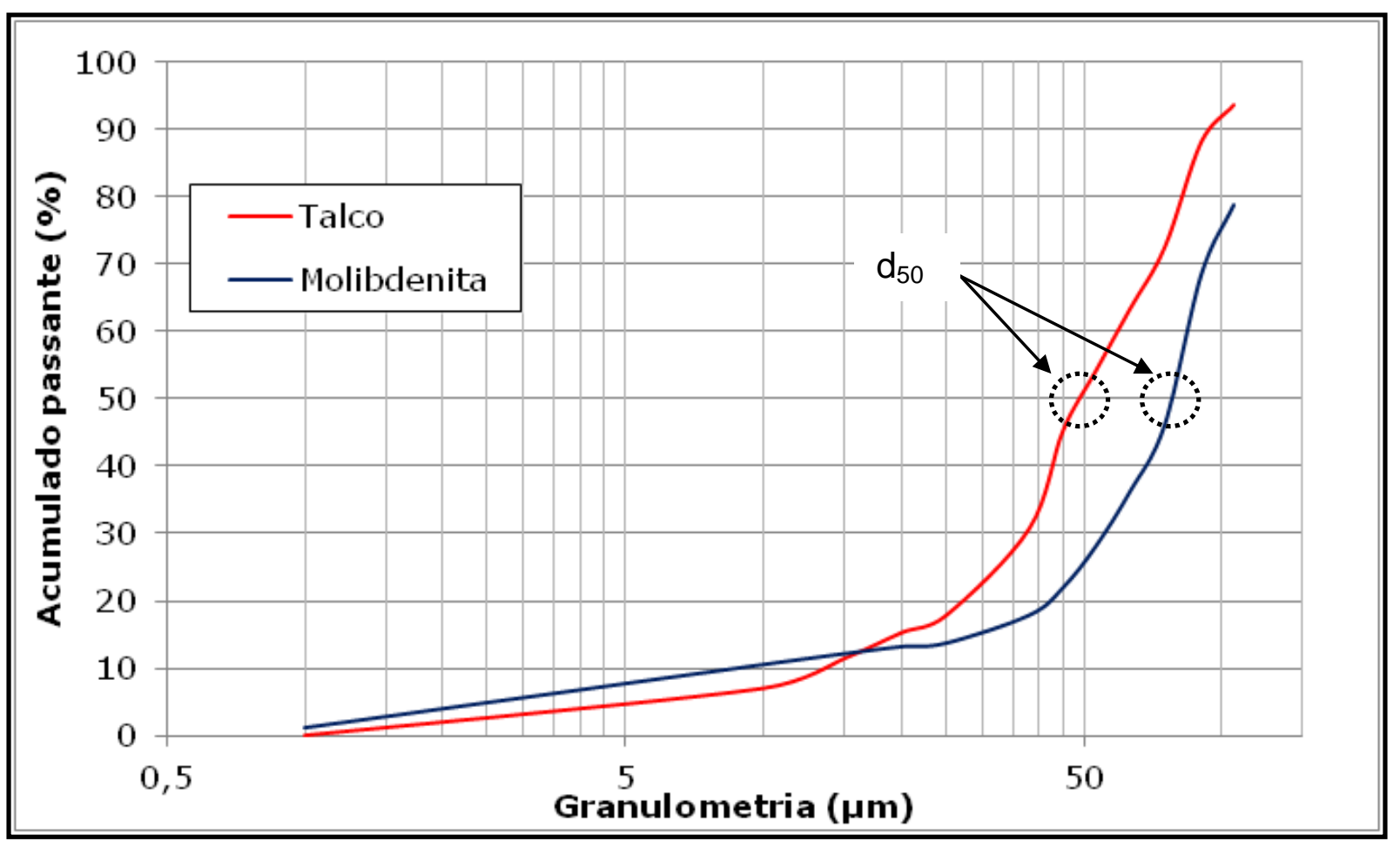

Figura 6.13 - Distribuição granulométrica das amostras de molibdenita e talco

A cinética de flotação das amostras de molibdenita e talco, cujas distribuições granulométricas estão contidas na Figura 6.13, está apresentada na Figura 6.14. Estes ensaios foram realizados em célula Partridge \& Smith, para um tempo máximo de flotação de $240 \mathrm{~s}$. 


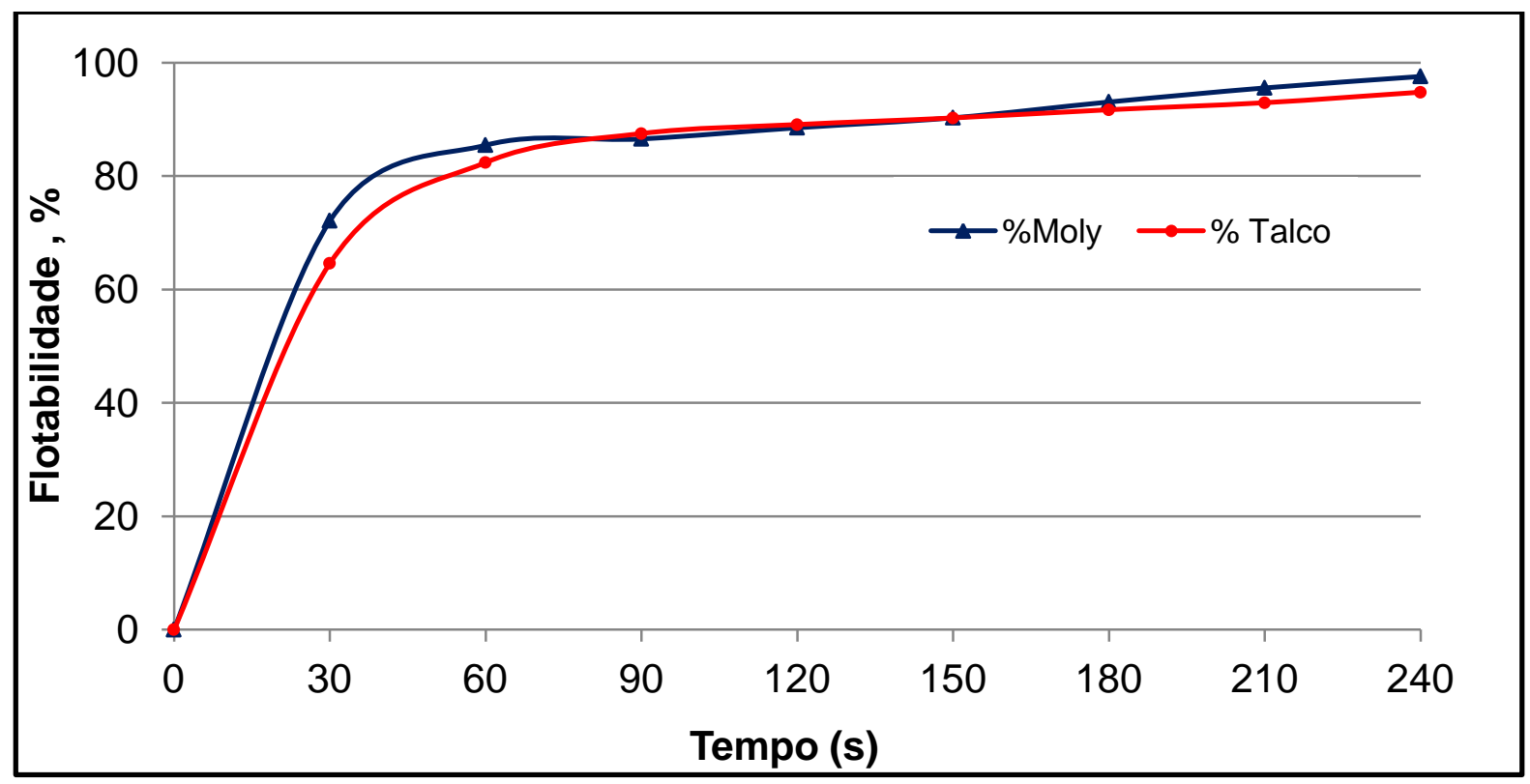

Figura 6.14 - Cinética de flotação da molibdenita e do talco para um tempo de $240 \mathrm{~s}$

As curvas cinéticas de flotação apresentadas na Figura 6.14 são muito semelhantes para as duas espécies minerais (molibdenita e talco) e seguem o modelo de primeira ordem, definido pela Equação 6.1.

$$
\frac{d C_{t}}{d t}=-k C_{t} \quad \Rightarrow \quad C_{t}=C_{o} \exp (-k t) \quad \text { Equação } 6.1
$$

Onde:

$\mathrm{C}_{\mathrm{o}}$ e $\mathrm{C}_{\mathrm{t}}$ são as concentrações de molibdenita e talco na polpa mineral no tempo inicial e em um tempo t qualquer;

$k$ é a constante de flotação de primeira ordem $\left(\mathrm{s}^{-1}\right) \mathrm{e}$

té o tempo, em segundos.

Os resultados apresentados na Figura 6.14 encontram-se de acordo com os estudos realizados por Raghavan e Hsu (1984), onde os autores avaliaram os fatores que afetam a recuperação de molibdenita, por flotação, contida em minérios de cobre pórfiros.

\subsubsection{Efeito do tamanho de partícula}

Para a realização dos ensaios de flotabilidade em função do tamanho de partícula, a amostra de molibdenita foi lixiviada com $\mathrm{KOH}$ e posteriormente com $\mathrm{HCl}$ para retirada de qualquer produto contaminante (coletores residuais, oxidações na 
superfície, etc) remanescente no concentrado. A influência do tamanho de partícula na flotabilidade da molibdenita e do talco foi investigada utilizando-se amostras dos minerais nos seguintes intervalos granulométricos: $-150+74 \mu \mathrm{m} ;-74+37 \mu \mathrm{m}$ e -37 $\mu \mathrm{m}$. Verificou-se a diminuição na flotabilidade (recuperação), cerca de $20 \%$, tanto para a molibdenita quanto para o talco, para as três faixas granulométricas estudadas, conforme mostrado na Figura 6.15.

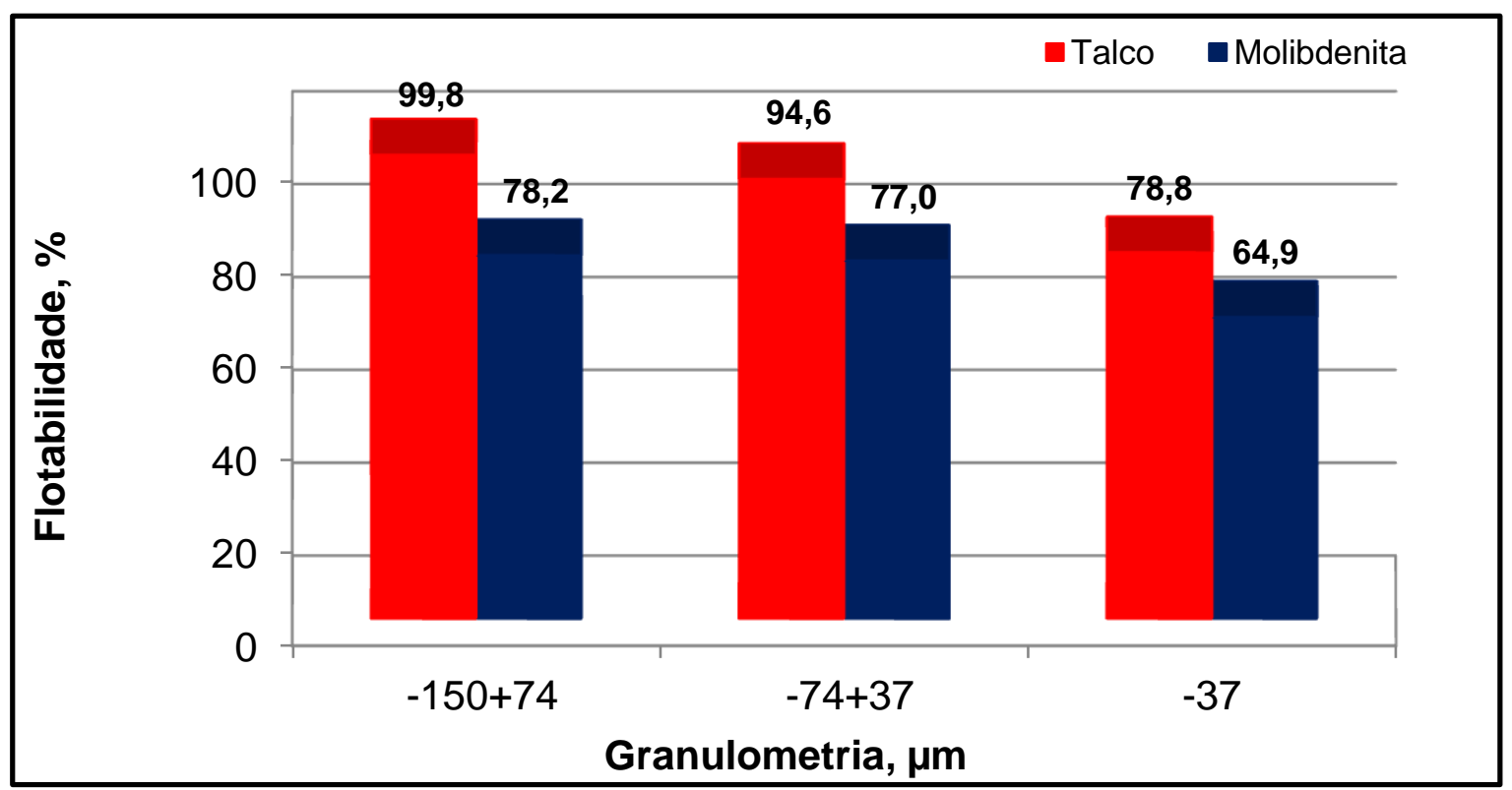

Figura 6.15 - Flotabilidade em função do tamanho da partícula

A redução significativa da flotabilidade dos minerais molibdenita e talco é devido à diminuição da hidrofobicidade de ambos minerais que é intrínseca à relação faces:bordas. Conforme comentado no item 4.12.3, esses minerais apresentam uma anisotropia em relação às suas superfícies, sendo suas faces responsáveis pela propriedade hidrofóbica e as bordas pela propriedade hidrofílica.

A Tabela 6.6 apresenta os resultados da medida de área superficial realizada no equipamento Mastersizer 2000, em função do tamanho das partículas dos minerais, corroborando com a redução da flotabilidade. À medida que o tamanho das partículas diminui, ocorre a redução da relação faces:bordas, inferindo a diminuição na hidrofobicidade e, consequentemente, na sua flotabilidade natural.

Tabela 6.6 - Área superficial das partículas de molibdenita e talco

\begin{tabular}{cccc}
\hline Mineral & \multicolumn{3}{c}{ Área superficial $\mathrm{m}^{2} / \mathrm{g}$} \\
& $-150+74 \mu \mathrm{m}$ & $-74+37 \mu \mathrm{m}$ & $-37 \mu \mathrm{m}$ \\
\hline Molibdenita & 0,082 & 0,449 & 0,539 \\
Talco & 0,125 & 0,212 & 0,461 \\
\hline
\end{tabular}


No estudo "O Efeito do Tamanho da Partícula sobre a Energia de Superfície e Molhabilidade da Molibdenita", realizado por Castro e Correa (1995), ficou demonstrado pelos valores da componente polar da tensão superficial $\left(\gamma s^{p}\right)$, que amostras de granulometria mais fina da molibdenita são mais polares (hidrofílicas) do que frações mais grosseiras. Estes resultados confirmaram que a diminuição da relação faces:bordas promove a perda de flotabilidade das frações mais finas e polares da molibdenita, devido à interação das bordas do mineral com a água, por meio de forças polares.

\subsubsection{Ensaios de Flotabilidade da molibdenita e talco em célula Partrigde \& Smith com variação de pH e sem agente depressor}

Os gráficos de flotabilidade da molibdenita e do talco em função do pH sem a utilização de um reagente depressor estão representados na Figura 6.16. Verifica-se que a variação do $\mathrm{pH}$ não exerce nenhum efeito depressor sobre a superfície do talco, mantendo estável sua hidrofobicidade natural. Esses resultados encontram-se alinhados com o estudo realizado por Rath et al (1997) onde ficou evidenciado que a recuperação por flotação do talco é independente do $\mathrm{pH}$.

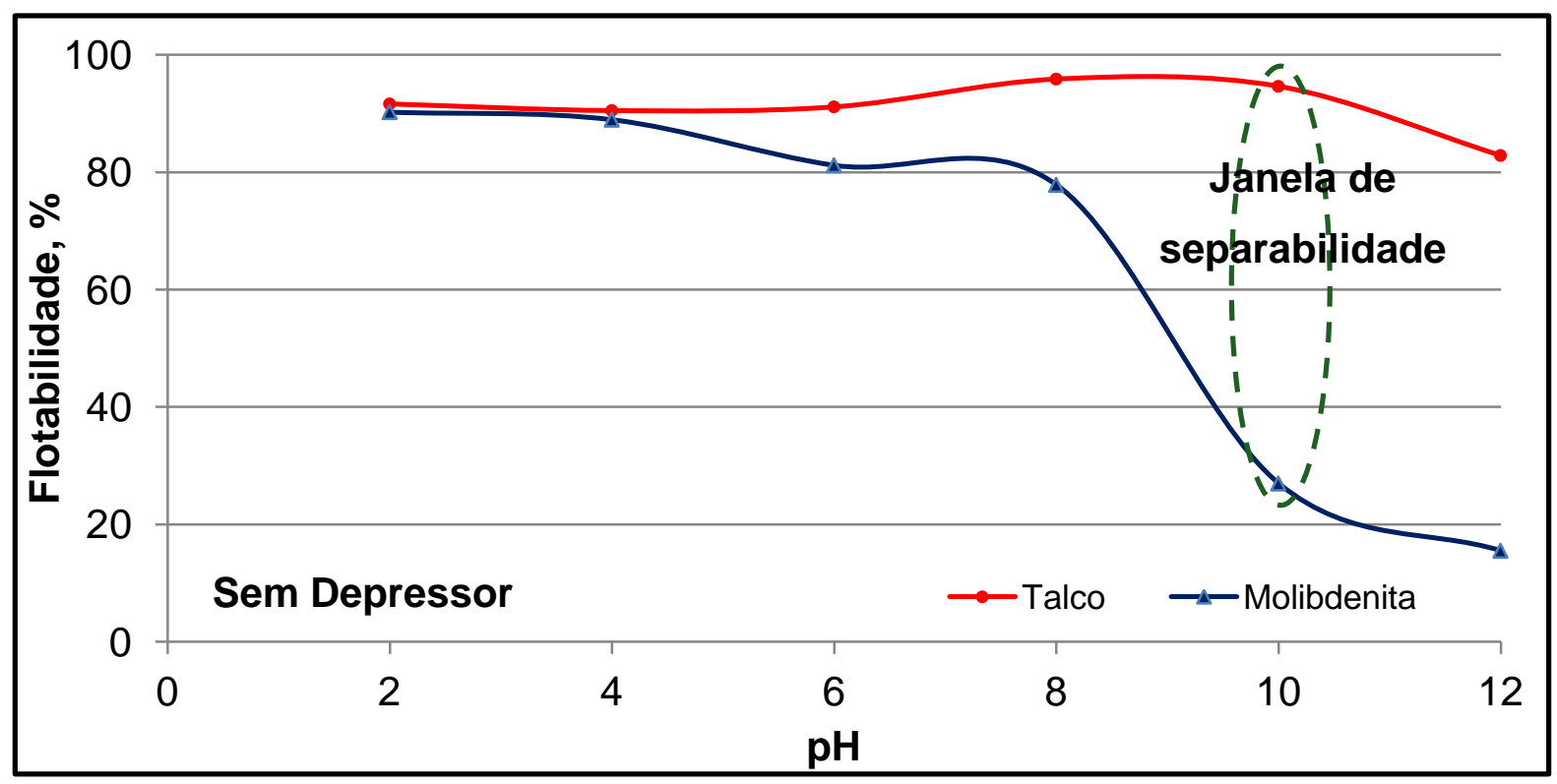

Figura 6.16 - Influência do pH na flotabilidade natural da molibdenita e do talco

A flotabilidade da molibdenita na ausência de qualquer depressor é afetada pela oxidação de sua superfície $\left(\mathrm{MoO}_{3}\right)$. O gráfico contido na Figura 6.16 mostra a redução acentuada na recuperação da molibdenita por flotação na região alcalina de pH. Chander e Fuerstenau (1972) postularam que a redução na flotabilidade é 
devido à presença de cargas elétricas contidas nas bordas da molibdenita,

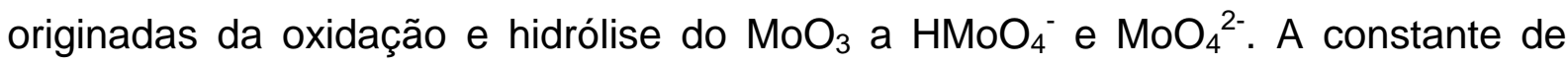
equilíbrio, pK, para a dissociação do $\mathrm{HMoO}_{4}{ }^{-}$a $\mathrm{MoO}_{4}{ }^{2-}$ (Equação 6.2) é obtida em torno do $\mathrm{pH} 6$ e, portanto, os íons molibdato estarão duplamente carregados e serão a espécie predominante em valores de $\mathrm{pH}$ superiores.

$$
\mathrm{HMoO}_{4}{ }^{-} \Leftrightarrow \mathrm{H}^{+}+\mathrm{MoO}_{4}{ }^{2-}, \mathrm{pK}=5,95 \quad \text { Equação } 6.2
$$

Essa mudança pode ser observada no diagrama de Pourbaix (com a região de estabilidade da molibdenita em destaque) para as espécies de molibdênio contido em soluções aquosas (Figura 6.17).

As mudanças nas espécies dos íons molibdato $\left(\mathrm{HMoO}_{4}{ }^{-}\right.$e $\left.\mathrm{MoO}_{4}{ }^{2-}\right)$ em solução e na superfície da molibdenita são responsáveis pela redução na sua flotabilidade, face ao aumento da sua hidrofilicidade. $O$ aumento da eletronegatividade nas bordas da molibdenita pode ser observado nas curvas de potencial zeta contidas nas Figuras 6.26 e 6.30, e corroborado pelo diagrama da Figura 6.17, em que o potencial é mais negativo quando o meio é mais alcalino. 


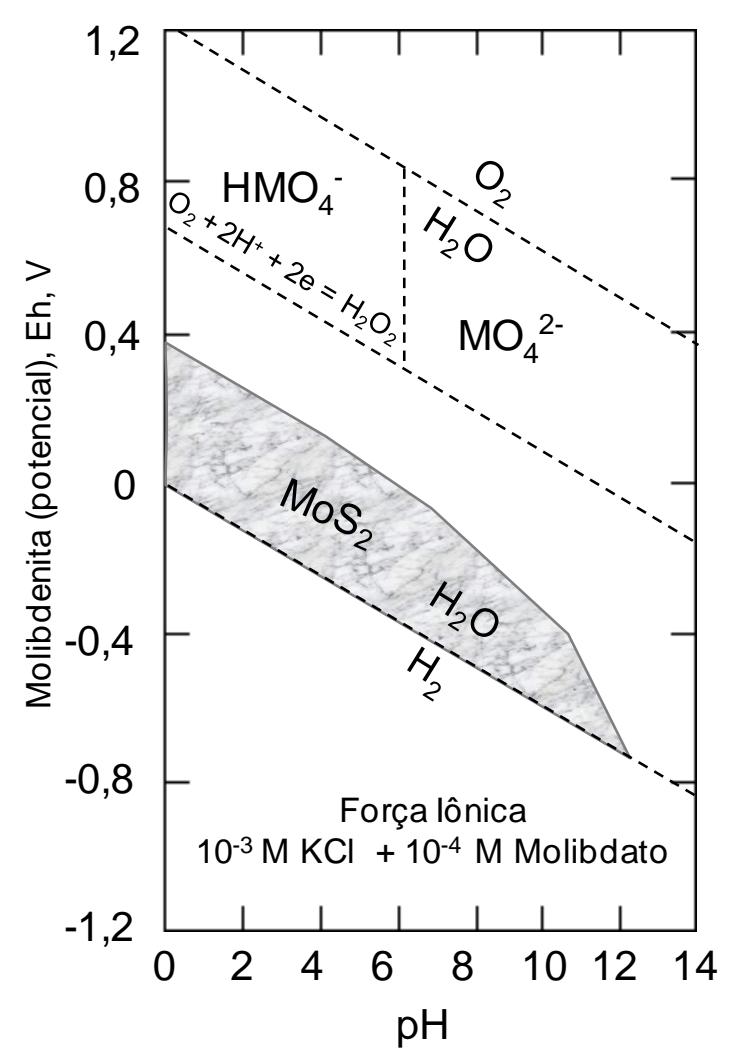

Figura 6.17 - Diagrama de Pourbaix para o molibdênio (adaptada de CHANDER; FUERSTENAU, 1972)

Estudos recentes (LÓPES-VALDIVIESO et al., 2012; TABARES et al., 2006;) sobre a morfologia das faces e bordas da molibdenita com uso de imagens capturadas em microscópio de força atômica (MFA) (Figura 6.18) mostraram que a superfície do mineral (plano basal) é constituída por microcristais com microfaces e microbordas, que são responsáveis pela sua hidrofobicidade. $\mathrm{O}$ aumento do $\mathrm{pH}$ e o aumento do potencial zeta são devidos à formação de espécies iônicas de molibdato nas bordas e nas microbordas presentes nas faces da molibdenita. Devido a esta relação face:bordas a hidrofobicidade e consequente flotabilidade das partículas da molibdenita diminui em meio alcalino. 


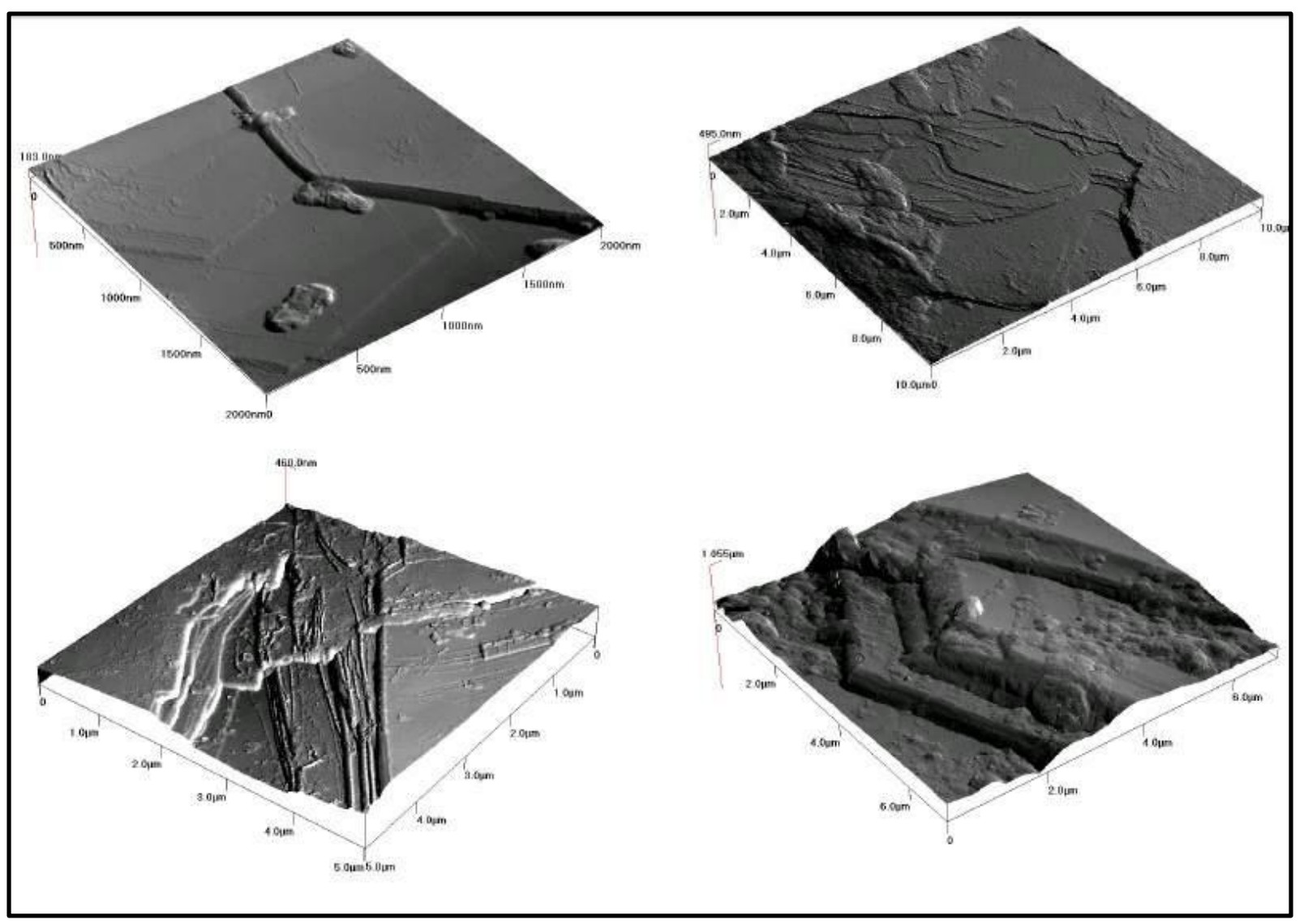

Figura 6.18. - Imagens de MFA em diferentes áreas da face da molibdenita nos tamanhos 10x10, 6X6, 5x5 e 2x2 $\mu \mathrm{m}$ (LÓPEZ-VALDIVIESO et al., 2012)

\subsubsection{Ensaios de Flotabilidade da molibdenita e talco em célula Partrigde \& Smith com agente depressor}

Os ensaios de flotabilidade da molibdenita e do talco com variação de pH foram realizados com adição de reagentes depressores previamente selecionados em função da revisão bibliográfica realizada. Foram utilizados reagentes depressores orgânicos como polímeros aniônicos (carboximetil celulose e ácido húmico), não iônicos (goma guar, amido, quebracho e dextrina) e um depressor inorgânico (silicato de sódio).

Nesta série de ensaios a concentração da solução do depressor foi mantida fixa em 100 ppm e o pH foi ajustado com o uso de soluções de $\mathrm{KOH}$ e $\mathrm{HCl}$ diluídas. A concentração da solução do espumante (MIBC) foi fixada em 100 ppm.

A flotabilidade, expressa pela relação mássica entre o produto flotado e a soma dos produtos flotado e afundado (recuperação em massa), foi calculada segundo a Equação 5.1. Foi estabelecido como critério de separabilidade molibdenita/talco, uma diferença superior a 50\% (janela de separabilidade) entre as flotabilidades de cada mineral. 
A Figura 6.19 mostra os resultados do teste de flotabilidade no qual se utilizou a CMC, polímero aniônico, como agente depressor. Não foi verificada diferença (janela) entre as separabilidades dos minerais acima de 50\%, embora seja reportado na literatura que a CMC tem um efeito depressor sobre o talco (GOMES; OLIVEIRA, 1991). Gomes (1988) reporta que a depressão do talco com CMC pode ser reforçada pela presença de cloreto de alumínio na polpa mineral, promovendo um aumento da densidade de adsorção no intervalo de pH entre 4 e 5, aumentando o efeito depressor.

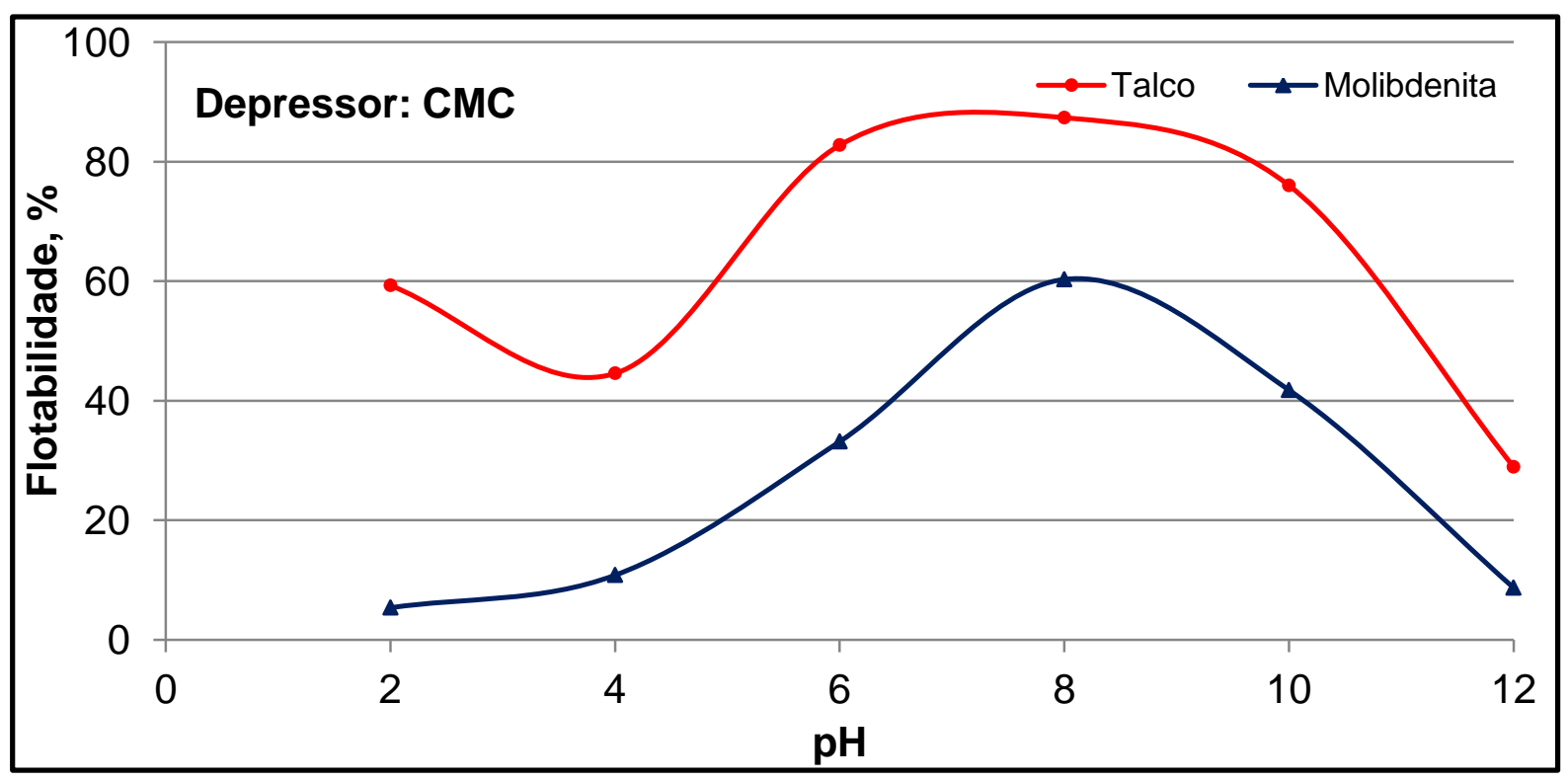

Figura 6.19 - Influência do $\mathrm{pH}$ na flotabilidade da molibdenita e do talco na presença de $\mathrm{CMC}$

A Figura 6.20 mostra os resultados do teste de flotabilidade no qual se utilizou a goma guar, polímero aniônico, como agente depressor. Não foi verificada diferença (janela) entre as separabilidades dos minerais acima de 50\%. As curvas de flotabilidade da molibdenita e talco, apresentadas na Figura 6.20, mostraram tendência de paralelismo, evidenciando um efeito depressor eficaz em ambos os minerais, porém sem abertura de uma janela de separação.

Nos estudos eletrocinéticos de adsorção e de flotação realizados por Rath et al (1999) para verificar a interação da goma guar com minerais hidrofóbicos e lamelares, como o talco, a mica e a grafita, ficou demonstrado que a densidade de adsorção da goma guar sobre os minerais hidrofóbicos é basicamente independente do $\mathrm{pH}$, como pode ser observado na Figura 6.20. O mecanismo de adsorção é 
regido por ligações de pontes de hidrogênio e interações químicas (RATH et al, 1997).

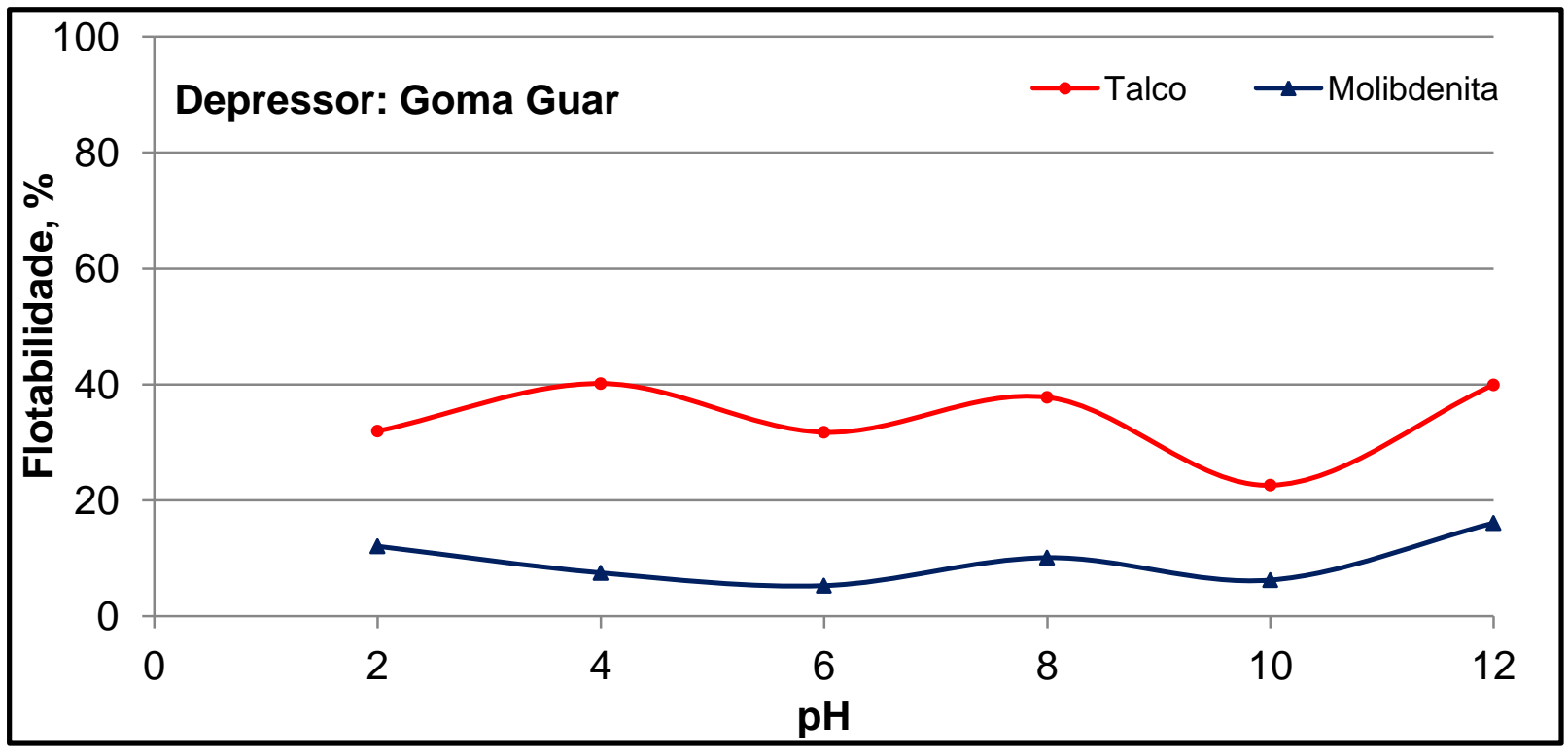

Figura 6.20 - Influência do pH na flotabilidade da molibdenita e do talco na presença de goma guar

A Figura 6.21 mostra os resultados do teste de flotabilidade no qual se utilizou o amido, polímero não iônico, como agente depressor. Não foi verificada diferença (janela) entre as separabilidades dos minerais acima de 50\%. A curva de flotabilidade da molibdenita apresentou comportamento constante, independente da variação do $\mathrm{pH}$; já a curva de flotabilidade do talco apresentou uma tendência de queda com o aumento do $\mathrm{pH}$. Uma pequena janela de separabilidade foi verificada em $\mathrm{pH} 2$, porém fora do critério adotado neste trabalho, de $50 \%$ de separabilidade. O amido, por ser um polímero orgânico de alto peso molecular (700.000 Da), é pouco seletivo no caso de separação de minerais naturalmente hidrofóbicos, com características de superfície semelhantes.

Beattie et al. (2006) reportam que o mecanismo de adsorção para o sistema amido-talco é realizado principalmente por interações hidrofóbicas entre os monômeros de D-glicose (monômero do amido) e as faces hidrofóbicas do talco. Em menor proporção, as bordas hidrofílicas também contribuem no processo de adsorção. 


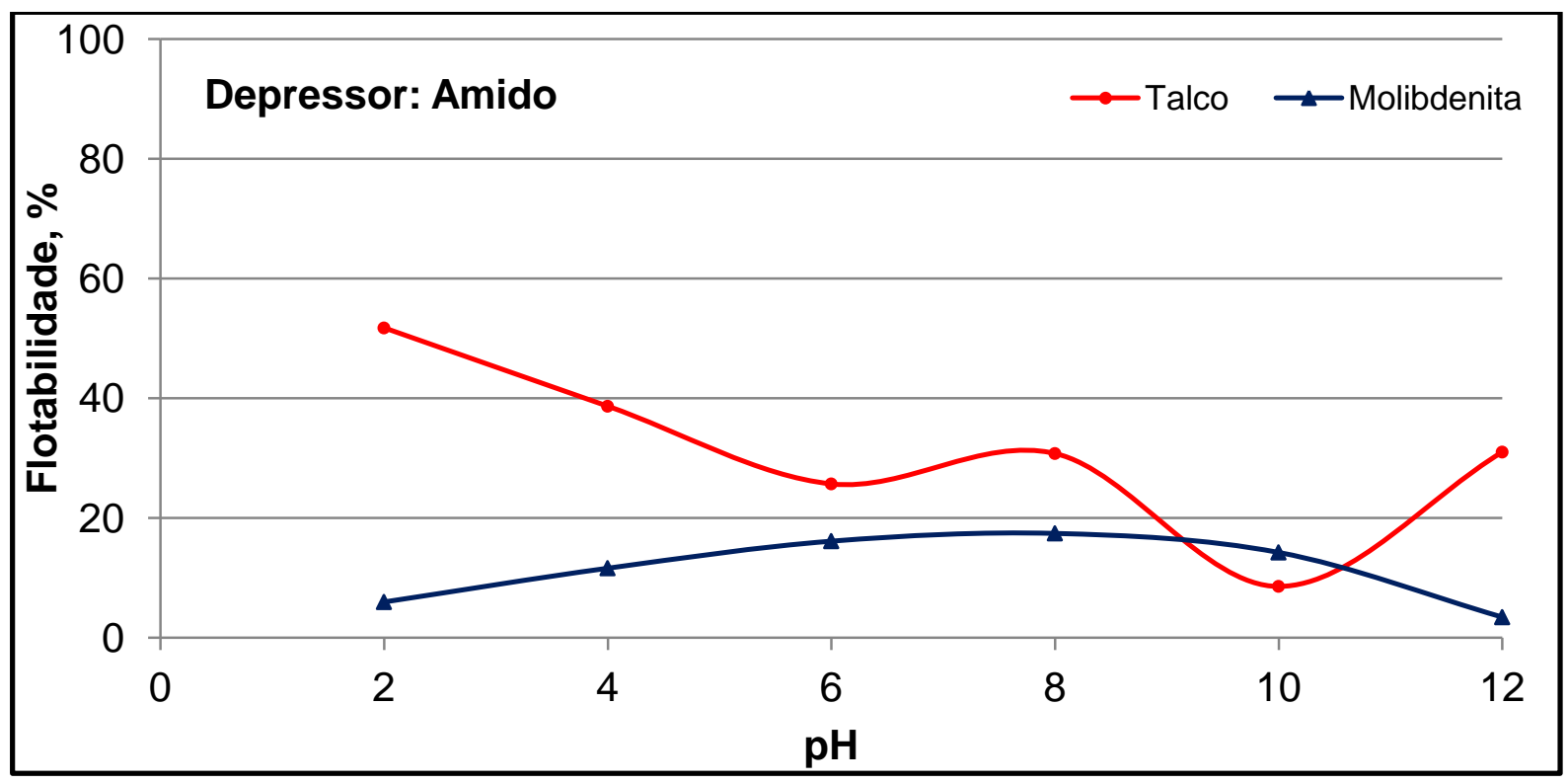

Figura 6.21 - Influência do pH na flotabilidade da molibdenita e do talco na presença de amido

A Figura 6.22 mostra os resultados do teste de flotabilidade no qual se utilizou o ácido húmico, polímero aniônico, como agente depressor. Não foi verificada diferença (janela) entre as separabilidades dos minerais acima de $50 \%$. A molibdenita e o talco apresentaram valores de flotabilidade semelhantes no intervalo de $\mathrm{pH}$ entre 2 e 8. Para a molibdenita, o efeito depressor do ácido húmico é independente do $\mathrm{pH}$, em toda a faixa estudada e na concentração de 100 ppm. Para concentrações do ácido húmico menores que 5 ppm, o efeito depressor é bastante significativo na faixa alcalina de pH (LAI; STONE; RIMMASCH; 1984).

A curva de flotabilidade do talco mostra uma redução no efeito depressor do ácido húmico em valores de $\mathrm{pH}$ acima de 8. O ácido húmico possui duas constantes de equilíbrio (pK): a primeira, em $\mathrm{pH}$ 4, é resultante da protonação dos grupos carboxílicos e a segunda, em pH 8, que resulta da protonação dos grupos fenolatos. A dissociação desses grupos funcionais contribui para a formação de cargas aniônicas e consequente reatividade dos ácidos húmicos (GHABBOUR; DAVIES, 2001). Outra propriedade dos ácidos húmicos é a sua maior eletronegatividade a partir de valores de pH 7 (BRUM, 2005), corroborando com a sua constante de dissociação em torno de pH 8. Nessa situação tanto o ácido húmico quanto o talco apresentam elevada eletronegatividade (valores absolutos), o que possivelmente promove a dessorção (devido à repulsão) do ácido húmico da superfície do talco. 


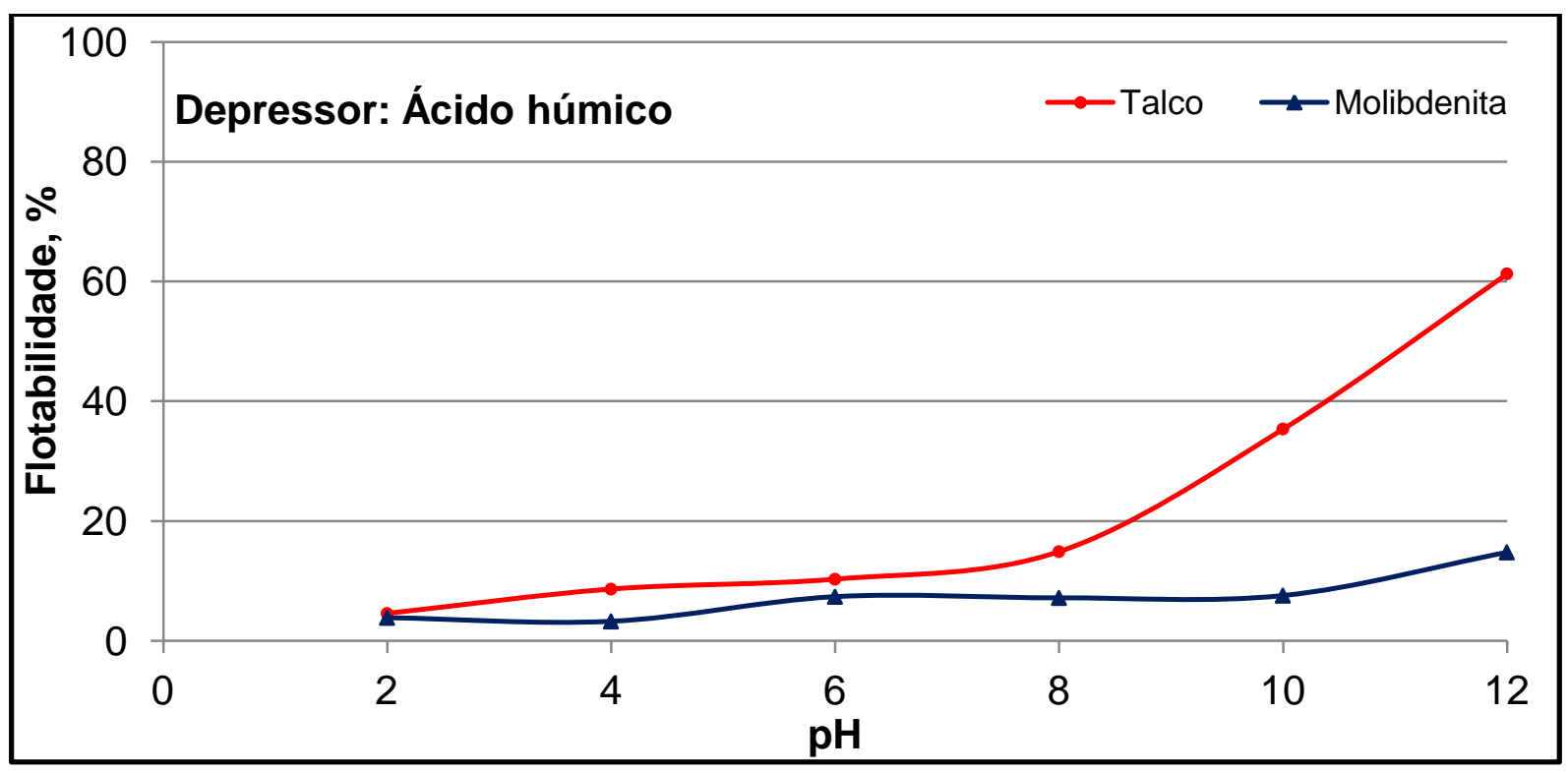

Figura 6.22 - Influência do pH na flotabilidade da molibdenita e do talco na presença de ácido húmico

A Figura 6.23 mostra os resultados do teste de flotabilidade no qual se utilizou o silicato de sódio como agente depressor inorgânico. Verifica-se que as curvas de flotabilidade têm aspecto muito semelhante ao apresentado na Figura 6.16, para flotabilidade sem agente depressor.

A dissociação do silicato de sódio, dada pela Equação 4.6, produz um ácido fraco e uma base forte.

$$
\mathrm{Na}_{2} \mathrm{SiO}_{3}+2 \mathrm{H}_{2} \mathrm{O} \Leftrightarrow \mathrm{H}_{2} \mathrm{SiO}_{3}+2 \mathrm{Na}^{+}+2 \mathrm{OH}^{-}
$$

Essa propriedade do silicato de sódio promove o aumento no efeito depressor sobre a molibdenita e, consequentemente, a redução na flotabilidade do mineral a partir de valores de $\mathrm{pH}$ acima de 6 . Como comentado anteriormente no item 6.2.4, a redução na flotabilidade é devida à presença de cargas elétricas contidas nas bordas ou microbordas das faces da molibdenita, originadas da oxidação e hidrólise do $\mathrm{MoO}_{3}$ a $\mathrm{HMoO}_{4}{ }^{-}$e $\mathrm{MoO}_{4}{ }^{2-}$ (Equação 6.2).

Verifica-se que a variação do $\mathrm{pH}$ não exerce nenhum efeito depressor do silicato de sódio sobre a superfície do talco. 


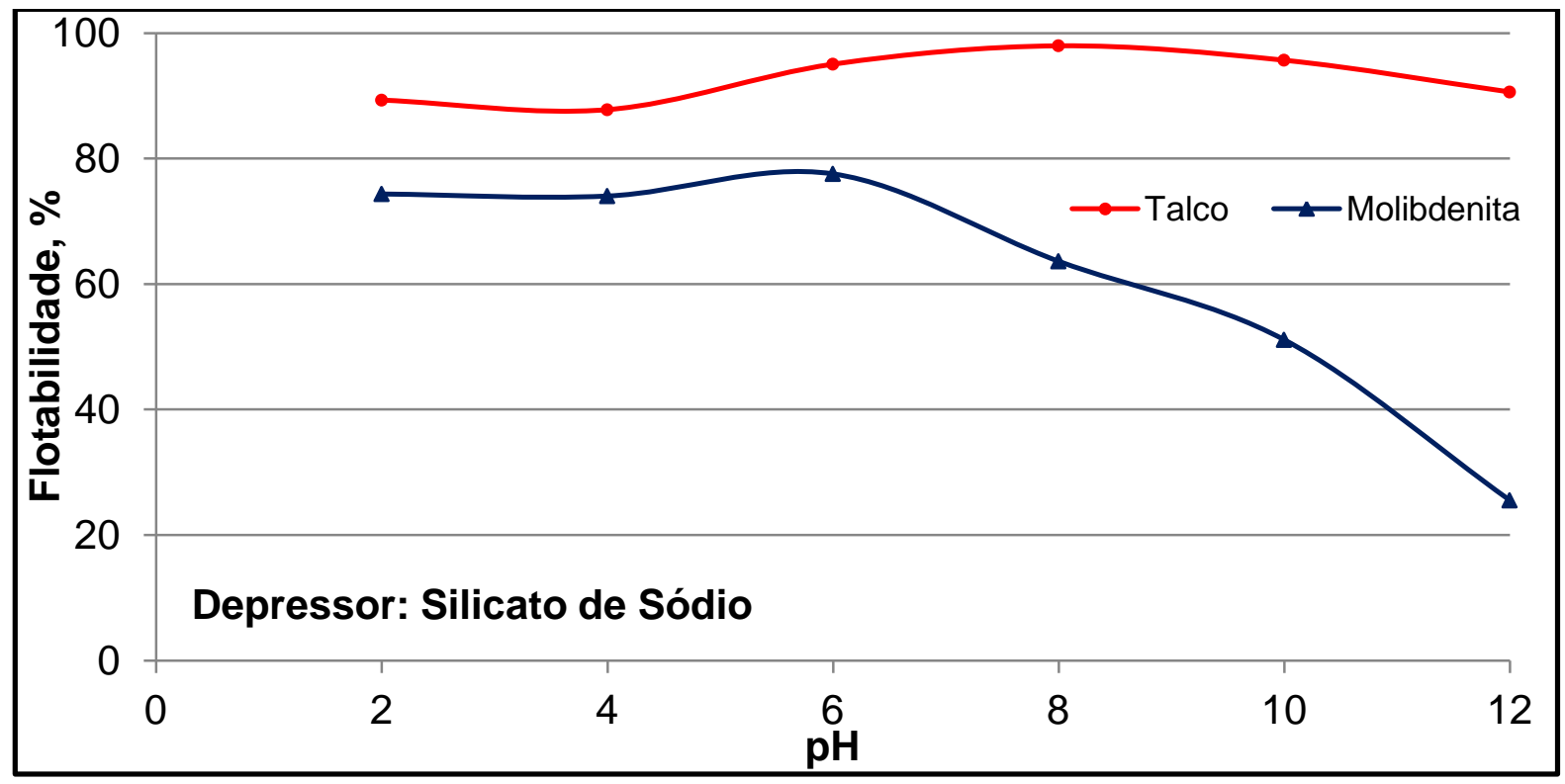

Figura 6.23 - Influência do pH na flotabilidade da molibdenita e do talco na presença de silicato de sódio

A Figura 6.24 mostra os resultados do teste de flotabilidade no qual se utilizou a dextrina, polímero não iônico, como depressor. Verifica-se tanto na curva de flotabilidade da molibdenita quanto na do talco uma independência total do $\mathrm{pH}$. De modo geral, em toda extensão de $\mathrm{pH}$ existe uma janela de separação considerável, evidenciando a eficiência da dextrina como depressor da molibdenita, na concentração da solução de 100 ppm.

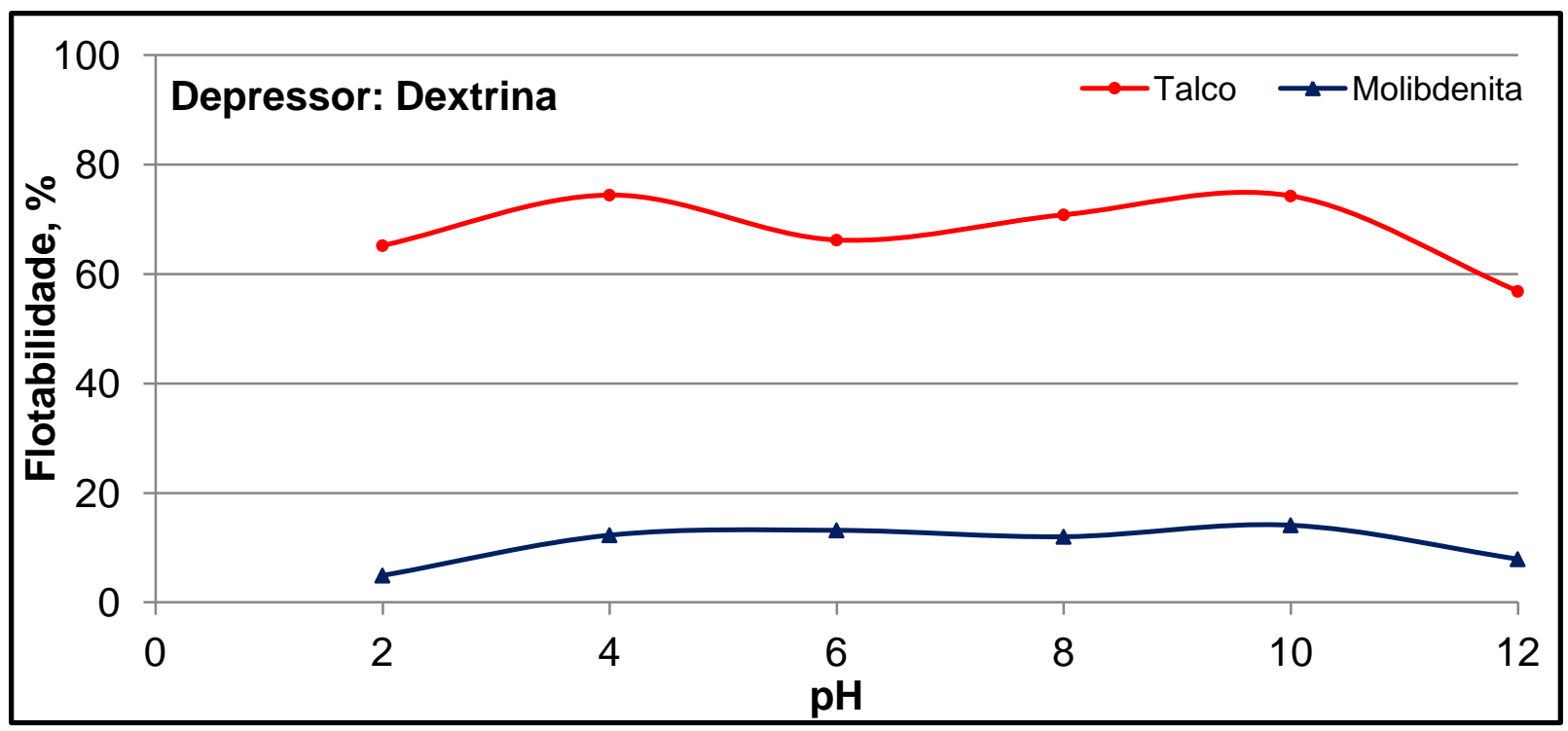

Figura 6.24 - Influência do $\mathrm{pH}$ na flotabilidade da molibdenita e do talco na presença de dextrina

Conforme observado na Figura 6.24 foram obtidas janelas de separabilidade acima de $50 \%$ em quase todo o intervalo de $\mathrm{pH}$ avaliado. Resultados semelhantes 
de flotabilidade do talco foram obtidos por Liu et al. (2006), utilizando como agentes depressores a dextrina,carboximetil celulose (CMC) e carboximetil amido (CMS).

Apesar da adsorção de polissacarídeos não iônicos, como a dextrina, na superfície do talco ser independente do $\mathrm{pH}$, a redução observada na curva de flotabilidade do talco (Figura 6.24) em valores de $\mathrm{pH}$ mais elevados pode ser explicada pela maior repulsão das bolhas de ar, provavelmente ocasionada pela dissolução de partículas. As espécies hidrolizadas adsorvidas contribuem para o aumento da hidrofilicidade, conforme relatado por Fuerstenau e Huang (2003).

Os resultados obtidos motivaram a realização de uma nova série de ensaios com objetivo de verificar a influência da concentração da solução do depressor, dextrina, na flotabilidade da molibdenita e do talco. Esses ensaios foram realizados em $\mathrm{pH}$ 8, por estar próximo da neutralidade.

As curvas contidas na Figura 6.25 ilustram a flotabilidade dos minerais molibdenita e talco em pH 8 e em diferentes concentrações de dextrina $(10,25,50$, 100 e 200 ppm).

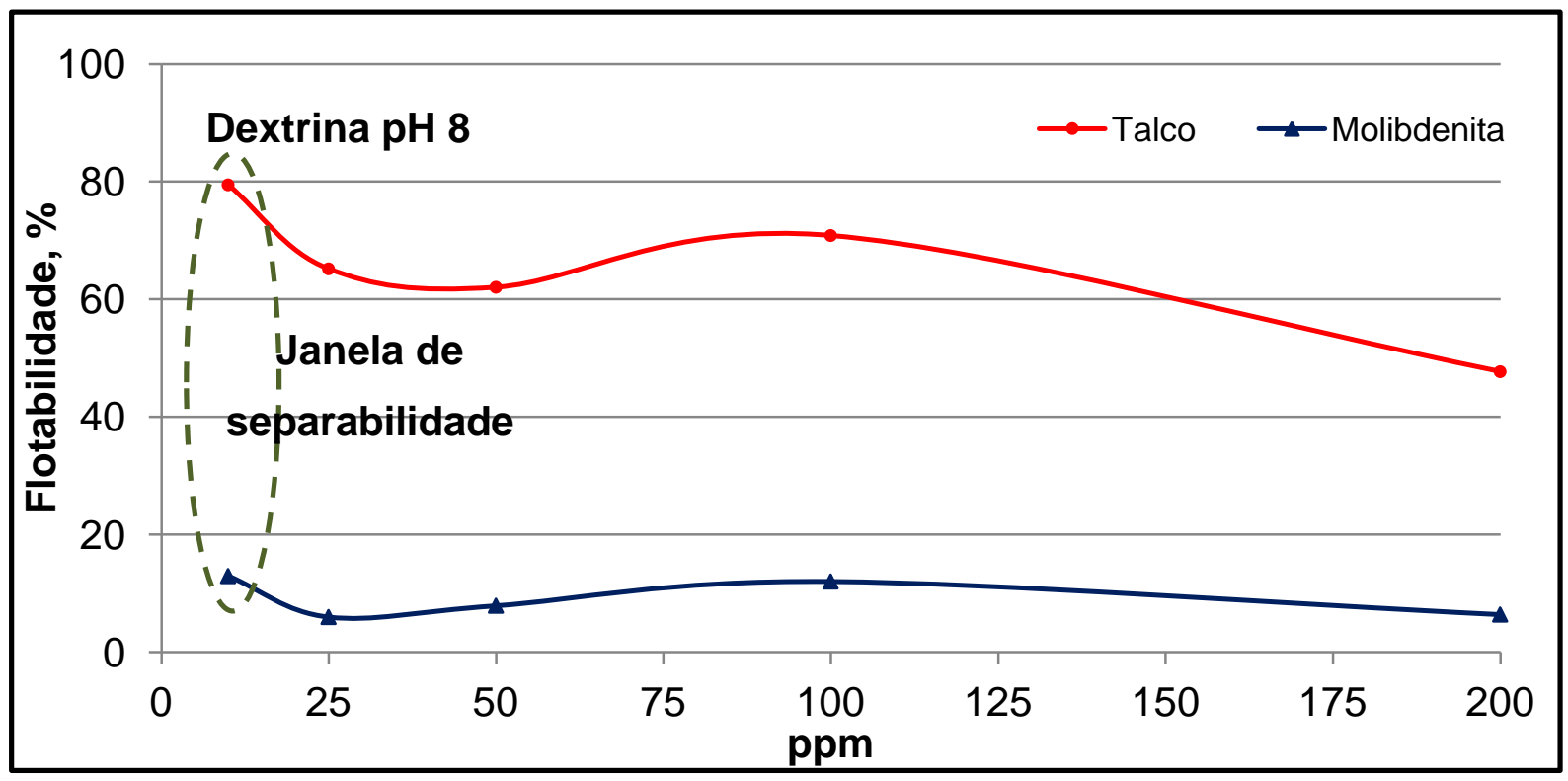

Figura 6.25 - Flotabilidade da molibdenita e do talco em diferentes concentrações de dextrina e $\mathrm{pH} 8$

Foi obtida uma janela com $68 \%$ de separabilidade, utilizando-se a dextrina na concentração de 10 ppm. A atuação mais eficiente da dextrina como depressor da molibdenita observada neste trabalho se deve, possivelmente, à melhor adsorção desse polímero na superfície por meio de interações hidrofóbicas. 
Beattie et al. (2006) realizaram estudo sobre a flotabilidade do talco na presença de dextrina como agente depressor e os resultados mostraram uma recuperação do talco de 87,70 e 67\%, para as concentrações de dextrina de 25, 50 e 75 ppm, respectivamente, em pH 8,7, natural da suspensão estudada. Resultados semelhantes foram obtidos, como apresentado na Figura 6.25. Na concentração de 10 ppm e pH 8, é possível recuperar $80 \%$ do talco e apenas $12 \%$ da molibdenita.

As curvas de potencial zeta para a molibdenita pura e tratada com dextrina (Figura 6.27) mostram que as superfícies são eletronegativas em quase toda a extensão de $\mathrm{pH}$, com pontos isoelétricos localizados em $\mathrm{pH}$ menor que 2. Também está claro que a partir de $\mathrm{pH} 6$ existe um aumento mais acentuado na eletronegatividade da superfície da molibdenita, que se deve, possivelmente, à oxidação e hidrólise do $\mathrm{MoO}_{3}$ a $\mathrm{HMoO}_{4}{ }^{-}$e $\mathrm{MoO}_{4}{ }^{2-}$, tornando a superfície mais eletronegativa.

Embora a dextrina seja um polímero não iônico, sem possíveis interações eletrostáticas com a superfície da molibdenita, verificou-se claramente na Figura 6.26 que a sua adsorção na superfície da molibdenita afetou o potencial zeta, promovendo um deslocamento da curva para a região de menor eletronegatividade. Wie e Fusternau (1974) postularam que essa redução na eletronegatividade seja devida ao possível deslocamento do plano de Stern durante a medida do potencial zeta. Também é sugerido que a adsorção da dextrina na molibdenita deva-se a ligações hidrofóbicas, o que também é reportado por Laskowski et al. (2007), em trabalho sobre o entendimento dos mecanismos de adsorção de polissacarídeos em superfícies minerais. Nesse mesmo trabalho, Laskowski e colaboradores postularam que o mecanismo de adsorção da dextrina também envolve a formação de complexos entre os grupos $-\mathrm{OH}$ e os sítios metálicos da superfície mineral. 


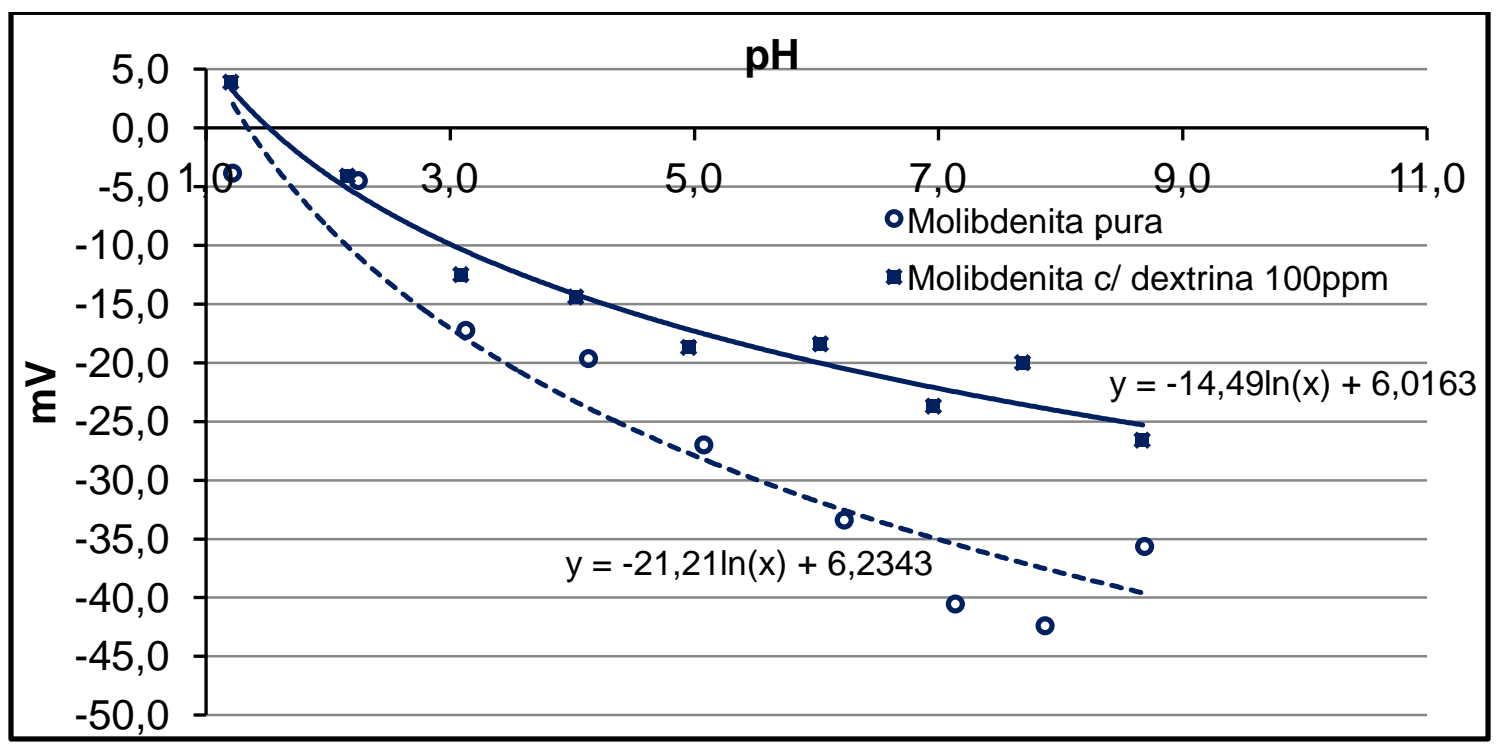

Figura 6.26 - Curva de potencial zeta da molibdenita com e sem dextrina

As curvas de potencial zeta para o talco puro e tratado com dextrina (Figura 6.27) mostram que as superfícies são eletronegativas em quase toda a extensão de $\mathrm{pH}$, com pontos isoelétricos localizados em $\mathrm{pH}$ menor que 2. Verifica-se que a presença da dextrina teve pouca influência sobre o potencial zeta do talco; promovendo apenas um pequeno aumento na sua eletronegatividade.

Os resultados apresentados na Figura 6.27 estão de acordo com os obtidos por Liu et al. (2001), em estudo sobre potencial zeta em amostra de talco natural e modificadas por lixiviação e calcinação.

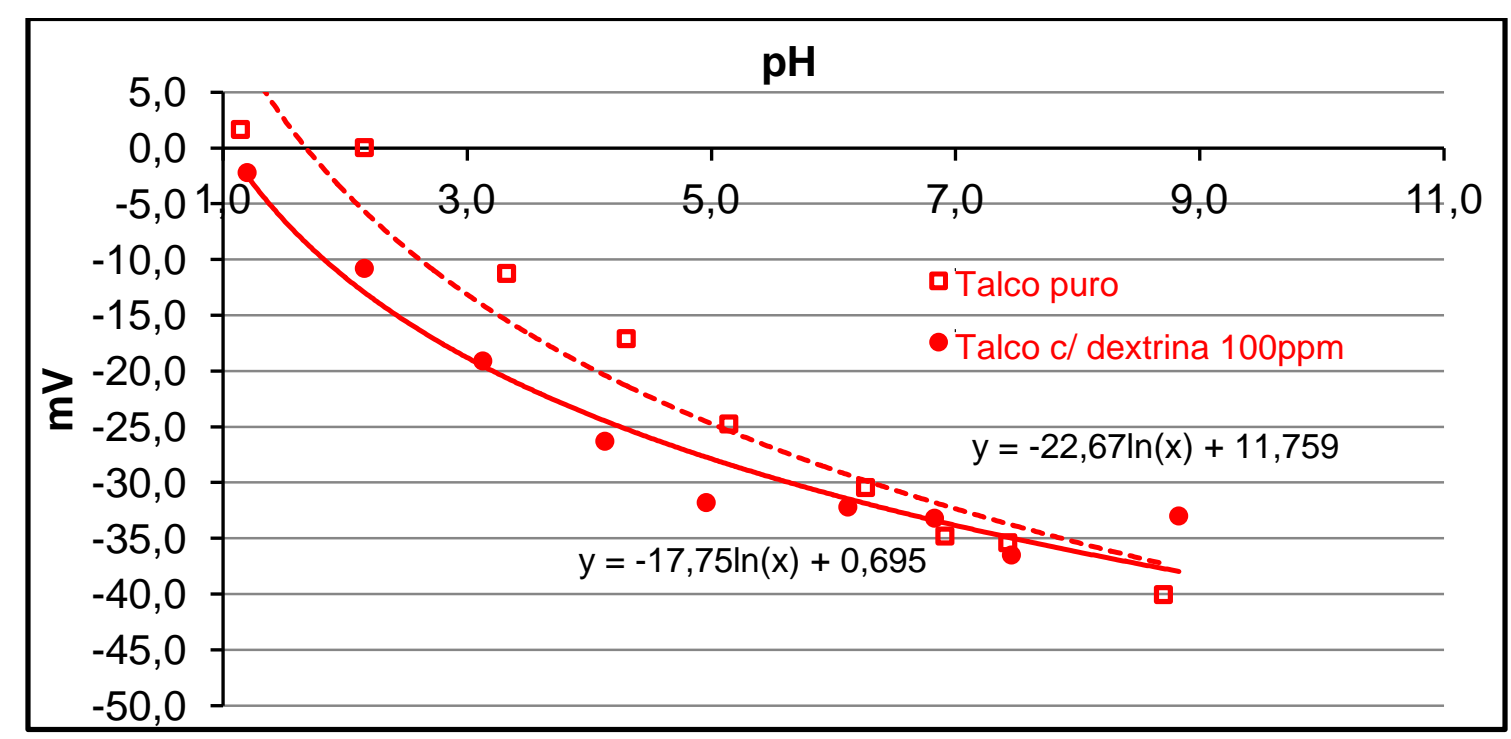

Figura 6.27 - Curva de potencial zeta do talco com e sem dextrina

A Figura 6.28 mostra os resultados do teste de flotabilidade no qual se utilizou o quebracho, polímero não iônico, como agente depressor. Verifica-se pouca 
sinergia entre a flotabilidade da molibdenita e o pH do meio. De modo geral, em toda extensão de $\mathrm{pH}$ existe boa depressão da molibdenita, evidenciando a eficiência do quebracho como agente depressor.

Apesar da adsorção de polímeros orgânicos, como o quebracho, ser independente do $\mathrm{pH}$, a ação do quebracho sobre o talco foi menos efetiva no intervalo de $\mathrm{pH}$ compreendido entre 6 e 8, abrindo-se uma janela de separabilidade considerável em pH 8.

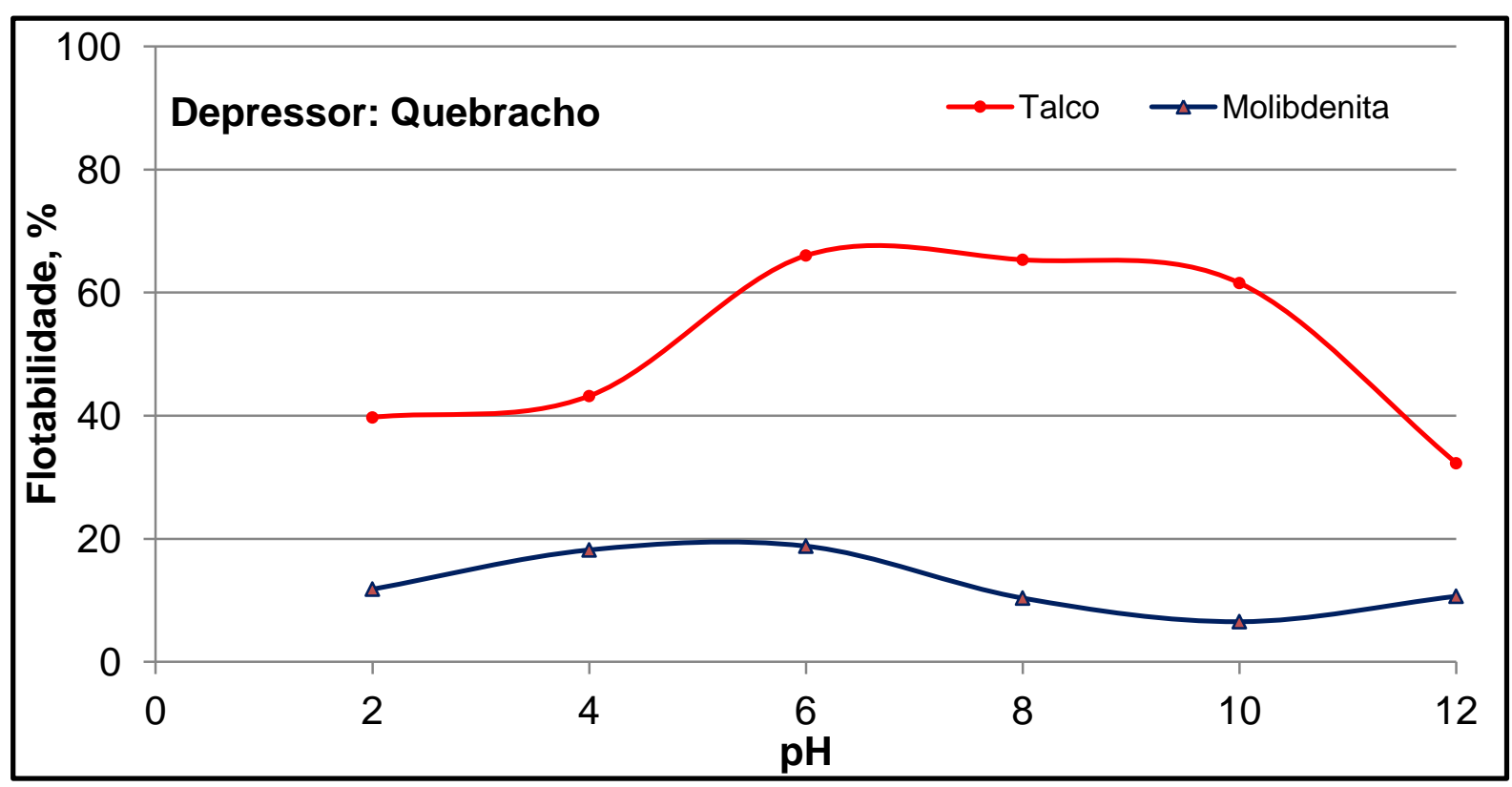

Figura 6.28 - Influência do pH na flotabilidade da molibdenita e do talco na presença de quebracho

A janela de separabilidade, utilizando-se quebracho como depressor em $\mathrm{pH} 8$, motivou a realização de uma nova série de ensaios com o objetivo de verificar a influência da concentração da solução desse depressor na flotabilidade da molibdenita e do talco. Esses ensaios foram realizados em $\mathrm{pH} 8$, onde uma boa janela de separação foi proporcionada, provavelmente devido à maior solubilidade do quebracho neste pH (PEARSE, 2005).

As curvas contidas na Figura 6.29 apresentam os resultados da flotabilidade dos minerais molibdenita e talco em pH 8 e diferentes concentrações de quebracho (10, 25, 50, 100 e 200 ppm). 


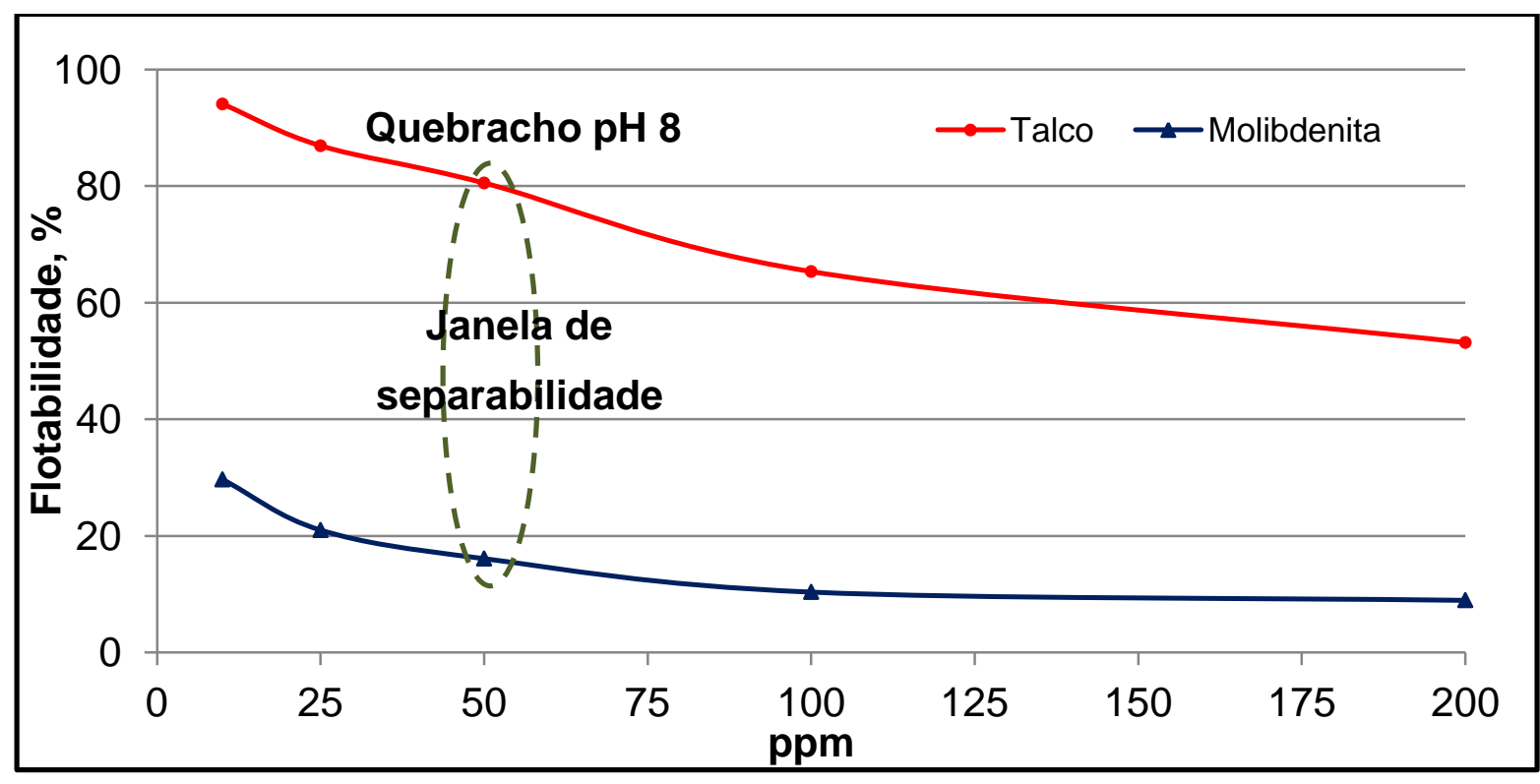

Figura 6.29 - Flotabilidade da molibdenita e do talco em diferentes concentrações de quebracho a $\mathrm{pH} 8$

Foi obtida uma janela com 63\% de separabilidade (Figura 6.29), utilizando-se o quebracho na concentração de 50 ppm. A atuação eficiente do quebracho como depressor da molibdenita, observada na Figura 6.29 se deve, possivelmente, à melhor adsorção desse polímero na superfície do mineral, por meio de interações hidrofóbicas, mecanismo preferencial de atuação dos polissacarídeos em minerais naturalmente hidrofóbicos.

A determinação do potencial zeta teve por objetivo verificar a influência do $\mathrm{pH}$ sobre as cargas elétricas na superfície da molibdenita e do talco, na presença e ausência de quebracho, como agente depressor.

As curvas de potencial zeta para a molibdenita pura e tratada com quebracho (Figura 6.30) mostram que as superfícies estão eletronegativas em praticamente toda a extensão de pH, com pontos isoelétricos localizados em pH menor que 2. Também está claro que a partir de $\mathrm{pH} 6$ existe um aumento mais acentuado na eletronegatividade da superfície da molibdenita, que se deve, provavelmente, à oxidação e hidrólise do $\mathrm{MoO}_{3}$ a $\mathrm{HMoO}_{4}{ }^{-}$e $\mathrm{MoO}_{4}{ }^{2-}$, tornando a superfície mais eletronegativa.

No trabalho realizado por Ciribeni et al (2002) sobre o efeito depressor do quebracho na flotação de sulfetos, o mecanismo de adsorção era atribuído ao resultado da união por pontes de hidrogênio entre átomos de oxigênio e enxofre; à formação de complexos entre os grupos hidroxilas dos fenóis com cátions metálicos di e trivalentes; à neutralização de cargas em meio alcalino sobre a superfície 
carregada positivamente; ou à atração eletrostática entre as micelas de taninos carregadas negativamente e a superfície mineral.

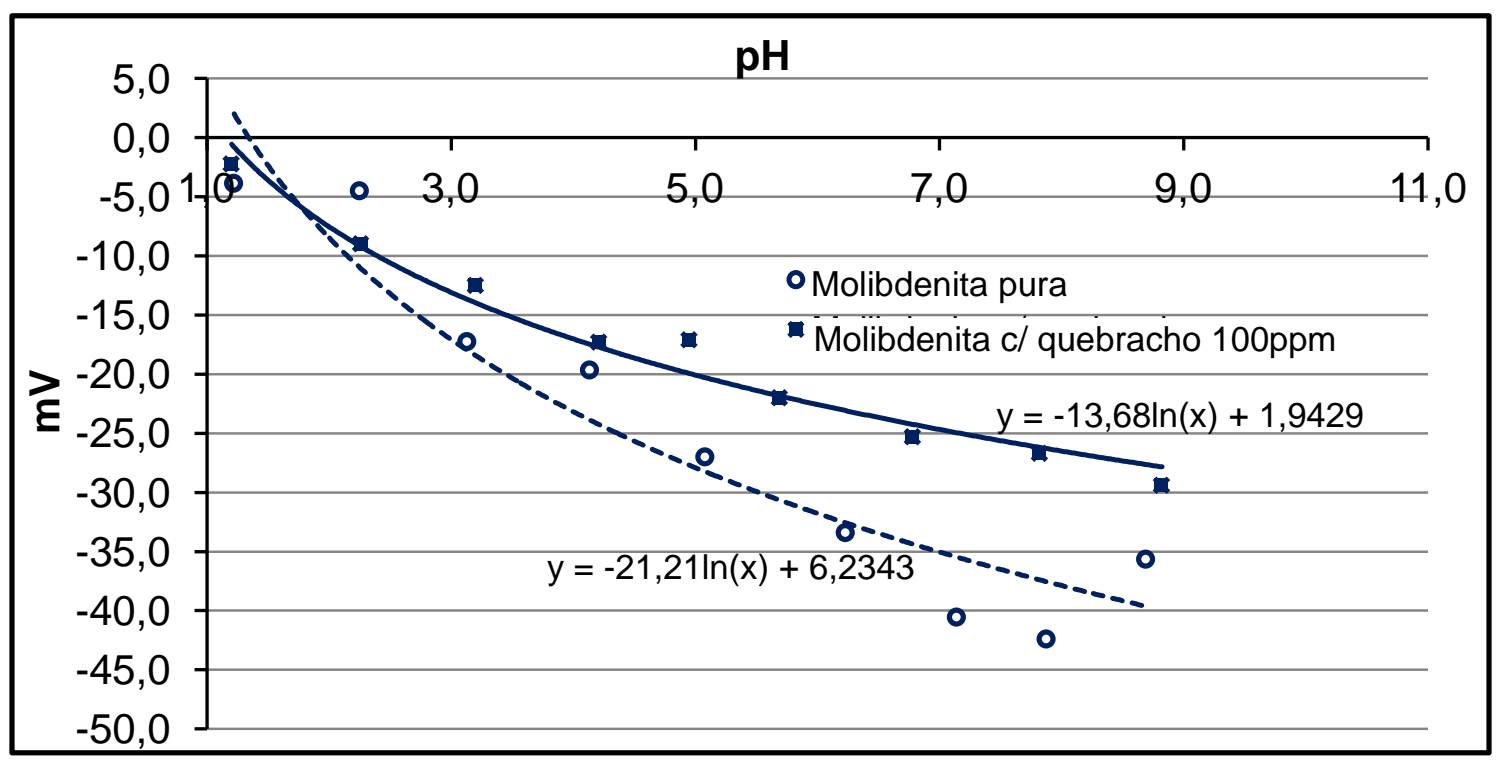

Figura 6.30 - Curva de potencial zeta da molibdenita com e sem quebracho

A medida de potencial zeta realizada para o mineral talco na presença e ausência de quebracho, contida na Figura 6.31, mostra claramente que a adsorção na superfície do talco afetou o potencial, promovendo um deslocamento da curva para a região de maior eletronegatividade. Esse deslocamento foi de magnitude constante em toda extensão de $\mathrm{pH}$, inclusive em relação ao ponto isoelétrico.

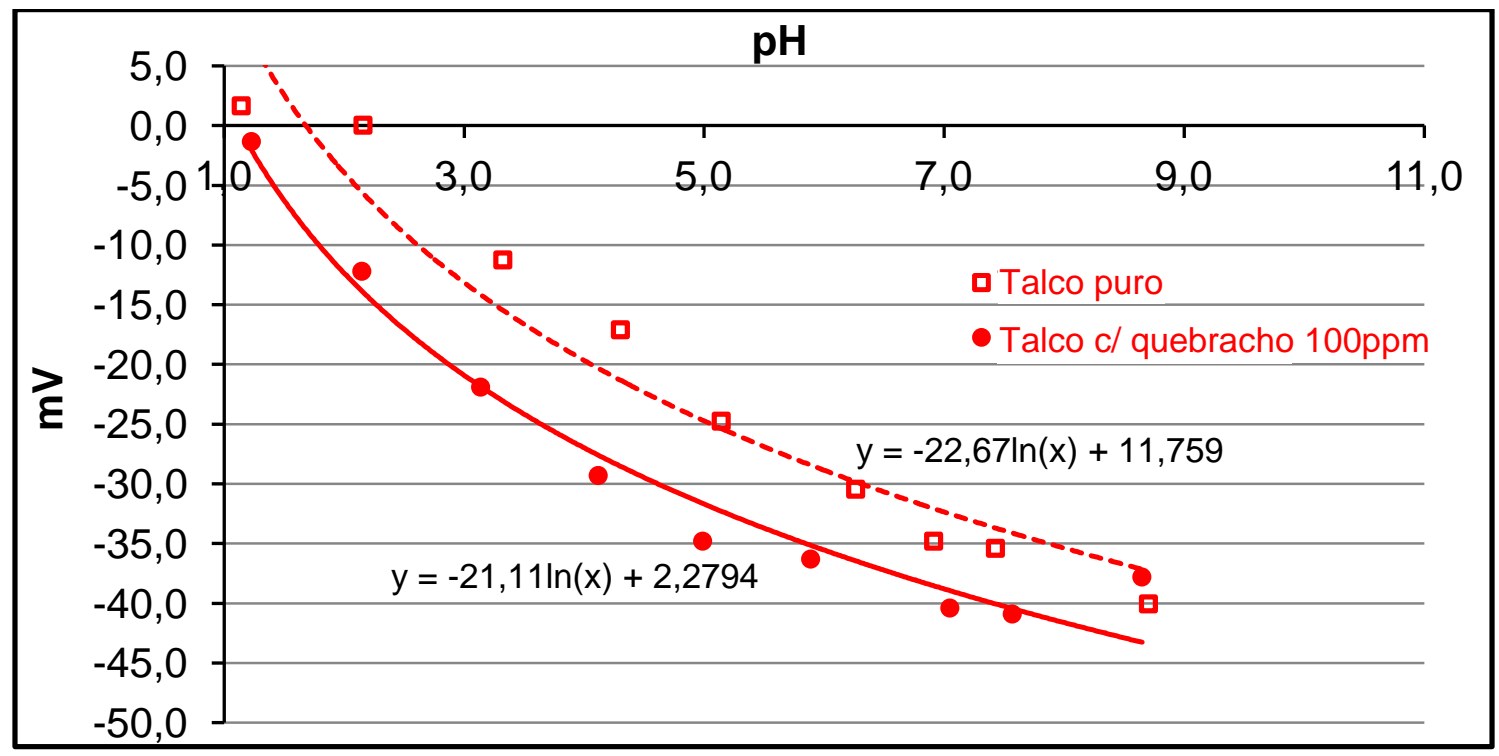

Figura 6.31 - Curva de potencial zeta do talco com e sem quebracho

Poucos trabalhos são reportados na literatura sobre os usos e efeitos do quebracho como reagente na indústria mineral, talvez por se tratar de um produto 
natural, obtido do cerne de árvores (schinopsis quebracho colorado) predominantes no continente sul americano, formado por países com recursos financeiros limitados na área de ciência e tecnologia e tradicionalmente importadores de produtos trademark. Honrosa exceção à regra é o uso de amidos, modificados ou não, na flotação do quartzo no beneficiamento de minérios de ferro nacionais.

\subsubsection{Medida do Ângulo de Contato pelo Método de Ascensão Capilar}

O ângulo de contato formado entre a superfície dos minerais (molibdenita e talco) e um solvente polar e apolar (água e hexana, respectivamente) foi medido pelo método de ascensão capilar no tensiômetro Krüss K100. Seu cálculo é função da inclinação da reta obtida pelo quadrado da massa em função do tempo para um líquido polar e um líquido apolar, conforme definido na Equação 5.2 (Equação de Washburn modificada).

A hexana é um líquido apolar que molha os minerais naturalmente hidrofóbicos como a molibdenita e o talco; ao contrário, a água é um líquido polar com baixa afinidade por estes minerais. O ângulo de contato previsto para minerais naturalmente hidrofóbicos como a molibdenita e o talco em líquido apolar, como a hexana, que molha perfeitamente esses minerais, é $0^{\circ}$ e $90^{\circ}$ para líquido polar, como a água, que não molha esses minerais.

A Tabela 6.7 mostra os resultados das medidas do ângulo de contato da molibdenita e do talco puros (sem tratamento com depressor), medido no tensiômetro Krüss K100 e a constante de capilaridade (c) medida em hexana.

Tabela 6.7 - Ângulo de contato e constante de capilaridade dos minerais molibdenita e talco puros

\begin{tabular}{ccc}
\hline Minerais & Ângulo de contato $(\theta)$ & Constante de capilaridade \\
\hline Molibdenita & $89,2^{\circ}$ & $1,06 \times 10^{-5}$ \\
Talco & $85,6^{\circ}$ & $1,03 \times 10^{-5}$ \\
\hline
\end{tabular}

Os resultados contidos na Tabela 6.7 validam o procedimento para a medida do ângulo de contato pelo método de ascensão capilar, baseado na equação modificada de Washburn (Equação 5.2) e estão de acordo com as medidas de ângulo de contato realizadas em goniômetro, pelo método da bolha cativa, para os minerais molibdenita e talco (FUERSTENAU; SOMASUNDARAN, 2003). Diferenças de resultados em relação ao ângulo de contato formado na interface mineral/água/ar 
podem ocorrer, para esses minerais naturalmente hidrofóbicos, quando determinados por metodologias diferentes, a saber: no método da bolha cativa, essas medidas geralmente são realizadas no plano basal (faces) desses minerais, enquanto o método da ascensão capilar trata de um valor médio que considera tanto as faces hidrofóbicas quanto as bordas hidrofílicas, as quais são funções da granulometria do mineral.

As curvas mostradas nas Figuras 6.32 e 6.33 apresentam as medidas do ângulo de contato da molibdenita quando submetida ao condicionamento com dextrina e quebracho, em diferentes concentrações. Essas curvas mostram uma redução do ângulo de contato formado na interface mineral/água/ar pelo efeito depressor, tanto da dextrina quanto do quebracho, na superfície da molibdenita gerando uma redução na sua hidrofobicidade natural e, consequentemente, na sua flotabilidade.

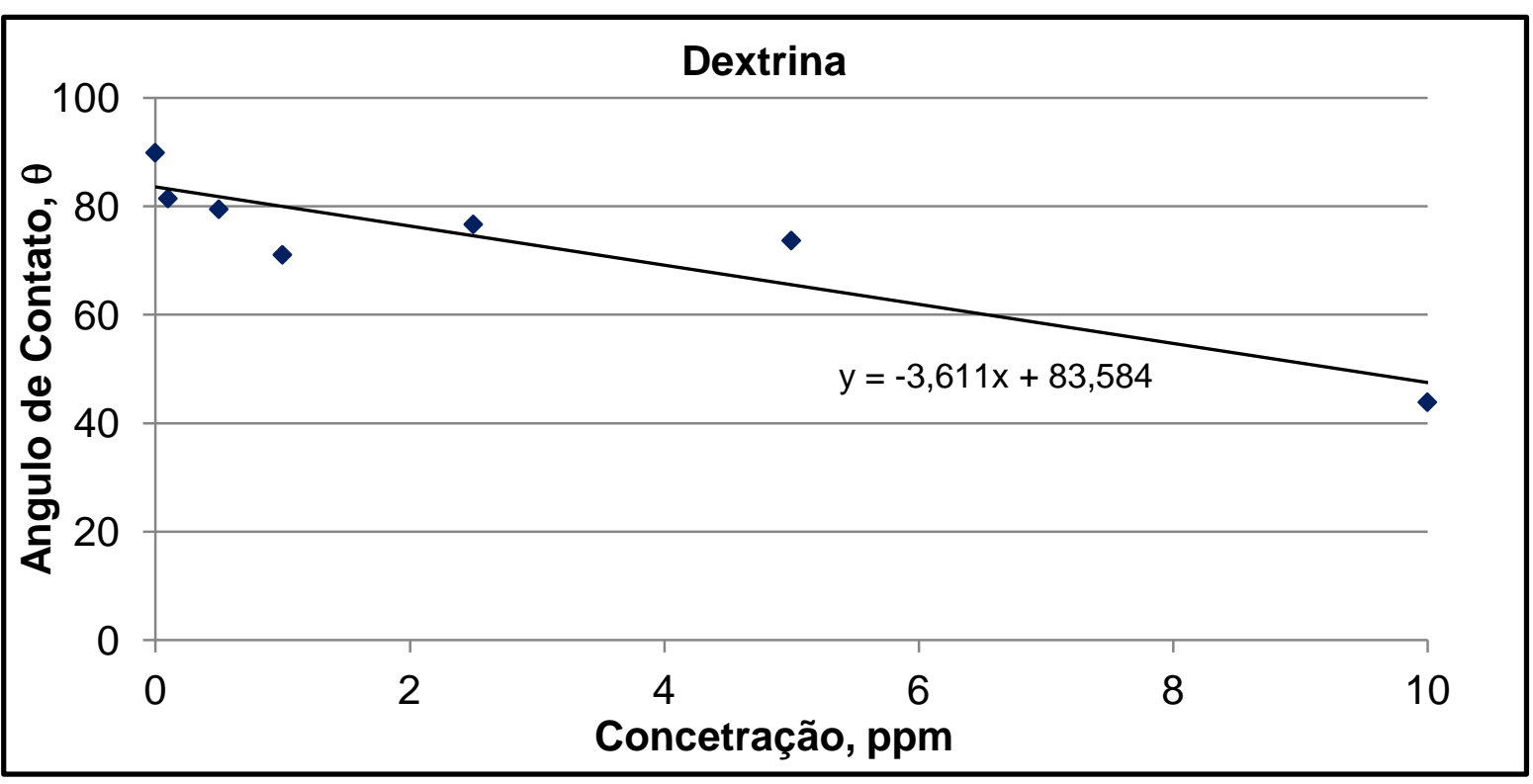

Figura 6.32 - Ângulos de contato da molibdenita condicionada em diferentes concentrações de dextrina. 


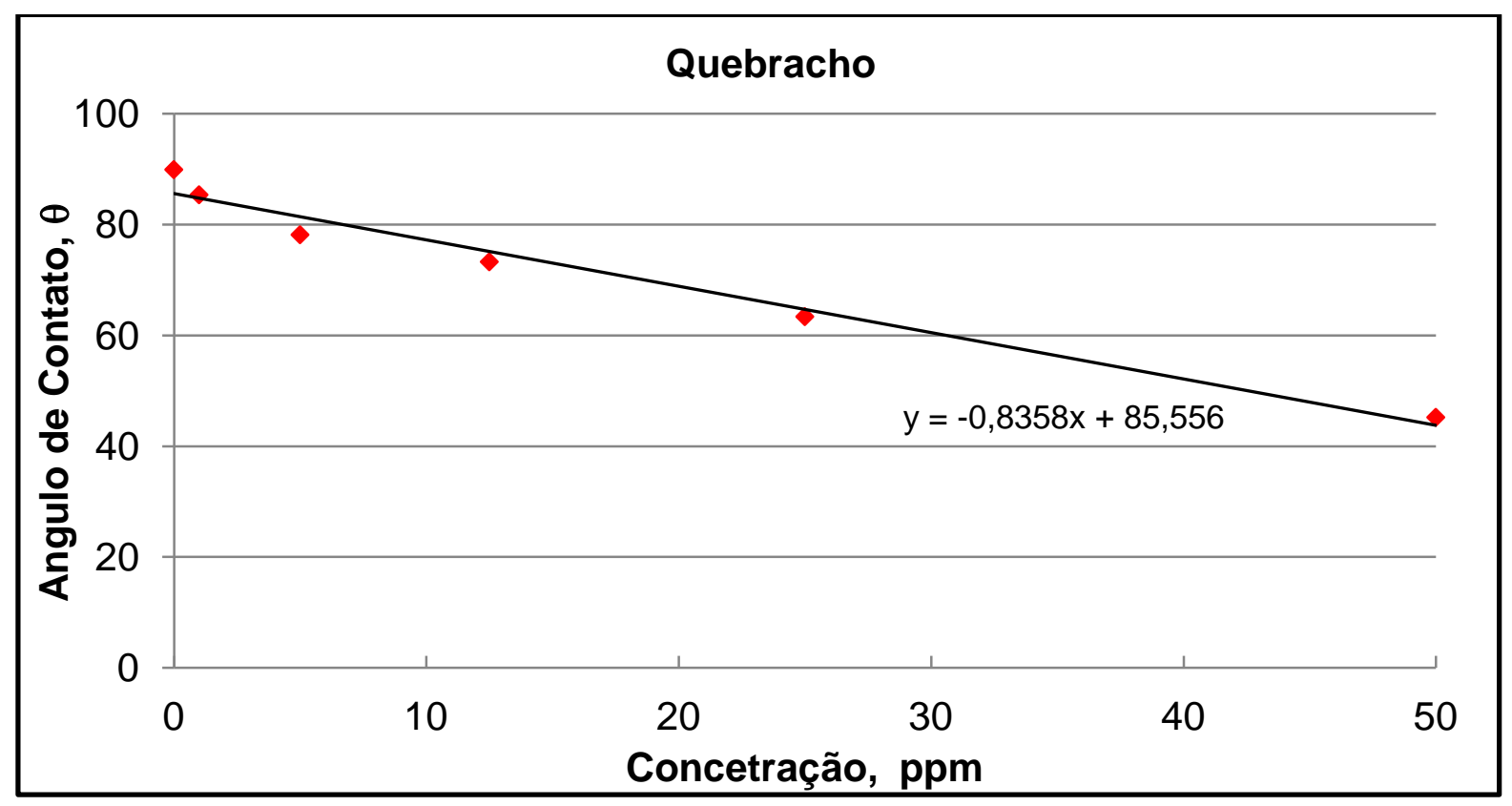

Figura 6.33 - Ângulos de contato da molibdenita condicionada em diferentes concentrações de quebracho

No talco, o ângulo de contato formado na interface mineral/água/ar, não sofreu nenhuma alteração significativa quando submetido ao condicionamento com dextrina ou quebracho, mantendo o seu valor original medido sem tratamento (substância pura), isto é, com $\theta$ igual a 85,6․

Esses resultados da medida de ângulo de contato pelo método de ascensão capilar corroboram com os resultados dos ensaios de flotabilidade na presença dos depressores dextrina e quebracho, proporcionando uma janela de separabilidade dos minerais molibdenita e talco (Figuras 6.25 e 6.29), ambos naturalmente hidrofóbicos e modificados pela ação do agente depressor.

Chau (2009) fez uma revisão sobre a aplicação de diferentes técnicas de medida de ângulos de contato em superfícies minerais. $O$ autor reporta a dificuldade que existe em se obter uma superfície mineral homogênea, que atenda aos requisitos do método da bolha cativa, e conclui que o método da ascensão capilar é o mais adequado para a medida de ângulos de contato em amostras minerais reais, por considerar a heterogeneidade da amostra.

\subsubsection{Medida do Peso Molecular da Dextrina e do Quebracho}

Minerais de flotabilidade natural, como talco e molibdenita, são deprimidos em processos industriais mediante o uso de polímeros orgânicos hidrofílicos, os quais são adsorvidos na superfície dos minerais hidrofóbicos por meio de ligações 
hidrofóbicas. Essa adsorção promove um aumento efetivo nas ligações por pontes de hidrogênio com as moléculas de água próximas à interface; com isso, inibindo a adesão das bolhas de ar.

Com objetivo de conhecer o peso molecular dos polímeros depressores (dextrina e quebracho) que propiciaram uma janela de separabilidade molibdenita/talco por flotação, foram realizadas medidas das soluções dos polímeros no equipamento Zetasizer Nano ZS utilizando a técnica Static Light Scattering (SLC). A representação gráfica das Figuras 6.34 e 6.35, conhecida como Debye Plot, mostra os resultados dos pesos moleculares determinados, que é equivalente ao inverso do coeficiente linear da reta gerada $\left(\mathrm{KC} / \mathrm{R}_{\theta}=1 / M_{w}\right)$.

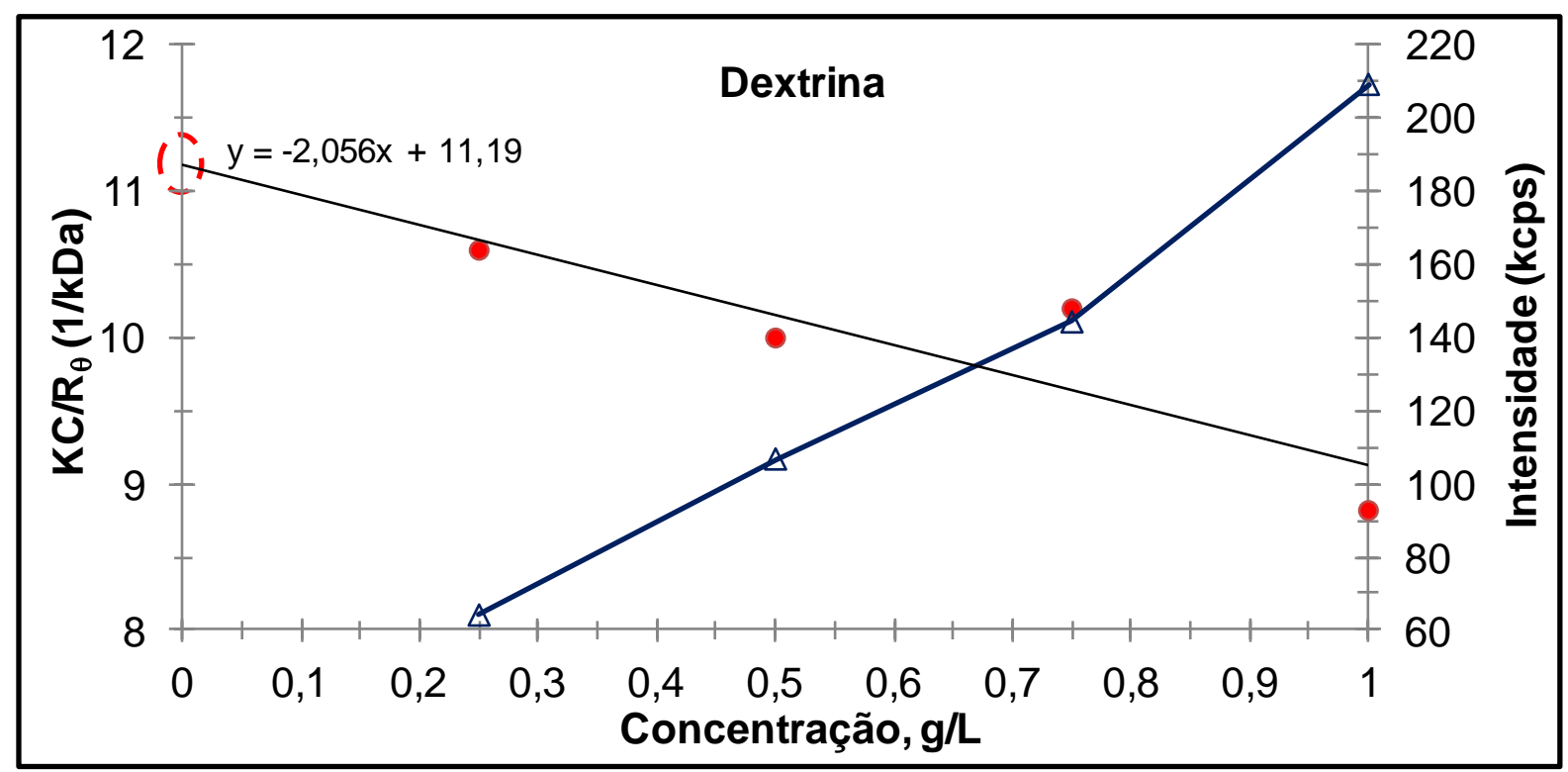

Figura 6.34 - Determinação do peso molecular da dextrina

O peso molecular determinado para a amostra de dextrina (Sigma-Aldrich ${ }^{\circledR}$ ) utilizada nos ensaios de flotabilidade para a separação molibdenita/talco foi da ordem de $8.900 \mathrm{Da}$. Resultados semelhantes estão contidos no trabalho de Beattie et al. (2006) para dois tipos diferentes de dextrina (WY e HP), com valores de 9.260 e 14.500 Da, respectivamente.

A dextrina é geralmente produzida a partir de amido de milho, por ação da decomposição térmica e química (hidrólise ácida) ou por ação enzimática. Esse processo de decomposição do amido é conhecido como dextrinização, no qual as cadeias do amido são quebradas, produzindo cadeias monoméricas menores, porém mantendo a mesma proporção entre amilopectina e amilose da molécula original. A 
dextrina resultante tem peso molecular que pode variar de 800 a $79.000 \mathrm{Da}$ (BALTAR, 2010; MONTE; PERES, 2010).

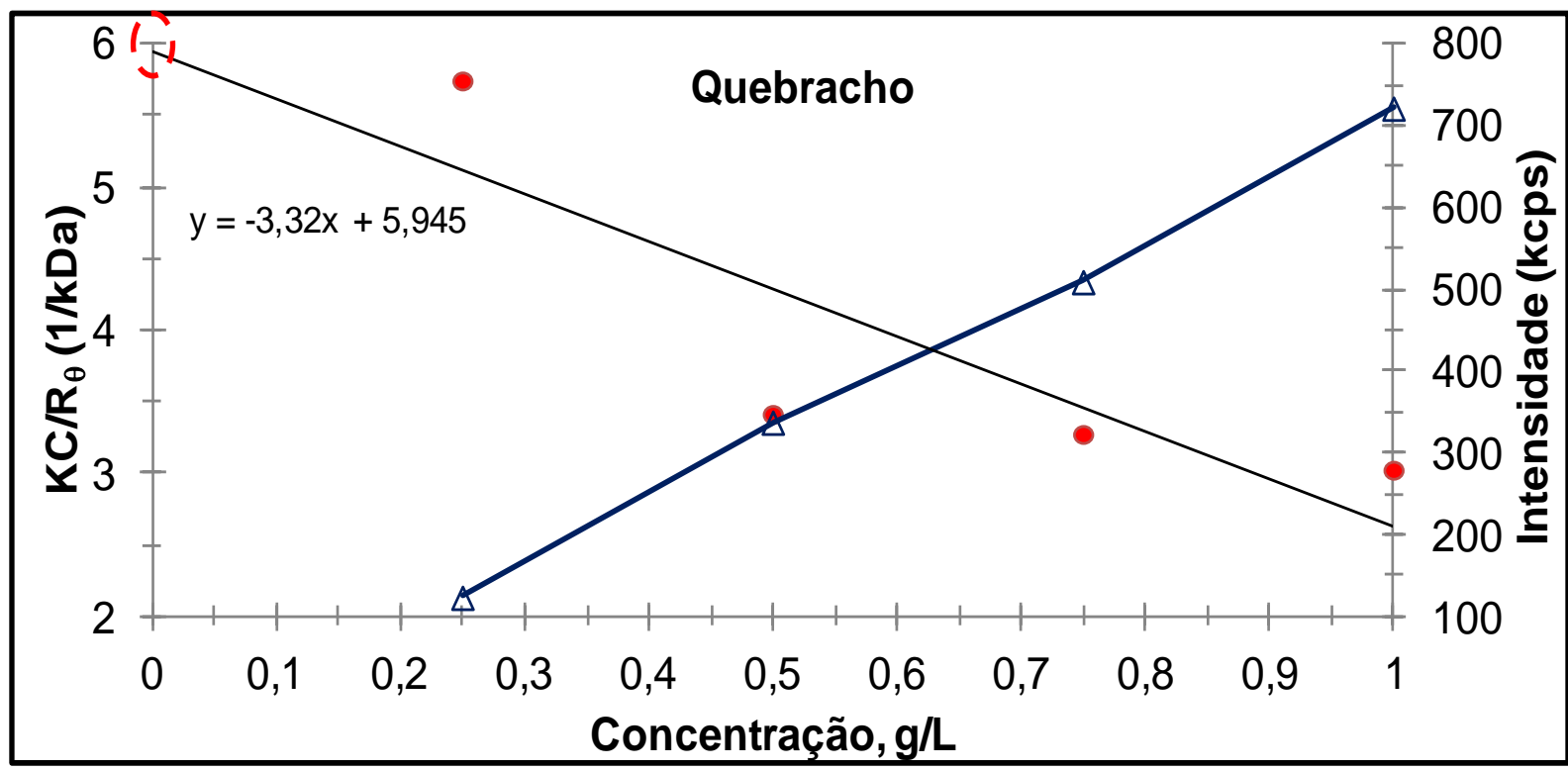

Figura 6.35 - Determinação do peso molecular do quebracho

O peso molecular determinado para a amostra de quebracho (Floatan M3) utilizado nos ensaios de flotabilidade para a separação molibdenita/talco foi da ordem de $16.800 \mathrm{Da}$.

Pantoja-Castro e Gonzalez-Rodriguez (2011) determinaram o peso molecular do quebracho (Schinopsis quebracho colorado) por cromatografia gasosa, encontrando um valor de $6.485 \mathrm{Da}$. O peso molecular da espécie original de tanino de quebracho é variável e constituído por monômeros $(1<\mathrm{n}<200)$, inferindo em pesos moleculares na faixa de 200 a 50.000 Da. Para melhorar a seletividade, os fabricantes de quebracho realizam processamento químico e físico com o objetivo de promover seletividades específicas para cada aplicação do produto (UNITAN, 2012).

Com base nos resultados de flotabilidade apresentados no item 6.2.5, verificou-se uma pequena diferença nas janelas de flotabilidade, com maior eficiência para o sistema utilizando a dextrina. Lin e Burdick (2009) reportam que polímeros de menor peso molecular oferecem como vantagem a maior quantidade de moléculas por unidade de peso, permitindo melhor homogeneização na polpa mineral. 


\subsection{PURIFICAÇÃO DO CONCENTRADO DE MOLIBDENITA EM BANCADA}

\subsubsection{Caracterização do concentrado de molibdenita}

Para realização dos ensaios de purificação da molibdenita por flotação em bancada foi utilizado um concentrado mineral de baixo teor produzido na região de Campo Formoso, BA. A distribuição granulométrica deste concentrado foi determinada em peneiras da série Tyler e está apresentada na Figura 6.36. O concentrado mineral tem amplo intervalo de distribuição granulométrica, com diâmetro médio das partículas em $67 \mu \mathrm{m}$ e $33 \%$ de finos $(-37 \mu \mathrm{m})$.

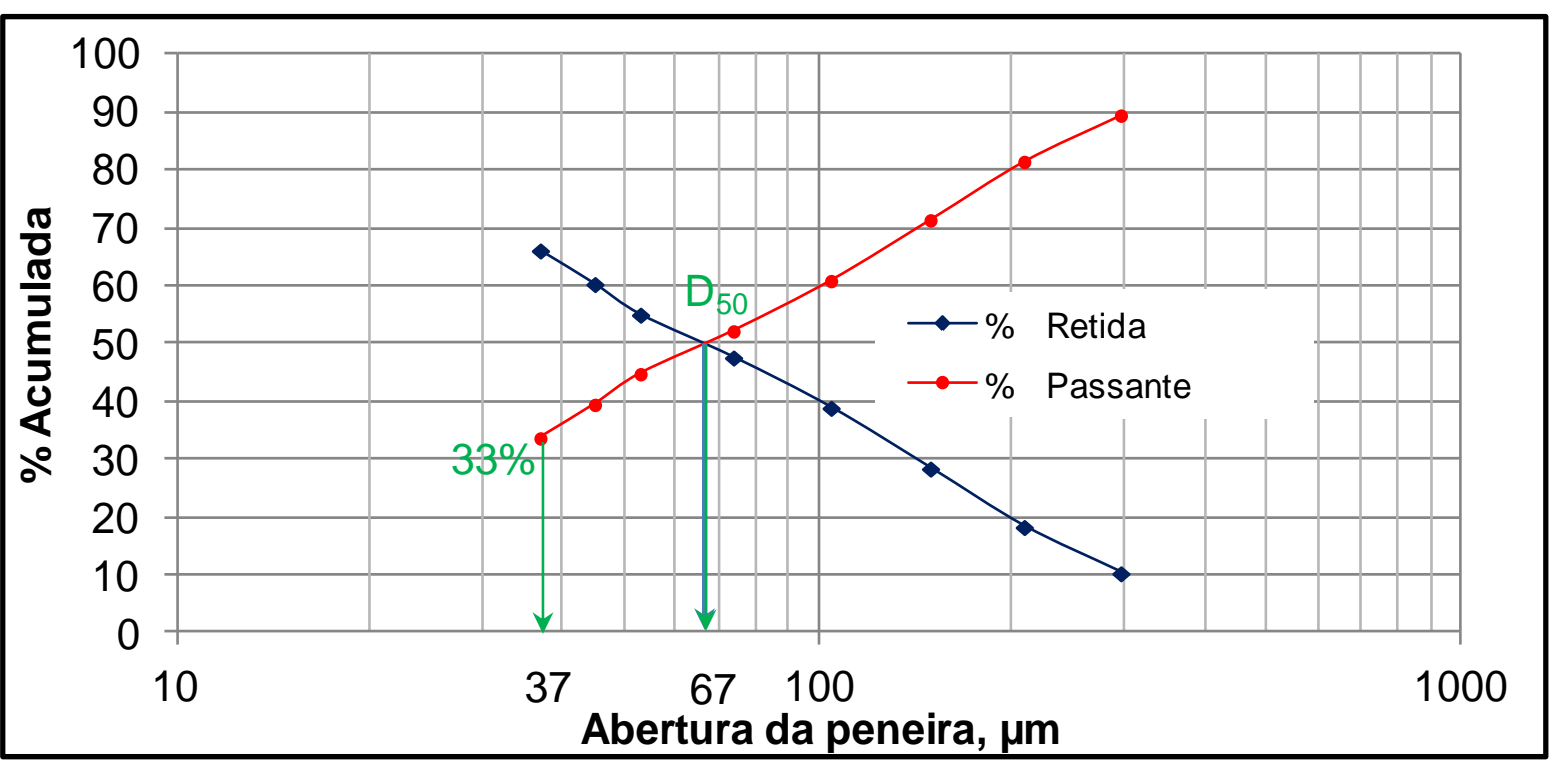

Figura 6.36 - Distribuição granulométrica do concentrado de molibdenita

A análise química do concentrado de molibdenita utilizado nos testes de bancada está contida na Tabela 6.8. Os principais minerais presentes no concentrado (identificados em lupa binocular), além da molibdenita, foram o talco, a flogopita e o clinocloro.

Tabela 6.8 - Análise química do concentrado de molibdenita (alimentação da flotação)

\begin{tabular}{cccccccccc}
\hline $\mathrm{Na}_{2} \mathrm{O}$ & $\mathrm{MgO}$ & $\mathrm{Al}_{2} \mathrm{O}_{3}$ & $\mathrm{SiO}_{2}$ & $\mathrm{~K}_{2} \mathrm{O}$ & $\mathrm{CaO}$ & $\mathrm{Fe}_{2} \mathrm{O}_{3}$ & $\mathbf{M o S}_{2}$ & $\mathrm{Bi}_{2} \mathrm{O}_{3}$ & Total \\
\hline 0,15 & 4,15 & 3,25 & 10,95 & 2,40 & 0,47 & 2,75 & $\mathbf{7 5 , 1 0}$ & 0,56 & 99,78 \\
\hline
\end{tabular}




\subsubsection{Purificação do concentrado por flotação}

O concentrado de molibdenita utilizado nos ensaios de flotação em bancada (Figura 6.37) continha $75,10 \% \mathrm{MoS}_{2}$, equivalente a $44 \%$ de $\mathrm{Mo}$, e $4,15 \%$ de $\mathrm{MgO}$, indicativo da presença de talco (Tabela 6.8).

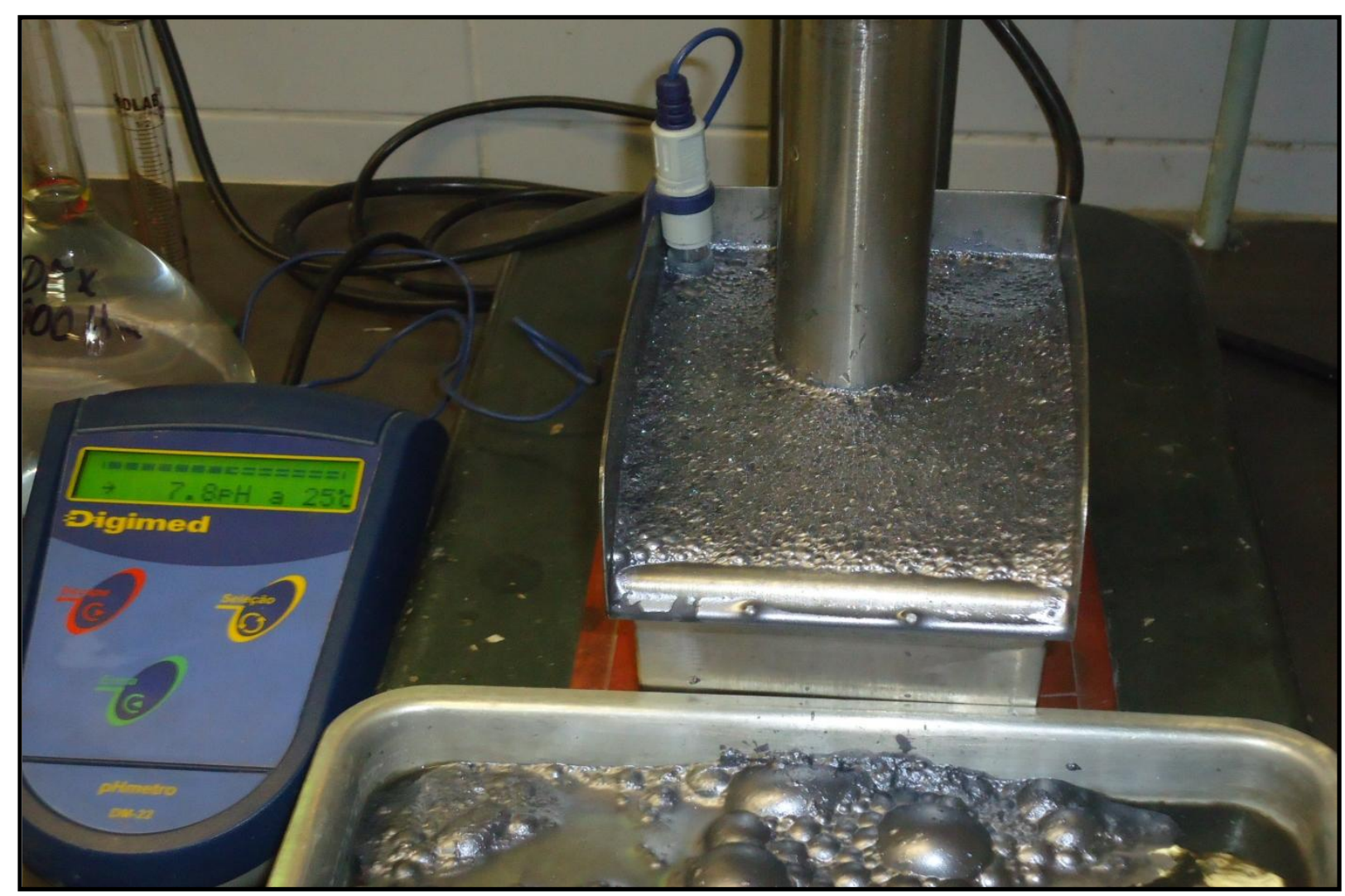

Figura 6.37 - Flotação em bancada, célula Denver D12

Os resultados dos ensaios de flotação reversa realizados para purificar o concentrado de molibdenita de baixo teor $\left(75,10 \% \mathrm{MoS}_{2}\right)$ estão apresentados nas Figuras 6.38 e 6.39 . Verifica-se na Figura 6.38 que os ajustes na dosagem da dextrina e o aumento no número de etapas cleaner, promoveram o enriquecimento gradativo do concentrado final de molibdenita. Na dosagem de $100 \mathrm{~g} / \mathrm{t}$ de dextrina e com a utilização de 5 (cinco) etapas cleaner foi possível obter concentrado de molibdenita com $93,4 \%$ de $\mathrm{MoS}_{2}$. 


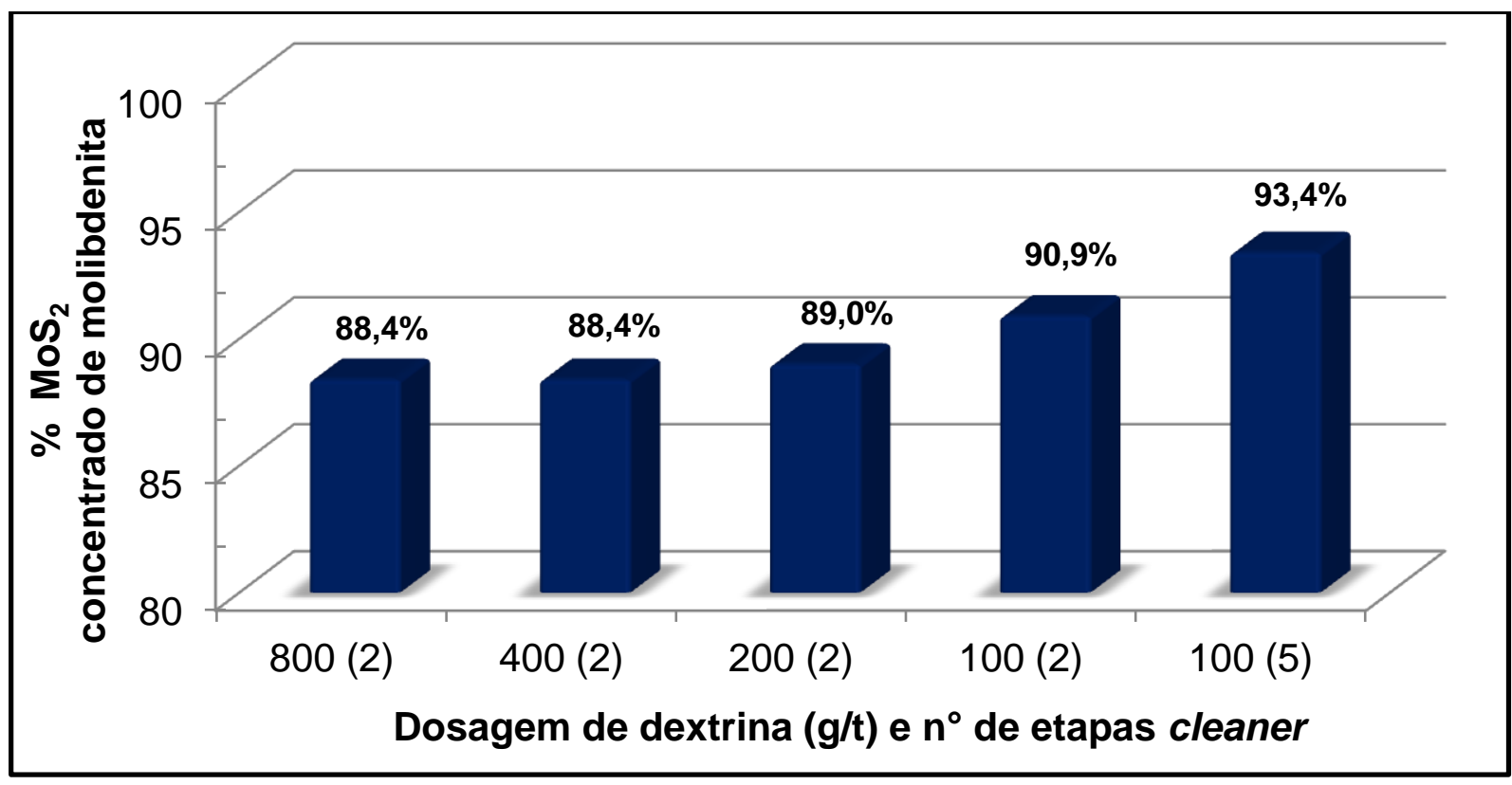

Figura 6.38 - Teor do concentrado final de molibdenita com diferentes dosagens de dextrina

A Figura 6.39 mostra a redução significativa do teor dos principais elementos contaminantes $\left(\mathrm{SiO}_{2}, \mathrm{MgO}, \mathrm{Al}_{2} \mathrm{O}_{3}\right.$ e $\left.\mathrm{K}_{2} \mathrm{O}\right)$ face à remoção de minerais naturalmente hidrofóbicos como o talco, a flogopita e o clinocloro.

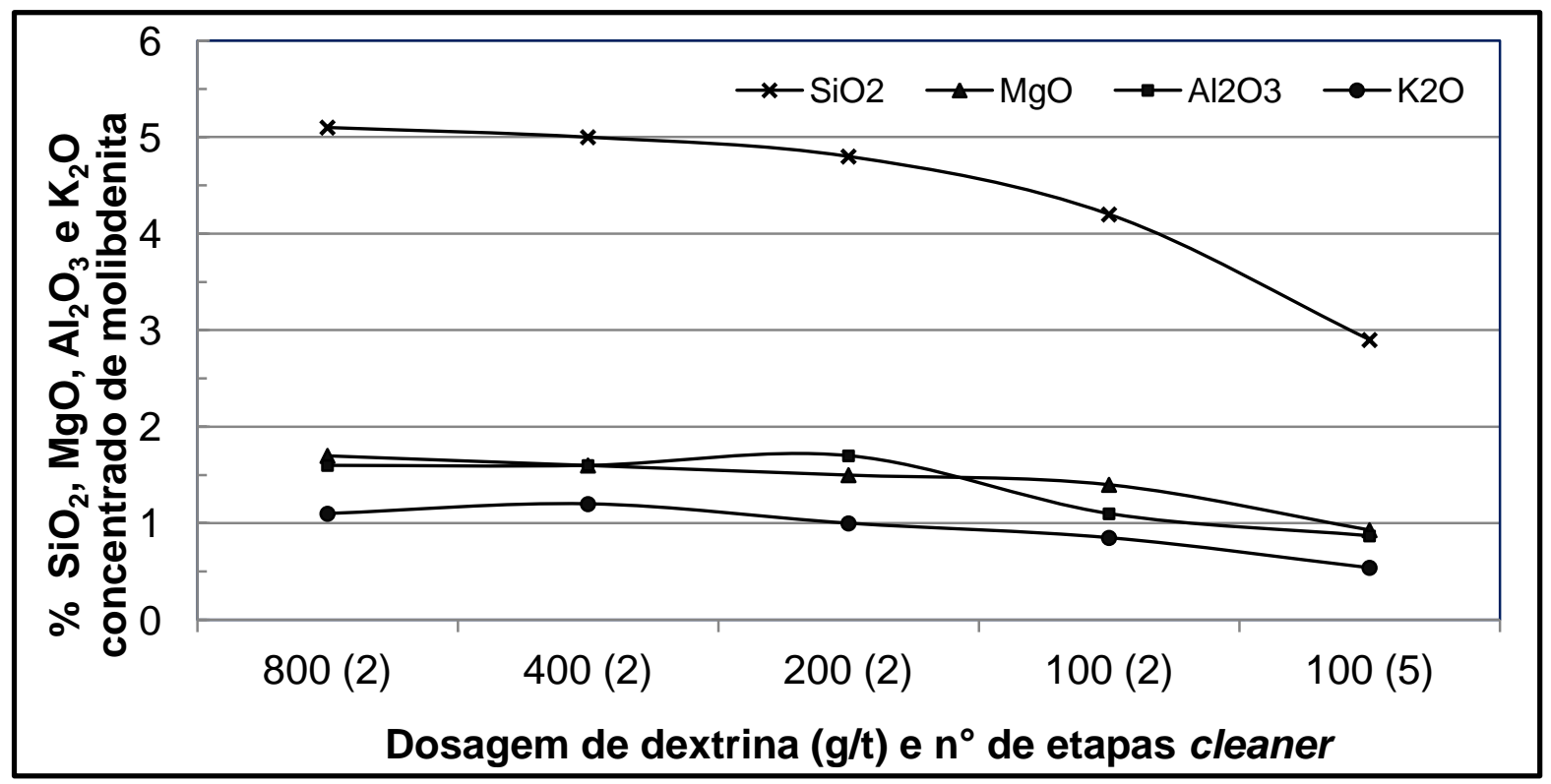

Figura 6.39 - Teor dos principais contaminantes nos concentrados de molibdenita com diferentes dosagens de dextrina

A análise química do concentrado de molibdenita purificado por flotação reversa, com a utilização de dextrina como depressor na dosagem de 100g/t e após 5 (cinco) etapas de limpeza está contida na Tabela 6.9. 
Tabela 6.9 - Análise química do concentrado de molibdenita purificado por flotação

\begin{tabular}{cccccccccc}
\hline $\mathrm{Na}_{2} \mathrm{O}$ & $\mathrm{MgO}$ & $\mathrm{Al}_{2} \mathrm{O}_{3}$ & $\mathrm{SiO}_{2}$ & $\mathrm{~K}_{2} \mathrm{O}$ & $\mathrm{CaO}$ & $\mathrm{Fe}_{2} \mathrm{O}_{3}$ & $\mathbf{M o S}_{2}$ & $\mathrm{Bi}_{2} \mathrm{O}_{3}$ & Total \\
\hline nd & 0,93 & 0,87 & 2,9 & 0,54 & 0,17 & 0,74 & $\mathbf{9 3 , 4}$ & 0,33 & 99,88 \\
\hline
\end{tabular}

O concentrado final $\left(93,4 \%\right.$ de $\left.\mathrm{MoS}_{2}\right)$ obtido com uso de dextrina como depressor da molibdenita na dosagem de $100 \mathrm{~g} / \mathrm{t}$ encontra-se dentro dos requisitos exigidos pelo comércio internacional (Tabela 4.5). A recuperação metalúrgica global do processo de flotação foi de $95 \%$.

\subsubsection{Purificação do concentrado de molibdenita por lixiviação fluorídrica}

O gráfico da Figura 6.40 mostra o resultado do teste de lixiviação fluorídrica para extração de contaminantes do concentrado de baixo teor de molibdenita. Verifica-se que a cinética de dissolução dos minerais contaminantes é acentuada nos primeiros 30 minutos de reação. Após 4 horas de lixiviação foi produzido um bissulfeto de molibdênio $\left(\mathrm{MoS}_{2}\right)$ com $92,9 \%$ de pureza. No entanto, o bissulfeto de molibdênio obtido não pode ser considerado grau lubrificante, pois é necessária uma pureza mínima de $98 \% \mathrm{MoS}_{2}$, conforme apresentado anteriormente na Tabela 4.6.

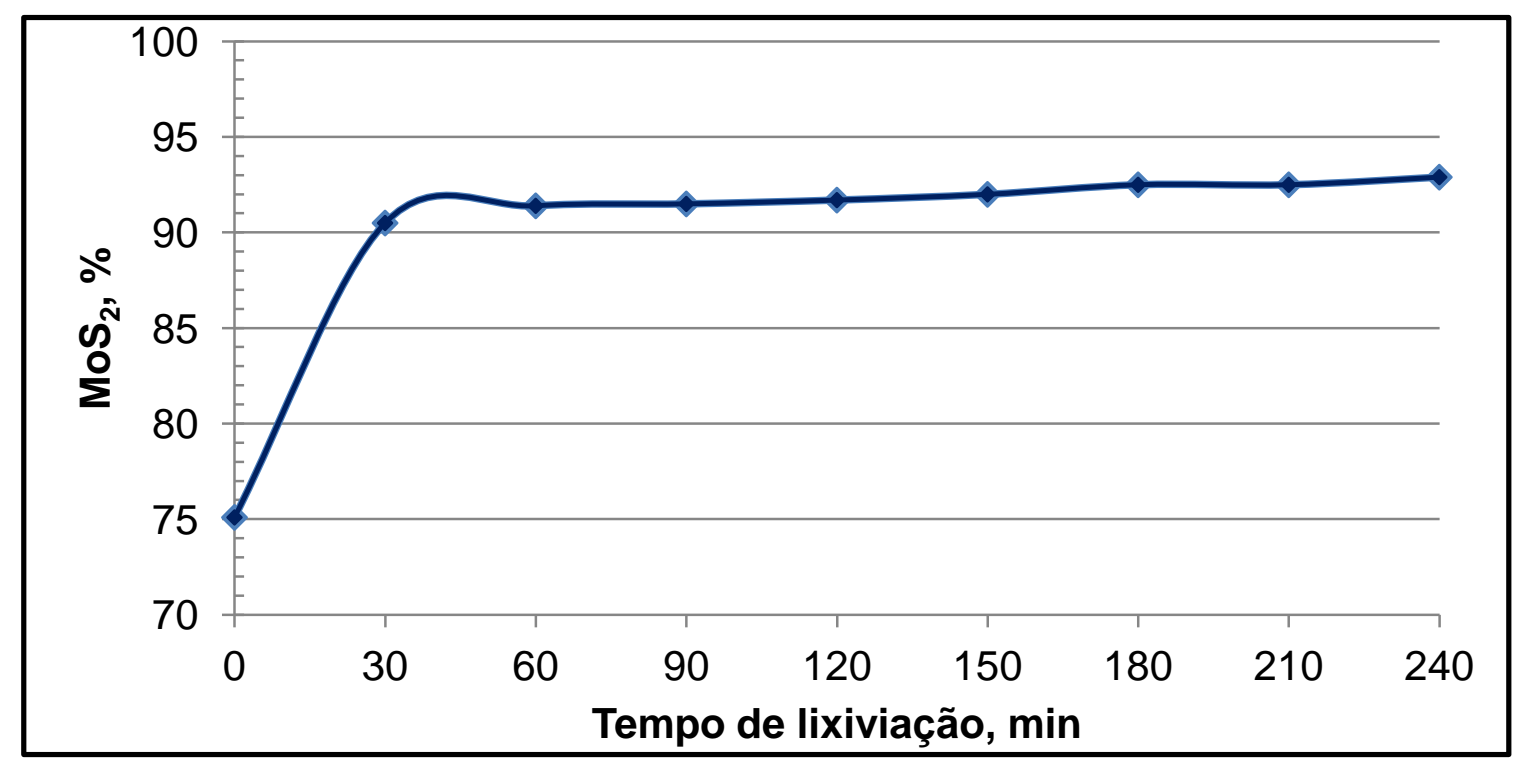

Figura 6.40 - Curva de purificação da molibdenita por lixiviação com HF (5\% p/v) 
A análise química do concentrado de molibdenita após lixiviação fluorídrica está contida na Tabela 6.10.

Tabela 6.10 - Análise química do concentrado de molibdenita lixiviado

\begin{tabular}{|c|c|c|c|c|c|c|c|c|}
\hline $\mathrm{Na}_{2} \mathrm{O}$ & $\mathrm{MgO}$ & $\mathrm{Al}_{2} \mathrm{O}_{3}$ & $\mathrm{SiO}_{2}$ & $\mathrm{~K}_{2} \mathrm{O}$ & $\mathrm{CaO}$ & $\mathrm{Fe}_{2} \mathrm{O}_{3}$ & $\mathrm{MoS}_{2}$ & $\mathrm{Bi}_{2} \mathrm{O}_{3}$ \\
\hline $\mathrm{nd}^{*}$ & 1,40 & 1,90 & 2,40 & 0,46 & 0,20 & 0,51 & 92,9 & 0,15 \\
\hline
\end{tabular}

Estudo semelhante realizado por Kumar et al. (2006), utilizando uma mistura de ácidos (fluorídrico e clorídrico) na temperatura de $130^{\circ} \mathrm{C}$, mostrou que foi possível atingir um teor de $95 \% \mathrm{MoS}_{2}$. No mesmo estudo, utilizando-se, porém, o processo de lixiviação sobre pressão em autoclave ( 2 horas a $120^{\circ} \mathrm{C}$ ) foi possível produzir um concentrado com teores de $97,8 \% \mathrm{MoS}_{2}$, adequado para uso direto na produção de lubrificantes ou de carbeto de molibdênio $\left(\mathrm{Mo}_{2} \mathrm{C}\right)$. 


\section{CONCLUSÕES}

No ano de 2012, a balança comercial brasileira para a cadeia do molibdênio (bens primários, semimanufaturados e manufaturados e compostos químicos) foi caracterizada por um déficit de aproximadamente US\$162 milhões.

A região de Campo Formoso, BA, é a única produtora de concentrado de molibdenita no país, com uma produção artesanal em torno de 5 t/ano. $O$ atual preço do molibdênio no mercado internacional (US\$37,15/kg $\mathrm{MoO}_{3}$ ) incentiva e valoriza a busca por essa commoditie mineral. $\mathrm{O}$ concentrado de molibdenita produzido em Campo Formoso, contém $78,4 \%$ de $\mathrm{MoS}_{2}$ e é comercializado por $\mathrm{R} \$ 25,00 / \mathrm{kg}(\sim 12$ US\$/kg).

A análise química dos concentrados de molibdenita (Tabela 6.4) apresentou baixo teor de $\mathrm{MoS}_{2}$ e teores elevados de $\mathrm{MgO}$ e $\mathrm{SiO}_{2}$, indicativos da presença de talco, flogopita, clorita e clinocloro. A presença de contaminantes implica em um concentrado de baixo valor agregado.

Tabela 6.4 - Análise química dos concentrados de molibdenita

\begin{tabular}{lccccccccc}
\hline & $\mathrm{Na}_{2} \mathrm{O}$ & $\mathrm{MgO}$ & $\mathrm{Al}_{2} \mathrm{O}_{3}$ & $\mathrm{SiO}_{2}$ & $\mathrm{~K}_{2} \mathrm{O}$ & $\mathrm{CaO}$ & $\mathrm{Fe}_{2} \mathrm{O}_{3}$ & $\mathbf{M o S}_{2}$ & $\mathrm{Bi}_{2} \mathrm{O}_{3}$ \\
\hline Conc. 3X & 0,15 & 3,90 & 4,10 & 10,0 & 1,50 & 0,43 & 2,40 & $\mathbf{7 7 , 3}$ & 0,15 \\
Conc. MM & 0,19 & 2,90 & 2,30 & 6,00 & 0,91 & 0,43 & 2,30 & $\mathbf{8 4 , 5}$ & 0,14 \\
Conc. ITA & 0,23 & 4,40 & 4,70 & 11,1 & 2,00 & 0,31 & 2,60 & $\mathbf{7 4 , 4}$ & 0,14 \\
\hline
\end{tabular}

O estudo de liberação indicou que a molibdenita encontra-se totalmente liberada dos minerais de ganga na granulometria de $295 \mu \mathrm{m}$. O minério tem um valor para o work índex de Bond $(W /)$ de 8,35 kWh/t curta.

Os estudos fundamentais de separabilidade do sistema molibdenita/talco mostraram que:

- a redução da flotabilidade é função da granulometria dos minerais e consequente aumento da área superficial, devido à diminuição da relação faces:bordas; tanto a molibdenita quanto o talco possuem superfícies anisotrópicas, onde as faces têm características hidrofóbicas (devido ao rompimento de ligações de van der Walls) e as bordas características hidrofílicas (devido ao rompimento de ligações covalentes);

- a flotabilidade da molibdenita sem o uso de qualquer depressor em função do $\mathrm{pH}$ é influenciada e reduzida na região alcalina, devido à presença de cargas elétricas contidas nas bordas da molibdenita, originadas da oxidação e hidrólise do 
$\mathrm{MoO}_{3}$ a $\mathrm{HMoO}_{4}{ }^{-}$e $\mathrm{MoO}_{4}{ }^{2-}$; por outro lado, a variação do $\mathrm{pH}$ não exerce efeito depressor sobre a superfície do talco, mantendo estável sua hidrofobicidade natural e, consequentemente, sua flotabilidade;

- o uso da dextrina, polímero não iônico, como depressor propicia uma janela de separabilidade de $68 \%$ quando utilizado em solução de 10 ppm e pH 8; estudos complementares da medição do ângulo de contato da molibdenita em diferentes concentrações de dextrina confirmaram a redução da hidrofobicidade do mineral;

- o uso do quebracho, polímero não iônico, como reagente depressor propicia uma janela de separabilidade de $63 \%$ quando utilizado em solução de 50 ppm e pH 8; estudos complementares da medição do ângulo de contato da molibdenita em diferentes concentrações de quebracho confirmaram a redução da hidrofobicidade do mineral;

- o ângulo de contato medido pelo método de ascensão capilar para o mineral talco não foi alterado pelos depressores dextrina e quebracho, nas concentrações e $\mathrm{pH}$ em que propiciaram janelas de separabilidades;

- a ação da dextrina e do quebracho na superfície da molibdenita afetou o potencial zeta para regiões de menor eletronegatividade, possivelmente devido a um deslocamento do plano de Stern; já a ação desses depressores na superfície do talco promoveu uma ação contrária, deslocando a curva de potencial zeta para regiões mais eletronegativas.

Nos ensaios de flotação em bancada, simulando um circuito com cinco etapas de limpeza, foi possível obter concentrado de molibdenita com 93,4\% de $\mathrm{MoS}_{2}$, utilizando-se dextrina como depressor, na dosagem de $100 \mathrm{~g} / \mathrm{t}$. Esse concentrado final purificado atende aos requisitos exigidos pelo comércio internacional.

Nos ensaios de purificação do concentrado de molibdenita, produzido em Campo Formoso, por lixiviação fluorídrica, foi produzido um bissulfeto de molibdênio $\left(\mathrm{MoS}_{2}\right)$ com $92,9 \%$ de pureza. No entanto, esse produto não pode ser considerado grau lubrificante, pois é necessária uma pureza mínima de $98 \% \mathrm{MoS}_{2}$.

No presente trabalho ficou demonstrada a importância dos estudos fundamentais realizados para a identificação de janelas de separabilidade entre os minerais molibdenita e talco. As condições experimentais determinadas na microflotação (concentrações e dosagens dos reagentes) puderam ser ajustadas, com êxito, para os ensaios de flotação em bancada, proporcionando o enriquecimento mineral de 1,24 vezes, em termos de $\mathrm{MoS}_{2}$. 
O escalonamento e utilização das condições operacionais determinadas nesse trabalho poderão auxiliar na melhoria do processo produtivo de molibdenita de Campo Formoso, contribuindo com a agregação de valor àquele produto $e$ proporcionando oportunidade da sua comercialização e aplicação mais nobre em alguns setores industriais.

Este trabalho não encerra todo o ciclo de purificação do concentrado de molibdenita produzido na região de Campo Formoso, BA. Investigações complementares ao presente estudo necessitam e devem ser realizadas, a saber:

- estudos de purificação do concentrado de molibdenita por flotação em bancada, utilizando-se quebracho como depressor da molibdenita;

- estudos de purificação do concentrado de molibdenita por flotação em bancada, em meio alcalino, utilizando-se cal hidratada, soda cáustica ou silicato de sódio como reguladores de $\mathrm{pH}$;

- estudos de refino, por lixiviação ácida, do concentrado de molibdenita purificado por flotação, utilizando ácidos inorgânicos em diferentes concentrações e temperaturas, de forma a obter um bissulfeto de molibdênio grau lubrificante ( $>98 \%$ $\left.\mathrm{MoS}_{2}\right)$. 


\section{REFERÊNCIAS BIBLIOGRÁFICAS}

ABDEL-REHIM, A.M. Thermal analysis and $x$-ray diffraction of roasting of egyptian molybdenite. In: Journal of Thermal Analysis and Calorimetry. v. 57, p. 415-431, 1999.

ABREU, S.F. Recursos Minerais do Brasil. São Paulo: v. 2, p. 568- 569, 1973.

ANUÁRIO ESTATÍSTICO. Brasília: Secretaria de Geologia, Mineração e Transformação Mineral. Ministério de Minas e Energia, 2009.

ANUÁRIO MINERAL BRASILEIRO. Brasília: DNPM, v. 34, 2006.

ARAUJO, A. C. et al. A flotação de minérios de ferro. In: CHAVES, A.P., Teoria e prática do tratamento de minérios: Flotação: o estado-da-arte no brasil. São Paulo: Signus, v. 4, p. 317-29, 2006.

ARBITER, N., FUJII, Y., HANSEN, B.; RAJA, A. Surface properties of hydrophobic solids. AICHE Symposium Series, v. 150, n. 71, p. 176-182. 1975.

BALTAR, C.A.M. Flotação no Tratamento de Minérios. 2. ed. Recife: UFPE, 2010.

BARBATO, C.N.; SAMPAIO, J.A. Tratamento de Minérios: Práticas Laboratoriais. Rio de Janeiro: SAMPAIO, J.A.; FRANÇA, S.C.A.; BRAGA, P.F.A., p. 179-189, 2007.

BARBOSA, et al. Mineração Metalurgia: Projeto tungstênio-molibdênio no Rio Grande do Norte e Paraíba. n. 293, p. 201-202, 1969.

BARBOSA, R.L.M.; GUSMÃO, A.M. Perfil Analítico do Molibdênio. Brasília: DNPM, Boletim n. 52, 1980.

BEATTIE, D.A. et al. Influence of adsorbed polysaccharides and polyacrylamides on talc flotation. International Journal of Mineral Processing, v. 78, p. 238-249, mar. 2006.

BEATTIE, D.A. et al. The effect of polysaccharides and polyacrylamides on the depression of talc and the flotation of sulphide minerals. Brisbane: Elsevier Journal Minerals Engineering, v. 19, p. 598-608, 2006.

BEAUSSART, A. et al. Adsorption of modified dextrins on molybdenite: AFM imaging, contact angle and flotation studies. In: Journal of Colloid and Interface Science. n. 368, p. 608-615, 2012. 
BEAUSSART, A. et al. Evolution of carboxymethyl cellulose layer morphology on hydrophobic mineral surfaces: Variation of polymer concentration and ionic strength. In: Journal of Colloid and Interface Science. v. 346, p. 303-310, 2010.

BENAMEUR, M.M. et al. Visibility of dichalcogenide nanolayers. v. 22, n. 12 , 2011.

BLOSSOM, J.W. A Chapter from Mineral Facts and Problems: Molybdenum. United States: Bureau of Mines, 1985.

BLOSSOM, J.W. Metal Prices in the United States through 1998: Molybdenum. Disponível em: <http://minerals.usgs.gov/minerals/pubs/metal prices/>.

BRAGA, P.F.A. Desenvolvimento de process,o para 0 aproveitamento do feldspato contido em finos de pedreira de nefelina sienito. 1999. Dissertação (Mestrado) - Escola Politécnica da Universidade de São Paulo. São Paulo: Departamento de Engenharia de Minas, 1999.

BRUM, M.C. Remoção de ácido húmico da água por precipitação e flotação com a utilização de surfatantes catiônicos. 2005. Dissertação (Mestrado) Programa de Engenharia Metalúrgica e de Materiais, Universidade Federal do Rio Janeiro, Rio de Janeiro, 2005.

BULATOVIC, S.M. Handbook of Flotation Reagents: Chemistry, Theory and Practice, Flotation of Sulfide Ores, v. 1. Oxford: Elsevier, 2007.

BULATOVIC, S.M. Use of organic polymers in the flotation of polymetallic ores: a review. Ontario: Elsevier Journal - Minerals Engineering, v. 12, n. 4, p. 341-354, 1999.

CARNAVALE RESOURCES. MOLYBDENUM PROJECT IN BRAZIL. Carnavale successfully completes initial exploration program at Frei Martinho: Disponível em: $<$ http://www.carnavaleresources.de/public/news.asp?c=41\&sid=2\&mm=22\&msub=30 \&lid=2\&mid=1310/>. Acesso em: 08 abr. 2011.

CASTRO, F.H.B.; HOCES, M.C. Influence of Quebracho and Sodium Silicate on Flotation of Celestite and Calcite with Sodium Oleate. Granada: International Journal of Mineral Processing, v. 37, p. 283-298, 1993.

CASTRO, S.H.; CORREA, A. The effect of particle size on the surface energy and wettability of molybdenite. Vancouver: 1st UBC-McGill International Symposium on Processing of Hydrophobic Minerals and Fine Coal, CIM MET SOC, 1995.

CHANDER, S.; FUERSTENAU, D.W. On the natural floatability of molybdenite. Transactions AIME, v. 252, p. 62, 1972. 
CHANDER, S.; WIE, J.M.; FUERSTENAU, D.W. On the native floatability and surface properties of naturally hydrophobic solids, AIChE Symposium Series, v. 71, n. 150, p. 183-8, 1975.

CHAU, T.T. A review of techniques for measurement of contact angles and their applicability on mineral surfaces. In: Minerals Engineering, 22, 213-219, 2009.

CHAVES, A.P. Flotação de carvão de Santa Catarina (Região de Alto Metalúrgico). 1983. 142p. Tese (Doutorado) - Escola Politécnica, Universidade de São Paulo, São Paulo, 1983.

CHAVES, A.P. Flotação: o estado da arte no Brasil. Coleção teoria e prática no tratamento de minérios; v4. São Paulo, Signus Editora, 2006.

CHAVES, A.P.; LEAL FILHO, L.S.; BRAGA, P.F.A. Flotação, Capítulo 11. In: LUZ, A.B.; SAMPAIO, J.A.; FRANÇA, S.C.A. Tratamento de Minérios, 5a Edição. Rio de Janeiro, CETEM/MCTI, 2010.

CIRIBENI, V.H.A.; SARQUÍS P. E.; GONZÁLEZ, M. Estudio del Efecto Depresor de Reactivos Orgánicos Naturales en La Flotación de Sulfuros. San Juan: Universidad Nacional de San Juan, Instituto de Investigaciones Mineras. Conamet/Sam-Simposio Materia, 2002.

CLIMAX MOLYBDENUM. Ferromolybdenum. Disponível em: http://www.climaxmolybdenum.com/Products/Metallurgical/FerromolyDetail.htm>

Acesso em: 2011.

CLIMAX MOLYBDENUM. Molybdenum Disulfide, Datasheet. Disponível em: http://www.climaxmolybdenum.com/Products/Chemical/Chemical.htm>. Acesso em: 2011.

CLIMAX MOLYBDENUM. Molybdenum Oxide. Disponível em: http://www.climaxmolybdenum.com/Products/Metallurgical/MolyOxide.htm>. Acesso em: 2011.

CODELCO, Corporación Nacional del Cobre de Chile, Mina de Chuquicamata. Circuito de flotação de molibdênio (cortesia), 2009.

COSTA, J.L. Sumário Mineral: Molibdênio. Brasília: DNPM, v. 20, 2000.

COUTO et al. Garimpos de esmeralda de Carnaíba e Socotó, Bahia. In: Principais depósitos minerais do Brasil: gemas e rochas ornamentais. Brasília: DNPM, v. 4, cap. 15, p. 259-269, 1991.

DANA, H. Livros Técnicos e Científicos: Manual de Minerologia. 3 ed. Rio de Janeiro: Editoras S.A., 1971. 
DANTAS, J.O.C. Relatório Interno: Flotação da Molibdenita como Subproduto nas Minas de scheelita de Currais novos. Rio de Janeiro: CETEM, n. 48, 1981.

DERJAGUIN, B.V.; SHUKAKIDSE, N.D. Transactions IMM. 70, 569, 1960-61.

DONOSO, J.J.J. Mercado Internacional y Mineria del Molibdeno en Chile. Santiago: Comision Chilena Del Cobre, fev. 2010.

DONOSO, J.J.J. Mercado Internacional Del Molibden y la producción en Chile. Santiago: Comision Chilena Del Cobre, out. 2011.

EPSHTEYN, Y.; RISDON, T.J. Molybdenum disulfide in lubrificant applications: A review. India: National Lubrificating Grease Institute, 12th Lubricating Grease Conference, Chap. 28-30, jan. 2010.

FOGEL, R. Viver mais custa caro. [Entrevista a GASPAR, M.]. Revista Veja, Editora Abril, ed. 2211, n. 14, 6 de abr. 2011.

FOKKINK, L.G.J.; RALSTON, J. Colloids Surfaces. Australia: School of Chemical Technology, South Australian Institute of Technology, v. 36, Issue 1, p. 69-76, 1989.

FONTELES, H.R.N. Sumário Mineral: Molibdênio. Brasília: DNPM, v. 29, 2009.

FUERSTENAU, D.W.; HUANG, P. Interfacial phenomena involved in talc flotation and depression. Proceedings of XXII International Mineral Processing Congress, vol. 2, Cape Town, p. 1034-1043, 2003.

FUERSTENAU, M.C. Semi-Soluble Salt Flotation. In: Principles of Flotation. Ed. KING, R.P. South African Institute of Mining and Metallurgy, Johannesburg. Chapter 10, 1982.

FUERSTENAU, M.C.; LOPEZ-VALDIVIESO, A.; FUERSTENAU, D.W. Role of hydrolysed cátions in the natural floatability of talc. International Journal of Mineral Processing, v. 23, p. 161-170, 1988

FUERSTENAU, M.C.; SOMASUNDARAN, P. Flotation. In: Principles of Mineral Processing. Colorado: Fuerstenau, M. C; HAN, K. N., SME, chap. 8, 2003.

GAUDIN, A.; MIAW, H.L.; SPEDDEN, H.R. Proceedings $2^{\text {nd }}$ International Congress of Surface Activity. London: p. 202, 1957.

GHABBOUR, E.A.; DAVIES, G. (Editors) (2001). Humic Substances: Structures, Models and Functions. Cambridge, U.K.: RSC publishing. ISBN 978-0-85404-811-3, 2001. 
GOMES, J.I.A. Purificação de Pré-Concentrado de Molibdenita Através de Flotação. Rio de Janeiro: CETEM, n. 27/81, 1981.

GOMES, L.M.B. Controle Físico-Químico da Flotabilidade Natural do Talco pela Carboximetilcelulose. 1988. Dissertação (Mestrado) - Departamento de Engenharia Metalúrgica e de Materiais da COPPE - Universidade Federal do Rio Janeiro, 1988.

GOMES, L.M.B.; OLIVEIRA, J.F. The control of natural floatability of talc with carboxymethyl cellulose and aluminium chloride. In: Fine Particles Processing Flotation, 17th mt. Miner. Process. Congress, v. 2, sept. 1991.

GUSMÃO, A.M. Sumário Mineral: Molibdênio. Brasília: DNPM, v. 1, 1981.

GUSMÃO, A.M. Sumário Mineral: Molibdênio. Brasília: DNPM, v. 10, 1990.

HISCOX et al. Use of lignin sulphonate as moly depressant boosts recovery at Twin Buttes. In: Operating Handbook of Mineral Processing, apr.1975.

HUCH, R.O.; VALLES, P. Talc-Molybdenite Separation. United States Patent 3921810, 1975.

IMERYS. TALC the mineral. Disponível em http://www.imerystalc.com /content/corporate/abouttalc/Talc the mineral/Mineralogy \& morphology/index.php> . Acesso em: 12 nov 2012.

INFOMINE RESEARCH GROUP: Review of Molybdenum Market in the CIS. Disponível em: <http://www.infomine.ur>. Moscow: dec. 2006.

INFOMINE. Disponível em http://www.infomine.com/investment/metalprices/molybdenum-oxide/ >. Acesso em: 12 nov 2012.

IMOA. Molybdenum - folheto institucional com especificaçiões, BSC print. London: International Molybdenum Association Newsletter. 1998.

IMOA. Chemical applications of Molybdenum. London: International Molybdenum Association Newsletter. jul. 2005.

IMOA. Molybdenum - Uses, Consumption, Sources and Prices. London: International Molybdenum Association Newsletter. jan 2007.

IMOA. Molyreview. London: International Molybdenum Association Newsletter. jan 2009.

JARA, C.; CASTRO, S. Depresión de Molibdenta por Reactivos Floculantes. Chile: Departamento de Ingeniería Metalúrgica, Universidad de Concepción - IV Taller Internacional de Processamiento de Minerales, 2006. 
JIANG et al. A new approach for removing talc for upgrading molybdenite ores. Colorado: SME Annual Meeting, pp 99-126, 1-3 mar. 1999.

JONES, M.N.; BRYAN, N.D. Colloidal properties of humic substances. In: Advances in Colloid and Interface Science. v. 78, Issue 1, p. 1-48, 1998.

KELEBEK, S.; YORUK, S.; SMITH, G. W. Wetting Behavior of Molybdenite And Talc in Lignosulfonate/MIBC Solutions and Their Separation by Flotation. In: Separation Science and Technology, v. 36, p. 145-157, 2001.

KING, H.M. Talc: the softest mineral. Disponível em: <http://geology.com/minerals/talc.shtml>. Acesso em: 12 nov. 2012.

KUMAR, M. et al. Refining of a low-grade molybdenite concentrate. In: Hydrometallurgy. Elsevier, v. 86, p. 56-62, 2007.

KUSAKA, E.; AMANO, N.; NAKAHIRO, Y. Effect of hydrolysed aluminum (III) and chromium (III) cations on the lipophilicity of talc. In: International Journal of Mineral Processing. Elsevier, v. 50, p. 243-253, 1997.

LAI, R.W.M.; STONE, L.C.; RIMMASCH, B.E. Effect of humus organics on the flotation recovery of molybdenite. In: International Journal of Mineral Processing. Salt Lake City: 56th Colloid and Surface Science Symposium, v. 12, Issue 1-3, p. 163-172, 1984.

LASKOWSKI, J.S.;LIU,Q.; O'CONNOR, C.T. Current understanding of the mechanism of polysaccharide adsorption at the mineral/aqueous solution interfaces. In: International Journal of Mineral Processing, 84, p. 59-68, 2007.

LEJA, J. Surface Chemistry of Froth Flotation, Plenum Press, New York, 1982.

LIN, K.F.; BURDICK C.L. Polymeric Depressants. In: Reagents in Mineral Technology. New York: Somasundaran, P.; Moudgil, B.; Marcel Dekker Journal, Chapter 15, p. 471-483, 1988.

LINS, F.A.F. Concentração Gravítica, In: Tratamento de Minérios. Rio de Janeiro: LUZ, A.B., SAMPAIO, J.A.; FRANÇA, S.C.A.; CETEM/MCT, 5a edição, cap 7, 2010.

LIU, G. et al. Adsorption of polysaccharide onto talc. In: Minerals Engineering. v. 19, Issue 2, p. 147-153, 2006.

LOESBY, R.E. Molybdenum supply forecasting. In: Mining Engineering Magazine. jul. 2007.

LONDON METAL EXCHANGE. LME Molybdenum. Disponível em: <http://www.Ime.com/minormetals/molybdenum.asp>. Acesso em: 4 abr. 2011. 
LOPES, G.M. Flotação direta de minério de ferro. 2009. 175p. Dissertação (Mestrado) - Escola de Minas da Universidade Federal de Ouro Preto, Ouro Preto, 2009.

LÓPEZ-VALDIVIESO, A. et al. The heterogeneity of the basal plane of molybdenite: Its effect on molybdenite floatability and calcium ion adsorption. Santiago: 9th International Mineral Processing Conference, PROCEMIN, p.21-23, nov 2012.

MACHADO, F.B. et al. Enciclopédia Multimídia de Minerais. ISBN: 85-89082-11-3. Disponível em: <http://www.rc.unesp.br/museudpm>. Acesso em: 28 mar. 2011.

MALVERN. Zetasizer Nano Series - User manual. U.K.: Malvern Instruments Ltd., 2009.

MARTINS, M. Molhabilidade de Apatita e sua Influência na Flotação. 2009. 120p. Tese (Doutorado) - Escola Politécnica, Universidade de São Paulo, São Paulo, 2009.

MATHIEU, G.I.; BRUCE, R.W. Getting the talc out of molybdenite ores. In: Canadian Mining Journal. p. 75-77, jun. 1974.

MERCHANT, Molybdenum Market Review, Merchant Research \& Consulting Ltd. United Kingdom, jan 2011.

METALLURGICAL. Climax Molybdenum Company. Disponível em: $<$ http://www.climaxmolybdenum.com/Products/Metallurgical>. Acesso em: 07 abr. 2011.

METALS WEEK. Platts, The McGraw-Hill Companies, 30 aug. 2010. v. 81, Issue 35. Disponível em: <http://www.platts.com/Products/metalsweek/>. Acesso em: 06 abr. 2011.

MINERAL COMMODITY SUMMARIES: Molybdenum. USGS, 1995-2012. Disponível em: <http://minerals.usgs.gov/minerals/pubs/commodity/molybdenum/>.

MOLIBDENITA supera silício e grafeno na eletrônica. Inovação Tecnológica, 01 fev. 2011. Disponível em: <http://www.inovacaotecnologica.com.br /noticias/noticia. php?artigo=molibdenita-supera-silicio-grafeno-eletronica $>$. Acesso em: 31 mar. 2011.

MOLYBDENUM MARKET REVIEW. Merchant Research \& Consulting Ltd. United Kingdom: jan 2011.

MOLYBDENUM PRODUCTS. China Tungsten Online (Xiamen) Manu. \& Sales Corp. Disponível em: <http://www.molybdenum.com.cn/>. Acesso em: 7 abr. 2011. 
MOLYBDENUM. Luoyang City: Luomu Group - China Molybdenum Co., Ltda. Disponível em: <http://www.chinamoly.com/en/03products/detail mujingkuang.htm/>. Acesso em: 7 abr. 2011.

MONTE, M.B.M; PERES, A.E.C. Química de superfície na flotação, Capítulo 10. In: LUZ, A.B.; SAMPAIO, J.A.; FRANÇA, S.C.A. Tratamento de Minérios, 5a Edição. Rio de Janeiro, CETEM/MCTI, 2010.

MOREIRA, M.D.; SILVA, R.W.S. Esmeralda de Carnaíba, Bahia: Geologia e Desenvolvimento de Garimpo. In: Série Arquivos Abertos, Companhia Baiana de Pesquisa Mineral. Salvador, 2006.

MORRIS, G.E. The adsorption characteristics of polimeric depressants at the talc-water interface. 1996. Tese (Doutorado) - School of Chemical Technology, Faculty of Applied Science and Technology, University of South Australia, 1996.

NESI, J.R. Molibdênio. In: Sumário Mineral. Brasília: DNPM, v. 27, 2007.

NUNES, A. P. L.; PERES, A. E. C. Reagentes depressores de carbonatos: uma revisão. In: Série Tecnologia Mineral. Rio de Janeiro: CETEM/MCT, n. 89, 2011.

OLIVARES, G. Mercado Nacional e Internacional Del Molibdeno. Comision Chilena Del Cobre, ago. 2005.

OZKAN, A.; YEKELER, M. A new microcolumn flotation cell for determining the wettability and floatability of minerals. Journal of colloid and interface science. New York: Elsevier, n. 261, p.476-480, 2003.

PANTOJA-CASTRO, M.A.; GONZÁLEZ-RODRÍGUEZ, H. Study by infrared spectroscopy and thermogravimetric analysis of tannins and tannic acid. Revista Latinoamericana de Química. n.39 (3), p.107-112, 2011.

PARKINSON, G. Cyprus develops moly-talc separation float. In: Operating Handbook of Mineral Processing. New York: THOMAS, R., McGraw-Hill, Inc. v. 1, may 1976.

PAWLIK, M. Polimery dispersants for coal-water slurries. In: Colloids and Surfaces A: Physicochemical and Engineering Aspects, v. 266, Issues 1-3, p. 82-90, 2005.

PEARSE, M.J. An Overview of the Use of Chemical Reagents in Mineral Processing. In: Minerals Engineering, v. 18, p. 139-149, 2005.

PERES, A.E.C.; ARAÚJO, A.C. A flotação como operação unitária no tratamento de minérios. In: CHAVES, A.P. Teoria e Prática do Tratamento de Minérios, Flotação, v4. Editora Signus, p.444, 2006. 
PERES, A.E.C.; CORREA, M.I. Depression of iron oxides with corn starches. In: Minerals Enginnering, v.9, n. 12, p. 1227-1234, 1996.

PLANO NACIONAL DE MINERAÇÃO 2030. Brasília: Secretaria de Geologia, Mineração e Transformação Mineral, Ministério de Minas e Energia, 2010.

POLYAK, D.E. Molybdenum [Advance Release]. In: Minerals Yearbook. United States: U.S. Geological Survey, U.S. Department of the Interior, 2008.

RADISAVLJEVIC, B.; RADENOVIC, A.; BRIVIO, J. GIACOMETTI, V; KIS, A. Singlelayer $\mathrm{MoS}_{2}$ transistors. Nature Nanotechnology, 6, 147-150, 2011.

RATH, R.K.; LASKOWSKI, J.S.; SUBRAMANIAN, S. Interaction of guar gum with hydrophobic solids. In: 3rd UBC-McGill Bi-Annual International Symposium on Fundamentals of Mineral Processing held at the 38th Annual Conference of Metallurgists of CIM. Quebec: 1999.

RATH, R.K.; SUBRAMANIAN, S.; LASKOWSKI, J.S. Adsorption of Dextrin and Guar Gum onto Talc - A Comparative Study. In: Langmuir. v.13, p. 6260-6266, 1997.

RISDON, T.J. Properties of Molybdenum Disulfide. Climax Molybdenum Company, jan. 2003.

SANTOS, I.D. Utilização de ácido húmico como agente depressor da hematita na flotação de minério de ferro. 2006. Dissertação (Mestrado) - Programa de Engenharia Metalúrgica e de Materiais, Universidade Federal do Rio Janeiro, Rio de Janeiro, 2006.

SARQUÍS P.E. et al. Application of modified quebracho extrats to the coppermolybdenum separation. Argentina: Instituto de Investigaciones Mineras, Universidad Nacional de San Juan, 2008.

SIEBOLD, A.; WALLISER, A.; NARDIN, M.; OPPLIGER, M.; SCHULTZ, J. Capillary Rise for Thermodynamic Characterization of Solid Particle Surface of Solid Particle Surface, Journal of Colloid and Interface Science 186, 60-70 (1997).

SILVA, J.P.P. Mecanismo de ação do silicato de sódio como depressor em flotação. Dissertação (Mestrado) - Programa de Pós-Graduação em Engenharia Mineral, Universidade Federal de Pernambuco, Recife, 2011.

SISTEMA ALICE-WEB. Ministério do Desenvolvimento, Indústria e Comércio Exterior. Disponível em: <http://aliceweb.desenvolvimento.gov.br/>. 2012.

SOMASUNDARAN, P.; MOUDGIL, B.M. Reagentes in Mineral Technology. Surfactants Science Series. New York: v. 27, 1988. 
SOUTHERN COPPER GRUPO MEXICO. Disponível em: $<$ http://www.southerncoppercorporation.com/ESP/opinte/Pages/PGProductos.aspx>. Acesso em: 06 abr. 2011.

SPECIALTY MINERALS. Disponível em: <http://www.specialtyminerals.com/ourminerals/what-is-talc/>. Acesso em: 12 nov 2012.

SPEDDEN, H.R. et al. Processing Molybdenite Concentrated by an Acid BakeLeach-Flotation Method. San Francisco: SME Preprint 71B75, AIME Annual Meeting, feb. 1971.

STIEFEL, E. I. Molybdenum and Molybdenum Alloys. Kirk-Othmer Encyclopedia of Chemical Technology, 2001.

TABARES, J.O. et al. Surface properties and flotability of molybdenite. Proceedings of 2006 China-Mexico Workshop on Minerals Particle Technology. San Luis Potosi, Mexico. 2006.

UNITAN SAICA. Sinônimo de tanino vegetal. Disponível em: <http://www.unitan.net/>. Acesso em: 12 abr. 2012.

VIEGAS, T.Y; MONTE, M.B.M. Estudo de Ângulo de Contato da Apatita e Calcita na Presença de Lauroyl Sarcosinato de Sódio pelo Método de Ascensão Capilar. Anais da XX JIC, PBIC/CETEM/MCTI. Rio de Janeiro, 2012.

VINCENT, J.D.; SHIRLEY, J.F. Section 16 Molybdenum. In: SME Mineral Processing Handbook. New York: WEISS, N.L., v. 2, 1985.

VOGT, C. Fronteiras e desafios do conhecimento. In: Revista USP. São Paulo: n. 59, p. 203-223, set./nov., 2003.

WIE, J.M.; FUERSTENAU, D.W. International Journal of Mineral Process. v. 1, n. $17,1974$.

WILSON, M. Molybdenum Market Outlook In: VP Marketing and Sales International Titanium Association Conference. p. 21-24, sep. 2008. 